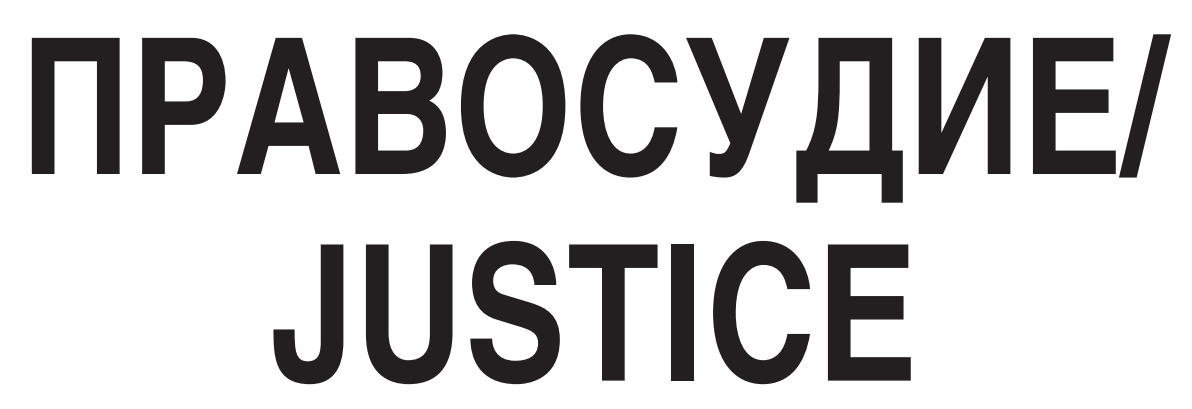

2021

TOM 3, № 1
2021

Vol. 3 , no. 1
Научно-практический журнал

Учредитель и издатель:

Российский государственный

университет правосудия
Scientific and Practical Journal

Founder and publisher:

Russian State University of Justice
Издается с сентября 2019 года

Периодичность издания -4 раза в год
Published since September 2019

Publication frequency: quarterly

http://justice.study 
Научный журнам "Правосудие/Justice" публикует оригинальные, соответствующие установленным требованиям статьи, в которых исследуются наиболее значимые для отечественной и зарубежной юридической науки и философии проблемы, относящиеся к следующим направлениям: право, глобализация и правосудие, современные правопонимание и правовые доктрины, цифровизация и право, судопроизводство, философия, философия права, право и язык.

С целью экспертной оценки каждого поступающего в редакцию материала осуществляется научное рецензирование. Все рецензенты являются признанными специалистами по тематике рецензируемых материалов. Рецензии хранятся в редакции в течение пяти мет. Редакция журнала направляет копии рецензий при поступцении соответствующего запроса в Министерство науки и высшего образования Российской Федерации.

Журнал следует стандартам редакционной этики согласно международной практике редактирования, рецензирования, издательской деятельности и авторства научных публикаций и рекомендациям Комитета по этике научных публикаций.

Наименование и содержание рубрик журнала соответствуют отраслям науки и группам специальностей научных работников согласно Номенклатуре специальностей научных работников:

12.00.00 Юридические науки

09.00.00 Фимософские науки

Журнал зарегистрирован в Федеральной службе

по надзору за соблюдением законодательства в сфере связи, информационных технологий и массовых коммуникаций (Роскомнадзор)

Свидетельство о регистрации: ПИ № ФС77-76078 от 24 июня 2019 г.

Переводчик И. А. Клепальченко

Научный редактор $\Lambda$. Б. Архипова

Корректор К. В. Чегумова

Компьютерная верстка Г. С. Гордиенко

\section{Адрес редакииu:}

117418, г. Москва, ум. Новочеремушкинская, д. 69 Тем.: +7(495) 332-51-49; +7(495) 332-51-19

При перепечатке и цитировании ссылка на журнал "Правосудие/Justice" обязательна.

Полное или частичное воспроизведение в СМИ материалов, опубликованных в журнале, допускается только с разрешения редакции

ГУП МО «Коломенская типография»

Подписано в печать 25.03.2021

Формат $70 \times 100 / 16$

Объем 18,2 усл. печ. $\Lambda$.

Тир. 300 
The peer reviewed, academic and scientific journal "Pravosudie/Justice" publishes original articles that explore the most important issues concerning both domestic and foreign jurisprudence and philosophy. They correspond to advanced requirements, including rights, globalisation and justice, modern legal thinking and legal doctrines, digitalization and law, justice, philosophy, philosophy of law, and law and language.

Each article submitted to the editorial board material is subject to a scientific and academic review by an expert peer reviewer. All peer reviewers are top-ranked experts on the subject of materials they review. Reviews are kept in the editorial office for five years. When requested by the The Ministry of Science and Higher Education of the Russian Federation, the editorial staff sends them copies of the reviews that were made.

The journal follows the standards of editorial ethics in accordance with international practice of editing, reviewing, publishing and authoring scientific publications and the recommendations of the Committee on Publication Ethics (COPE).

The name and content of the journal headings correspond to the branches of science and groups of specialties of scientific workers in accordance with the Nomenclature of specialties of scientific workers:

12.00.00 Jurisprudence

09.00.00 Philosophical Sciences

The Journal is registered in the Federal Service for Supervision in the Sphere of Communications, Information Technology and Mass Media (Roskomnadzor)

Certificate: ПИ № ФС77-76078 24.06.2019

Translator I. A. Klepal'chenko

Scientific editor L. B. Ahkhipova

Proof-reader K. V. Chegulova

Computer layout G. S. Gordienko

Postal adress:

69 Novocheremushkinskaya ul., Moscow 117418, Russian Federation

Tel.: +7(495) 332-51-49; +7(495) 332-51-19

When reprinting or quoting, the reference to the journal "Pravosudie/Justice" is necessary.

No part of this publication may be reproduced

without the prior written permission of the publisher

Printing House: "Kolomenskaya Tipografiya"

Signed to print 25.03.2021

Sheet size $70 \times 100 / 16$

Conventional printed sheets 18,2

Number of copies 300

Pravosudie/Justice. Vol. 3, no. 1. 2021 


\section{ГАавный редактор}

Корнев Виктор Николаевич (г. Москва, Россия), доктор юридических наук, профессор, заведующий кафедрой конституционного права имени Н. В. Витрука Российского государственного университета правосудия

\section{Редакционная коммегия}

Амекси Роберт (г. Кимь, Германия), профессор, доктор, почетный доктор, доктор публичного права и философии права, ведущий профессор юридического факультета Кицьского университета имени Христиана Альбрехта

Бамагер Камьехон Франциско (г. Гранада, Испания), профессор конституционного права Университета Гранады

Бородинова Татьяна Геннадьевна (г. Краснодар, Россия), доктор юридических наук, доцент, заведующий кафедрой уголовно-процессуального права Северо-Кавказского филиала Российского государственного университета правосудия

Вударски Аркадиуш (г. Франкфурт-на-Одере, Германия), профессор польского и европейского частного права и сравнительного права Европейского университета Виадрина; заведующий кафедрой гражданского права, гражданского процесса и сравнительного частного права Зеленогурского университета (Польша, г. Зелена Гура)

Дорская Амександра Андреевна (г. Санкт-Петербург, Россия), доктор юридических наук, профессор, заместитель директора по научной работе, заведующий кафедрой общетеоретических правовых дисциплин Северо-Западного филиала Российского государственного университета правосудия

Ершов Валентин Валентинович (г. Москва, Россия), доктор юридических наук, профессор, заслуженный юрист Российской Федерации, заслуженный деятель науки Российской Федерации, академик Российской академии естественных наук, президент Российского государственного университета правосудия

Киейзик Мимианна-Божена (г. Земена-Гура, Помьша), Dr hab., ординарный профессор Института философии Зеленогурского университета

Кэмер Аоренц (г. Бремен, Германия), доктор права, профессор юридического факумьтета Бременского университета

Марочкин Сергей Юрьевич (г. Тюмень, Россия), доктор юридических наук, профессор, директор Института государства и права Тюменского государственного университета, заскуженный юрист Российской Федерации

Монжамь Пьер-Ив (г. Тур, Франция), доктор публичного права, профессор Университета Франсуа Рабле

Никомич Драган К. (г. Ниш, Сербия), доктор юридических наук, профессор, заведующий кафедрой историко-юридических наук юридического факультета Государственного университета

Огцезнев Витаций Васицьевич (г. Томск, Россия), доктор философских наук, профессор кафедры теории и истории права и государства Западно-Сибирского филиала Российского государственного университета правосудия

Фаргиев ибрагим Аюбович (г. Магас, Россия), доктор юридических наук, профессор, заслуженный юрист Российской Федерации, Председатель Верховного суда Республики Ингушетия

Фролова Елизавета Амександровна (г. Москва, Россия), доктор юридических наук, доцент, профессор кафедры теории государства и права и политологии юридического факультета МГУ имени М. В. Аомоносова

Химма Кеннет Эйнар (г. СиэтА, США), доктор права, профессор юридического факуиьтета Вашингтонского университета 


\section{Editor-in-Chief}

Viktor N. Kornev (Moscow, Russian Federation), Dr. Sci. (Law), Professor, Head of the Vitruk Constitutional Law Department of the Russian State University of Justice

\section{Editorial board}

Robert Alexy (Kiel, German), Prof. Dr. Dr. h.c. mult., Senior Professor of the Law Department of the Christian Albrecht University of Kiel

Francisco Balager Callejón (Granada, Spain), Professor of Constitutional Law of the University of Granada

Tatiana G. Borodinova (Krasnodar, Russian Federation), Dr. Sci. (Law), Associate Professor, Head of the Criminal Procedural Law Department of the North Caucasian Branch of Russian State University of Justice

Arkadiusz Wudarski (Frankfurt am Oder, Germany), Professor of Polish and European Private Law and Comparative Law at the European University Viadrina; Head of the Civil Law, Civil Procedure and Comparative Private Law Department, University of Zielona Góra (Zielona Góra, Poland).

Alexandra A. Dorskaya (Saint Petersburg, Russian Federation), Dr. Sci. (Law), Professor, Deputy Director, Head of the General Theoretical Legal Disciplines Department of the North-West Branch of the Russian State University of Justice

Valentin V. Ershov (Moscow, Russian Federation), Dr. Sci. (Law), Professor, Honored Lawyer of the Russian Federation, Honored Worker of Science of the Russian Federation, Academician of the Russian Academy of Natural Science, President of the Russian State University of Justice

Lilianna-Bożena Kiejzik (Zielona Góra, Poland), Dr hab., Full Professor, Institute of Philosophy, University of Zielona Góra

Lorenz Kaehler (Bremen, Germany), PhD in Law, Professor, the University of Bremen School of Law

Sergey Yu. Marochkin (Tyumen', Russian Federation), Dr. Sci. (Law), Professor, Director of the Institute of State and Law, Tyumen' State University, Honored Lawyer of the Russian Federation

Pierre-Yves Monjal (Tours, France), PhD in Public Law, Professor of the Francois Rabelais University

Dragan K. Nikolić (Niš, Serbia), PhD in Law, Professor, Head of the History and Law Department of Law Department of the State University

Vitaly V. Ogleznev (Tomsk, Russian Federation), Dr. Sci. (Philosophy), Professor of the Theory and History of Law and State Department of the West Siberian Branch of the Russian State University of Justice

Ibragim A. Fargiyev (Magas, Russian Federation), Dr. Sci. (Law), Professor, Honored Lawyer of the Russian Federation, Chairman of the Supreme Court of the Republic Ingushetia

Elizaveta A. Frolova (Moscow, Russia), Dr. Sci. (Law), Associate Professor, Professor of the Theory of State and Law and Political Science Department, Faculty of Law, M. V. Lomonosov Moscow State University

Kenneth E. Himma (Seattle, USA), PhD in Law, Professor of the University of Washington School of Law 


\section{РЕДАКЦИОННАЯ СТАТЬЯ}

Корнев В. Н. Авторитетные зарубежные журналы: тематика исследований.... 8

\section{ОРИГИНАЛЬНЫЕ СТАТЬИ}

\section{СОВРЕМЕННОЕ ПРАВОПОНИМАНИЕ}

Ершов В. В. Правопонимание, правотворчество и правореализация

(на англ. яз.)

\section{ПРАВОСУДИЕ}

От редакции. Существует ли судейское нормотворчество?

Балагер Кальехон Ф. Нормотворческая функция конституционных

решений.

Гарбатович Д. А. Социальная значимость регламентации непреступных уголовно-правовых деяний (на англ. яз.).

Бурмистрова С. А. Способы защиты публично-правовых интересов в цивилистическом процессе

\section{ИСТОРИЯ ГОСУДАРСТВА И ПРАВА}

Поскребнев М. Е. Институт отвода судьи в гражданском процессе:

исторический аспект.

ОТРАСЛИ ПРАВА. ИНСТИТУТЫ ПРАВА

Халиков И. А. Признаки субъекта преступления, предусмотренного

статьей 243.2 Уголовного кодекса Российской Федерации

Грибов Н. Д. Обязанности участников корпорации.

Семиходский А. Г. Криминалистические базы данных геномной информации: международный опыт и возможность его применения в Российской Федерации

\section{ПЕРЕВОДЫ}

ОТРАСЛИ ПРАВА. ИНСТИТУТЫ ПРАВА

Вударски А. В поисках эффрективного правового регулирования европейской ипотеки 


\section{EDITORIAL}

V. N. Kornev. Reputable foreign journals: research topics

\section{ORIGINAL PAPERS}

MODERN UNDERSTANDING OF LAW

V. V. Ershov. Legal understanding, law making and law implementation

(In Eng.)

JUSTICE

From the editorial staff. Is there a judicial law-making? ............................... 31

F. Balaguer Callejón. Normative function of constitutional decisions

$D$. A. Garbatovich. The social significance of the regulation of non-criminal acts in the criminal law (In Eng.)

S. A. Burmistrova. The measures to protect public legal interests in the civil process.

HISTORY OF THE STATE AND LAW

M. E. Poskrebnev. The Institution of Recusal of Judges in Civil Proceedings:

Historical Aspect

BRANCHES AND INSTITUTIONS OF THE LAW

I. A. Khalikov. The signs of the subject of a crime under article 243.2

of the Criminal code of the Russian Federation

N. D. Gribov. Obligations of corporation members

A. G. Semikhodskii. Forensic DNA databases: International experience and the possibility of its application in the Russian Federation

TRANSLATIONS

BRANCHES AND INSTITUTIONS OF THE LAW

A. Wudarski. In search of effective legal regulation of European mortgage 184 


\section{Авторитетные зарубежные журналы: тематика исследований}

$\mathbf{Y}_{\text {r }}$ итателям журнала "Правосудие/Justice» будет интересно ознакомиться с проблематикой публикаций зарубежных комлег в ведущих иностранных журналах. Мы не беремся проанализировать содержание всех наиболее значимых англоязычных журналов по праву - это непосимьный труд, ибо таких научных изданий насчитывается около 150. В настоящем обзоре представцено краткое содержание и проанализированы статьи, которые были опубликованы за 2020 - начало 2021 г. в таких университетских изданиях, как "Cambridge Law Journal", "Harvard Law Review», "Minnesota Law Review», "Oxford Journal of Legal Studies".

Все статьи можно сгруппировать по нескольким направлениям исследований. Первая группа статей - это те статьи, которые посвящены вопросам правового регулирования в условиях пандемии COVD-19, имеющей по своим последствиям планетарное значение.

Весьма показатецьными в этом смысле явцяются публикации на страницах журнала "Minnesota Law Review" - "Распознавание лии и четвертая поправка", "Как пандемия COVID-19 изменила и должна изменить американскую систему безопасности». В первой статье ее автор Эндрю

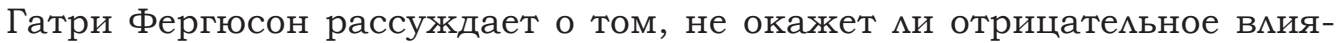

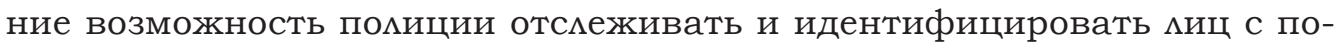
мощью сетевых камер набцюдения. Автор высказывает серьезную обеспокоенность тем, что в результате применения камер слежения могут быть нарушены права человека на свободу и безопасность мичности. В этом аспекте и исследуется проблема, насколько введенная система видеонаблюдения дмя распознавания миц соответствует Конституции США, и в частности Четвертой поправке, которая призвана ограничить полицейскую власть и правительственный произвоц в деле мощной и всепроникающей технологии слежки. По мнению ученого, современная доктрина и конституционная теория предмагают меньше мер дмя защи-

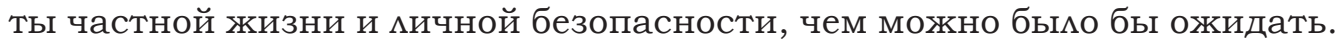

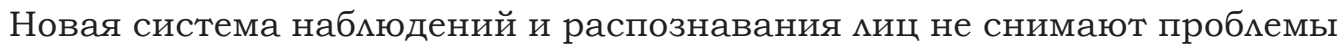
частоты ошибок, в том числе и основанных на расовых предубеждениях. На основе анализа дем, рассмотренных Верховным Судом США, которые касаются применения цифровых технологий, автором формумируются предложения по совершенствованию доктрины и правовому

(C) Корнев В. Н., 2021 
регулированию Четвертой поправки применительно к современным усмовиям.

В статье "Как пандемия COVID-19 изменила и должна изменить американскую систему безопасности» ее авторы Эндрю Хэммонд, Ариэль Юроу Клейман и Габриэль Шеффцер отмечают, что пандемия COVID-19 вызва$\Lambda$ беспрецедентный шок в Соединенных Штатах и во всем мире. Неясно, как домго продиится этот эпидемиологический и экономический кризис, и трудно оценить масштабы и направцение изменений в американской жизни, вызванных этими кризисами. При этом бесспорно, что пандемия оказывает значительное дав ение как на способность американцев удовметворять основные потребности, так и на способность правительства оказывать им помощь. Федеральные, государственные и местные органы власти, указывают авторы, приняли различные меры дмя развертывания существующих программ социальной защиты, таких как введение продовольственных талонов, налоговые кредиты и страхование от безработицы, чтобы удовлетворить всплеск потребностей. В статье отмечается, что на данном этапе кризиса следует: а) опредецить, каким образом пандемия подпитывает и усугубцяет расовое и экономическое неравенство в Америке; б) детально проанализировать реакцию правительства; в) рассмотреть изменения в результате нынешнего кризиса и г) решить, как правительство в будущем домжно строить программы социального обеспечения дмя удовлетворения потребностей всех американцев в ближайшие годы. Авторы этого эссе попытались сделать так, чтобы раскрытие и аргументация этих четырех тезисов были понятны и полезны как дмя юристов, так и дмя всего общества.

Следует отметить, что и на страницах журнала "Правосудие/Justice» проблемы, связанные с пандемией COVID-19, также получили свое освещение в ряде статей.

Вторая группа публикаций посвящена исследованию специальных тем - вопросов правового регулирования межрасовых и межнациональных отношений. В качестве примера приведем статьи, опубликованные в американском журнале "Harvard Law Review".

Так, в статье профессора Рэндамла $\Lambda$. Кеннеди "Расовая критика юридической науки" анализируются труды, в которых исследовано вмияние расовых различий на распредемение научного влияния и престижа в юридической науке. Автор утверждает, что эти труды формумируют два взаимосвязанных тезиса: первый - тезис об исключении - это вера в то, что интемлектуальный вклад цветных ученых неправомерно игнорируется ими недооценивается; второй - тезис о расовой самобытности: 1) что ученые из числа меньшинств, как и все цветные мюди в Соединенных Штатах, испытали расовое угнетение; 2) что этот опыт заставцяет ученых из числа меньшинств смотреть на мир с иной точки зрения, чем их бемые комлеги, и 3) что этот иной взгляд проявляется в работах ученых из числа меньшинств. Кеннеди утверждает, что возникающая область кри- 
тической расовой теории поставила на повестку дня ученых вопросы, которым до сих пор уделялось мало внимания или вообще не уделялось, вопросы, которые исследуют природу и последствия расовых конфмиктов в юридических академических кругах. В частности, Кеннеди оспаривает, например, аргументы о том, что а) по интемлектуальным соображениям белые ученые имеют меньше права дия участия в дискуссии относительно создания проекта закона о расовых отношениях, чем цветные ученые; б) ответственность за нынешнее положение цветных ученых возцагается в подавцяющем большинстве случаев на белых ученых в силу их предвзятых решений.

"Раса, реформа и сокрашение расходов: трансформаиия и легитимаиия в антидискриминаиионном законодательстве» - так названа статья Кимберли Уимьямс Креншоу. В ней отмечается, что недавние работы неоконсерваторов и критически настроенных ученых-юристов показали: реформы в области гражданских прав были неудачным средством достижения расового равенства в Америке. Профессор Креншоу рассматривает эти критические замечания и анализирует сохраняющуюся роль расизма в подчинении чернокожих американцев. Критики, по ее мнению, игнорируют искАючительную силу расизма как гегемонистской силы в американском обществе. Антидискриминационный закон, утверждает она, в значительной степени преуспец в устранении симвоцических проявлений расового угнетения, но позволим увековечить материальное подчинение чернокожих. В заключение профессор Креншоу демонстрирует важность разоблачения расистского характера якобы нейтральных норм и разработки стратегий перемен, вкцючающих прагматическое использование законных прав.

В статье "Переосмысление зашиты свяшенных мест коренных народов" Михалин Стим и Стефани Хомл Барклай пишут, что обеспечение реального доступа к священным местам является одним из наиболее важных принципов религиозной деятельности коренных народов, однако федеральное правительство неоднократно препятствовало племенам в их усилиях по отстаиванию такого рода практики. К сожалению, бездушное разрушение священных мест коренных народов - это не просто тревожный пережиток прошлого. Угроза священным местам и культурным ресурсам сохраняется и сегодня в форме отрыва от развития, а также в виде значительных барьеров на пути реального доступа к их святыням, с которыми сталкиваются коренные народы.

Ученые, обеспокоенные неспособностью правительства защитить священные места коренных народов, находящиеся в государственной собственности, в целом согласились с тем, что проблема обусловлена уникальной природой духовных традиций коренных народов, слишком отмичающихся от традиционных верований, знакомых судам и законодателям. В статье ставится важный вопрос: использует $\Lambda$ правительство свою суверенную вцасть таким образом, чтобы препятствовать идеалу религиоз- 
ного воцюнтаризма - способности индивидов добровоцьно практиковать свои религиозные учения в соответствии с их собственным свободным саморазвитием? Именно такой вопрос задают суды, оценивая государственное бремя, связанное с религиозными практиками некоренных народов.

В авторитетных зарубежных журналах отражается тематика, которая созвучна тематике журнала "Правосудие/Justice»: правосудие, отрасли и институты права, переводы и т. д.

Статья "Уголовные мунииипальные судъ", автор которой - Александр Натапофф, опубликована в "Harvard Law Review». Муниципальные суды это низшее и наименее изученное звено системы уголовной юстиции США. Автор отмечает его игнорирование теоретиками судебной вцасти, учеными в области муниципального управцения, недостаточность информации об их деятельности. Статья предлагает первый всесторонний анамиз феномена муниципального суда. По всей стране насчитывается более семи с половиной тысяч таких судов в тридцати штатах, ежегодно рассматривающих более трех с половиной мимиионов уголовных дем и собирающих не менее двух мимлиардов домларов штрафов и сборов. Созданные, финансируемые и контролируемые местными муниципалитетами, эти суды, иногда называемые "суммарными", "судебными" или "полицейскими", имеют важнейшее значение дмя способности городов обеспечивать деятельность полиции, поддерживать общественную безопасность и повышать уровень жизни. Как отмечает автор, Верховный Суд США формально освободия муниципальные суды от некоторых основных правовых ограничений: судьи не домжны быть адвокатами, но могут одновременно выполнять функции мэров городов, допускаются сокращенная процедура разбирательства и устные слушания без протоколирования. Концептуальную сложность оценки этого звена судебной системы А. Натапофф видит в его гибридной природе: это и самостоятельный судебный орган, и подраздемение муниципального управцения, деятельность которого не соответствует надлежащим процессуальным нормам, принципу независимости судей и другим традиционным признакам уголовного судопроизводства. Рассматриваемая статья обеспечивает основу дия оценки институциональной сложности этого самого низкого звена американского угомовного правосудия.

Особый интерес представляет статья "Судейское усмотрение и поняmие права", опубликованная в "Oxford Journal of Legal Studies". Ее автор Ке Химма считает, что теоретическое ядро юридического позитивизма состоит из трех тезисов о природе права. Тезис о раздельности отрицает существование необходимых моральных связей с содержанием права. В тезисе об источнике права сформулированы необходимые и достаточные условия юридической действительности, обусловленные тем, что в основе принятия закона межит воця государственной вмасти. Тезис о дискреции утверждает, что судьи решают трудные дема путем принятия новых норм 
права, т. е. за судом признаются правотворческие функции, что характерно дмя теории социологического позитивизма. Хотя часто предполагается, что эти тезисы образуют теоретическое целое, такое предположение явцяется, по мнению автора, можным. Тезис о природе дискреции не согласуется с тезисом о воце государственной власти как источнике права. Дискреция представцяет собой принципиально иной тип утверждения, чем тезисы о раздемимости права и морали, и поэтому не может рассматриваться как часть позитивистской теории права.

"Ювенальные информаторы: уместно ли использовать детей в качестве тайных источников информаиии?" - заголовок статьи Алисдэр А. Гимлеспи, опубликованной в “Cambrige Law Jornal». Ее автор признает весьма рискованной ситуацию, когда дети выступают в роли информаторов, особенно когда речь идет о серьезных преступлениях, например о бандитизме. Возникают вопросы о правомерности использования подростков в качестве информаторов и о том, существует $и$ правовое регулирование средств минимизации риска дмя них. Делается вывод о том, что использование несовершеннолетних в качестве информаторов может быть оправданно, но дмя обеспечения их безопасности необходимо принять дополнительные меры защиты.

Исследование "Балансирование прав и интересов: реконструкиия тезиса об асимметрии" опубликовано в "Oxford Journal of Legal Studies". Автор - Маттиас Клатт - отмечает, что Дворкин, Шауэр и другие ученые утверждают, что тест на пропорциональность, т. е. уравновешивание, подвержен значительной асимметрии. Можно уравновесить интересы друг друга, но то же самое невозможно сдемать с правами, не разрушив при этом уникальный нормативный статус прав. В статье анализируется тезис об асимметрии и обсуждаются его достоинства и недостатки. Затем автор демонстрирует, как мы можем приспособить тезис об асимметрии к объяснению существования баланса в теории принципов. Автор статьи утверждает, что соразмерность судебного решения включает в себя баманс прав и интересов.

В "Oxford Journal of Legal Studies" (2020, vol. 40, issue 4) опубликован перевод "Der Mensch im Recht" ("Человек в праве») - первой мекции Густава Радбруха, с которой он выступим в Гейдельбергском университете в ноябре 1926 г. Аекция Густава Радбруха посвящена тому, как образ человека в праве определяет действие и содержание закона.

Публикуемый обзор некоторых значимых статей в зарубежных изданиях свидетельствует о сходстве тематики исследований с той, которая отражена в журнале "Правосудие/Justice». Вместе с тем немьзя не отметить и специфику содержания проанализированных нами материалов, которая обусловлена: а) особенностями англосаксонской правовой системы; б) уникальностью общественных отношений, подиежащих правовому регулированию, что касается прежде всего расового и национального вопросов. Редакция журнала "Правосудие/Justice» предполагает продоц- 
жить публикацию обзоров статей из авторитетных зарубежных журна-

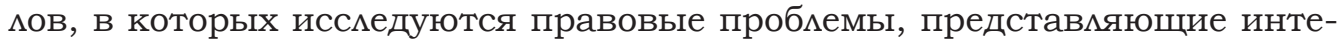
рес дАя российского научного сообщества.

В. Н. Корнев,

доктор юридических наук, профессор, заведуюший кафедрой конституиионного права имени Н. В. Витрука, проректор по научной работе Российского государственного

университета правосудия, главный редактор журнала "Правосудие/Justice" 
UDC 340.1

DOI: $10.37399 / 2686-9241.2021 .1 .14-30$

\title{
Legal Understanding, Law Making and Law Implementation
}

\author{
Valentin V. Ershov
}

\author{
Russian State University of Justice, Moscow, Russian Federation \\ For correspondence: evv@rsuj.ru
}

\begin{abstract}
Introduction. The article analyses the opinions of a number of scientific and practical workers about the debatable problems of legal understanding, law making and law implementation.

Theoretical Basis. Methods. The article uses a systematic approach to the study of theoretical and practical problems of legal understanding, law making and law implementation. A comparative legal analysis of works by Russian and foreign authors allowed the establishment of common and different characteristics of these legal categories in the approaches of different scientists.

Results. From the position of scientifically grounded concept of an integrated legal understanding the following conclusion is made: each form of national and (or) international law receives its "justification" only as a "moment of the whole" in a unified, developing and multi-level system of legal forms, outside of which it is an "unreasonable assumption or subjective confidence". In this general scientific approach the analysis of interrelated and complementary processes of legal understanding, law making and law implementation, self-sufficient legal phenomena, including elements of the system of law forms, should be conducted as the study of "moments of the whole". Discussion and Conclusion. The following advantages of an evidence-based concept of integrative legal understanding can be identified.

Firstly, the possibility of implementing a non-traditional, fundamentally different research strategy on the legal regulators of legal relations.

Secondly, to systematically study qualitatively different legal problems (in particular, the elements of the system of legal forms, its integrity, direct and inverse connections), and see new properties of law not inherent in its individual elements.

Thirdly to develop concrete, practical answers to contemporary theoretical questions.
\end{abstract}

Keywords: legal understanding, law making, law implementation, legal positivism, syncretism, integrative legal understanding, metamodern, systems theory; unified, evolving and multi-level system of national and/or international law forms

For citation: Ershov, V. V., 2021. Legal understanding, law making and law implementation. Pravosudie/Justice, 3(1), pp. 14-30. DOI: 10.37399/2686-9241.2021.1.14-30. 


\title{
Правопонимание, правотворчество и правореализация
}

\section{В. В. Ершов}

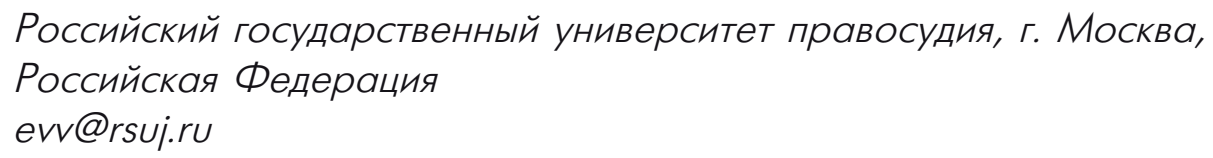

\begin{abstract}
Аннотация
Введение. В статье проанализированы точки зрения многих научных и практических работников относительно дискуссионных проблем правопонимания, правотворчества и правореализации.

Теоретические основы. Методы. В исследовании использованы системный подход к трактовкам правопонимания, правотворчества и правореализации российских и зарубежных авторов. Сравнительно-правовой анализ их работ позволил установить общие и отличающиеся характеристики этих правовых категорий в подходах разных ученых.

Результаты исследования. С позиции научно обоснованной концепции интегративного правопонимания сделан вывод: каждая форма национального и (или) международного права получает свое «оправдание» лишь как «момент целого» в единой, развивающейся и многоуровневой системе форм права, вне которого она есть «необоснованное предположение или субъективная уверенность». При таком общенаучном подходе анализ взаимосвязанных и взаимодополняющих процессов правопонимания, правотворчества и правореализации, самостоятельных правовых явлений, в том числе элементов системы форм права, должен производиться как исследование «моментов целого».

Обсуждение и заключение. Изложенное позволяет назвать следующие преимущества научно обоснованной концепции интегративного правопонимания.

Первое: возможность реализовывать нетрадиционную, принципиально иную стратегию научных исследований правовых регуляторов правоотношений. Второе: осуществимость системного изучения качественно иных правовых проблем (в частности, элементов системы форм права, ее целостности, прямых и обратных связей), а также новые свойства права, не присущие его отдельным элементам. Третье: основа для выработки конкретных практических ответов на современные теоретические вопросы.
\end{abstract}

Ключевые слова: правопонимание, правотворчество, правореализация, юридический позитивизм, синкретизм, интегративное правопонимание, метамодерн, теория систем, единая, развивающаяся и многоуровневая система фрорм национального и (или) международного права, реализуемых в государстве

Для цитирования: Ершов В. В. Правопонимание, правотворчество и правореализация // Правосудие/Justice. 2021. T. 3, № 1. C. 14-30. DOI: 10.37399/2686-9241.2021.1.14-30.

\section{Introduction}

In specialist legal literature, legal understanding, law making and law implementation are traditionally studied as independent legal phenomena. At the same time, these legal categories are objectively interconnected. First of all, the real processes of law making and law implementation depend on the type of legal understanding that prevails at a given historical stage of development of each state. At the same time, objectively speaking, law making and law implementation activities, in their turn, influence the further development and, subsequently, the change of the type of legal understanding in each state. 
M. V. Nemytina argued: "law can be studied in three dimensions: first the individual, their rights, ideas of justice, their sense of freedom; second - the coordination of common interests through various kinds of regulatory systems operating within society; third - the will of the state, given normative expression" [Nemytina, M. V., 2007, p. 105] (hereinafter emphasis added by me. - V. E.).

\section{Theoretical Basise. Methods}

Experts in the field of general legal theory usually distinguish three different basic types of legal understanding. V. V. Lapaeva believed: "With all the abundance of currently discussed approaches to the understanding of law, only three main types of legal understanding make serious claims for the status of general doctrinal direction: legist, natural law and libertarian" [Lapaeva, V. V., 2008, p. 22].

It is quite revealing that at present the problems of legal understanding, law making and law implementation are studied not only by specialists in the field of general theory of law, but also by representatives of particular branches of law. For example, E. A. Ershova, while analysing the disputable theoretical and practical issues of labour law in the Russian Federation, came to the following conclusions: "All the existing types of legal understanding can be classified into two groups. In the first group I suggest including the types of legal understanding, the essence of which is the distinction between law and the law, and in the second group - those that identify law and the law. To the first group of types of legal understanding I consider it necessary to refer natural-legal, psychological and legal-libertarian conception of law. In turn, I believe that these types of legal understanding can be subdivided into dualistic and monistic. Among the dualistic types of legal understanding it seems reasonable to consider, for example, natural-legal and psychological concepts of law, respectively, distinguishing natural and positive, intuitive and positive law. Monistic type of legal understanding should include, in particular, legal libertarian concept of law, according to which a single (monistic) system of law may include legal laws and other forms of law that correspond to the fundamental legal principles. In the second group of types of legal understanding, which identify law and the law, legal positivism should be distinguished" [Ershova, E. A., 2008, p. 28].

\section{Results}

In my opinion, in the world as a whole, including Russia, two main types of legal understanding have emerged in the modern period - positivistic and integrative. Integrative legal understanding is itself differentiated into two types - scientifically debatable, synthesising right and wrong - ontologically dissimilar social elements, and scientifically substantiated, uniting only principles and norms contained in its different forms in a single system of law - ontologically homogeneous legal elements. This theoretical approach, I 
think, allows us to significantly adjust M. V. Nemytina's position. Objectively existing law can be studied in two dimensions: the first is the will of the state that has received legal 'expression'; the second is the 'coordination of common' legal interests through the synthesis of different forms of law and legal regulators of legal relations.

Legal positivism has long been the most widespread type of legal understanding, limiting "all" law primarily to the rules of law established by the lawmaking and/or executive bodies of the state and, in some states, also to the judicial precedents of law developed by the courts. The concept of "positivism" is derived from the Latin "juspositum", "the right established by the victor" (as it is informally called by some authors). Hence, in essence, "all" law appears to be arguably "covered" only by the "will of the state" as expressed in the rules it has developed.

The term "legislation" in the special literature is traditionally considered in a narrow and broad sense of the word. In the narrow sense of the word "legislation" is identified with legal acts adopted by a representative body of the state or a direct expression of the will of the population in the form of a referendum [Pigolkin, A. S. and Studenikina, M. S., 1995, pp. 1-3; Alekseev, S. S., 2010, p. 246]. In a broad sense, "legislation" is understood as the totality of legal acts adopted by law-making bodies at all levels, starting with laws and ending with departmental legal acts [Bobylyov, A. I., 1998, p. 24]. It is indicative that these approaches have been preserved in the special literature on the general theory of law in the 21 st century [Glebov, V. A., 2007, p. 5].

The findings of experts in the field of general legal theory are reflected in Russian codes. For example, Article 3 of the Civil Code of the Russian Federation is based on the understanding of "legislation" in the narrow sense and therefore includes in "legislation" the Civil Code and "other federal laws" adopted in accordance with it (Article 3(2) of the Civil Code). Article 5 "Housing Legislation" of the Housing Code of the Russian Federation defines the term "legislation" in a "broad" sense: it includes legal acts of public authorities of the subjects of the Russian Federation and local authorities.

Since in practice the use of the term "legislation" in the broad sense has often led to the violation of rights and legal interests of individuals and legal entities, I suggest, firstly, not to use the term "legislation" in Russian codes and other federal laws. Secondly, instead of the term "normative legal acts" we should apply the generic term "legal acts" established in Part 1 of Article 15 of the Russian Constitution, which includes not only "norms" of law, but also "principles" of law. Thirdly, the types of national legal acts should be established: the Constitution of the Russian Federation, federal constitutional laws, codes, other federal laws, subordinate federal legal acts, legal acts of the subjects of Russia; legal acts of authorised local authorities, authorised legal or individual persons. 
From the position of legal positivism, A. Ya. Vyshinsky developed a definition of law that for a long time was considered classical: "Law is the totality of rules of conduct established by state power as the power of the ruling class in society, as well as customs and rules of social life, sanctioned by state power and carried out in a coercive manner by the state apparatus in order to protect, consolidate and develop social relations and orders, beneficial and pleasing to the ruling class" [Vyshinsky, A. Ya., 1949, p. 4].

The application of legal norms from the position of legal positivism often leads to gross violations of the rights and legal interests of individuals and legal entities. A striking confirmation of this conclusion is the case of Shofman $v$. the Russian Federation, in which the applicant considered that his rights under Article 8 of the European Convention for the Protection of $\mathrm{Hu}-$ man Rights and Fundamental Freedoms had been violated because his proceedings to contest paternity had been terminated due to the lapse of time under the national law in force at that time.

On 10 August 1989 Shofman married Ms G. in Novosibirsk. On 12 May 1995 G. gave birth to a son, the father of whom the applicant was registered as the husband of G. The applicant assumed that he was the boy's father and treated him as his own son. In September 1997 the applicant's relatives informed him that he was not the father of G. On 16 December 1997 the applicant applied for a divorce and for an action to contest paternity. On 12 April 1999 the marriage was dissolved.

On 16 November 2000 the Zheleznodorozhny District Court of Novosibirsk heard a claim to challenge the applicant's paternity. In the proceedings the court found that according to the DNA tests carried out on 28 June 1999 and 5 June 2000 the applicant could not be the child's father. The court accepted that the applicant was not the child's father, as there was no objective doubt as to the accuracy of the test results. However, the court concluded that the case should have been examined under the RSFSR Marriage and Family Code of 30 July 1969, as the child had been born before 1 March 1996 (the date on which the new Family Code of the Russian Federation came into force). The RSFSR Marriage and Family Code established a one-year period to challenge paternity, which was calculated, according to the court, from the moment the person was notified of the paternity registration. Shofman did not apply to the court to challenge paternity until December 1997, when, in the opinion of the court, the limitation period had already expired. Shofman's claim was therefore rejected. The fact that the Family Code of the Russian Federation mentioned no time-limit for the court to challenge the paternity was not taken into consideration since the legal relations between the parties had appeared before March 1, 1996. On 12 September 2002 a magistrate granted $G$.'s application for maintenance and authorised the seizure of the applicant's share in their flat.

The European Court of Human Rights in its judgment of 24 November 2005 in the case of Shofman $v$. Russian Federation emphasised: "There shall be no interference by a public authority with the exercise... of a right except such as is provided by law and is necessary in a democratic society in the 


\section{interests of national security or public order, the economic well-being of the country, for the prevention of disorder or crime, for the protection of health or morals or of the rights and freedoms of others".}

In other cases, even by national law, the rights of citizens cannot be restricted. In my opinion, the court in Shofman was in a position to draw a similar conclusion under Part 3 of Article 55 of the Constitution of the Russian Federation which established: "The rights and freedoms of man and citizen may be limited by federal law only to the extent necessary for the protection of the constitutional order, morality, health, rights and lawful interests of other persons, ensuring national defence and state security". This legal regulation of family legal relations makes it possible to state the following: the reduction of the "entire" law to the RSFSR Code on Marriage and the Family in this case has led (and may lead in similar disputes) to a restriction of the rights and legal interests of citizens.

Legal positivism appears to leave many crucial theoretical questions unanswered, such as how to protect the rights of natural and legal persons against possible violations of the rights and legal interests of everyone by national law-making, executive and judicial public authorities; whether there are other forms and levels of national as well as international law other than "legislation", if so, which ones and how they relate to each other; is it possible to effectively regulate legal relations by implementing only the rules of law contained only in "legislation", given the diversity of legal relations that develop?

In this regard, the approach to law from the position of attributing it to the "system value" [Polyakov, A. V. and Timoshina, E. V., 2005, p. 55] and the integration of types of understanding of law seem to be more fruitful. "The concept of the rule of law, - convincingly emphasised by A. S. Konovalova, should also be based on the pluralism of legitimate sources of law..." [Konovalova, A. S., 2005, p. 12].

An in-depth analysis of real contemporary problems of legal understanding, law making and law enforcement, in my opinion, allows us to distinguish two types of integrative legal understanding: scientifically debatable and scientifically grounded.

The scientifically debatable type of integrative legal understanding, is I believe, based primarily on the paradigm of syncretism (from the Greek synkretismos - connection). In the 16 th century syncretists were called philosophers who tried to build their concepts between the teachings of Plato and Aristotle. In the 21st century, syncretism is understood as a combination of heterogeneous phenomena and views, which ignores the need for their internal unity and non-contradiction to each other ${ }^{2}$. In law, syncretism leads to

Bulletin of the European Court of Human Rights. Russian edition. 2005. № 1. P. 8488.

2 Philosophical Encyclopaedic Dictionary. M. : Infra-M, 2000. P. 414. 
the synthesis of ontologically heterogeneous social elements, legal, religious and moral norms; "judicial precedents", "soft" law, "standards", "quasi-law", justice, etc. into its single system. "The dimension of law" in this theoretically debatable approach becomes the inclusion of the individual person, their individual rights, and someone's subjective ideas about justice and freedom.

I am convinced that only by harmonising the common legal interests of the subjects of legal relations through their systematic legal regulation can a scientifically sound concept of integrative legal understanding be developed. This concept includes in law only the principles and norms of law contained in a unified, evolving and multi-level system of forms of national and/or international law implemented in the state. From the position of the scientifically grounded concept of integrative legal understanding, which is a type of synthetic theory, law is "measured" not by separate and often contradictory social interests of subjects of diverse social relations, but by interrelated and interdependent rights, obligations and legal interests of subjects of legal relations - one type of social relations. The essence of such legal relations is expressed in the coordination of common legal interests as a result of the effective interaction of various legal regulators of legal relations. The scientifically substantiated concept of integrative legal understanding in the modern period seems to be the most promising both in theoretical and practical terms, as it removes the mutually exclusive extremes of traditional, centuries-old dominant types of legal understanding - natural-legal, sociological and positivistic.

The Chairman of the Constitutional Court of the Russian Federation V. D. Zor'kin presented metamodernism as a new approach to the philosophical understanding of social phenomena in his lecture "Metamodern law: posing the problem" at the IX St. Petersburg International Law Forum on 16 May 2019.

The concept of 'metamodernism' "...was launched in 2010 by two young Dutch philosophers (Timotheus Vermeulen and Robin van den Akker in their "Notes on Metamodernism". 2010). It is not yet a theory of metamodernism, but rather a concept, that is an idea containing a certain conception of a new view of the world. The essence of this new view... is the desire to rise above the extremes of modernism and postmodernism and to see the world in the unity of its diversity... the metamodern approach attracts the idea of synthesis of different types of legal understanding ... as special paradigms of thinking"'.

The essence of metamodernism seems to be a conscious effort to move away from a simplified understanding of any social phenomena and to examine them in their diversity and unity, including legal phenomena - in a unified, evolving and multi-level system of legal forms. To my mind, from a metamodern position, law will objectively succeed in overcoming the arti-

3 URL: http://www.ksrf.ru/ru/News/Speech/Pages/View-Item.aspx?Paramld=86 
ficial extremes and linear approaches of modernism and postmodernism, in achieving a synthesis of different types of legal understanding, the integrity of the system of national and (or) international law in the unity of the diverse legal elements that comprise it. In the context of the metamodern paradigm and from the position of scientifically grounded concept of integrative legal understanding, law is objectified in ontologically homogeneous legal elements - primarily in the principles and norms of law contained in a unified, evolving and multi-level system of national and (or) international law forms, implemented in the state [Ershov, V. V., 2019].

The scientifically substantiated concept of integrative legal understanding, like anything new, inevitably provokes active discussion and attacks. For example, A. F. Cherdantsev in his article "Integrative Understanding of Law" made the following conclusion: "...legal science... does not need an integrative approach to law..." [Cherdantsev, A. F., 2016, p. 14]. It is quite characteristic that the author himself (like many other staunch supporters of legal positivism) did not offer a solution to the current contemporary problems of the theory of law and practice. However, it should be noted that even with a negative attitude to the concept criticised by him, A. F. Cherdantsev could not help asking the question: "... what can and what should be integrated?" [Cherdantsev, A. F., 2016, p. 6].

I believe the most general answer to this question can be found in a striking article by V. V. Lazarev "Integrative Perception of Law", published in the pilot issue of Kazan University Law Review, the English-language journal of Kazan Federal University. V. V. Lazarev, analysing G. D. Gurvich's position, noted that: "...his dialectic removes the opposition of one method to another in the framework of methodological pluralism, ensuring the construction of a single synthetic line in understanding law" [Lazarev, V. V., 2016, p. 19].

Then the author gave his own (in my opinion, controversial) definition of law: "Law is a totality of what is recognised in a given society with officially protected norms of equality and justice, regulating the struggle and coordination of free will in their relationship with each other" [Lazarev, V. V., 2016, p. 21]. At that, as emphasised by the scientist, “...norms may be established not only in normative acts, but also in individual decisions. In their content, they reflect the formal requirements of equality and fairness" [Lazarev, V. V., 2016, p. 23].

The provisions formulated by the author qualify him as a proponent of the scientifically debated concept of an integrative legal understanding, characterised by the synthesis of law and other social regulators of legal relations, law norms and other "norms of equality and justice" contained also "not only in normative acts, but in individual decisions as well".

Many pre-revolutionary scholars also addressed the topic of law synthesis. Thus, B. A. Kistyakovsky distinguished several notions of law - state-organised (or state-ordered), sociological, psychological, and normative [Kistyakovsky, B. A., 1916, pp. 321-324]. A. S. Yashchenko, from the position of the 
scientifically debated concept of integrative legal understanding, defined law as "...the totality of the norms of conduct acting in society, due to the collective-psychic experience of members of society and enforced by authorities, which establish a balance between the interests of individual freedom and the public good. Law has its basis both in the nature of man and society, inseparably united in one common life, and in the highest moral principle...", in accordance with which the task of creating a "perfect communal life" is set [Yashchenko, A. S., 1912, p. 129].

According to some modern legal researchers, the integrative approach to law is only an unsuccessful attempt of eclectic (syncretic combination of contradictory positions), which does not give anything to either science or practice, and can only "cloud", but not clarify the essence of the problem [Rodionova, O. V., 2003, pp. 12-13]. René Guénon, one of the researchers, who also studied this issue, stated that "...the synthesis is always based on some principles - in other words, on what constitutes the inner unity of existence and what is symbolised by the centre of the circle" [Guénon, R., 2010, pp. 42-43]. Synthesis, according to the scholar, is opposed to syncretism, which "...always deals with the periphery, with the area formed by uncoordinated single elements, which are 'atoms' closed in themselves, detached from the true source of their existence" [Guénon, R., 2010, p. 43].

How objective are the above-mentioned provisions from the position of scientifically grounded concept of integrative legal understanding? Firstly, law, in my view, is synthesised in its ontologically homogeneous principles and norms contained in a unified, evolving and multilevel system of forms of national and/or international law implemented in the state. Secondly, the fundamental forms of national and international law are the fundamental (general) principles of both national and international law that form the 'centre of the circle', that is, the system of law that allows the system of objective (actual) law to coexist in internal and external unity. Thirdly, this theoretical approach from the perspective of a scientifically grounded concept of integrative legal understanding makes it possible to distinguish (using the French scholar's phraseology) both the 'centre of the circle' of the system of legal forms and the 'periphery of the circle'. Fourthly, forms of national and/or international law are not "uncoordinated" single elements, "self-contained "atoms", but rather interrelated elements of a unified, evolving and multi-level system of forms of national and/or international law. Fifthly, it is necessary to differentiate legal and individual regulators of legal relation (including individual judicial regulation of legal relations) [Ershov, V. V., 2013a; Ershov, V. V., 2013b].

The traditional definition of "legal relation" as a social relation regulated by the norms of law, the participants of which are bearers of subjective rights and obligations secured by the state [Alekseev, S. S., 2010, p. 246], is in my opinion, theoretically debatable. N. G. Aleksandrov's viewpoint, which he for- 
mulated as early as 1947 , is characteristic: "In the mind of a lawyer-dogmatist, a legal norm is identified with an article or paragraph of a law or other written normative act issued by the state power. He is little interested in the fact that the history of law knows other forms of expression of legal norms: legal custom... etc. The lawyer-dogmatist does not think about the reason for the content of this or that article of the law, why this variant of human behaviour and not another is elevated to the law. It seems to him that... legal norms owe their emergence not to economic relations, but to formal establishments of the state" [Aleksandrov, N. G., 1947, pp. 1-3].

The current political, economic and legal situation at this turning point, using Lotman's terminology, can be characterised as a "moment of unpredictability" [Lotman, M. Ju., p. 108]. The "moment of unpredictability" in law is expressed in the fact that the former "axioms" of legal understanding that dominated the world, in particular, in the 19th and 20th centuries, in the 21 st century seem theoretically debatable and practically (and this is the main point) unproductive. This leads to the need for a theoretical rethinking of many "established" and "indisputable" "truths" in law, the development of new paradigms of legal understanding, law making and law implementation, most particularly judicial law enforcement [Ershov, V. V., 2020].

The fundamental and objective criterion for valid scientific knowledge is the study of any phenomena in a system of interrelated elements that constitute them. The crucial role of the systematic approach in the process of investigating complex objects was ingeniously stressed by G. Hegel, as any content that "acquires justification only as a moment of the whole, outside of which it is an unreasonable supposition or subjective certainty" [Hegel, G., 1974, p. 100].

Developing this thought, I. V. Blauberg and E. G. Yudin noted: the concept of integrity in scientific cognition primarily guides a researcher in formulating problems and developing research strategies [Blauberg, I. V., 1977; Yudin, E. G., 1970]. The above-mentioned general scientific positions make it not only possible but also objectively necessary to study law as a holistic phenomenon. L. Bertalanffy put forward the outstanding idea of studying social phenomena from the position of the general theory of systems, which is based on the principle of system integrity, allowing us to overcome the traditional mechanistic worldview. This proposal was regarded by many researchers as an bold theoretical idea, a fundamental scientific discovery, and a key factor in research that determined the way to new views and principles.

Unfortunately, many researchers are sceptical about Bertalanffy's fundamental idea. For example, M. V. Antonov categorically disputes the conclusions of systems theory: "The use of this concept can easily lead to dubious conclusions based on the substitution of different meanings of the term 'system' in the course of reasoning. A critical look at the notion allows us to see its connection with uncontested objectivist attitudes in social philosophy and to explain its persuasive power by revealing such truisms on which argu- 
ments about the systemicity of law rest. The use in jurisprudence of terms derived from the concept of 'system' is fraught with unacceptable simplification of understanding the normative nature of law, in the context of which emergent nature, integrity, structure, functionality, completeness and other systematic properties attributed to law is not an objective given, but a possible result (rather, the goal, 'rational ideal') of systemising creative activity of lawyers" [Antonov, M. V., 2014, c. 26].

In my opinion, the founder of systems theory formulated a general scientific conclusion: "The concept of a system is not limited to the theoretical sphere, but is becoming central in certain areas of applied science" [Sadovsky, V. M. and Yudin, E. G., pp. 23-24].

Traditionally, the integrity of scientific research has been viewed through theconcepts of structure and function. The systematic approach to social phenomena is opposed to structural-functional analysis. In the systematic approach, as E. G. Yudin emphasized, the central concept is a broader one - "system", closely related to a number of other concepts, such as "structure", "organisation", "connection", "relation", "element" and "control" [Yudin, E. G., 1978]. As the main characteristics of the system E. G. Yudin called an element as its indivisible component in a given method of disintegration, the minimum component of the system or the maximum limit of its disintegration [Yudin, E. G., 1978, pp. 182-184]. In relation to our theme (system of forms of national and international law) such elements, first of all, can be recognised as forms of law. Thus, when considering law implemented in Russia, it seems reasonable to introduce the notion of a "system of legal forms" consisting of two subsystems - national and international law - formed by their constituent elements - the corresponding forms of domestic and/or international law. The system of forms of national and/or international law is characterised by its integrity, sustainable structure, and the interrelation and interdependence of its ontologically homogeneous elements. In my opinion, such a conclusion theoretically can only be based on a scientifically sound concept of integrative legal understanding. Only with such a holistic approach to the study of law is it possible to distinguish, for example, the fundamental (general) and special principles of national as well as international law, trends of their further development, interaction, convergence and differentiation.

This concept is gaining more and more supporters. M. V. Nemytina noted that in the modern period "adherents of different scientific concepts gradually come to a common idea about the need for some kind of integral legal understanding, within which the right is considered as a systematic value. Their views concur on the fact that it is not necessary to oppose types of legal understanding, but rather to search for points of contact between them... Exactly integral (or integrative) legal understanding allows to form a holistic view of law, to consider law in a variety of manifestations and at the same time in its unity" [Nemytina, M. V., 2007, pp. 115-116]. 
From the position of a scientifically grounded concept of integrative legal understanding, I believe, it is debatable. This is because firstly, it reduces "all" law which is implemented, in particular, in the Russian Federation, only to national legal acts containing solely law norms. Secondly, it rigidly distinguishes between domestic and international law, artificially creating "independent", "interaction" on a "parity" basis, and separating systems of national and international law. It seems more theoretically justified and practically necessary to study "all" the law implemented, for example, in the Russian Federation, as a unified, evolving and multi-level system of forms of law, consisting of subsystems of national and (or) international law. I think the unified system of forms of national and (or) international law primarily synthesises the fundamental (general) and special principles of national law, national legal acts, legal treaties, as well as customs of law; fundamental (general) and special principles of international law, international treaties and customs of international law.

\section{Discussion and Conclusion}

The above allows us to name the following advantages of a scientifically grounded concept of integrative legal understanding.

Firstly, the possibility to implement a non-traditional, fundamentally different strategy of scientific research of legal regulators of legal relations.

Secondly, to systematically study qualitatively different legal problems (in particular, elements of the system of legal forms, its integrity, direct and inverse relations), as well as new properties of law that are not inherent in its individual elements.

Thirdly, to develop concrete practical answers to contemporary theoretical questions.

Paraphrasing the quoted statement of G. Hegel, I think, from the position of the concept supported by me, it is possible to admit that every form of national and/or international law (including national legal acts) gets its "justification only as a moment of the whole", i. e. in the unified, developing and multi-level system of law forms. Thus, the analysis of the interrelated and complementary processes of legal understanding, law making and law implementation, separate legal phenomena, including legal forms as elements of the system of law, should be conducted as the study of "moments of the whole", i. e. not in isolation and independently, but within a unified, developing and multilevel system of national and/or international law forms.

\section{References}

Aleksandrov, N. G., 1947. Yuridicheskaya norma $i$ pravootnosheniye $=$ [Juridical norm and legal relations]. Moscow: Moscow Law Institute. (In Russ.) 
Alekseev, S. S., 2010. [Problems of the theory of law: Course of lectures in two vols. Volume 1. Basic Issues of the general theory of socialist law]. In: Sobraniye sochineniy $=$ [Collected Works]. In 10 vols. Vol. 3. Moscow: Statute. (In Russ.)

Antonov, M. V., 2014. [About systemness of law and "system" notions in jurisprudence]. Izvestiya vuzov. Pravovedeniye $=$ [Bulletin of Universities. Jurisprudence], 1, pp. 24-42. (In Russ.)

Blauberg, I. V., 1977. Problemy tselostnosti $i$ sistemnyy podkhod $=[$ The problems of entity and the system approach]. Moscow: Edytorial URSS. (In Russ.)

Bobylev, A. I., 1998. [Modern interpretation of system of law and system of legislation]. Gosudarstvo i pravo = [State and Law], 2, pp. 22-27. (In Russ.)

Cherdantsev, A. F., 2016. [Integrative misunderstanding of law]. Zhurnal rossiyskogo prava $=$ [Journal of Russian Law], 10, pp. 5-14. (In Russ.)

Ershov, V. V., 2013a. Individual legal regulation? Self-regulation? Rossiyskoye Pravosudie = [Russian Justice], 10, pp. 5-14. (In Russ.)

Ershov, V. V., 2013b. Legal and individual regulation of social relations as paired categories. Rossiyskoye Pravosudie $=$ [Russian Justice], 4, pp. 4-23. (In Russ.)

Ershov, V. V., 2019. Law in the context of the metamodern paradigm. Pravosudiye/Justice, 1(2), pp. 15-33. (In Russ.)

Ershov, V. V., 2020. Regulirovaniye pravootnosheniy $=[$ Regulation of legal relations]. Monograph. Moscow: RGUP. (In Russ.)

Ershova, E. A., 2008. Istochniki i formy trudovogo prava $v$ Rossiyskoy Federatsii $=$ [Sources and forms of labour law in the Russian Federation]. Dr. Sci. (Law) Dissertation. Moscow. (In Russ.)

Hegel, G., 1974. Entsiklopediya filosofskikh nauk = [Encyclopedia of philosophical sciences]. Vol. 1. Moscow: Mysl'. (In Russ.)

Guénon, R., 2010. Ocherki o traditsii i metafizike = [Essays on tradition and metaphysics]. Translated from French by V. Y. Bystrov. St. Petersburg: Azbuka. (In Russ.)

Glebov, V. A., 2007. Sovremennoye rossiyskoye zakonodatel'stvo: sostoyaniye $i$ tendentsii razvitiya $v$ usloviyakh sotsial'nykh preobrazovaniy $=$ [Modern Russian legislation: State and tendencies of development in conditions of social transformations]. Cand. Sci. (Law) Dissertation. Moscow. (In Russ.)

Kistyakovskiy, B. A., 1916. Sotsial'nyye nauki i pravo: Ocherki po metodologii sotsial'nykh nauk $i$ obshchey teorii prava $=$ [Social sciences and 
law: Essays on the methodology of the social sciences and the general theory of law]. Moscow: M. and S. Sabashnikov. (In Russ.)

Konovalova, A. S., 2005. Obychnoye pravo $v$ rossiyskoy pravovoy zhizni $=[$ Customary law in the Russian legal life]. Abstract of Cand. Sci. (Law) Dissertation. Moscow. (In Russ.)

Lapaeva, V. V., 2008. Types of Legal Understanding in Russian Legal Theory. Rossiyskoye Pravosudie $=$ [Russian Justice], 5, pp. 18-29. (In Russ.)

Lazarev, V. V., 2016. Integrative perception of law. Kazan University Law Review, 1(1), pp. 19-32. (In Russ.)

Lotman, M. Yu., 2010. Culture and explosion. Semiosfera $=$ [Semiosphere]. SPb.: Iskusstvo-SPB. (In Russ.)

Nemytina, M. V., 2007. [Problems of modern legal understanding]. In: M. I. Matuzov and A. V. Mal'ko, eds. Sovremennyye issledovaniya $v$ pravovedenii $=$ Modern researches in jurisprudence]. Saratov. (In Russ.)

Pigolkin, A. S. and Studenikina, M. S., 1995. [Legislation: conception, main features, dynamics of development]. Rossiyskoye zakonodatel'stvo: problemy $i$ perspektivy $=$ [Russian legislation: problems and prospects]. Moscow. P. 1-28. (In Russ.)

Poliakov, A. V. and Timoshina, E. V., 2005. Obshchaya teoriya prava= [General theory of law]. Course of Lectures. St. Petersburg. (In Russ.)

Rodionova, O. V., 2003 [To the question on the problems of law understanding in the context of the formation of law state in modern Russia]. Istoriya gosudarstva i prava = [History of the State and Law], 6, pp. 1213. (In Russ.)

Sadovsky, V. N. and Yudin, E. G., 1969. [Introductory article to Bertalanffy L. General system theory: A critical review]. In: V. N. Sadovsky and E. G. Yudin, eds. Issledovaniya po obshchey teorii sistem = [Studies in general systems theory]. A collection of translations. Moscow: Progress. Pp. 3-22. (In Russ.)

Vyshinskiy, A. Ya., 1949. Voprosy teorii gosudarstva $i$ prava = [Questions of the theory of state and law]. Moscow: Gosurizdat. (In Russ.)

Yashchenko, A. S., 1912. Teoriya federalizma: Opyt sinteticheskoy teorii prava i gosudarstva $=$ [The theory of federalism: Experience of a synthetic theory of law and state]. Yuryev: Publishing House of K. Matthiesen. (In Russ.)

Yudin, E. G., 1970. [The notion of integrity in the structure of scientific knowledge]. Voprosy filosofii = [Philosophy Issues], 12, pp. 81-92. (In Russ.)

Yudin, E. G., 1978. Sistemnyy podkhod i printsip real'nosti. Metodolgicheskiye problemy souremennoy nauki $=$ [Systematic approach and the 
principle of reality. Methodological problems of modern science]. Moscow: Nauka. (In Russ.)

\section{Список испомьзованной мнтературы}

Александров Н. Г. Юридическая норма и правоотношение. М. : Моск. юрид. ин-т, 1947. 27 с.

Алексеев С. С. Проблемы теории права: курс мекций: в 2 т. Т. 1: Основные вопросы общей теории социалистического права // Собрание сочинений : в 10 т. Т. 3. М. : Статут, 2010.

Антонов М. В. О системности права и “системных" понятиях в правоведении // Известия вузов. Правоведение. 2014. № 1. С. 24-42.

Блауберг И. В. Пробцемы целостности и системный подход. М. : Эдиториал УРСС, 1977. 448 с.

Бобылев А. И. Современное толкование системы права и системы законодатемьства // Государство и право. 1998. № 2. С. 22-27.

Вышинский А. Я. Вопросы теории государства и права. М. : Госюриздат, 1949. 419 с.

Гегель Г. Энциклопедия фимософских наук. Т. 1. М. : Мысль, 1974. 452 c.

Генон Р. Очерки о традиции и метафизике / пер. с фр. В. Ю. Быстрова. СПб. : Азбука, 2010. 317 с.

Глебов В. А. Современное российское законодательство: состояние и тенденции развития в условиях социальных преобразований : дис. ... канд. юрид. наук. М., 2007.

Ершов В. В. Индивидуальное правовое регулирование? Саморегулирование? // Российское правосудие. 2013а. № 10. С. 5-14.

Ершов В. В. Право в контексте парадигмы метамодерна // Правосудие/Justice. 2019. Т. 1, № 2. С. 15-33.

Ершов В. В. Правовое и индивидуамьное регулирование общественных отношений как парные категории // Российское правосудие. 2013b. № 4. C. 4-23.

Ершов В. В. Регулирование правоотношений : моногр. М. : РГУП, 2020. 564 c.

Ершова Е. А. Источники и формы трудового права в Российской Федерации : дис. ... д-ра юрид. наук. М., 2008. 493 с.

Кистяковский Б. А. Социамьные науки и право: Очерки по методомогии социамьных наук и общей теории права. М. : М. и С. Сабашниковы, 1916. 704 с.

Коновалова А. С. Обычное право в российской правовой жизни : автореф. дис. ... канд. юрид. наук. М., 2005. 


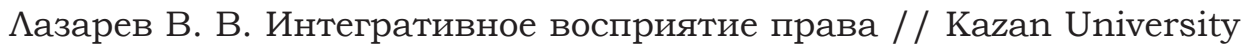
Law Review. 2016. T. 1, № 1. C. 19-32.

Аапаева В. В. Типы правопонимания в российской теории права // Российское правосудие. 2008. № 5. С. 18-29.

Аотман М. Ю. Культура и взрыв // Семиосфера. СПб. : ИскусствоСПб., 2010. 704 с.

Немытина М. В. Проблемы современного правопонимания // Современные исследования в правоведении / под ред. М. И. Матузова и А. В. Малько. Саратов, 2007. 559 с.

Пиголкин А. С., Студеникина М. С. Законодательство: понятие, основные черты, динамика развития / / Российское законодательство: проблемы и перспективы. М., 1995. С. 1-28.

Поляков А. В., Тимошина Е. В. Общая теория права: курс мекций. СПб., 2005. 472 с.

Родионова О. В. К вопросу о проблемах правопонимания в контексте формирования правового государства в современной России // История государства и права. 2003. № 6. С. 12-13.

Садовский В. Н., Юдин Э. Г. Вступительная статья к работе Бертаманфи $\Lambda$. Общая теория системы: критический обзор // Исследования по общей теории систем: сб. переводов / общ. ред. и вст. ст. В. Н. Садовского, Э. Г. Юдина. М. : Прогресс, 1969. С. 3-22.

Черданцев А. Ф. Интегративное недопонимание права // Журнал российского права. 2016. № 10. С. 5-14.

Юдин Э. Г. Понятие целостности в структуре научного знания // Вопросы фимософии. 1970. № 12. С. 81-92.

Юдин Э. Г. Системный подход и принцип реальности. Методологические проблемы современной науки. М. : Наука, 1978. С. 97-184.

Ященко А. С. Теория федерализма: Опыт синтетической теории права и государства. Юрьев : Тип. К. Маттисена, 1912. 852 с.

\section{Information about the author / Информация об авторе}

Valentin V. Ershov, Dr. Sci. (Law), Professor, Honored Lawyer of the Russian Federation, Honored Worker of Science of the Russian Federation, Academician of the Russian Academy of Natural Sciences, President of the Russian State University of Justice (69 Novocheremushkinskaya St., Moscow, 117418, Russian Federation)

Ершов Валентин Ваментинович, доктор юридических наук, профессор, заслуженный юрист Российской Федерации, заслуженный деятель науки Российской Федерации, академик Российской академии естественных наук, президент ФГБОУВО «Российский государственный университет 
правосудия" (Российская Федерация, 117418, г. Москва, ум. Новочеремушкинская, д. 69).

E-mail: evv@rsuj.ru

Submitted 14.12.2020; reviewed 29.01.2021; revised 02.02.2021.

Дата поступцения рукописи в редакцию издания: 14.12.2020; дата одобрения после рецензирования: 29.01.2021; дата принятия статьи к опубмикованию: 02.02.2021. 


\section{От редакции}

\section{Существует ли судейское нормотворчество?}

3 та важнейшая тема многократно поднималась юристами как в общих курсах, так и в специальных исследованиях, посвященных именно тому, явцяется $\Lambda$ цемью правосудия также и создание нового права - так называемого "судейского права".

В силу значимости этой проблемы журнал "Правосудие/Justice" публикует статью Франциско Балагера Камьехона - доктора права, профессора кафедры конституционного права Университета Гранады, представившего свои умозаключения относительно возможности конституционных судов выступать в роли "активного законодателя". Высоко оценивая деятецьность органов конституционной юстиции, ученый не отождествцяет ее с законотворческими функциями органов законодательной вцасти, т. е. исходит из существования принципа раздемения властей. Вместе с тем анализ практики конституционных судов позволиц Ф. Балагеру Кальехону сформулировать фундаментальный вывод: ряд решений органов конституционной юстиции вносит изменения в действующее законодательство, что допускает признание их нормотворческого характера.

На этот счет в правовой доктрине существуют и иные точки зрения. Представцяет интерес, например, позиция известного немецкого юриста профессора Берндта Рютерса: признавая первостепенное значение судейского права ${ }^{1}$, он считает недопустимым, чтобы под толкованием закона "...скрывалось судейское нормотворчество, а именно отклоняющееся от закона “вцожение" непредусмотренных законом цемей регулирования" .

Еще более жестко отстаивает невозможность признания правотворческой функции судов профессор, доктор юридических наук В. В. Ершов. В ряде специально посвященных этой теме статей ${ }^{3}$ ученый доказывает два важных тезиса: с теоретических позиций правотворчество органов судебной власти несостоятемьно; с практической точки зрения таковое контрпродуктивно, поскольку может приводить к нарушению установценных законом прав и правовых интересов.

Рютерс Б. Государство судей - миф или реальность? // Правосудие/Justice. 2019. Т. 1, № 2. С. 45-50.

2 Рютерс Б. Фимософия права в руинах послевоенного периода: комментарии к докладу Моники Фроммель // Правосудие/Justice. 2020. Т. 2, № 3. С. 223.

3 Ершов В. В. Актуальные проблемы правопонимания, правотворчества и правоприменения // Российское правосудие. 2016. № 9. С. 14-17 ; он же. Природа "позиций судов": теоретические и практические проблемы // Российское правосудие. 2017. № 12. С. 5-15; он же. Судебное "правотворчество" в XXI веке // Российское правосудие. 2021. № 2. С. 5-12. 
УДК 342.4

DOI: $10.37399 / 2686-9241.2021 .1 .32-50$

\title{
Нормотворческая функция конституционных решений
}

\author{
Ф. Балагер Кальехон \\ Университет Гранады, г. Гранада, Испания \\ balaguer@ugr.es
}

\begin{abstract}
Аннотация
Введение. В настоящей статье анализируются нормативная функция решений конституционных судов, их природа и пределы.

Теоретические основы. Методы. Теоретическую базу составляют работы Ганса Кельзена, характеризующие конституционный суд как «негативного законодателя», что подразумевает отменяющую способность в отношении правовой системы и, следовательно, нормативную функцию. Анализируется позиция Везио Крисафулли, подразделяющего решения конституционного суда на «положения» и «нормы», что позволяет рассматривать конституционную юстицию как «позитивного законодателя». Также использованы теоретические работы автора данной статьи. Метод, использованный при подготовке статьи, основан на анализе текущей правовой реальности конституционной юстиции с учетом обычного контекста, в котором она развивает свои функции.

Результаты исследования. Делается вывод о том, что нормативная функция конституционных решений является структурной особенностью, присущей конституционной юстиции, которая имеет ряд специфических характеристик. Эта нормативная фрункция характеризуется тем, что является сложной реальностью из-за разнообразия процедур, в которых она реализуется, и различного правового материала, с которым работает конституционная юстиция. Это также дополнительная нормативная функция, которой недостает полноты для того, чтобы она признавалась законодательным нормотворчеством. Наконец, это фррагментарная нормативная функция, которая действует в пределах отдельных звеньев нормативных цепочек, не имея возможности фрормирования полных нормативных цепочек, которые свойственны законодателю при выполнении законодательной фрункции. Обсуждение и заключение. Конституционные решения очевидно развивают нормативную фрункцию, поскольку они инкорпорируют в правовую систему нечто большее, чем просто толкование положений закона или конституции. Эти решения выводят из правовых или конституционных положений нормы, дополняющие конституционный и законодательный уровни правовой системы. Таким образом, они вносят, хотя и с ограничениями, отмеченными в настоящей работе, свой вклад в развитие правовой системы, разрешают конфрликты и устанавливают нормы, которые могут способствовать предотвращению новых споров. Тем самым они выполняют миротворческую функцию, которая свойственна любому правосудию.
\end{abstract}

Ключевые слова: конституционная юстиция, конституционные решения, судебное правотворчество, законодательство, источники права

Благодарности: Редакция выражает благодарность В. Е. Гидлевской за перевод текста с испанского языка, Е. Е. Рафралюк и А. Е. Кирпичеву за юридическую корректуру текста.

Для цитирования: Балагер Кальехон Ф. Нормотворческая фрункция конституционных решений // Правосудие/Justice. 2021. T. 3, № 1. C. 32-50. DOI: 10.37399/2686-9241.2021.1.3250. 


\title{
Normative Function of Constitutional Decisions
}

\author{
Francisco Balaguer Callejon \\ Universidad de Granada, Granada, Spain \\ For correspondence: balaguer@ugr.es
}

\begin{abstract}
Introduction. This work analyses the normative function of constitutional judgments, their characteristics and their limits.

Theoretical Basis. Methods. The theoretical bases start from the work of Hans Kelsen in relation to the condition of "negative legislator" of the constitutional court, which already implies a derogatory capacity on the legal order and, therefore, a normative function, completed with the differentiation of Vezio Crisafulli between "disposition and norm" that allows opening the constitutional jurisdiction to a consideration as "positive legislator". Likewise, theoretical contributions from other works by the author of the research are incorporated. The method that has been used to prepare the work is based on the analysis of the current legal reality of the constitutional jurisdiction taking into account the legal context in which it develops its functions.

Results. It is concluded that the normative function of constitutional judgments is a structural feature inherent to constitutional jurisdiction, which presents a series of specific characteristics. This normative function is characterized by being a complex reality, due to the diversity of procedures in which it occurs and the different legal material with which the constitutional jurisdiction works. It is also a complementary normative function, which lacks the plenitude of the legal production of law. Lastly, it is a fragmentary normative function, which operates on specific dispositions or provisions of the normative chains, without having the capacity to configure complete normative chains that correspond only to the legislator in the exercise of his legislative function.

Discussion and Conclusion. Constitutional decisions clearly develop a normative function, as they incorporate more into the legal system than just the interpretation of the provisions of the law or the Constitution. These decisions derive from legal or constitutional provisions norms that complement the constitutional and legislative levels of the legal system. Thus, they contribute, albeit with the limitations noted in this paper, to the development of the legal system, resolve conflicts and establish norms that can help prevent new disputes. Thus, they perform the peacekeeping function that is inherent in any justice.
\end{abstract}

Keywords: constitutional jurisdiction, constitutional judgments, jurisprudential production of law, legislation, sources of law

Acknowledgements. The editors are grateful to V. E. Gidlevskaya for the translation of the text from Spanish, E. E. Rafalyuk and A. E. Kirpichev for the legal proofreading of the text.

For citation: Balaguer Callejon, F., 2021. Normative function of constitutional decisions. Pravosudie/Justice, 3(1), pp. 32-50. DOI: 10.37399/2686-9241.2021.1.32-50.

\section{Введение}

\section{Предварительные методологические вопросы}

$\mathbf{B}$ настоящей статье будет проанализирована существующая связь между нормативным характером конституции и конституционной юстицией в соответствии с моделью конституционного правового государства многих европейских государств (в частности, Германии, Италии или Испании). Речь идет о системах концентрированной юрисдикции (с постепенным переходом к судебным полномочиям контроля, приближающим его к методам, характерным дмя диффузной юрисдикции [Zagrebelsky, G., 1992; Ruggeri A., 2019, p. 200], в которых формулировка сферы охвата и 
значения решений конституционных судов не всегда совпадает с характеристиками решений диффузной юрисдикции. Тем не менее была предпринята попытка придать этой работе теоретический и общий характер с тем, чтобы она могла быть полезна также в других контекстах дия понимания более конкретных нормотворческих аспектов конституционных решений.

\section{Теоретические основы. Методы}

Методология, на которой основана данная статья, явцяется строго юридической, основанной на фундаментальных доктринальных трудах таких авторов, как Ганс Кемьзен, Везио Крисафумли (Vezio Crisafulli) ими Алессандро Пиццоруссо (Alessandro Pizzorusso), дополненных собственными позициями автора из работ, связанными с источниками права, а также с формированием прецедентного права [Balaguer Callejón, F., 2000; Balaguer Callejón, F., 1991-1992; Balaguer Callejón, F., 2019]. Использованы и другие теоретические положения, разработанные по тематике данной работы. Вопрос о нормативной функции конституционных судебных решений требует предварительного обращения к доктринальным источникам, которые пропагандировали конституционную юстицию в Европе, а также к авторам, которые внесли свой вклад в разработку проблемы о проецировании юрисдикционной функции на систему источников права.

Основное внимание в настоящем исследовании уделяется нормотворческой функции решений конституционных судов. Это характерно дмя всех форм конституционной юстиции, поскольку посредством судебных решений не только осуществляется правосудие по конкретному делу, но и конституция толкуется таким образом, чтобы установить критерии, позволяющие определить нормы, которые должны применяться на основе конституционных положений. Определение значения конституционных положений предполагает, например, исключение норм, которые могми бы применяться государственной вцастью (вкАючая судей и суды) и которые не домжны применяться на основании решений конституционных судов.

Помимо этой основной функции, которую автор считает нормотворческой, размичные виды конституционных решений также обладают разным потенциалом воздействия на законы и всю правовую систему в цемом. С этой точки зрения не менее важно понимать потенциал конституционной юрисдикции в отношении правовых норм (или, что то же самое, взаимосвязь между конституционной юстицией и законодателем), поскольку она служит примером того, каким образом конституционная юстиция способствует развитию правовой системы, и предемы такого участия.

Существование конституционной юстиции, способной устанавцивать соответствие законов критерию конституционности, определяет существенное преобразование правового государства в конституционное пра- 


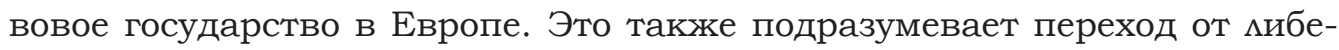
рального государства к социальному правовому государству, поскольку социальный договор, порождающий социальное государство, станет фундаментальным импульсом дмя преобразования конституции как нормативного свода, придающего единство правовой системе [Balaguer Callejón, F., 2016]. Территориальный и федеративный пакты не были достаточными в межвоенный период для закрепления конституционных норм, несмотря на попытки, предпринятые в этом отношении в некоторых европейских государствах [Cruz Villalón, P., 1987]. В настоящей статье будет проанализирована модець конституционного правового государства, которая делает возможными консолидацию конституционной юстиции и инкорпорацию нового источника нормотворчества в правовые системы стран, которые следуют этой конституционной модели.

\section{Резумьтаты исследования}

\section{Нормотвориеская функиия конституиионной юстииии}

Уже само существование конституционной юстиции и структурных усмовий ее функционирования, независимо от конкретной практики, заранее рассеивает сомнения относительно ее правотворческой способности. Если подобная дискуссия еще может иметь место в классическом понимании термина "контроць конституционности актов", то по отношению к нормоконтролю она невозможна. Что касается нормоконтроля, то правотворческая способность конституционных судов может обсуждаться в контексте того, как это традиционно демается в отношении юрисдикционной деятемьности судебной вцасти (хотя ответ может быть явно положитемьным).

Однако применительно к нормоконтролю эта дискуссия даже не возникает: каждый раз, когда конституционная юстиция выносит решение в отношении норм, подиежащих оценке, непосредственно затрагивается правовая система. Таким образом, поскольку основной функцией конституционного суда явцяется нормоконтромь ${ }^{4}$, можно утверждать, что одним из его предназначений является обновцяющий потенциал в отношении правовой системы, способность создавать право.

Оригинальная концепция конституционной юстиции, сформулированная Кемьзеном, позволяет нам прямо ответить на этот вопрос. По словам Кемьзена, отмена законодательного акта также явцяется законодательной функцией [Kelsen, Н., 1928, р. 197]. Когда судебный орган отменя-

4 Как отмечает А. Руджери, основная и наиболее квалифицирующая деятельность суда (вынесение суждений по законам и эквивалентные им действия) приводит к сравнению не между фактом и нормой, а между двумя нормами, в обоих случаях они способны оказывать общее воздействие; результатами явцяются последствия решений, принятых по итогам вышеупомянутого сопоставцения [Ruggeri, A., 2019, p. 195]. 
ет закон, он изменяет правовую систему, поэтому его инновационный потенциал неоспорим. Тот факт, что Кемьзен приписывает отменяющую функцию конституционной юстиции как "негативному законодателю", не означает, что она не обладает таким потенциалом дия инноваций. Отмена также является нормотворческой функцией: она вцечет за собой утрату действительности ранее существовавших норм и, следовательно, изменение содержащихся в них положений относительно прав и обязанностей, признаваемых правовой системой.

К этой нормотворческой функции Кемьзеном добавляется функция "позитивного законодателя" конституционной юстиции, реализуемая на практике посредством воздействия на формулировки правовых норм, которые устанавциваются нормативно, с определением конкретного значения, в котором они могут применяться в качестве соответствующих конституции. В этом отношении проведенное Крисафумли разграничение между "положением" и "нормой" разъясняет этот статус конституционной юстиции как законодателя, но уже не негативного, который "отменяет" правовые нормы, а позитивного, который дополняет правовые формулировки, наделяя их конкретным нормативным содержанием [Crisafulli, V., 1964].

С другой стороны, если учесть эффективность позиций, выработанных в решениях конституционных судов, можно сказать, что их обновмяющий потенциал проявцяется не только в случае подтверждения актов нижестоящих судов, но и при принятии решений об их отмене. Действительно, после того как конституционная юстиция постановила о соответствии рассматриваемого закона конституции, она также определила сферу действия законодателя в конституционных рамках. С этой точки зрения решение конституционного суда выполняет специфическую нормотворческую функцию.

\section{Характеристики нормотворческой функиии решений конституиионных судов}

\section{1. Комплексность}

Таким образом, рассматривая нормотворческую функцию решений конституционных судов как имманентно присущую конституционной юстиции, необходимо затронуть вопрос об особенностях этой формы нормотворчества. Поэтому речь идет об определении сферы охвата данной нормотворческой функцией и ее взаимосвязей с другими органами, такими как законодатель, и ее вциянии на формирование правовой системы.

Первый вопрос, который необходимо решить, связан с факторами, обусловливающими такое нормотворчество. В первую очередь это касается юридического материала, с которым работает конституционная юстиция. Обсуждение нормотворческой функции решений конституционных судов в общем смысле не должно приводить к недифференцированной 
оценке разцичных видов норм, в отношении которых осуществцяется конституционный контроль.

Таким образом, когда в решении органа конституционной юстиции демается вывод относительно конституционности закона, в качестве нормативного материала рассматриваются как конституция, которая служит ориентиром, так и закон, подлежащий юридической оценке. Взаимосвязь конституционной юстиции с обоими типами норм очевидно разцична.

Первичный правовой материал, который должен использоваться конституционными судами, состоит из конституционных положений ${ }^{5}$, а вторичный материал - из подконституционных норм. Подобная дифференциация не искцючает того факта, что подконституционные нормы могут также вкцючать в некоторых случаях критерий конституционности, как это происходит при косвенном конституционном контроле.

Таким образом, конституционное решение развивает свою нормотворческую функцию, обновляя правовую систему на всех ее уровнях, не только на законодательном, но на и конституционном уровне. Такая дифференциация домжна обязательно учитываться при анализе особенностей правотворчества конституционных судов. Например, предемы правовых инноваций, которые могут вступать в противоречие с конституционной юрисдикцией на законодательном уровне, не обязательно совпадают с предемами, действующими на конституционном уровне.

Тип процесса также явцяется фактором, который необходимо принимать во внимание, так как нормотворческая функция не имеет той же сферы охвата в процессе оценки конституционности норм, как в процедуре ампаро ${ }^{6}$ (в правовой системе Германии ими Испании) ими в процессах, в рамках которых разрешаются конфцикты компетенции. Даже в последнем случае иногда отказывались от обновляющего потенциала решений конституционных судов. Безусловно, такой подход может быть поставцен под сомнение, если он основывается на том, что конституционная юстиция ограничивается признанием полномочий, которые уже закрепцены конституционным порядком.

Однако следует иметь в виду, что конституционная юстиция здесь вносит изменения как в отношении первичного материала (самой конституции), так и в отношении вторичного материала (норм, которые являются объектами контроля). Применительно к вторичному материалу - не только потому, что разрешение комлизии компетенций может привести к аннулированию норм (что уже оказывает нормативное воздействие на

5 Мы не вдаемся в подробности по вопросу расширения параметра конституционности в связи с наднациональным правом, и в частности правом Евросоюза. По этим вопросам см. [Balager Callejón, F., 2017].

6 Процедура ампаро - это средство защиты конституционных прав граждан путем подачи жалобы непосредственно в Конституционный Суд. Распространена в испаноязычных государствах, а также в ФРГ. 
систему), но и прежде всего потому, что данное решение требует общей регулятивной деятельности конституционной юстиции в момент установмения критериев, на которых основывается разграничение осуществцяемой компетенции. Такая регулятивная деятельность может иметь большое значение дмя правовой системы.

С точки зрения толкования конституции тип процесса может вциять на то, каким образом решение конституционного суда вносит допомнительные правила в конституционные положения. Например, в процедурах контроля конституционности законов и ампаро (в конституционных системах, в которых предусматривается соответствующий тип процесса).

Не искцючено, что решение относительно вторичного материала влияет также на толкование первичного материала. Заявмение о неконституционности того ими иного закона может оказать большое влияние на правовую систему, и конституционная юстиция не отвергает эту возможность во время рассмотрения дела по вопросу о конституционности. Необходимость избегать пробелов в правовой системе, когда судебное решение затрагивает законодатемьные положения, аннулирование которых привело бы к возникновению пробела, который не может быть восполнен конституционной судебной практикой, - это то, что необходимо оценивать в момент вынесения решения ${ }^{7}$.

Разнообразие процессов, в рамках которых конституционная юстиция домжна выносить свои постановления, неизбежно сказывается на нормотворческой функции судебных решений. Ценность решений конституционных судов обязательно связана с тем типом процесса, в котором они выносятся, по крайней мере в отношении вторичного материала, который они используют и который явцяется предметом контроля конституционности.

В процессах, в которых признается неконституционность того или иного закона, правовая система преобразуется, поскоцьку отменяется норма, которая ранее устанавливала права и обязанности, или она изменяется путем определения ее конституционно корректного значения. После вынесения решения, как это было бы в случае принятия нового закона, отменяющего предыдущий закон, эти права и обязанности прекращают свое существование или приобретают новый смысл. Этого не происходит, когда решается демо, в ходе которого решение неизбежно имеет последствия в отношениях inter partes, например, в ходатайстве об ампаро или других конституционных процессах такой природы.

В этой связи весьма полезным является критерий, использованный А^ессандро Пиццоруссо для определения источников права, основанный

7 Хотя в некоторых случаях конституционная юрисдикция может принимать спорные решения при том понимании, что будут образовываться пробелы там, где дмя их предотвращения достаточно прямого применения конституционных положений. См.: [Balager Callejón, F., 2018]. 
на идее о том, что, поскоцьку источники права создают правовые нормы, средство их идентификации заключается в определении того, что следует понимать под правовыми нормами. Существенным вопросом в этом отношении является не столько определение характера нормы, которое вводится в правовую систему с помощью источника (общность, абстракция, инновационная способность и т. д.), сколько определение того, обмадает ми эта норма способностью создавать эффект erga omnes или нет. Таким образом, можно сказать, что источниками права явцяются только те, которые устанавцивают нормы, которые обладают характером erga omnes, в отношении всех субъектов правовой системы (хотя они не обязательно применимы к каждому из этих субъектов). Правовые акты, которые устанавцивают нормы, эффективно действуют inter partes [Pizzorusso, A., 1977, p. 15].

Естественно, это разграничение не затрагивает первичный материал, собственно параметр конституционности, поскольку это образует часть конституционной юстиции. Толкование конституции и нормативной структуры конституционных формулировок или положений всегда по своей природе действует erga omnes, поскольку оно связывает все виды государственной вцасти, а не только те, которые участвовали в конституционном процессе.

\section{2. Дополняюший характер}

В отношении законодателя нормотворческая функция решений конституционных судов проявляет специфические характеристики. Действительно, можно сказать, что правотворчеству на уровне судебной практики присуща общая черта: судебное правотворчество не имеет той полноты, что свойственна законотворчеству. Закон продолжает оставаться инструментом формирования правовой системы, которая представцяет собой нормальное функционирование механизмов создания права. Судебная практика обладает корректирующим потенциалом, который возникает только в момент разрешения конфцикта.

Таким образом, судебная практика является дополнительным (комплементарным) источником создания правовой системы. Что касается судебной практики Верховного Суда Испании, то в Гражданском кодексе Испании установлено следующее: “Судебная практика дополняет правовую систему поможениями, которые неоднократно устанавцивает Верховный Суд при толковании и применении законов, обычаев и общих принципов права" (ст. 1.6). Источник, который играет определенную роль только тогда, когда происходит осуществцение юрисдикционной функции.

С точки зрения традиционного статического рассмотрения правовой системы можно сказать, что судебная практика выражает реакцию на патологию системы. С позиции обычных механизмов правотворчества судебная практика как источник права проявцяется только тогда, когда 
по тем или иным причинам в этих обычных механизмах имеет место некоторый сбой, когда возникает правовой конфиикт, требующий судебного решения. Дело в том, что эта "патология" так же распространена в законодательстве, как и болезнь в мюбом обществе. Реакция на нее, которую создает судебная практика, явцяется жизненно важным механизмом дия развития правовой системы.

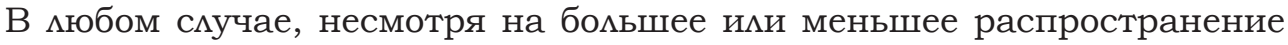
судебной практики как источника права, и в частности практики конституционного суда, эта особенность, выражающаяся во взаимодопоцняющем характере, не может считаться несущественной. Она оказывает значимое влияние как на согласование разцичных источников права, так и на изменение самой правовой деятемьности.

Что касается последнего: в симу характера судебной практики необходимо учитывать, что судебное решение никогда не может заменить собой закон. Судебная практика конституционных судов выполняет корректирующую или восстановительную функцию, которая не соответствует формированию законности на уровне полноты, в которой эта функция принадлежит законодатемьству. Это ограничение правовой деятемьности конституционной юрисдикции имеет четкую связь со смыслом демократического принципа, межащего в основе нормативной конституции.

В качестве выражения демократической воли общества, сформированной в соответствии с формальными механизмами проявления плюрамизма, закрепленными в конституции, закон обладает структурной способностью формировать правовую систему. Однако эта способность к формированию может быть подкорректирована конституционной юстицией, если формальные механизмы выражения плюрализма не служат гарантией соблюдения конституционного порядка. Если же законодатемьная демократия противоречит конституционной демократии и законодательство нарушает конституционные принципы, тогда конституционная юстиция может осуществцять пересмотр законодатемьных мер. Этот пересмотр допускает разцичные формулировки в соответствии с требованиями, вытекающими из необходимого согласования конституционных принципов (которыми выступают плюрализм и принцип конституционности как еще одна возможность дия согласования). В мюбом случае сама конституционная юстиция должна сохранять канал плюрализма открытым, избегая толкования, которое могло бы его ограничить.

Нормотворческая функция решения конституционного суда осуществляется в процессе контроля, и об этом ограничении никогда нецьзя забывать. Законодатель домжен устанавливать нормы, а конституционная юстиция - контролировать эти нормы. Нормотворчество в рамках конституционной юстиции может осуществцяться только в рамках ее контрольной функции. Конституционная юстиция является не органом создания права, а органом контроля, создающим право в результате этой контрольной деятельности. 
Взаимосвязь между конституционной юстицией и конституцией возникает по-другому. Безусловно, развитие нормотворческого потенциала конституционной юстиции происходит и при осуществлении ею своей юрисдикционной функции. Однако потенциал для ее действий шире. Например, согласно законодательству Испании конституционная юстиция не может распространять заявмение о неконституционности и недействительности правовых норм за пределы текста закона, подмежащего юридической оценке, но она может основывать вывод о неконституционно-

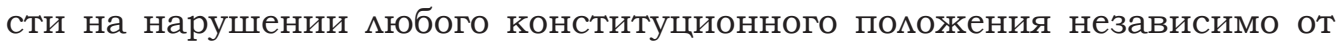
того, было оно применено в этом процессе или нет.

С другой стороны, поскоцьку естественной функцией конституционной юстиции является окончательное толкование конституционных поможений, ее возможности по формированию конституционного порядка весьма значительны. По этой причине нормотворческая функция решений конституционного суда проявцяется более интенсивно, когда она определяет нормативное значение конституционных положений.

\section{3. Фрагментарность}

В техническом плане комплементарный характер судебной практики, будь то обычная или конституционная, проявцяется в том, как формируются нормативные цепочки, которые в конечном итоге будут применяться субъектами права. Законодатель может, исходя из конституционных рамок, установить полную цепочку формулировок, применимых субъектами права. Такие полномочия присущи демократическому принципу, межащему в основе конституционного строя.

Напротив, нормотворческая функция решений конституционного суда действует только при корректировке или согласовании некоторых формумировок нормативной цепочки, которые были поставцены под сомнение, или тех, которые требуют своей собственной формулировки (поскольку их не существует и необходимо обратиться к механизмам системной интеграции) или приведения в соответствие с принципами системы.

Фрагментарное вмешательство конституционных судов в законы может предполагать, что некоторые правовые положения исключаются из законодательства, поскольку нормы, которые из них могут быть выведены, противоречат конституции. В других случаях суды могут устанавАивать, что нормы соответствуют конституции, основываясь на соответствующих правовых положениях. В таких случаях из этих формулировок могут исключаться нормы, соответствующие конституции, отличные от оспоренных, что исключает некоторые нормативно-правовые формулировки, поскольку они противоречат тексту конституции или вынуждают применять определенные формулировки, чтобы правовые положения рассматривались в соответствии с конституцией.

Например, когда в решении устанавливается, что определенная правовая норма соответствует конституции, при условии, что она толкуется 
так, как она определена в конкретной правовой основе самого решения (или при условии, что исключается определенное толкование, содержащееся в правовой основе решения), то такое правовое положение согласуется с конституцией. С этой целью данное положение формулируется в качестве нормы, которая отмичается от той, на которую ссылаются заявители на основании того же правового положения. В результате с этого момента закон не может применяться без испоцьзования конституционного решения, в котором сформулирована действующая норма, вытекающая из правового положения ${ }^{8}$.

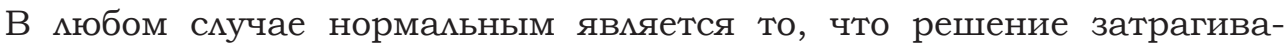
ет только одно или несколько правовых предписаний. За искцючением определенных условий (например, когда отменяется норма или нормы о компетенции объявляются неконституционными), применение судебной практики носит ограниченный характер и касается конкретных положений, которые явцяются частью более системного комплекса. Это предпомагает, что способность практики напрямую вциять на неконституционное законодательство на самом деле очень ограничена, хотя эти решения могут иметь очень важное политическое воздействие.

Такое воздействие явцяется следствием третейского характера конституционной судебной практики и политической напряженности, межащей в основе конституционных процессов. Однако законодательная функиия, развиваемая конституционной юстицией через ее решения, не явцяется подиинно законодатемьной функцией, подобной той, которую выпоцняет законодатель, который выражает волю, объединяющую все нормативно-правовые элементы, необходимые дмя регулирования определенной социальной сферы.

Законодательство не всегда унитарно (например, в федеративных и политически децентрализованных государствах или в наднациональных интеграционных образованиях). Однако законодательная функция обычно основывается или домжна основываться на планировании на всех его этапах даже за пределами юрисдикционного вмешательства.

В целом можно сказать, что, в то время как законодатецьство стремится к полным нормативно-правовым формулировкам, конституционная юрисдикция имеет тенденцию оценивать положения или нормы, которые будут применяться только в нормативно-правовых контекстах, ранее опредеменных законодатемем.

Можно было бы по-другому оценить взаимосвязь между конституционной юстицией и конституцией. Вкмад конституционной юстиции в создание конституционного права также осуществцяется в рамках предварительного нормативного плана. Однако в данном случае потенциал воздействия конституционных решений выше, а их вмешательство менее фрагментарно.

8 О разграничении положения и нормы см.: [Crisafulli, V., 1964]. 
Действительно, юрисдикционная деятельность здесь проводится в весьма ограниченном контексте и в отношении положений, которые могут быть сформулированы в качестве норм прямого применения для их адресатов. Когда в решении конкретизируются такие положения - это проявцение законодательной функции в деятельности судов. Изменение значения при толковании конституционными судами (т. е. выработка новых норм на основе тех же конституционных положений) может привести к непредвиденным последствиям.

В то же время способность формировать подконституционный порядок, который конституционная юстиция может обеспечить путем создания конституционного права в своих решениях (параконституционные нормы, созданные судебной практикой), намного превосходит способность, которую она может сформулировать посредством фрагментарного подконституционного правотворчества.

\section{Границы нормотворческой функции конституционных решений}

\section{1. Демократический приниип как гранииа и легитимаиия}

Демократический принцип действует не только как ограничение, но и как мегитимация нормотворческой функции конституционных решений. Подобная двойственность объясняется амбивалентностью, характерной дия демократического принципа. С одной стороны, демократический принцип поддерживает законодательные нормы и наделяет их презумпцией конституционности. Конституционная юрисдикция не может игнорировать демократический характер законодатемьной вмасти. С другой стороны, поскольку речь идет о конституционной демократии, плюралистической демократии, демократический принцип как бы узаконивает вмешательство конституционной юстиции.

Если бы демократический принцип рассматривался искАючительно в трактовке демократии как воли большинства, то само существование конституционной юстиции было бы бессмысленным. Эта концепция демократии была концепцией первого конституционализма, свойственной олигархическому миберализму [Zagrebelsky, G., 1988, pp. 9-10], дмя которого не было необходимости в нормативности конституции ввиду однородности социальных групп, имеющих доступ к политическому пространству, и она была невозможна из-за отсутствия плюрализма.

Именно сложное понимание демократии как предпочтения большинства и уважения меньшинств - как плюралистической демократии в цемом - позволяет проводить разцичие между конституционным и законодательным уровнями в правотворчестве и контроле на законодательном уровне на основе конституционных критериев. Когда конституционализм сформулирован в качестве подиинного конституционного права в соответствии с нормативной Конституцией, а демократия рассматривается как плюралистическая демократия или конституционная демократия, 
контроль конституционности законодательства становится возможным. Таким образом, подобный контроль обладает явной демократической $е$ гитимацией, поскольку именно он делает возможной эту концепцию демократии, единственную концепцию, которая совместима с конституционным наследием сегодня.

Поэтому проблема демократической мегитимации обычной юстиции в рамках верховенства права (в системах концентрированной конституционной юрисдикции) здесь не поднимается, она действует на ином уровне. В то время как конституционная юстиция действует на конституционном уровне обеспечения плюралистической демократии, обычная юстиция действует на подконституционном уровне, на правовом уровне выражения большинства. Таким образом, на конституционную юстицию не оказывают вцияния ограничения, которые могут быть отнесены к обычной юстиции, поскоцьку в тех случаях, когда конституционная юстиция осуществцяет правотворчество на подконституционном уровне - в результате контроля, осуществляемого ею на этом уровне, она выполняет соответствующую ей функцию.

Иная ситуация - нормотворчество на конституционном уровне. Можно было бы считать, что в отношении конституции конституционная юстиция имеет право только "толковать" ее положения, но не развивать или нормативно закреплять конституционные предписания. Между тем конституционная юстиция выполняет эту задачу, поскоцьку конституционные решения могут вциять на текст конституции, с которым они связаны.

Неотьемлемой частью нормотворческой функции, которую осуществАяют конституционные суды, является определение норм, которые могут быть искАючены из конституционных положений, а также норм, которые противоречат конституционным положениям. Подчинение конституции самой конституционной юстиции не противоречит осуществцению собственно нормотворческой функции. Эта функция носит третейский характер и позволяет установить не единственно возможное решение правовых проблем (поскоцьку, как указал Кецьзен, попытка установить един-

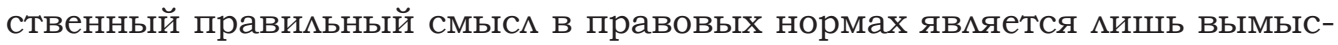
мом, призванным поддерживать идеал определенности права [Kelsen, H., 1960, р. 353], а решение обоснованное и аргументированное, способное обеспечить консенсус его адресатов.

\section{2. Разделение властей}

Раздемение властей в качестве ограничения нормотворческой функции решений конституционных судов является достаточно сложным вопросом, учитывая, что конституционная юстиция выполняет именно функцию контроля над другими государственными вцастями. С этой точки зрения трудно охарактеризовать раздемение вцастей как самостоятельный ограничитель за рамками, обусловленными структурными осо- 
бенностями юрисдикционной функции и соблюдением других конституционных принципов.

Следует также иметь в виду, что конституционная юстиция призвана устанавливать конкретные границы разделения вцастей, и с этой точки зрения конституционная юрисдикция находится на более высоком уровне, чем принцип разделения вцастей. Скорее конституционная юстиция обеспечивает внешнее или правовое разделение властей как орган, который не интегрирован ни в одну из трех традиционных ветвей государственной вцасти и который контролирует предемы компетенции каждой из них [Balaguer Callejón, F., 1991, p. 189].

В связи с этим возникает вопрос о конкретной сфере функции конституционной юстиции и ее границах, о которых мы уже говорили ранее: должно $и$ существовать также самоограничение конституционной юстиции для облегчения участия законодателя в процессах юридического согласования законов? С данной точки зрения существует вероятность того, что конституционная юстиция будет направлена на самого законодателя, чтобы последний имел возможность исправить признаки неконституционности [Jiménez Campo, J., 1998, p. 171]. Эта вероятность, несомненно, учитывает возможности юридической формы, которая соответствуют законодательству. Это не означает, что вариант, предложенный решением самого конституционного суда, не принимается во внимание законодателем, поскольку законодатель всегда может внести изменения в закон, чтобы в необходимой мере адаптировать его к решению суда или чтобы принять иное решение, если оно соответствует критериям, уста-

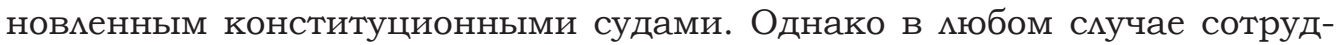
ничество между конституционным судом и законодателем в целях совершенствования правовой системы [Jiménez Campo, J., 1998] представцяется вполне целесообразным.

\section{Обсуждение и закмючение}

\section{Нормативная иенность конституиионных решений}

Когда решениями конституционного суда определяются пределы нормативных возможностей разцичных источников права, они осуществляют деятельность по обновлению системы права, которая, несомненно, выступает стержнем функции, выполняемой конституционной юстицией. Как мы уже отмечали, это проявляется двояко: решение подтверждает конституционность как самой конституции, так и вторичного материала, явмяющегося объектом оценки, действительность норм в рамках законодательства. В обоих случаях нормотворческая функция решений конституционного суда реализуется посредством правовых норм, основанных на положениях, содержащихся в текстах, которые должны использоваться в качестве параметра или объекта контроля. Однако сформулированные в 
каждом конкретном решении нормы обладают разным нормативным потенциалом, что свидетельствует о сложности работы, выполняемой конституционной юстицией.

Толкование конституционными судами конституционного текста может породить изменение конфигурации параконституционных норм, конституционных норм, созданных судебной практикой. Эти нормы выступают критерием, на основании которого конституционная юстиция осуществляет контроль конституционности деятемьности публичных вцастей.

Однако это не единственные нормы, которые конституционные суды могут сформулировать на основе положений, используемых ими дмя выполнения своей функции. Это позволяет сдемать вывод о том, что этими материальными конституционными нормами не исчерпывается вопрос о нормативной значимости решений конституционной юстиции.

Одно и то же решение конституционного суда может иметь разцичный правовой режим в отношении нормативных актов, включенных в него: резолютивная часть решения, содержащая правовые новемлы, связывает правовой режим с нормой ими рассматриваемым актом. Напротив, правовые основания меняются в зависимости от того, обусловцены ми установ енные в них нормы толкованием первичного или вторичного материала. В первом случае позиция уже обозначена как по существу конституционная. Во втором случае нужно исходить из толкования самого вторичного материала.

Нормотворческая функция решений конституционного суда обеспечивает бонус (plus) правовым нормам, которые явцяются объектом юридической оценки: это всегда нормотворчество, связанное с конституцией; и всегда, по крайней мере формально, обязательная выработка норм с конституционной точки зрения. Это означает, что законодатець или обычные суды связаны этим правотворчеством, а не своими собственными предыдущими решениями и, следовательно, ценность решений конституционной юрисдикции в этом смысле выше, чем правовых положений, которые она обновцяет.

Следует иметь в виду, что мюбой судебный процесс подразумевает правовой конфмикт, который судебное решение домжно урегулировать. Поскоцьку конфцикт возникает в связи с высшим - конституционным - правом, решение проблемы должно также придерживаться этого высшего права, устанавцивая тем самым особую связь государственных органов в отношении нормотворческой функции, развитой решениями конституционного суда.

Следовательно, хотя законодатель может свободно изменять свои собственные нормы, он не может, однако, изменять их так, чтобы это противоречимо конституционной судебной практике. Таким образом, обычная нормотворческая функция обусловлена нормотворческой функцией, развитой решениями конституционного суда, поскольку они 
определяют конституционные рамки деятемьности законодатецьной власти.

В общих чертах доктрина ссылается на такую связь, используя выражение "решения о толковании", подразумевая решения, которые предусматривают обязательное толкование нормативного материала, оцениваемого конституционной юстицией, в частности закона.

Сохранение формалистической концепции однозначно связано с использованием формулировки, по-видимому, вновь сводящей функцию судьи к простому изцожению существующего права. Хотя все решения конституционных судов являются решениями о толковании, поскольку все они обязательно толкуют первичный материал (конституцию) и вторичный материал (норму или рассматриваемый акт), некоторые из них являются также нормативными решениями, которые включают обязательные для исполнения правовые нормы [Silvestri, G., 1985].

Решения конституционного суда очевидно развивают нормативную функцию [Balaguer Callejón, F., 2000; Balaguer Callejón, F., 1991-1992; Balaguer Callejón, F., 2019], поскоцьку они инкорпорируют в правовую систему нечто большее, чем просто толкование положений закона или конституции. Эти решения выводят из правовых или конституционных положений нормы, дополняющие конституционный и законодательный уровни правовой системы. Таким образом, они вносят, хотя и с ограничениями, отмеченными в настоящей работе, свой вклад в развитие правовой системы, разрешают конфцикты и устанавливают нормы, которые могут способствовать предотвращению новых споров. Тем самым они выполняют миротворческую функцию, которая свойственна мюбому правосудию.

\section{Список использованной Аитературы}

Balaguer Callejón F. (coord.), Cámara Villar G., López Aguilar J. F., Balaguer Callejón M. L., Montilla Martos J. A. Manual de Derecho Constitucional. 14 ${ }^{\mathrm{a}}$ ed., dos volúmenes. Madrid : Tecnos, 2019. 528 p.

Balaguer Callejón F. Fuentes del Derecho Madrid : Tecnos, 1991-1992. T. I-II.

Balaguer Callejón F. Il contenuto essenziale dei diritti costituzionali e il regime giuridico dell'immigrazione in Spagna // Rassegna di Diritto Pubblico Europeo. 2018. T. XVII, no. 1. P. 33-60.

Balaguer Callejón F. La dimensione costituzionale dello Stato sociale di Diritto / / Studi in onore di Francesco Gabriele / a cura di A. M. Nico. Bari : Cacucci Editore, 2016. P. 1-22.

Balaguer Callejón F. Notas sobre la estructura constitucional del Estado Español // Revista de Derecho Político. 1991. No. 32. P. 189-220. 
Balaguer Callejón F. Primato del diritto europeo e identità costituzionale nell'esperienza spagnola // I Controlimiti - Primato delle norme europee e difesa dei principi costituzionali / a cura di A. Bernardi. Napoli : Jovene Editore, 2017. P. 113-133.

Balaguer Callejón F. Tribunal Constitucional y creación del Derecho // La justicia constitucional en el Estado democrático / coords. E. Espín Templado y F. J. Díaz Revorio. Valencia : Tirant lo Blanch, 2000. P. 381-395.

Crisafulli V. Disposizione (e norma) // EdD. 1964. T. XIII.

Cruz Villalón P. La formación del sistema europeo de control de constitucionalidad (1918-1939). Madrid : CEC, 1987.

Jiménez Campo J. Sobre los límites del control de constitucionalidad de la ley / / Las tensiones entre la jurisdicción constitucional y el legislador en la Europa actual / ed. E. Aja. Barcelona : Ed. Ariel, 1998.

Kelsen H. La garantie juridictionnelle de la Constitution (La Justice constitutionnelle) // Revue du Droit Public. 1928. T. XLV.

Kelsen H. Reine Rechtslehre. 2. Aufl. Viena : Verlag Franz Deuticke, 1960 (reimpresión de 1967).

Pizzorusso A. Delle Fonti del Diritto. Commentario del Codice Civile, Art. 1-9 / ed. N. Zanichelli. Bologna ; Roma : Soc. Ed. Del Foro Italiano, 1977. XLV, 597 p.

Ruggeri A. Trasformazioni della Costituzione e trasformazioni della giustizia costituzionale / "Itinerari" di una ricerca sul sistema delle fonti. XXII. Studi dell'anno 2018. Torino : Giappichelli editore, 2019. 832 p.

Silvestri G. Le sentenze normative della Corte costituzionale // Scritti in Onore di Vezio Crisafulli. Vol. I. Scritti su la Giustizia costituzionale. Padova: Cedam, 1985. XXXI, 822 p.

Zagrebelsky G. Il diritto mite. Torino : Einaudi, 1992. IX, 218 p.

Zagrebelsky G. Manuale di Diritto costituzionale. Vol. I. Il sistema delle fonti del diritto. Torino : UTET, 1988. 324 p.

\section{References}

Balaguer Callejón, F., 1991. Notas sobre la estructura constitucional del Estado Español. Revista de Derecho Politico, 32, pp. 189-220.

Balaguer Callejón, F., 1991-1992. Fuentes del Derecho Madrid: Tecnos. T. I-II.

Balaguer Callejón, F., 2000. Tribunal Constitucional y creación del Derecho. In: E. Espín Templado and F. J. Diaz Revorio, coords. La justicia constitucional en el Estado democrático. Valencia: Tirant lo Blanch. Pp. 381-395. 
Balaguer Callejón, F., 2016. La dimensione costituzionale dello Stato sociale di Diritto. In: A. M. Nico, ed. Studi in onore di Francesco Gabriele. Bari: Cacucci Editore. Pp. 1-22.

Balaguer Callejón, F., 2017. Primato del diritto europeo e identità costituzionale nell'esperienza spagnola. In: A. Bernardi, ed. I Controlimiti Primato delle norme europee e difesa dei principi costituzionali. Napoli: Jovene Editore. Pp. 113-133.

Balaguer Callejón, F., 2018. Il contenuto essenziale dei diritti costituzionali e il regime giuridico dell'immigrazione in Spagna. Rassegna di Diritto Pubblico Europeo, XVII(1), pp. 33-60.

Balaguer Callejón, F., (coord.), Cámara Villar, G., López Aguilar, J. F, Balaguer Callejón, M. L. and Montilla Martos, J. A., 2019. Manual de Derecho Constitucional. $14^{a}$ edición, dos volúmenes. Madrid: Tecnos.

Crisafulli, V., 1964. Disposizione (e norma). EdD, XIII.

Cruz Villalón, P., 1987. La formación del sistema europeo de control de constitucionalidad (1918-1939). Madrid: CEC.

Jiménez Campo, J., 1998. Sobre los límites del control de constitucionalidad de la ley. In: E. Aja, ed. Las tensiones entre la jurisdicción constitucional y el legislador en la Europa actual. Barcelona: Ed. Ariel.

Kelsen, H., 1928. La garantie juridictionnelle de la Constitution (La Justice constitutionnelle). Revue du Droit Public, XLV.

Kelsen, H., 1960. Reine Rechtslehre. 2. Aufl. Viena: Verlag Franz Deuticke (reimpresión de 1967).

Pizzorusso, A., 1977. Delle Fonti del Diritto. Commentario del Codice Civile, Art. 1-9. Ed. N. Zanichelli. Bologna; Roma: Soc. Ed. Del Foro Italiano. Ruggeri, A., 2019. Trasformazioni della Costituzione e trasformazioni della giustizia costituzionale. "Itinerari" di una ricerca sul sistema delle fonti. XXII. Studi dell'anno 2018. Torino: Giappichelli editore.

Silvestri, G., 1985. Le sentenze normative della Corte costituzionale. Scritti in Onore di Vezio Crisafulli. Volume I. Scritti su la Giustizia costituzionale. Padova: Cedam.

Zagrebelsky, G., 1992. Il diritto mite. Torino: Einaudi.

Zagrebelsky, G., 1988. Manuale di Diritto costituzionale. Volume I. Il sistema delle fonti del diritto. Torino: UTET. 


\section{Информация об авторе / Information about the author}

Балагер Камьехон Франциско, доктор права, профессор, профессор кафедры конституционного права Университета Гранады (Испания, 18001, Гранада, Университетская пц., д. 1, юридический факультет)

Francisco Balaguer Callejón, Doctor of Law, Professor, Professor of the Constitutional Law Department, University of Granada (Faculty of Law, 1, Plaza de la Universidad, Granada, 18001, Spain).

Email: balaguer@ugr.es

Дата поступления рукописи на испанском языке в редакцию издания: 11.02.2020; дата одобрения после рецензирования: 25.01.2021; дата принятия статьи к опубликованию: 02.02.2021.

Submitted 11.02.2020; reviewed 25.01.2021; revised 02.02.2021. 
UDC 343.21

DOI: $10.37399 / 2686-9241.2021 .1 .51-68$

\title{
The Social Significance of the Regulation of Non-Criminal Acts in the Criminal Law
}

\author{
Denis A. Garbatovich \\ Ural Branch, Russian State University of Justice, Chelyabinsk, Russian \\ Federation \\ For correspondence: garbatovich@mail.ru
}

\begin{abstract}
Introduction. In science, it is already proved that the effectiveness of criminal legislation in relation to crime prevention is very limited. The criminal law is objectively unable to eliminate the causes of crime due to their social nature. Nevertheless, the regulation of non-criminal acts is a socially significant area of criminal law policy that helps to resolve or reduce the painful difficulties that arise in the process of law-making and law enforcement activities in relation to the criminal law. Theoretical Basis. Methods. The theoretical basis of the research is based on Russian doctrinal sources devoted to modern concepts of criminal policy, forms and means of its implementation, and the social consequences of mitigating or toughening criminal repression.

Results. The social importance of the regulation of non-criminal legal acts is determined by the ability to resolve three central problems. Firstly law-making activities when determining the boundaries of criminalisation. Secondly, maintaining human resources to implement repressive penal policy. Thirdly conservation of the economic resource, as the impact of penal policy and define ensuring the principle of inevitability of criminal responsibility and alternative ways to resolve a criminal law conflict. This includes the possibility of self-defense of individual rights by means of criminal law.

Discussion and Conclusion. Regulation of non-criminal acts is a kind of "safety mechanism" of criminal law policy. It is a means of protection against excessive criminalisation, a means of ensuring compliance of legislative formulas with the realities of life, and a means of ensuring a balance between lawmaking and law enforcement.
\end{abstract}

Keywords: criminal policy, non-criminal legal acts, criminal repression, law-making, criminal responsibility, compliance, criminalisation, penal policy, criminal law conflict

For citation: Garbatovich, D. A., 2021. The social significance of the regulation of non-criminal acts in the criminal law. Pravosudie/Justice, 3(1), pp. 51-68. DOI: 10.37399/26869241.2021.1.51-68. 


\title{
Социальная значимость регламентации непреступных уголовно-правовых деяний
}

\author{
Д. А. Гарбатович \\ Уральский филиал Российского государственного университета \\ правосудия, г. Челябинск, Российская Федерация \\ garbatovich@mail.ru
}

\begin{abstract}
Аннотация
Введение. В науке доказано, что эффрективность средств уголовного законодательства относительно предупреждения преступности является весьма ограниченной. Уголовный закон объективно не способен ликвидировать причины преступности в силу их социальной природы. Тем не менее регламентация непреступных уголовно-правовых деяний является социально значимым направлением уголовно-правовой политики, способствующим разрешению или снижению болезненности проблем, возникающих в процессе правотворческой и правоприменительной деятельности относительно уголовного закона.

Теоретические основы. Методы. Теоретической основой исследования стали отечественные доктринальные источники, посвященные современным концепциям уголовной политики, формам и средствам ее реализации, социальным последствиям смягчения или ужесточения уголовной репрессии.

Результаты исследования. Социальная значимость регламентации непреступных уголовно-правовых деяний определяется способностью разрешить проблемы: 1) правотворческой деятельности при установлении границ криминализации; 2) сохранения человеческого ресурса при реализации репрессивной уголовно-правовой политики; 3) сохранения экономического ресурса как последствия уголовно-правовой политики; 4) обеспечения принципа неотвратимости уголовной ответственности и определить возможности разрешения уголовно-правового конфрликта альтернативным способом и самозащиты прав личности средствами уголовного закона.

Обсуждение и заключение. Регламентация непреступных уголовно-правовых деяний представляет собой некий «страховочный механизм» уголовно-правовой политики, средство защиты от избыточной криминализации, средство обеспечения соответствия законодательных формул жизненным реалиям, средство обеспечения баланса между законотворчеством и правоприменением.
\end{abstract}

Ключевые слова: уголовная политика, непреступные уголовно-правовые деяния, уголовная репрессия, уголовная ответственность

Для цитирования: Гарбатович Д. А. Социальная значимость регламентации непреступных уголовно-правовых деяний // Правосудие/Justice. 2021. Т. 3, № 1. С. 51-68. DOI: 10.37399/2686-9241.2021.1.51-68.

\section{Introduction}

In the process of fulfilling its social purpose of satisfying the relevant needs of society, the ability of the criminal law to achieve its goals through the criminal law means at its disposal is relatively effective. In the theory of criminal law, criminological research, as well as in the practice of applying the criminal law when imposing punishment, it has long been established that its restorative, general and private preventive, corrective functions are extremely small [Karpets, I. I., 1973; Gilinsky, Ya. I., 2015, p. 39; Babaev, M. M. and Pudovochkin, Yu. E., 2015], the reasons giving rise to crime as a social phenomenon have a social nature and cannot be eliminated by the criminal law 
due to its objective limitation of the "natural" framework [Babaev, M. M. and Pudovochkin, Yu. E., 2016, p. 421]. Nevertheless, the criminal law is necessary, in the hands of the state, to act as the most repressive tool used in dealing with socially dangerous conflicts in cases where the use of means of other branches of law is considered inappropriate, ineffective, and/or inadequate. Criminal legislation is a means of criminal law policy, the priorities of which, according to A. I. Raroga, "must have sufficient social and legal grounds, and the criminal law means of ensuring these priorities must be, firstly, adequate to the protected social values, and secondly, practically realizable, that is, meet the needs of practice and serve as a convenient tool for influencing socially unacceptable criminal law phenomena" [Rarog, A. I., 2015, p. 13].

We believe that the regulation of non-criminal criminal offenses is a socially significant area of criminal law policy that helps to resolve or reduce the painful difficulties of problems that arise in the process of lawmaking and law enforcement.

\section{Theoretical Basis. Methods}

The object of the research is the criminal law policy and the reform of criminal law in terms of the regulation of non-criminal criminal acts. The theoretical basis of the work was domestic doctrinal sources involving three topics. Firstly, modern concepts of criminal policy. Secondly, social consequences of mitigation or toughening of criminal repression. Thirdly, forms and means of implementation of criminal law policy.

In carrying out a systemic, logical and legal analysis of the Russian criminal legislation, the following six grounds were considered. Firstly, the problems of law-making activities in establishing the boundaries of criminalisation. Secondly, the problem of preserving human resources during the implementation of a repressive criminal law policy. Thirdly, the problem of preserving the economic resource because of criminal law policy. Fourthly, problems of ensuring the principle of inevitability of criminal liability. Fifthly, the possibility of resolving a criminal offense conflict in an alternative way, and finally and sixthly, the possibility of self-defense of individual rights by means of criminal law.

\section{Results}

As a result of the study, it was concluded that the social significance of the regulation of non-criminal criminal acts is determined by the ability to solve the problems arising in the process of implementing criminal law policy.

The problem of lawmaking lies in the establishment of the boundaries of criminalisation. In modern Russia, the facts of excessive, unjustified criminalisation, miscalculations on the part of the legislator in recognising acts as socially dangerous (and accordingly criminal), are already recorded [Korobeyev, A. I., 2012, pp. 112-113; Burlakov, V. N., 2015, p. 35; Gilinsky, Ya. I., 2015, p. 40; Babaev, M. M. and Pudovochkin, Yu. E., 2016, pp. 425-426; Ivanov, N. G., 
2017, p. 78; Gladkikh, V. I., 2018]. In this case, the use of repression in the form of criminal punishment to unjustifiably criminalise acts can generate new legal and social conflicts [Tolpykin, V. E., 2009]. N. I. Pikurov explains: "Strengthening criminal law repression in itself is not only incapable of resolving the conflict, but can also cause greater tension, which often leads to negative consequences for the existing legal order... The criminal law remains only an auxiliary, and not the most successful, tool for resolving social -economic conflicts... The excessive use of criminal repression to prevent social conflicts in the absence of measures aimed at eliminating the socio-economic and political causes of such conflicts, can only provoke their further aggravation" [Pikurov, N. I., 2012]. M. M. Babaev and Yu. E. Pudovochkin also explain that "the absence or inability to find effective solutions to social problems, together with an attempt to solve them by means of criminal law not adapted for this, contributes to the growth of social discontent and tension, its accumulation" [Babaev, M. M. and Pudovochkin, Yu. E., 2020, p. 93].

In such a situation, the intensity of the conflict can be reduced at the level of law enforcement by the following means. Firstly, through the use of the normative construction of the act, formally containing signs of a certain corpus delicti, but due to its insignificance, it does not pose a public danger. The social conflict resulting from the erroneous establishment of the boundaries of criminalisation is resolved at the law enforcement level, when the law enforcement officer, having established in the assessed actions (i. e. inaction) of a person, signs of a certain corpus delicti, nevertheless comes to the conclusion that the act is insignificant and terminates the criminal case. Secondly, through the implementation of the constructions of positive post-criminal acts regulated in the criminal law, affecting the release of a person from criminal liability, punishment, and mitigation.

According to the opinion of A. M. Balafendiev, exemption from criminal liability is intended to eliminate internal contradictions inherent in criminal law [Balafendiev, A. M., 2010, p. 9]. The institution of exemption from criminal liability gives the method of criminalising socially dangerous acts the necessary flexibility. This translates the state's reaction in the presence of the conditions provided for in the law into a positive channel and thereby eliminates the negative social costs of punitive influence on persons who have committed minor crimes, persons who have shown active remorse and abstained from committing new crimes [Sverchkov, V. V., 2008; Korobeyev, A. I., 2019, pp. 40-41].

The inability of the state to adequately assess the real social danger of a criminalised act is the condition for the inevitable emergence of a social conflict. The regulation in the criminal law of an insignificant act or positive anti-criminal behavior helps to reduce the escalation of the negative consequences of the designated conflict through two main forms. Firstly, narrowing the boundaries of the criminal (for example, at the law enforcement level - when an illegal criminal act is recognised as insignificant). Secondly, a decrease in the fear of criminal law (for example, through the widespread 
practice of exempting a person from criminal liability in the presence of appropriate positive post-criminal behavior).

The regulation of non-criminal acts in this case is a kind of "safety mechanism" of criminal law policy, a means of protection against excessive criminalisation. That is, it is a way to ensure compliance of legislative formulas with the realities of life and strike a balance between lawmaking and law enforcement.

The problem of preserving human resources. Repressive criminal policy deprives society of a social resource on a larger scale than it happens when the repressive beginning of criminal policy is expressed minimally [Babaev, M. M. and Pudovochkin, Yu. E., 2020, p. 72]. The most important value in a democratic rule-of-law state - human resources - suffers from the most pronounced repressive criminal policy.

A. G. Khlebushkin explains that when a criminal prohibition is introduced, there are always at least three types of social costs. Firstly, limiting the rights and freedoms of citizens by expanding the range of prohibited acts. Secondly, an increase in the number of the convicted population. Thirdly, the growth of economic costs associated with the implementation of criminal proceedings and the execution of punishment according to the introduced norms of the criminal law [Khlebushkin, A. G., 2014, p. 49].

A. I. Korobeyev refers to five side effects of the criminal law prohibition. Firstly, "stigmatisation" of a certain part of the population, the receipt by citizens of the stigma "criminal". Secondly, the weakening of socially useful ties of convicts up to their complete loss. Thirdly, a decrease in the professional qualifications of convicts obtained before the commission of a crime. Fourthly, exclusion of a certain number of citizens from various spheres of socially useful activity. Fifthly, additional costs for the resocialisation and reintegration of convicts in the post-penitentiary period [Korobeyev, A. I., 2019, pp. 81-82].

In our opinion, factors contributing to minimising these consequences and preserving human resources include the regulation of positive post-criminal behavior affecting the release of a person from criminal liability (Articles 7576.2 of the Criminal Code of the Russian Federation). They also include the release of a person from criminal punishment (for example, voluntarily undergoing treatment for drug addiction, medical and social rehabilitation (Article 82.1 of the Criminal Code RF), and the appointment of a conditional sentence, as well as the use of parole from serving a sentence.

In the event that a person who has committed a crime will not be assigned long terms of imprisonment, the state will focus on punishments not related to imprisonment. It will apply other measures of a criminal-legal nature, other forms of implementation of criminal liability, which means the vector of criminal-law policy will focus on the preservation of human and human capital. Such a policy is capable of minimising the negative social consequences of serving long prison terms. These are namely:

Firstly, the likelihood of maintaining family, kinship, friendship, and relations will increase, which is not typical when serving long prison terms. 
Secondly, the problem of employment would be partially solved. If, during conviction, when applying other forms of implementation of criminal liability, the workplace is retained for the person, then the likelihood of compensation for the damage caused by the crime will be more real. In Russia, where there is a high level of unemployment, it is much more difficult for persons who have served a sentence of imprisonment with a criminal record to compete with those who are not characterised by this "social stigma". The regulation of other measures of a criminal-legal nature, for example the practice of applying the grounds for exemption from criminal liability can reduce the level of convictions not only among persons who have committed criminal acts, but also reduce the proportion of persons who have committed crimes in relation to the entire society.

Thirdly, one of the reasons for the existence of crime is its self-reproduction. Unfortunately, prison colonies sometimes do not correct the convicted person, nor do they educate one into a law-abiding citizen, but rather in fact act as a kind of "criminal school". This contributes to maintaining a high level of "criminal infection" of the population [Babaev, M. M. and Pudovochkin, Yu. E., 2020, p. 73]. The use of punishments not related to imprisonment, the use of other forms of implementation of criminal liability can protect a person who has committed a criminal act from turning him into a recidivist or a professional criminal.

Fourthly, the indicated policy will help to reduce the overcrowding of places of detention. This is one of the conditions that is also a factor in the regulation of positive penitentiary behavior, which affects the widespread use of the institution of parole.

Raising the question of the negative social consequences of the use of long terms of imprisonment, the author does not call on the legislator and law enforcement officer to completely abandon them, which is impossible, given the level of grave and especially grave crimes against the person, property, public safety, and public morality. In this case, we are talking about the fact that the punishment and other measures of a criminal-legal nature, imposed on the person who committed the crime, should first of all comply with the principle of justice. The state, when resolving the criminal conflict that has arisen, does not focus on the most repressive instruments of the criminal law.

The solution to this problem is to ensure the principle of differentiation and individualisation of criminal responsibility and punishment, which is possible only with a proper assessment of the post-criminal positive. Examples include positive steps, such as active repentance, reconciliation with the victim, compliance with the sentence serving regime) and negative measures - for example, evading the investigation or trial, violation of pre-trial agreements on cooperation, evasion of the convict from serving the sentence) the behavior of the individual.

The problem of preserving the economic resource is essential. Repressive criminal law policies require huge economic investments. When assessing its economic efficiency, calculated through the ratio of the results achieved and the corresponding financial costs, it will never be considered effective. Howe- 
ver, this fully applies to liberal criminal law policy. The main line concept of crime prevention in a legal and democratic social state should never depend on the solution of the issue, whether it is economically beneficial or not. However, the implementation of any preventive measure, the introduction of a new criminal prohibition, or the type of punishment will always depend on the availability of appropriate financial resources.

The regulation of the circumstances affecting the release of a person from criminal liability or punishment, (such as precluding the criminality of an act, an act of insignificance, or positive post-criminal acts) indicates that there are instruments in the criminal law policy implemented by the state which can be assessed as liberal and humane, intended to reduce criminal repression.

An inevitable consequence of the implementation of a designated criminal law policy should be a reduction in the number of people convicted to the actual terms of serving a sentence in the form of imprisonment. There should be a decrease in the number of employees working in places of detention, and, accordingly, a decrease in the economic costs of the penal system for the maintenance of convicts in places of deprivation of liberty.

Nevertheless, science has proven that a liberal criminal policy, in comparison with a repressive one, is not less costly, more economically profitable, and perhaps, on the contrary, requires more funding for its effectiveness (for example, for preventive and social-rehabilitation aspects) [Babaev, M. M. and Pudovochkin, Yu. E., 2020, pp. 122-123].

At the same time, the state, through the regulation of positive post-criminal acts affecting the release of persons from criminal liability, is trying to use the appropriate instruments of the criminal law not only to preserve, but also to replenish its economic resource. For example, exemption from criminal liability in connection with the imposition of a court fine is gaining widespread practice. During the period of validity of Articles 762, 1044, and 1055 of the Criminal Code of the Russian Federation, the application of a judicial fine has confirmed its relevance in law enforcement practice. In accordance with the statistical data of the Judicial Department at the Supreme Court of the Russian Federation, a court fine in 2017 was assigned to 20639 persons, in 2018 - 33329 persons, and in 2019 - 52461 persons $^{1}$.

Researchers of criminal policy have already established the fact that one of the goals of the ongoing reform of domestic criminal law is to replenish state revenues in order to financially support its activities [Tarasov, A. A., et al., 2017, pp. 59-90]. One of the means of this criminal law policy is the

Review of judicial practice of exemption from criminal liability with the appointment of a court fine (Article 762 of the Criminal Code of the Russian Federation) (Approved by the Presidium of the Supreme Court of the Russian Federation on July 10, 2019). URL: https://www.vsrf.ru/documents/thematics/28088/; Judicial statistics of the Judicial Department under the Supreme Court of the Russian Federation. URL: http: / / cdep.ru/index.php?id=79\&item=5259 
regulation of positive post-criminal acts in the form of payment of a sum of money to the state (for example, compensation for damage, forfeit, transfer to the federal budget of monetary compensation in the amount of double the amount of damage caused or double the amount of income obtained as a result of the commission of a crime, etc.).

The problem of ensuring the principle of inevitability of criminal liability is crucial. It would be wrong to admit that the principle of inevitability of criminal liability is realised only when each person who committed a crime has experienced the most repressive means of criminal law, namely punishment. The implementation of the principle of the inevitability of criminal liability also occurs in those cases when in relation to each person who violated the criminal prohibition, there is a response and based on the law of the state reaction in the form of the use of variable criminal law mechanisms, characterised by varying degrees of criminal repression [Aryamov, A. A. and Kolyvantseva, M. A., 2017, pp. 39-43]. So, A. I. Korobeyev explains that "this principle includes the need to: identify all, without exception, crimes committed in reality; bringing to criminal responsibility all persons guilty of committing crimes; the application to each of them of measures of criminal punishment, or measures replacing it, or, finally, release from criminal liability and (or) from punishment in cases and on the grounds provided for by the criminal law; compensation for the harm caused by the crime there, of course, where possible" [Korobeyev, A. I., 2019, pp. 38-39].

The necessary conditions for the response of the state to the fact of committing a crime should be, at a minimum, its identification, registration, disclosure, bringing a person to criminal responsibility. Considering the statistics of annually registered crimes, their detection rate, the number of persons brought to criminal responsibility, we see:

Table 1 / Таблиuа 1

\begin{tabular}{|c|c|c|c|}
\hline Year & $\begin{array}{c}\text { Number of registered crimes } \\
\text { (thousand) / Количество } \\
\text { зарегистрированных } \\
\text { преступлений (тыс.) }\end{array}$ & $\begin{array}{c}\text { Number of identified persons who } \\
\text { have committed crimes (thousand) } \\
\text { / Количество выявленных лиц, } \\
\text { совершивших преступления (тыс.) }\end{array}$ & $\begin{array}{c}\text { Number of unsolved crimes } \\
\text { (thousand) / Количество } \\
\text { не раскрытых преступлений } \\
\text { (тыс.) }\end{array}$ \\
\hline 2007 & 3582,5 & 1317,6 & 1863,9 \\
\hline 2008 & 3209,9 & 1256,2 & 1479,5 \\
\hline 2009 & 2994,8 & 1219,8 & 1309,1 \\
\hline 2010 & 2628,8 & 1111,1 & 1193,3 \\
\hline 2011 & 2404,8 & 1041,3 & 1980,1 \\
\hline 2012 & 2302,2 & 1010,9 & 1014,7 \\
\hline 2013 & 2206,2 & 1012,6 & 950,3 \\
\hline 2014 & 2166,4 & 1000,1 & 948,6 \\
\hline 2015 & 2351,2 & 1063,03 & 1026,2 \\
\hline
\end{tabular}




\begin{tabular}{|c|c|c|c|}
\hline Year & $\begin{array}{c}\text { Number of registered crimes } \\
\text { (thousand) / Количество } \\
\text { зарегистрированных } \\
\text { преступлений (тыс.) }\end{array}$ & $\begin{array}{c}\text { Number of identified persons who } \\
\text { have committed crimes (thousand) } \\
\text { / Количество выявленных лиц, } \\
\text { совершивших преступления (тыс.) }\end{array}$ & $\begin{array}{c}\text { Number of unsolved crimes } \\
\text { (thousand) / Количество } \\
\text { не раскрытых преступлений } \\
\text { (тыс.) }\end{array}$ \\
\hline 2016 & 2160,0 & 1015,8 & 983,3 \\
\hline 2017 & 2058,5 & 967,1 & 886,7 \\
\hline 2018 & 1991,5 & 931,1 & 860,4 \\
\hline 2019 & 2024,3 & 884,7 & $915,2^{2}$ \\
\hline
\end{tabular}

From the data presented, it is easy to conclude that every year there is a significant number of unsolved crimes, and we are talking only about acts that have been registered. Without reasoning about the problems of objectivity of Russian statistics, about the real reflection of existing crime in it, we will only note that according to various criminological studies, the level of latent crime is quite high, and the number of crimes actually committed annually can be expressed in a figure from 12 to 30 million [Luneev, V. V., 2015, p. 87].

In this situation, it is necessary to remember that the existing system of justice in the state with the means and staff at its disposal is incapable of "digesting" not only the entire volume of crime, but even its officially recorded (registered) part [Gilinsky, Ya. I. , 2009, p. 55].

In such an environment, the regulation of positive post-criminal acts aimed at facilitating and solving crimes (for example, active repentance, pre-trial cooperation agreement, etc.) will undoubtedly contribute, at least to a small extent, to the implementation of the principle of inevitability of criminal liability. Striving to ensure the principle of the inevitability of criminal liability is a prerequisite for public respect for the current criminal legislation.

The regulation of positive post-criminal acts is a tool for solving a criminallegal conflict in an alternative way. The question of using alternative methods of resolving a criminal-legal conflict is relevant for Russian criminal law. A condition for resolving a criminal-legal conflict in an alternative way is a dialogue between a criminal and a victim, a search for a compromise between them, aimed at exhausting the arisen socio-legal conflict.

By regulating mediation methods of resolving criminal-legal conflicts such vectors of criminal law policy as the economy of criminal law repression, its reduction, restorative justice (restorative justice), humanisation, and liberalisation are implemented [Aryamov, A. A. and Kolyvantseva, M. A., 2017, p. 41; Matveeva, Ya. M., 2017, p. 140; Lapshin, V. F., 2012, p. 133]. The most notable examples are

- active repentance (Article 75 of the Criminal Code of the Russian Federation),

2 Official website of the Ministry of Internal Affairs of the Russian Federation // https: / /mvd.rf/reports / 1/ 
- reconciliation with the victim (Article 76 of the Criminal Code of the Russian Federation),

- compensation for damage (Article 76.1 of the Criminal Code of the Russian Federation),

- payment of a court fine (Article 76.2 of the Criminal Code of the Russian Federation),

- voluntary release of a kidnapped person (Article 126 of the Criminal Code of the Russian Federation),

- release of a hostage (Article 206 of the Criminal Code of the Russian Federation),

- voluntary surrender of weapons, explosive devices, explosives (Articles 222-223.1 of the Criminal Code of the Russian Federation), and

- voluntary surrender of drugs (Article 228 of the Criminal Code of the Russian Federation).

Legislative consolidation of non-criminal criminal acts can dilute the onesidedness of the criminal law in resolving the social and legal conflict resulting from criminal behavior. The doctrine of criminal law justifiably raises the problem of the impotence of the criminal law, when there is its inadequacy to the specific conditions of the place and time of its application, or inadequate use of the force of repression and (or) insufficient flexibility in the approach to the practice of applying measures of more humane content [Babaev, M. M. and Pudovochkin, Yu. E., 2016, p. 421].

The indicated flexibility in the practice of applying measures of a more humane content is precisely capable of providing other already regulated measures of a criminal-legal nature, other forms of implementation of criminal liability. The basis of this is the corresponding non-criminal criminal-legal acts (for example, exemption from criminal liability in connection with an active repentance, reconciliation with the victim; non-prosecution in case of voluntary release of the abducted person; release from criminal liability in case of voluntary surrender of narcotic drugs, psychotropic substances, weapons; parole from serving a sentence in the presence of appropriate positive penitentiary behavior, etc.).

The problem of protecting individual rights by means of criminal law is worth considering. One of the tasks of the criminal law is to protect human and civil rights and freedoms from criminal encroachments (part 1 of article 2 of the Criminal Code of the Russian Federation). In our opinion, it is more accurate and more correct to talk about protection from socially dangerous encroachments, both criminal and non-criminal [Lobanova, L. V., 2012, p. 146]. A. V. Denisova explains that "ensuring the safe existence of people in society is a continuously realised goal of criminal law as an industry performing the main burden of countering socially dangerous acts" [Denisova, A. V., 2018, p. 67]. Nevertheless, the presence of the principle of humanism in the criminal law did not become a guarantee of ensuring human security. Public order, public safety, the safety of a particular person, are often provided by measures that are far from being 
based on the norms of criminal law. For example, preventive measures used by law enforcement agencies, something the legislator himself is well aware of.

Therefore, by regulating the circumstances precluding the criminality of an act, a person is given the opportunity:

1) in conditions of necessary defense to protect himself or other persons from socially dangerous encroachments;

2) to detain a person who has committed a crime for delivery to the authorities or in order to prevent him from committing other criminal acts;

3) cause harm to social relations protected by criminal law in conditions of extreme necessity, physical or mental coercion;

4) take risks to achieve a socially useful goal, and;

5) be an undisciplined subordinate when executing an order or instruction in cases of realizing their illegal nature. V. I. Mikhailov [2012, pp. 179-180] explains that situations, the resolution of which is associated with the infliction of legitimate harm, arise when solving socially significant problems in various areas of positive social activity.

The regulation of the circumstances precluding the crime of acts, which gives the individual the opportunity to be socially active, expands the boundaries of his rights and freedoms, promotes moral and physical development while self-protecting his rights by means of criminal law.

In the science of criminal law, the question is consistently raised that the positive development of society can be ensured by legislative consolidation of other circumstances that exclude the criminality of an act. Notable examples include euthanasia, causing harm while playing sports, organ transplantation, consent of a person, compliance with legislation, conducting operational-search measures, exercise of their rights, and performance of professional duties [Kozlov, A. P., 2012, p. 104; Nikulenko, A. V., 2012, pp. 187-189; Oreshkina, T. Yu., 2012, pp. 202-203].

\section{Discussion and Conclusion}

The regulation of non-criminal criminal offenses is a kind of "safety mechanism" of criminal law policy, a means of protection against excessive criminalisation, a way to ensure compliance of legislative formulas with life realities and a balance between lawmaking and law enforcement.

The consolidation of positive post-criminal behavior in the criminal law that affects the release of a person from criminal liability, the release of a person from criminal punishment, the appointment of a suspended sentence, the use of parole from serving a sentence, contribute to the preservation of human resources.

The establishment of positive post-criminal acts in the form of payment of a sum of money to the state is one of the means of replenishing the state's income in order to financially support its activities.

Regulated other measures of a criminal-legal nature, other forms of implementation of criminal liability, the basis for the application of which 
were the relevant non-criminal criminal-legal acts, provide the flexibility of law enforcement practice when resolving a criminal conflict in an alternative way.

Legislative consolidation of circumstances precluding criminality of acts, which gives the individual the opportunity to be socially active, expands the boundaries of his rights and freedoms, contributes to his moral, physical development with self-defense of his rights by means of criminal law.

\section{References}

Aryamov, A. A. and Kolyvantseva, M. A., 2017. Alternativnyye formy resheniya ugolovno-pravovogo konflikta $=$ [Alternative forms of solving the criminal-legal conflict]. Monograph. Moscow: Jurlitinform. (In Russ.) Babaev, M. M. and Pudovochkin, Yu. E., 2015. [Criminal punishment in a conflictological context]. Vestnik yuridicheskogo fakulteta Yuzhnogo federalnogo universiteta $=$ Bulletin of the Faculty of Law of the Southern Federal University, 1(3), pp. 15-26. (In Russ.)

Babaev, M. M. and Pudovochkin, Yu. E., 2016. [Repressive solution of social problems: causes and consequences]. Vserossiyskiy kriminologicheskiy zhurnal $=$ All-Russian Criminological Journal, 10(3), pp. 419-430. (In Russ.)

Babaev, M. M. and Pudovochkin, Yu. E., 2020. Rossiyskaya ugolovnaya politika XXI veka $=$ [Russian criminal policy of the XXI century]. Monograph. Moscow: Jurlitinform. (In Russ.)

Balafendiev, A. M., 2010. Osvobozhdenie ot ugolounoj otvetstvennosti v svyazi s pozitivnym postkriminal'nym povedeniem: social'no-pravovye predposylki, sushchnost' $i$ sistematizaciya vidov $=$ [Exemption from criminal liability in connection with positive post-criminal behavior: social and legal prerequisites, essence and systematization of types]. Abstract of Cand. Sci. (Law) Dissertation. Kazan. (In Russ.)

Burlakov, V. N., 2015. [Modernization of the criminal law and its results]. Ugolounoye pravo: strategiya razvitiya $v$ XXI veke $=[$ Criminal law: development strategy in the XXI century]. Materials of the XII International scientific and practical conference. Moscow, Russian Federation, 29-30 January 2015. Moscow: RG-Press. Pp. 34-37. (In Russ.)

Denisova, A. V., 2018. [Ensuring the safe coexistence of people in society as the main goal of Russian criminal law]. Obespecheniye natsionalnoy bezopasnosti - prioritetnoye napravleniye ugolounopravovoy. kriminologicheskoy $i$ ugolovno-ispolnitelnoy politiki $=[$ Ensuring national security-a priority direction of criminal law, criminology and 
criminal enforcement policy]. Materials of the XI Russian Congress of criminal law dedicated to the memory of doctor of law, Professor Vladimir Sergeevich Komissarov. Moscow, Russian Federation, 31 May - 1 June 2018. Moscow: Yurlitinform. Pp. 65-68. (In Russ.)

Gilinsky, Ya. I., 2009. Kriminologiya: teoriya, istoriya, empiricheskaya baza, sotsialnyy kontrol = [Criminology: theory, history, empirical base, social control]. St. Petersburg: Publishing house of R. Aslanov "Yuridicheskij centr Press". (In Russ.)

Gilinsky, Ya. I., 2015. Criminal legislation in modern Russia: critical notes. Ugolounoye pravo: strategiya razvitiya $v$ XXI veke $=[$ Criminal law: development strategy in the XXI century]. Materials of the XII International scientific and practical conference. Moscow, Russian Federation, 29-30 January 2015. Moscow: RG-Press. Pp. 38-41. (In Russ.)

Gladkikh, V. I., 2018. [System problems of the Russian criminal policy]. Obespecheniye natsionalnoy bezopasnosti - prioritetnoye napravleniye ugolovno-pravovoy, kriminologicheskoy $i$ ugolovno-ispolnitelnoy politiki $=[$ Ensuring national security-a priority direction of criminal law, criminology and criminal enforcement policy]. Materials of the XI Russian Congress of criminal law dedicated to the memory of doctor of law, Professor Vladimir Sergeevich Komissarov. Moscow, Russian Federation, 31 May - 1 June 2018. Moscow: Yurlitinform. Pp. 58-61. (In Russ.)

Ivanov, N. G., 2017. [Quality of the criminal law and social significant value that needs criminalization]. Ugolounoye pravo: strategiya razvitiya $v X X I$ veke $=[$ Criminal law: development strategy in the XXI century: proceedings of the XIV]. International scientific and practical conference. Moscow, Russian Federation, 26-27 January 2017. Moscow: OriginalMaket. Pp. 77-80. (In Russ.)

Karpets, I. I., 1973. Nakazaniye: Sotsialnyye, pravovyye $i$ kriminologicheskiye problemy = [Punishment: Social, legal and criminological problems]. Moscow: Legal Literature. (In Russ.)

Khlebushkin, A. G., 2014. [The Social contract and the legitimacy of criminal and legal impact]. Ugolounoye pravo: strategiya razvitiya $v$ XXI veke $=$ [Criminal law: development strategy in the XXI century]. Materials of the XI International scientific and practical conference. Moscow, Russian Federation, 30-31 January 2014. Moscow: Prospect. Pp. 47-51. (In Russ.)

Korobeev, A. I., 2012. [Criminal law policy of Russia: from dawn to stagnation]. Souremennaya ugolounaya politika: poisk optimalnoy modeli= [Modern criminal policy: search for the optimal model]. Materials of the VII Russian Congress of criminal law. Moscow, Russian Federation, 31 May - 1 June 2012. Moscow: Prospekt. Pp. 112-115. (In Russ.) 
Korobeev, A. I., 2019. Ugolovno-pravovaya politika Rossii: ot genezisa do krizisa $=$ [Criminal law policy of Russia: from the genesis of the crisis]. Monograph. Moscow: Jurlitinform. (In Russ.)

Kozlov, A. P., 2012. [Criminal policy: its some criminal miscalculations in relation to the current Criminal Code]. Sovremennaya ugolovnaya politika: poisk optimalnoy modeli $=[$ Modern criminal policy: search for the optimal model]. Materials of the VII Russian Congress of criminal law. Moscow, Russian Federation, 31 May - 1 June 2012. Moscow: Prospekt. Pp. 99-108. (In Russ.)

Lapshin, V. F., 2012. [Legal analysis of exemption from criminal liability in cases of crimes in the sphere of economic activity]. Sovremennaya ugolounaya politika: poisk optimalnoy modeli = [Modern criminal policy: search for the optimal model]. Materials of the VII Russian Congress of criminal law. Moscow, Russian Federation, 31 May - 1 June 2012. Moscow: Prospekt. Pp. 133-136. (In Russ.)

Lobanova, L. V., 2012. [On some novelties of criminal legislation and the balance of forms and methods of criminal law policy]. Sovremennaya ugolounaya politika: poisk optimalnoy modeli = [Modern criminal policy: search for the optimal model]. Materials of the VII Russian Congress of criminal law. Moscow, Russian Federation, 31 May - 1 June 2012. Moscow: Prospekt. Pp. 145-150. (In Russ.)

Luneev, V. V., 2015. Epokha globalizatsii $i$ prestupnost $=[$ The era of globalization and crime]. Moscow: Infra-M. (In Russ.)

Matveeva, Ya. M., 2017. [Alternative ways of solving the criminal law conflict in the criminal law of Russia: modernity and prospects]. Ugolounoye pravo: strategiya razvitiya $v$ XXI veke $=[$ Criminal law: development strategy in the XXI century: proceedings of the XIV]. Materials of the XIV International scientific and practical conference. Moscow, Russian Federation, 26-27 January 2017. Moscow: OriginalMaket. Pp. 139-142. (In Russ.)

Mikhailov, V. I., 2012. Purpose of the criminal law and the theory of lawful harm. Sovremennaya ugolounaya politika: poisk optimalnoy modeli $=[$ Modern criminal policy: search for the optimal model $]$. Materials of the VII Russian Congress of criminal law. Moscow, Russian Federation, 31 May - 1 June 2012. Moscow: Prospekt. Pp. 177-185. (In Russ.)

Nikulenko, A. V., 2012. [Prospects of criminal policy in the sphere of legislative consolidation of new circumstances regulating lawful infliction of harm]. Sovremennaya ugolounaya politika: poisk optimalnoy modeli $=[$ Modern criminal policy: search for the optimal model $]$. Materials of the VII Russian Congress of criminal law. Moscow, Russian Federation, 31 May - 1 June 2012. Moscow: Prospekt. Pp. 186-191. (In Russ.)

Oreshkina, T. Yu., 2012. The system of notes to articles of the Special part of the criminal code of the Russian Federation needs to be 
improved. Sovremennaya ugolovnaya politika: poisk optimalnoy modeli $=[$ Modern criminal policy: search for the optimal model $]$. Materials of the VII Russian Congress of criminal law. Moscow, Russian Federation, 31 May - 1 June 2012. Moscow: Prospekt. Pp. 200-207. (In Russ.)

Pikurov, N. I., 2012. Limited opportunities of the criminal law in preventing social conflicts in the context of reforming socio-economic relations. Sovremennaya ugolovnaya politika: poisk optimalnoy modeli $=[$ Modern criminal policy: search for the optimal model $]$. Materials of the VII Russian Congress of criminal law. Moscow, Russian Federation, 31 May - 1 June 2012. Moscow: Prospekt. Pp. 220-221. (In Russ.)

Rarog, A. I., 2015. Priorities of the Russian criminal law policy. Ugolovnoye pravo: strategiya razvitiya $v$ XXI veke $=$ [Criminal law: development strategy in the XXI century]. Materials of the XII International scientific and practical conference. Moscow, Russian Federation, 29-30 January 2015. Moscow: RG-Press. Pp. 13-17. (In Russ.)

Sverchkov, V. V., 2008. Konceptual'nye osnovy resheniya problem osvobozhdeniya ot ugolovnoj otvetstvennosti $=$ [Conceptual foundations for solving the problems of exemption from criminal liability]. Abstract of Dr. Sci. (Law) Dissertation. Nizhny Novgorod. (In Russ.)

Tarasov, A. A., Sharipov, A. R., Kostrova, M. B., et al., 2017. Realizatsiya ugolounoy politiki: souremennyye problemy ugolovnogo $i$ ugolounoprotsessualnogo pravotvorchestva, primeneniya $i$ kadrovogo obespecheniya $=[$ Implementation of criminal policy: modern problems of criminal and criminal-procedural law-making, application and personnel support]. Ed. A. A. Tarasov. Moscow: Justice. (In Russ.)

Tolpykin, V. Ye., 2009. [Nasiliye i nenasiliye kak formy proyavleniya i razresheniya sotsial'nykh protivorechiy i konfliktov]. Filosofiya prava $=$ [Philosophy of Law], 6, pp. 7-11. (In Russ.)

\section{Список испомьзованной митературы}

Арямов А. А., Колыванцева М. А. Альтернативные формы решения уголовно-правового конфцикта : моногр. М. : Юрлитинформ, 2017. 192 c.

Бабаев М. М., Пудовочкин Ю. Е. Репрессивное решение социальных проблем: причины и последствия // Всероссийский криминологический журнал. 2016. Т. 10, № 3. С. 419-430.

Бабаев М. М., Пудовочкин, Ю. Е. Российская уголовная политика XXI века : моногр. М. : Юрлитинформ, 2020. 208 с.

Бабаев М. М., Пудовочкин Ю. Е. Уголовное наказание в конфликтоцогическом контексте / / Вестник юридического факультета Южного федерального университета. 2015. № 1 (3). С. 15-26. 
Балафендиев А. М. Освобождение от уголовной ответственности в связи с позитивным посткриминальным поведением: социальноправовые предпосылки, сущность и систематизация видов : автореф. дис. ... канд. юрид. наук. Казань, 2010. 27 с.

Бурлаков В. Н. Модернизация уголовного закона и ее результаты // Уголовное право: стратегия развития в XXI веке : материамы XII Междунар. науч.-практ. конф. (29-30 янв. 2015 г.). М. : РГПресс, 2015. С. 34-37.

Гилинский Я. И. Криминология: теория, история, эмпирическая база, социальный контроль. СПб. : Изд-во Р. Асланова "Юридический центр Пресс", 2009. 504 с.

Гилинский Я. И. Уголовное законодатецьство в современной России: критические заметки // Уголовное право: стратегия развития в XXI веке : материалы XII Междунар. науч.-практ. конф. (29-30 янв. 2015 г.). М. : РГ-Пресс, 2015. С. 38-41.

Гладких В. И. Системные проблемы российской уголовной политики // Обеспечение национальной безопасности - приоритетное направление уголовно-правовой, криминологической и уголовноисполнительной политики : материалы XI Рос. конгр. угол. права, посвящ. памяти д-ра юрид. наук, проф. Владимира Сергеевича Комиссарова, состоявшегося 31 мая - 1 июня 2018 г. М. : Юрлитинформ, 2018. С. 58-61.

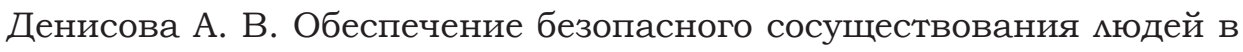
обществе как главная цель российского уголовного права // Обеспечение национальной безопасности - приоритетное направление уголовно-правовой, криминологической и уголовно-исполнительной политики : материалы XI Рос. конгр. угол. права, посвящ. памяти д-ра юрид. наук, проф. ВАадимира Сергеевича Комиссарова, состоявшегося 31 мая - 1 июня 2018 г. М. : Юрлитинформ, 2018. С. 6568.

Иванов Н. Г. Качество уголовного закона и социальная значимая ценность, нуждающаяся в криминализации // Уголовное право: стратегия развития в XXI веке : материалы XIV Междунар. науч.-практ. конф. (26-27 янв. 2017 г.). М. : Оригинал-Макет, 2017. С. 77-80.

Карпец И. И. Наказание: Социальные, правовые и криминологические проблемы. М. : Юрид. цит., 1973. 287 с.

Козмов А. П. Уголовная политика: ее некоторые уголовные просчеты применительно к действующему УК // Современная уголовная по-

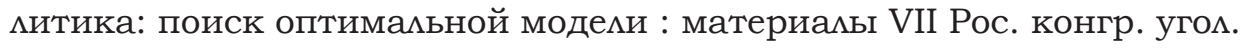
права (31 мая - 1 июня 2012 г.). М. : Проспект, 2012. С. 99-108.

Коробеев А. И. Уголовно-правовая политика России: от рассвета до застоя // Современная уголовная политика: поиск оптималь- 
ной модели : материалы VII Рос. конгр. угоц. права (31 мая - 1 июня 2012 г.). М. : Проспект, 2012. С. 112-115.

Коробеев А. И. Уголовно-правовая политика России: от генезиса от кризиса : моногр. М. : Юрлитинформ, 2019. 352 с.

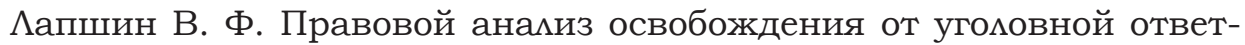
ственности по делам о преступлениях в сфере экономической деятельности // Современная уголовная политика: поиск оптимальной модеми : материалы VII Российского конгр. угол. права (31 мая 1 июня 2012 г.). М. : Проспект, 2012. С. 133-136.

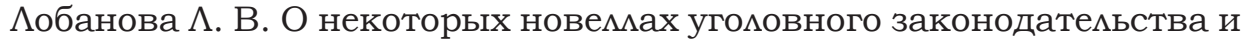
балансе форм и методов уголовно-правовой политики // Современная уголовная политика: поиск оптимальной модеми : материалы VII Рос. конгр. угоц. права (31 мая - 1 июня 2012 г.). М. : Проспект, 2012. C. $145-150$.

Аунеев В. В. Эпоха гмобализации и преступность. М. : Инфра-М, 2015. 272 c.

Матвеева Я. М. А^ьтернативные способы решения уголовно-правового конфцикта в уголовном праве России: современность и перспективы // Уголовное право: стратегия развития в XXI веке : материалы XIV Междунар. науч.-практ. конф. (26-27 янв. 2017 г.). М. : Оригинал-Макет, 2017. С. 139-142.

Михайлов В. И. Предназначение уголовного закона и теория правомерного вреда // Современная уголовная политика: поиск оптимальной модеми : материалы VII Рос. конгр. угол. права (31 мая 1 июня 2012 г.). М. : Проспект, 2012. С. 177-185.

Никуленко А. В. Перспективы уголовной политики в сфере законодательного закрепления новых обстоятельств, регламентирующих правомерное причинение вреда // Современная уголовная политика: поиск оптимальной модеми : материалы VII Рос. конгр. угол. права (31 мая - 1 июня 2012 г.). М. : Проспект, 2012. С. 186-191.

Орешкина Т. Ю. Система примечаний к статьям Особенной части УК РФ нуждается в совершенствовании // Современная уголовная политика: поиск оптимальной модели : материалы VII Рос. конгр. угол. права (31 мая - 1 июня 2012 г.). М. : Проспект, 2012. С. 200207.

Пикуров Н. И. Ограниченность возможностей уголовного закона в предупреждении социальных конфциктов в условиях реформирования социально-экономических отношений // Современная угомовная политика: поиск оптимальной модеми : материалы VII Рос. конгр. угоц. права (31 мая - 1 июня 2012 г.). М. : Проспект, 2012. C. 220-221. 
Рарог А. И. Приоритеты российской уголовно-правовой политики // Уголовное право: стратегия развития в XXI веке : материамы XII Междунар. науч.-практ. конф. (29-30 янв. 2015 г.). М. : РГПресс, 2015. С. 13-17.

Реализация уголовной политики: современные проблемы уголовного и уголовно-процессуального правотворчества, применения и кадрового обеспечения / А. А. Тарасов, А. Р. Шарипов, М. Б. Кострова и др. ; под общ. ред. А. А. Тарасова. М., 2017. 246 с.

Сверчков В. В. Концептуальные основы решения проблем освобождения от уголовной ответственности : автореф. дис. ... д-ра юрид. наук. Н. Новгород, 2008. 60 с.

Толпыкин В. Е. Насилие и ненасилие как формы проявления и разрешения социальных противоречий и конфмиктов // Философия права. 2009. № 6. С. 7-11.

Хлебушкин А. Г. Социальный контракт и мегитимность уголовноправового воздействия // Уголовное право: стратегия развития в XXI веке : материалы XI Междунар. науч.-практ. конф. (30-31 янв. 2014 г.). М. : Проспект, 2014. С. 47-51.

\section{Information about the author / Информация об авторе}

Denis A. Garbatovich, Cand. Sci. (Law), Associate Professor, Deputy Director for Research, Ural Branch, Russian State University of Justice (160 Pobedy Av., Chelyabinsk, 454135, Russian Federation)

Гарбатович Денис А^ександрович, кандидат юридических наук, доцент, заместитель директора по научной работе Уральского филиала Российского государственного университета правосудия (Российская Федерация, 454135, г. Челябинск, пр. Победы, д. 160).

E-mail: garbatovich@mail.ru

Submitted 28.09.2020; reviewed 30.10.2020; revised 02.02.2021.

Дата поступления рукописи в редакцию издания: 28.09.2020; дата одобрения после рецензирования: 30.10.2020; дата принятия статьи к опубмикованию: 02.02.2021. 


\title{
Способы защиты публично- правовых интересов в цивилистическом процессе
}

\author{
С. А. Бурмистрова \\ Уральский филиал ФГБОУВО «РОссийский государственный \\ университет правосудия», г. Челябинск, Российская Федерация \\ lelsi@yandex.ru
}

\begin{abstract}
Аннотация
Введение. В российском законодательстве и правовой науке нет общего перечня способов защиты публично-правовых субъективных прав и интересов. В итоге одни способы защиты применяются широко, другие имеют значительно меньшее применение, что ведет к слабой защищенности прав и интересов, которые могли бы получить защиту такими способами.

Теоретические основы. Методы. При проведении исследования автор опирался на следующие идеи:

- социальные интересы, регулируемые правом (правовые интересы), подразделяются на интересы с максимальной (субъективные права), минимальной (законные интересы) и промежуточной (законные интересы, которые актом правоприменения могут быть преобразованы в субъективные права) вероятностью достижения социального блага, на которое они направлены;

- правовые интересы в процессе реализации проходят ряд стадий, в каждой из которых они могут быть особым образом нарушены. Зная, что представляет собой нарушение в каждой из стадий, можно безошибочно выбрать меру или совокупность мер защиты способ защиты;

- значимость реализации правовых интересов для общества не одинакова. Общая (публичная) значимость ведет к тому, что интерес регулируется публичным правом. Частная значимость интереса влечет регулирование его частным правом.

Результаты исследования. Обосновано, что отношения, возникающие по поводу реализации публично-правовых интересов, могут базироваться на подчинении или равенстве, в связи с чем субъекты публично-правовых отношений могут обладать властным, подвластным и равным статусом.

Представлена система мер и мероприятий, которые следует применять при нарушениях публично-правовых интересов властных, подвластных и равных участников публичноправовых отношений на различных этапах реализации таких интересов.

Обсуждение и заключение. Полученные результаты способны послужить основой для совершенствования процессуальных средств защиты и производств по защите публичноправовых интересов.
\end{abstract}

Ключевые слова: обладатели публично-правовых интересов, реализация публично-правовых интересов, публично-правовая деятельность, действия по защите, меры и мероприятия по защите публично-правовых интересов, способы защиты

Для цитирования: Бурмистрова С. А. Способы защиты публично-правовых интересов в цивилистическом процессе // Правосудие/Justice. 2021. Т. 3, № 1. С. 69-85. DOI: 10.37399/2686-9241.2021.1.69-85. 


\title{
The measures to protect public legal interests in the civil process
}

\section{Svetlana A. Burmistrova}

\author{
Ural Branch, Russian State University of Justice, Chelyabinsk, \\ Russian Federation \\ For correspondence: lelsi@yandex.ru
}

\begin{abstract}
Introduction. The civil legislation of Russia has a list of general ways to protect civil rights. There is comprehensive list of ways to protect public-law subjective rights and interests either in legislation or in legal science. As a result, some methods of protection that are explicitly named in the law are widely used in practice and have been sufficiently studied in science, while others that do not have direct legislative support are little or practically not used in practice, which leads to weak protection of rights and interests that could be protected by such methods.

Theoretical Basis. Methods. In order to make the most complete list of the methods of protecting public-law subjective rights and interests and, if possible, bring such methods into the system, the author of the article proceeded from the following ideas:

- social interests regulated by law (legal interests) have a different probability of achieving the object (the social good they are aimed at) and are divided into three categories, namely interests with a maximum (subjective rights), minimum (legitimate interests) and intermediate probability of achieving the object (legitimate interests that can be transformed into subjective rights by an act of law enforcement);

- legal interests in the implementation process go through a number of stages, each of which can be violated in a special way. Knowing what constitutes a violation in each of the stages, allows an accurate choice of a method of protection from the range of availale measures;

- the importance of implementing legal interests for the society is not the same. General (public) significance leads to the fact that the interest is regulated by public law. The private significance of an interest entails its regulation by private law.

Results. It is argued that public and private entities can be carriers of public legal interests.

It is proved that relations arising from the implementation of public-legal interests can be based on subordination or equality, and therefore the subjects of public-legal relations can have a powerful, subordinate and equal status.

The article presents a system of measures and measures that should be applied in cases of violations of public-legal interests of powerful, subordinate and equal participants in public-legal relations at various stages of the implementation of such interests.

Discussion and Conclusion. The results obtained can serve as a basis for improving the procedural means of protection and proceedings for the protection of public legal interests.
\end{abstract}

Keywords: holders of public-legal interests, implementation of public-legal interests, public-legal activities, actions to protect, measures to protect public-legal interests, methods of protection

For citation: Burmistrova, S. A., 2021. The measures to protect public legal interests in the civil process. Pravosudie/Justice, 3(1), pp. 69-85. DOI: 10.37399/2686-9241.2021.1.69-85.

\section{Введение}

В российском праве нет такого суммарного перечня общих способов защиты публично-правовых прав и интересов, какой имеют гражданские права и который содержится в ст. 12 Гражданского кодекса Российской Федерации (части первой) от 30 ноября 1994 г. № 51-ФЗ (ред. от 
31.07.2020) ${ }^{1}$. В результате отдемьные, поименованные в цивицистическом процессуальном законодательстве способы защиты публичных прав и интересов, такие как оспаривание нормативных правовых актов и актов, обладающих нормативными свойствами [Никитин, С. В., 2010], оспаривание актов, решений, действий (бездействия) представителей вцасти [Хахалева, Е. В., 2011; Гатин, А. А., 2011], глубоко доктринально проработаны и широко применяются в судебной практике. Другие же, непоименованные способы защиты публично-правовых субъективных прав и законных интересов остаются малоисследованными и, как следствие, мало применяются судами, что ведет к слабой защищенности этих прав и интересов, которые могли бы получить защиту такими способами.

Обозначенная научная проблема, по нашему мнению, является следствием другой, более глобальной - проблемы неопределенности критерия разграничения права на публичное и частное, которую в настоящее время нельзя считать окончательно решенной. Данная проблема не позвомяет увидеть полную картину публично-правовых прав и интересов, понять, какими способами (путями) такие права и интересы могут оказаться нарушенными. Это, в свою очередь, не позволяет исследовать пути противодействия таким нарушениям, т. е. способы защиты и соответствующие таким способам защитные действия и их совокупность (меры и мероприятия).

В итоге часть пубцично-правовых прав и интересов получает защиту посредством производства, дмя этого не предназначенного (гражданского), несовершенными явцяются система процессуальных средств (инструментов) защиты таких прав и интересов, система основных производств, направ енных на защиту публично-правовых прав и интересов в административном судопроизводстве и производстве по демам, возникающим из административных и иных публичных правоотношений, арбитражного процесса.

\section{Теоретические основы. Методы}

Объектом исследования являются общественные отношения, складывающиеся в процессе выбора меры или совокупности мер (иными словами способа) защиты публично-правовых интересов.

Исследование основано на идее, впервые выдвинутой Р. Иерингом, о том, что право регулирует деятельность участников общественных отношений по реализации их интересов [Иеринг, Р., 1991, с. 3, 5 и др.; Иеринг, Р., 1881, с. 315 и др.]. В связи с тем, что поведение по реализации интересов явцяется предметом правового регулирования, такие интересы в более ранних работах автора настоящей статьи предложено именовать правовыми [Бурмистрова, С. А., 2020, с. 20 и след.].

1 Собрание законодательства Российской Федерации. 1994. № 32. Ст. 3301. 
Все правовые интересы явцяются объектами правовой охраны и защиты, но они различаются таким качеством, как вероятность достижения объекта (социального блага), на который такие интересы направмены. У одних интересов вероятность достижения блага максимальная, поскольку они имеют урегулированный правом или вытекающий из естественного хода жизни определенный механизм реализации, ведущий их к бцагу, такие интересы считаются обеспеченными субъективными правами. У других интересов вероятность того, что деятельность заинтересованного мица приведет к желаемому результату, минимальна ввиду того, что механизм их реализации неопределенен, и такие интересы, не опосредованные субъективными правами, могично называть законными интересами. Существует и третий вид правовых интересов - интересы, вероятность достижения объекта у которых изначально минимальна, но симой правоприменительного акта может стать максимальной, обрести механизм реализации в виде субъективного права. Такие интересы автор предлагает именовать промежуточными.

Реализация правовых интересов имеет разную значимость дия общества. Реализация (или нереализация) одних интересов важна только дия участников конкретного правоотношения и потому регулируется частным правом, в то время как реализация других интересов имеет значи-

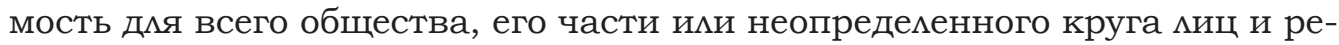
гулируется публичным правом.

Таким образом, автор настоящего исследования полагает, что в основе демения права на частное и публичное находится степень общественной значимости (соответственно частная ими общая) реализации регулируемого правом (правового) интереса.

Интересами, реализация которых может иметь общественное значение, способны обладать как публичные субъекты (общество, его часть, неопредеменный круг миц), так и частные (граждане и организации), при этом разцичие между первыми и вторыми состоит в том, что первые непосредственно не участвуют в реализации таких интересов, от их имени действуют уполномоченные субъекты; вторые же реализуют публично-правовые интересы самостоятельно. Данный тезис позволиц показать полный состав обладателей публично-правовых интересов и их возможный статус в пубцично-правовых отношениях (вцастный, подвцастный, равный).

В одной из более ранних публикаций автором была показана система способов защиты правовых интересов, опирающаяся на то, какие этапы проходит правовой интерес в процессе реализации и какие нарушения могут произойти на каждом из них [Бурмистрова, С. А., с. 9293].

В настоящей статье автор отстаивает идею о том, что реализация пубцично-правового интереса предполагает прохождение тех же этапов, что проходят частноправовые интересы. Однако обладатели частноправовых 
интересов всегда равны, обладатели же публично-правовых интересов могут занимать в правоотношении вцастное, подвцастное и равное с другим участником положение. Это, в свою очередь, означает наличие трех (соответствующих властному, подвцастному и равному статусу субъектов публично-правовых отношений) форм реализации публично-правовых интересов, они же - формы публично-правовой деятельности. Соответственно, трехкратно множится число путей, которыми могут быть нарушены публично-правовые интересы.

В настоящей работе показано, какие меры и мероприятия, направменные на защиту публично-правовых интересов, соответствуют формам публично-правовой деятельности властных, подвластных и равных участников публично-правовых отношений.

\section{Резуиьтаты нссиедования}

Дия решения проблемы системности способов (в том числе мер и мероприятий) защиты публично-правовых интересов необходимо попытаться решить проблему критерия демения права на частное и публичное, поскольку без построения полной картины публично-правовых интересов невозможно понять весь спектр их возможных нарушений и вести работу по систематизации способов борьбы с такими нарушениями.

Интерес зарубежных исследователей к проблеме разграничения права на публичное и частное постоянен. Предметом изучения выступают как общетеоретические [Pound, R., 1989; Cebera, A., 2014; Sunstein, C., 1986; Marshaw, J., 1989], отраслевые [Sunstein, C., 1985], так и прикладные аспекты проблемы [Riekkinen, M., 2016; Armstrong, S., 2016; Backer, L., 2008; Perez, A., 2001].

Довоцьно много времени прошло с тех пор, как Р. Иеринг предложил для разграничения частного и публичного права использовать совокупность критериев (характер интереса, основание и способ защиты) [Иеринг, Р., 1875, с. 181-183].

В современном зарубежном праве существуют примеры использования дия разграничения публичного и частного права как одиночных критериев, так и их совокупностей.

Например, Leslie Mulholland полагает, что в основе частного права находится свобода субъектов в выборе ими вариантов своего поведения, в то время как пубцичное право устанавливает строгие правила, регулирующие содержание и порядок осуществления поведения субъектов общественных отношений [Mulholland, L., 1993].

Точка зрения Randy Barnett явцяется примером того, как задачу разграничения публичного права и частного предлагается решить с помощью набора критериев [Barnett, R., 1986]. Ученый полагает, что частное и публичное право имеют разиичное правовое регулирование следующих четырех аспектов: 
1) значение, которое имеет правоотношение в обществе, - общее или частное;

2) $и$ ио, имеющее право обращения за защитой, - уполномоченное или мицо, обращающееся за защитой собственных прав и интересов;

3) субъекты, устанавцивающие правила поведения. В публичном праве правила, по которым возникает и развивается правоотношение, установцены нормативно, в частном же сценарий развития правоотношения

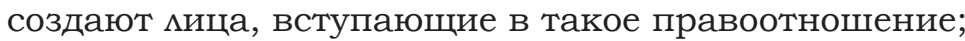

4) процедура принудительной реализации порядка, по которому должно было развиваться правоотношение. В публичном праве для указанной цели используются вмастные институты государства. Частное право допускает использование как публично-правовых, так и частноправовых институтов защиты.

В отечественной правовой науке на текущий момент имеется несколько подходов к выдемению критерия деления права на публичное и частное.

1. Субъектный состав

$\Lambda$. А. Шарнина отмечает, что публичные интересы принадлежат обществу, неопредеменному количеству мюдей [Шарнина, $\Lambda$. А., 2005, с. 4-6].

А. Ю. Аомаев в качестве характерного признака публичного интереса выдвигает неперсонифицированность его носителя, в силу чего в этой роли может выступать не только общество в целом или государство, но и группа граждан и гражданин [Аомаев, А. Ю., 2012, с. 5-7].

Согласно третьей вариации названного подхода частное право регулирует правоотношения граждан (подданных) между собой, т. е. правоотношения между мицами, подчиненными не один другому, а органам публичной вцасти и в этом смысле равными друг другу. Публичное же право регулирует правоотношения, где одной из сторон обязатемьно является

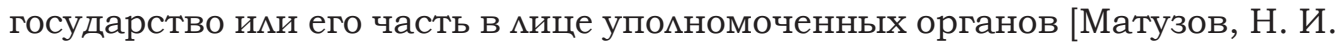
и Малько, А. В., 2004, с. 320].

2. Метод построения правоотношений (теория субординаиии и координации)

По мнению сторонников этого подхода, правоотношения между юридически равными субъектами регулируются частным правом, а правоотношения между юридически властвующим и подчиненным (подвцастным) - правом публичным [Борисова, $\Lambda$. В., 2013, с. 15].

3. Способ зашиты прав участников

Согласно данному подходу инициатива защиты частноправовых интересов принадлежит заинтересованному мицу, в то время как защита пубцично-правовых интересов осуществцяется не в инициативном порядке, а по нормативному предписанию [Муромцев, С. А., 2004, с. 169].

4. Характер интереса

В соответствии с данной позицией частное право направ ено на удовметворение и охрану индивидуальных интересов, а публичное - общих интересов [Сокомова, С. С., 2008, с. 324]. 
По мнению автора настоящей работы, все приведенные выше точки зрения опираются на второстепенные, не являющиеся сущностными признаки публичного и частного права. Думается, в основе разграничения права на частное и публичное межит значение правового интереса, реализация которого регулируется тем или иным правом. Реализация правового интереса может иметь общее, важное для всего общества или его значительной части значение (и тогда такие отношения регулируются публичным правом) или частное, важное только дия участников данного правоотношения значение (и тогда отношения регулируются частным правом).

А субъектный состав правоотношения, метод построения правоотношения, способ защиты прав участников и характер интереса в том значении, которое им придают процитированные авторы, являются уже вторичными признаками предмета регулирования публичного и частного права.

При вниматецьном рассмотрении оказывается, что как в публичноправовых, так и в частноправовых отношениях участвуют, по сути, одни и те же субъекты. Не случайно Пленум Верховного Суда Российской Федерации в п. 75 Постановцения "О применении судами некоторых положений раздема I части первой Гражданского кодекса Российской Федерации" от 23 июня 2015 г. № 25² разъясниц, что нарушение сделкой, не соответствующей закону, прав публично-правового образования не свидетельствует о том, что имеет место нарушение публичных интересов.

Метод построения правоотношения также не явцяется определяющим признаком, поскольку публично-правовые отношения могут быть основаны как на подчинении, так и на равенстве субъектов. Примером последних могут служить правоотношения в сфере передачи отдемьных пуб-

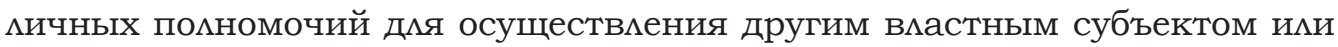
мицом, не входящим в структуру государственного ими муниципального аппарата; правоотношения в сфере межбюджетного кредитования и др. Утверждать, что такие правоотношения, будучи основанными на равенстве участников, преследуют частноправовой интерес и регулируются частным правом, было бы в корне ошибочно.

Способ защиты прав участников правоотношения в том смысле, что вкцадывают в это понятие авторы указанного критерия, также не может служить критерием разграничения права на частное и пубцичное, потому что он не учитывает того, что публично-правовые интересы (интересы, реализация которых имеет значение для всего общества) могут принадмежать индивидуальным субъектам (гражданам или юридическим мицам). Такие субъекты самостоятемьно принимают решение об обращении за защитой интересов, без какого бы то ни было побуж-

2 Бюмметень Верховного Суда Российской Федерации. 2015. № 8. 
дения к этому со стороны законодатемьства. Примером может служить все то же обращение за оспариванием нормативных правовых актов

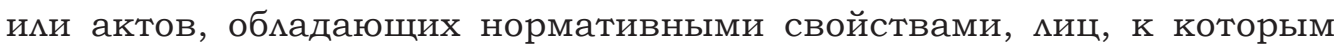
бым применен такой акт ими которые явцяются участниками регулируемых актом правоотношений.

Четвертый из приведенных выше критериев - характер интереса - в своем наименовании возражений не вызывает. Не можем согмаситься с тем смыслом, что вкладывается в упомянутое понятие. С. С. Соколова [2008, с. 324], на наш взгляд, повторима ошибку, допускаемую и другими исследователями: допустила смешение двух критериев - субъект (носитель) интереса и характер интереса. В частности, Е. В. Храмова в своем диссертационном исследовании пишет: “...по сфере правового регулирования выдемяются частный, частно-публичный и публичный интересы", а публично-правовой интерес вкцючает в себя две видовые категории: государственный и общественный интересы [Храмова, Е. В., 2011 , с. 8].

В действитецьности же носителями, обладатемями интересов являются:

- индивидуальные (они же - частные, т. е. граждане и организации) субъекты, выражающие и собственными действиями реализующие свой

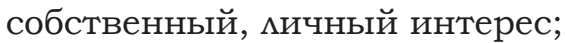

- общие (они же - публичные, состоящие из трудно определимого множества единиц: общество, его значительная часть, неопредеменный круг миц) субъекты, интересы которых представцяют и реализуют уполномоченные вцастные органы и мица, а непосредственные обладатеми интереса являются мишь выгодоприобретателями результатов реализации принадлежащих им интересов уполномоченными субъектами.

И те и другие выдеменные согласно субъекту-носителю интересы могут иметь значимость как дмя всего общества (и тогда они регулируются публичным правом), так и только дмя участников конкретного правоотношения (и в этом случае они регулируются частным правом).

Следовательно, по субъекту интересы делятся на частные и публичные, а по характеру - на частноправовые и пубцично-правовые.

В ходе работы над настоящей статьей автору не удамось отыскать трудов зарубежных авторов, которые бы решали задачу приведения в систему существующих способов защиты публично-правовых интересов. Были обнаружены труды, посвященные отдемьным способам защиты публично-правовых интересов, например, таким, как неприменение судом закона, который представцяется судье нарушающим конституцию, и разрешение спора с опорой непосредственно на нормы конституции государства [Marshaw, J., 1979].

В отечественной правовой науке ведется работа по обоснованию как отдемьных, так и совокупности способов защиты пубцично-правовых интересов. 
В частности, А. В. Аргуновым [2017; 2019] и В. В. Аргуновым [2017] последовательно отстаивается идея о том, что публично-правовые интересы домжны получать защиту путем признания особых фактов и состояний.

А. Б. Зеленцов [2012, с. 127-128] в основу создания перечня административных исков поместиц весьма обширный состав способов защиты субъективных публичных прав:

1) иски о законности или о признании недействительными административных актов (решений и действий) органов публичной власти;

2) иски о восстановлении права или о полном судебном разбирательстве, которые подразделяются на иски: а) об установцении, изменении или прекращении административного правоотношения; б) о возмещении ущерба, причиненного неправомерными действиями администрации; в) о подтверждении или признании какого-цибо субъективного публичного права; г) об исполнении обязательства; д) об издании административного акта (совершении действия), в котором заинтересован истец;

3) административно-наказательные иски (о привлечении к административной ответственности и об оспаривании решений о привлечении $\mathrm{K}$ административной ответственности);

4) иски в связи со спорами о компетенции органов публичной администрации;

5) иски по спорам, вытекающим из административных договоров.

Усилия уважаемых ученых, несомненно, имеют важное значение дмя развития правовой науки. Тем не менее, как представцяется, работа по систематизации способов защиты публично-правовых интересов еще не завершена и требует продомжения.

В предшествующих работах автора настоящей статьи было обосновано, что реализация правовых интересов представляет собой процесс, состоящий из последовательно сменяющих друг друга стадий (образно выражаясь, подобно жизненному циклу живого организма), в каждой из которых объект реализации по-своему уязвим и потому может пострадать определенным образом. Это такие стадии, как:

- появление оснований возникновения правоотношения;

- возникновение правоотношения;

- реализация интереса одной из сторон;

- реализация интереса обеими сторонами;

- прекращение правоотношения.

Исходя из того, какие повреждения могут быть причинены интересу в каждой из стадий его реализационного цикла, была предложена система общих (применимых к тересов, состоящая из таких способов, как:

- создание условий дмя реализации;

- признание;

- предотвращение нарушения; 
- пресечение нарушения;

- $и$ ивидация последствий нарушения [Бурмистрова, С. А., 2019].

Существо отдемьных из способов защиты также было освещено в предшествующих публикациях автора [Бурмистрова, С. А., 2018а; Бурмистрова, С. А., 2018b].

Нет оснований полагать, что реализационный цики публично-правовых интересов отличается от реализационного цикла интересов частноправовых. Вместе с тем реализация публично-правовых интересов имеет существенные особенности, состоящие в том, что участник публично-правового отношения может иметь в таком правоотношении один из трех возможных статусов: вцастный, подвцастный и равный. Этим статусам соответствуют определенные формы публично-правовой деятемьности:

1) властным субъектам:

- издание нормативных правовых актов и актов, обладающих нормативными свойствами;

- издание индивидуальных властных актов (ненормативных правовых актов, принятие решений, совершение действий (бездействия);

2) подвцастным субъектам:

- обращение к вцастным субъектам за изданием индивидуальных вмастных актов;

- соблюдение, исполнение, использование положений, содержащихся в нормативных правовых актах, актах, обладающих нормативными свойствами, и индивидуамьных вцастных актах;

3) равным субъектам:

- заключение, исполнение, изменение, расторжение публично-правовых согмашений.

Совместив общие способы защиты правовых интересов с тем, в каких формах протекает реализация публично-правовых интересов, получаем полную картину способов и мер зашиты публично-правовых интересов в иивилистическом проиессе:

1) создание условий дмя реализации публично-правовых интересов, осуществцяется посредством признания фактов:

- явцяющихся основанием возникновения опасного для общества правоотношения (такого, как свободное распространение материалов, содержащих информацию, распространение которой запрещено; свободное перемещение по территории государства мица, склонного к повторному совершению общественно опасных деяний, и др.);

- издания нормативного правового акта, в том числе конкретного содержания;

- издания индивидуального вцастного акта, в том числе опредеменного содержания;

- обращения к властным субъектам за изданием индивидуальных вцастных актов; 
- соблюдения, исполнения, использования положений, содержащихся в нормативных правовых и индивидуальных властных актах;

- заключения, исполнения, изменения, расторжения публично-правового согмашения;

2) признание публично-правового интереса, реализуется посредством признания:

- публичного правоотношения;

- права у административного истца (заявителя);

- обязанности у административного ответчика (противоположного заинтересованного мица);

- характеристик объекта правоотношения;

3) предотвращение нарушения пубцично-правового интереса, должно осуществляться путем:

- признания нормативного правового акта, не вступившего в сику, не подмежащим применению;

- признания ненормативного правового акта, не вступившего в силу, незаконным;

4) пресечение нарушения, реализуется посредством:

- признания действующего нормативного правового акта недействующим; обязание к принятию замещающего нормативного правового акта (если законодатемьно установцена такая обязанность) в опредеменный срок;

- признания вступившего в силу ненормативного правового акта недействитемьным, решения, действия (бездействия) незаконными; опредемение содержания акта, решения, действия, которые надмежит совершить дия устранения нарушения, и обязания к такому поведению;

- признания действий (бездействия) участника публично-правового согмашения незаконными; опредемения содержания действия (бездействия), которое надлежит совершить участнику публично-правового соглашения дмя устранения нарушения; обязание к совершению такого действия (бездействия);

- пресечения действий (бездействия) подвцастного участника публично-правового отношения; принуждения к исполнению пубцично-правовой обязанности;

5) миквидация последствий нарушения, достигается применением таких мер, как:

- признание незаконным нормативного правового акта, отмененного до вступления в силу или во время действия;

- признание незаконными отмененного или измененного ненормативного правового акта, решения, действия (бездействия);

- применение к участникам публично-правовых соглашений мер публично-правовой ответственности;

- привлечение подвцастных участников публично-правовых отношений к административной ответственности. 


\section{Обсуждение и закАючение}

Таким образом, в рамках настоящей работы автор попытался обосновать критерий, в соответствии с которым следует отграничивать пубмично-правовые интересы от частноправовых; показать полную картину таких интересов (вкАючающую интересы вцастных, подвцастных, равных участников публичных правоотношений); продемонстрировать, как выглядит реализационный цикл публично-правовых интересов и в чем состоят отличия реализации публично-правовых интересов от осуществления частноправовых; показать, из чего состоит полная система способов и соответствующих способам мер и мероприятий по защите публично-правовых интересов.

Полученные результаты могут послужить основой для упорядочивания процессуальных средств защиты публично-правовых интересов; совершенствования системы основных производств по защите пубцично-правовых интересов в административном судопроизводстве и производстве по демам, возникающим из административных и иных публичных правоотношений, арбитражного процесса.

\section{Список использованной митературы}

Аргунов А. В. Особое производство в административном судопроизводстве // Пробцемы судопроизводства по делам, возникающим из гражданских и административных правоотношений : сб. ст. по материалам междунар. науч.-практ. конф., Санкт-Петербург, 26 окт. 2016 г. СПб. : Петрополис, 2017. С. 34-40.

Аргунов А. В. Производство по демам о признании информационных материалов экстремистскими // Проблемы судопроизводства в суде первой инстанции по гражданским, арбитражным и административным демам : сб. ст. по материалам Междунар. науч.-практ. конф., Санкт-Петербург, 12 окт. 2018 г. / под общ. ред. А. В. Войтович, В. И. Кайнова. СПб. : Петрополис, 2019. С. 31-39.

Аргунов В. В. Каким быть особому производству по административным делам: к проекту изменений в КАС РФ // Вестник экономического правосудия Российской Федерации. 2017. № 3. С. 62-75.

Борисова $\Lambda$. В. Об основаниях (критериях) деления права на частное и публичное // Вестник МГОУ. Сер.: Юриспруденция. 2013. № 1. C. 11-17.

Бурмистрова С. А. Защита правовых интересов в гражданском и административном судопроизводстве. М. : Юрлитинформ, 2020. 280 c.

Бурмистрова С. А. Система способов защиты правовых интересов // Законы России: опыт, анализ, практика. 2019. № 2. С. 91-94. 
Бурмистрова С. А. Создание условий для реализации правовых интересов как способ их защиты / / Журнал российского права. 2018а. № 3 (255). C. 17-27.

Бурмистрова С. А. Устранение угрозы нарушения и пресечение нарушения как способы защиты правовых интересов // Арбитражный и гражданский процесс. 2018b. № 5. С. 25-29.

Гатин А. А. Производство по делам об оспаривании ненормативных правовых актов, решений, действий (бездействия) государственных органов, органов местного самоуправления, иных органов, должностных миц, государственных и муниципальных служащих в гражданском и арбитражном процессе : автореф. дис. ... канд. юрид. наук. Казань, 2011. 22 с.

Зеленцов А. Б. Субъективное публичное право : учеб. пособие. М. : РУДН, 2012. 146 с.

Иеринг Р. Борьба за право / пер. С. И. Ершова. М.: Феникс, 1991. $64 \mathrm{c}$.

Иеринг Р. Дух римского права на разцичных ступенях его развития. СПб.: Тип. В. Безобразова и комп., 1875. 321 с.

Иеринг Р. Цель в праве / пер. Н. Ф. Дерюжинского, Н. В. Муравьева. СПб.: Изд-во Н. В. Муравьева, 1881. 425 с.

Аомаев А. Ю. Публичный интерес как правовая категория : автореф. ... дис. канд. юрид. наук. Казань, 2012. 22 с.

Матузов Н. И. Теория государства и права : учебник. М. : Юристь, 2004. 512 c.

Муромцев С. А. Определение и основное разделение права. СПб. : Изд. дом С.-Петерб. гос. ун-та : Изд-во юрид. фак-та СПбГУ, 2004. 224 c.

Никитин С. В. Судебный нормоконтроль в гражданском процессе и арбитражном процессе: вопросы теории и практики : автореф. дис. ... д-ра юрид. наук. М., 2010. 49 с.

Соколова С. С. Интерес как критерий разграничения частных и публично-правовых отношений // Известия Российского государственного педагогического университета им. А. И. Герцена. 2008. № 82-1. С. 323-325.

Хахалева Е. В. Контроль судов общей юрисдикции за деятельностью органов исполнительной власти и их должностных миц : автореф. дис. ... д-ра юрид. наук. Ростов-н/Д, 2011. 39 с.

Храмова Е. В. Защита публично-правовых интересов в арбитражном процессе : автореф. дис. ... канд. юрид. наук. Саратов, 2011. 22 с.

Шарнина $\Lambda$. А. Частные и публичные интересы в конституционном праве / / Конституционное и муниципальное право. 2005. № 4. С. 4-6. 
Armstrong S. Clothing the gap on moral relativity: comparing human rights regimes in the United States and the Russian Federation // Russian Law Journal. 2016. Vol. 4, no. 1. P. 98-128.

Backer L. The Private Law of Public Law: public authorities as shareholders, golden shares, sovereign wealth funds, and the Public Law element in Private choice of Law // Tulane Law Review. 2008. Vol. 82. P. 1-67.

Barnett R. Four senses of the Public Law-Private Law distinction // Harvard Journal of Law \& Public Policy. 1986. Vol. 9. P. 267-276.

Cebera A. The paradigms for distinguishing between Private Law and Public Law // Nauki Społeczne. 2014. Vol. 1, no. 8. P. 53-59.

Marshaw J. Constitutional deregulation: notes toward a public, Public Law // Tulane Law Review. 1979. Vol. 54. P. 849-876.

Marshaw J. The economics of politics and the understanding of Public Law / / The University of Chicago Law Review. 1989. Vol. 65. P. 123-160. Mulholland L. The difference between Private and Public Law // Jahrbuch für Recht und Ethik. Annual Review of Law and Ethics. 1993. Vol. 1. P. 113-158.

Perez A. The international recognition of judgments: the debate between Private and Public Law solutions // Berkeley Journal of International Law. 2001. Vol. 19. P. 44-89.

Pound R. Public Law and Private Law // Cornell Law Quarterly. 1939. Vol. XXIV, no. 4. P. 469-482.

Riekkinen M. Public participation and the rights of the child: reflection on international law standard in the legal system of Russian Federation // Russian Law Journal. 2016. Vol. 4, no. 4. P. 7-26.

Sunstein C. Interest groups in American Public Law // Stanford Law Review. 1985. Vol. 38. P. 29-87.

Sunstein C. Legal interference with private preferences / The University of Chicago Law Review. 1986. Vol. 53, no. 4. P. 1129-1174.

\section{References}

Argunov, A. V., 2017. [Special proceedings in administrative proceedings]. In: Problemy sudoproizvodstva po delam, voznikayushchim $i z$ grazhdanskih $i$ administratiunyh pravootnoshenij $=$ [Problems of Legal Proceedings in Cases Arising from Civil and Administrative Legal Relations]. Collection of articles based on the materials of the international scientific and practical conference, St. Petersburg, Russia, 26 October 2016]. St. Petersburg: Petropolis. (In Russ.)

Argunov, A. V., 2019 [Proceedings on recognition of information materials as extremist]. Problemy sudoproizvodstva $v$ sude pervoj instancii po 
grazhdanskim, arbitrazhnym $i$ administrativnym delam. $=[$ Problems of Legal Proceedings in the Court of First Instance in Civil, Arbitration and Administrative Cases]. Collection of articles based on the materials of the international scientific and practical conference. St. Petersburg, Russia, 12 October 2018. St. Petersburg: Petropolis. (In Russ.)

Argunov, V. V., 2017. [What should special proceedings on administrative cases be like: to the draft amendments to the Code of administrative procedure of the Russian Federation]. Vestnik ekonomicheskogo pravosudiya Rossijskoj Federacii = [Bulletin of Economic Justice of the Russian Federation], 3, pp. 62-75. (In Russ.)

Armstrong, S., 2016. Clothing the gap on moral relativity: comparing human rights regimes in the United States and the Russian Federation. Russian Law Journal, 4(1), pp. 98-128.

Backer, L., 2008. The Private Law of Public Law: public authorities as shareholders, golden shares, sovereign wealth funds, and the Public Law element in Private choice of Law. Tulane Law Review, 82, pp. 1-67. Barnett, R., 1986. Four senses of the Public Law-Private Law distinction. Harvard Journal of Law \& Public Policy, 9, pp. 267-276.

Borisova, L. V., 2013. [On the grounds (criteria) of dividing the law into Private and Public]. Vestnik Moskovskogo gosudarstvennogo oblastnogo universiteta. Ser.: Yurisprudenciya $=$ [Bulletin of the Moscow State University. Series “Jurisprudence”], 1, pp. 11-17. (In Russ.)

Burmistrova, S. A., 2018a. [Creating conditions for the implementation of legal interests as a way to protect them]. Zhurnal rossijskogo prava= [Journal of Russian Law], 3 (255), pp. 17-27. (In Russ.) DOI: 10.12737/ art_2018_3_2

Burmistrova, S. A., 2018b. [Elimination of the threat of violation and suppression of violations as ways to protect legal interests]. Arbitrazhnyj i grazhdanskij process $=$ [Arbitration and Civil Process], 5, pp. 25-29. (In Russ.)

Burmistrova, S. A., 2019. [System of ways to protect legal interests]. Zakony Rossii: opyt, analiz, praktika = [Laws of Russia: Experience, Analysis, Practice], 2, pp. 91-94. (In Russ.)

Burmistrova, S. A., 2020. Zashchita pravovyh interesov v grazhdanskom $i$ administrativnom sudoproizvodstve $=$ [Protection of legal interests in civil and administrative proceedings]. Moscow: Yurlitinform. (In Russ.) Cebera, A., 2014. The paradigms for distinguishing between Private Law and Public Law. Nauki Społeczne, 1 (8), pp. 53-59.

Gatin, A. A., 2011. Proizvodstvo po delam ob osparivanii nenormativnykh aktov, resheniy, deystviy (bezdeystviya) gosudarstvennykh organov, organov mestnogo samoupravleniya, organov mestnogo samoupravleniya, 
ofitsial'nykh lits, gosudarstvennykh $i$ munitsipal'nykh sluzhashchikh $v$ grazhdanskom $i$ arbitrazhnom protsesse $=$ [Proceedings in cases on challenging non-normative legal acts, decisions, actions (inaction) of state bodies, bodies of local self-government, other bodies, officials, state and municipal employees in the civil and arbitration process]. Abstract of Cand. Sci. (Law) Dissertation. Kazan. (In Russ.)

Jhering, R., 1875. The spirit of Roman law at various stages of its development. St. Petersburg: V. Bezobrazov Printing house and company. (In Russ.)

Jhering, R., 1881. The goal is right. St. Petersburg: N. V. Muravyov Publishing House. (In Russ.)

Jhering, R., 1991. The struggle for the right. Moscow: Phoenix. (In Russ.) Khakhaleva, E. V., 2011. Control of courts of General jurisdiction over the activities of Executive authorities and their officials. Abstract of Dr. Sci. (Law) Dissertation. Rostov-on-Don. (In Russ.)

Khramova, E. V., 2011. Protection of public-legal interests in the arbitration process. Abstract of Cand. Sci. (Law) Dissertation. Saratov. (In Russ.)

Lomaev, A. Yu., 2012. Publichnyy interes kak pravovaya kategoriya $=$ [Public interest as a legal category]. Abstract of Cand. Sci. (Law) Dissertation. Kazan. (In Russ.)

Marshaw, J., 1979. Constitutional deregulation: notes toward a Public, Public Law. Tulane Law Review, 54, pp. 849-876.

Marshaw, J., 1989. The economics of politics and the understanding of Public Law. The University of Chicago Law Review, 65, pp. 123-160.

Matuzov, N. I. and Malko, A. V., 2004. Teoriya gosudarstva $i$ prava = [Theory of state and law]. Textbook. Moscow: Yurist. (In Russ.)

Mulholland, L., 1993. The difference between Private and Public Law. Jahrbuch für Recht und Ethik. Annual Review of Law and Ethics, 1, pp. 113-158.

Muromtsev, S. A., 2004. Opredelenie $i$ osnovnoe razdelenie prava = [Definition and main division of law]. St. Petersburg: St. Petersburg State University Publishing House; Publishing House of the Faculty of Law of St. Petersburg State University. (In Russ.)

Nikitin, S. V., 2010. Sudebnyy normokontrol'v grazhdanskom protsesse $i$ arbitrazhnom protsesse: voprosy teorii i praktiki = [Judicial norm control in civil proceedings and arbitration proceedings: issues of theory and practice]. Abstract of Dr. Sci. (Law) Dissertation. Moscow. (In Russ.)

Perez, A., 2001. The international recognition of judgments: The debate between Private and Public Law solutions. Berkeley Journal of International Law, 19, pp. 44-89. 
Pound, R., 1939. Public Law and Private Law. Cornell Law Quarterly, XXIV(4), pp. 469-482.

Riekkinen, M., 2016. Public participation and the rights of the child: reflection on international law standard in the legal system of Russian Federation. Russian Law Journal, 4(4), pp. 7-26.

Sharnina, L. A., 2005. [Private and public interests in constitutional law]. Konstitucionnoe $i$ municipal'noe pravo $=[$ Constitutional and Municipal Law], 4, pp. 4-6. (In Russ.)

Sokolova, S. S., 2008. [Interest as a criterion for distinguishing private and public relations]. Izvestiya Rossijskogo gosudarstvennogo pedagogicheskogo universiteta im. A. I. Gercena $=$ [Bulletin of the Herzen Russian State Pedagogical University], 82-1, pp. 323-325. (In Russ.)

Sunstein, C., 1985. Interest groups in American Public Law. Stanford Law Review, 38, pp. 29-87.

Sunstein, C., 1986. Legal Interference with Private Preferences. The University of Chicago Law Review, 53(4), pp. 1129-1174.

Zelentsov, A. B., 2012. Sub'ektivnoe publichnoe pravo $=[$ Subjective public right]. Textbook. Moscow: RUDN. (In Russ.)

\section{Информация об авторе / Information about the author}

Бурмистрова Светмана Амександровна, кандидат юридических наук, доцент, заведующий кафедрой гражданского процессуального права Уральского филиала Российского государственного университета правосудия (Российская Федерация, 454135, г. Челябинск, ул. Энергетиков, д. 63a)

Svetlana A. Burmistrova, Cand. Sci. (Law), Associate Professor, Head of the Civil Proceedings Law Department, Ural Branch, Russian State University of Justice (63a Energetikov St., Chelyabinsk, 454135, Russian Federation).

E-mail: lelsi@yandex.ru

Дата поступления рукописи в редакцию издания: 23.10.2020; дата одобрения после рецензирования: 08.11.2020; дата принятия статьи к опубликованию: 02.02.2021.

Submitted 23.10.2020; reviewed 08.11.2021; revised 02.02.2021. 


\title{
Институт отвода судьи в гражданском процессе: исторический оспект
}

\author{
М. Е. Поскребнев \\ ФГБОУВО «РОссийский государственный университет \\ правосудия», г. Москва, Российская Федерация \\ forceline@mail.ru
}

\begin{abstract}
Аннотация
Введение. Статья посвящена исторической ретроспективе института отвода судьи в гражданском процессе. За основу исследования была взята древнеримская модель устранения (отвода) судей в республиканском и императорском периодах развития римского частного права. На базе древнеримской модели были сформированы основные элементы отвода, которые использовались автором при анализе отвода в русской и российской истории развития гражданского процесса.

Теоретические основы. Методы. Исследованы следующие исторические периоды развития института: 1) период с Соборного уложения 1649 г. на Руси до Свода законов гражданских 1832 г. в России; 2) период действия Устава гражданского судопроизводства 1864 г.; 3) советский период; 4) современный период. Российский дореволюционный и советский периоды развития института отвода судьи в гражданском процессе были рассмотрены особо. Такой подход обусловлен тем, что в эти периоды развития института правила отвода наиболее детализированы, сходны с современными правилами отвода. В исследовании использованы исторический метод, метод анализа и сравнения.

Результаты исследования. Результатами исследования являются: 1) ознакомление читателя с историей развития отвода судьи в гражданском процессе; 2) проведение сравнительного анализа развития института в разные периоды истории, формирование на этой основе выводов о генезисе отвода; 3) выявление тенденции развития института отвода, а также выдвижение предложений о перспективах его реформирования.

Современный отвод является преемником советского отвода, поэтому ему присущи все указанные в настоящей статье основные отличительные черты советского отвода. Состоявшиеся изменения отвода в новейшее время можно сгруппировать следующим образом. Во-первых, это изменения, связанные с судебной реформой: с введением в качестве основного единоличного состава рассмотрения дела; с усилением независимости судей и с расширением примирительных процедур. Эти изменения подробно изложены в статье. Во-вторых, изменение отвода, которое является следствием допущения признания судьи подозрительным в любое время судебного разбирательства, а также отсутствия ответственности для недобросовестных заявителей отвода. Это новое правило, запрещающее дважды заявлять отвод тем же лицом, по тем же основаниям. Второе изменение является попыткой современного законодателя скорректировать ошибку в правилах советского отвода, в которых был допущен отвод подозрительного судьи без ограничения во времени. Обсуждение и заключение. Дальнейшее существенное изменение правил отвода на современном этапе возможно путем перехода к коллегиальному рассмотрению гражданских дел. В таком случае отвод может быть пересмотрен кардинально, в нем может быть усилено состязательное начало с учетом исторического опыта. Однако рассмотрение
\end{abstract}


гражданских дел коллегиальным составом потребует увеличения времени на судебное разбирательство. Высокая судебная нагрузка по гражданским делам пока не позволяет этого сделать, поэтому существенные изменения возможны в отдаленной перспективе или по ограниченным категориям наиболее важных дел, например по делам о лишении родительских прав. Представляется, что в ближайшей перспективе сохранится тенденция изменения отвода косвенным образом, т. е. под влиянием отвлеченных факторов судебной реформы. В качестве борьбы с недобросовестными отводами уже в ближайшее время можно предложить следующие изменения: во-первых, ограничить во времени отводы подозрительных судей; во-вторых, ввести штраф за неподтвержденный отвод.

Ключевые слова: отвод судьи в гражданском процессе, устранение судьи, recusatio, мотивы отвода, форма отвода, относительно неспособный судья, самоотвод, недобросовестный заявитель отвода

Для цитирования: Поскребнев М. Е. Институт отвода судьи в гражданском процессе: исторический аспект // Правосудие/Justice. 2021. Т. 3, № 1. C. 86-112. DOI: 10.37399/26869241.2021.1.86-112.

\title{
The Institution of Recusal of Judges in Civil Proceedings: Historical Aspect
}

\section{Maxim E. Poskrebnev}

Russian State University of Justice, Moscow, Russian Federation For correspondence: forceline@mail.ru

\begin{abstract}
Introduction. This article is devoted to the study of the history of the development of the institution of recusal in civil proceedings. A number of separate norms of the Civil Procedure Code of the Russian Federation are devoted to the institution of recusal of a judge in civil proceedings. A correct understanding of these norms is possible with the help of their historical analysis. The study of the historical aspect of the institution of recusal of a judge in civil proceedings can be useful in developing new legislative initiatives on this issue, and can also contribute to the removal of controversial issues in this area.

Theoretical Basis. Methods. A number of historical periods in the development of judicial recusal were studied: the period from the Council Code of 1649 in Russia to the Code of Civil Laws of 1832 in Russia, the period of the Charter of Civil Proceedings of 1864, the Soviet period, and the modern period. Special attention is paid to the Russian pre-revolutionary and Soviet periods of development of the institution of judicial recusal in civil proceedings. This approach is due to the fact that in these periods of development of the Institute, the rules of withdrawal are most similar to the modern rules of withdrawal. The study uses the historical method, as well as the method of analysis and comparison.

Results. The results of the study are: familiarise the reader with the history of recusal in civil proceedings; a comparative analysis of the development of the Institute in different periods of history, the formation on this basis conclusions about the Genesis of the withdrawal; identify trends in the development of the institution of disqualification and the proposals on the prospects of its reforming.

Discussion and Conclusion. The modern recusal is a receiver of the Soviet recusal, so it has all the main distinctive features of the Soviet recusal indicated in this article. Recent changes of the recusal can be grouped as follows. First, these are changes related to the judicial reform. These changes are detailed in the article. Secondly, the change of the recusal, which is a consequence of allowing the recognition of the judge as suspicious at any time of the trial, as well as the lack of responsibility for unscrupulous applicants of the recusal. The first group of changes is the result of judicial reform in general. The second change is an attempt by the modern legislator to correct
\end{abstract}


an error in the rules of Soviet recusal, in which the recusal of a suspicious judge was allowed without a time limit.

Keywords: recusation of a judge in civil proceedings, removal of a judge, recusatio, reasons for recusation, form of recusation, relatively incapable judge, recusation, unfair recusant

For citation: Poskrebnev, M. E., 2021. The Institution of Recusal of Judges in Civil Proceedings: Historical Aspect. Pravosudie/Justice, 3(1), pp. 86-112. DOI: 10.37399/2686-9241.2021.1.86112.

\section{Введение}

В гражданском процессе судья призван защищать нарушенные или оспариваемые частноправовые интересы (ст. 2 ГПК РФ). Он должен выполнить обязанность государственного характера (осуществить правосудие), но в частноправовых, чужих интересах. Если же судья будет преследовать частноправовые интересы, то окажется действующим не в качестве органа судебной вцасти государства, а в качестве частного мица. Таким образом, судья не может исполнять свои государственные обязанности в таком деме, в котором предмет спора входит в круг его частноправовых интересов, так как этот судья может проявить необъективность. Однако судья может оказаться пристрастным не только относительно предмета спора, но и в пользу других миц, той или иной стороны по дему. Причины, побуждающие к этому судью, могут быть весьма разнообразными [Нефедьев, Е. А., 1885, с. 6]. В обоих скучаях пристрастный судья должен быть устранен от разрешения такого дема, т. е. этот судья подмежит отводу.

Институту отвода судьи в гражданском процессе посвящен ряд обособленных норм Гражданского процессуального кодекса Российской Федерации (ГПК РФ). Правильное представление об этих нормах возможно при помощи их исторического анализа. Исследование исторического аспекта института отвода судьи в гражданском процессе может быть полезным при разработке новых законодательных инициатив в этом вопросе, а также может способствовать снятию спорных вопросов в этой области.

\section{Теоретические основы. Методы}

Объектом исследования в настоящей статье выступает институт отвода судьи в гражданском процессе. Исследование объекта осуществляцось в исторической ретроспективе. За основу исследования взята древнеримская модель устранения (отвода) судей в республиканский и императорский периоды развития римского частного права. Эти два периода биполярны: одному периоду свойственно максимально частное начало (jus privatum), другому - максимально публичное начало (jus publicum), поэтому рассмотрение одного и того же явцения в этих помярно различных условиях весьма продуктивно. Исследовать измене- 
ния отвода судьи, произошедшие в связи со сменой исторических эпох в римском праве, не было необходимости, так как эти изменения уже были исследованы видным ученым Е. А. Нефедьевым [Нефедьев, Е. А., 1885]. В связи с этим мы воспользовались результатами исследований Е. А. Нефедьева дмя сравнивания частного и публичного начала в отводе судьи и вычиеними основные конструктивные элементы устранения судьи, которые использовались для ориентиров в исследовании отвода судьи в истории развития русского и российского гражданского процесса.

При рассмотрении дореволюционного периода развития института (вторая половина XIX в.) дмя мучшего уяснения функционирования отвода в это время были исследованы французские правила отвода XIX в. Сравнительный подход обусловлен тем, что французская доктрина гражданского процесса повлияла на формирование взглядов российских ученых, работавших во времена Судебной реформы 1864 г. Французский Гражданский процессуальный кодекс 1806 г. ко времени принятия Судебных уставов 1864 г. признавался иучшим в Европе [Аргунов, А. В., 2013, с. 73]. Кроме того, французская модемь отвода судьи в гражданском процессе более состязательна, чем российская модемь. Исследуя французскую модемь, мы также придерживались метода сравнения более частного (французского) и более публичного (российского) начала в развитии отвода судьи в гражданском процессе. Это сравнение позволимо сформулировать продуктивные, интересные выводы исследования.

Российский дореволюционный и советский периоды развития института отвода судьи в гражданском процессе рассмотрены особо. Такой подход обусловлен тем, что в эти периоды развития института правима отвода наиболее детализированы, сходны с современными правимами отвода. Исследование исторического аспекта развития института дало возможность увидеть перспективы развития отвода в дамьнейшем.

Таким образом, в статье использовались в основном исторический метод, метод анализа и сравнения.

\section{Резуцьтаты исследования \\ Римский период}

Устранение пристрастного судьи было известно уже римскому праву в период Республики. В ординарном процессе (ordo judiciorum privatorum), на этапе перехода из стадии in jure в стадию in judicio, магистрат (претор) выдавал норму (формулу), по которой затем следовало судиться в in judicio. В формуле определялись не только норма, но и судья (народный представитель) для стадии in judicio. Судью выбирали стороны из опреде-

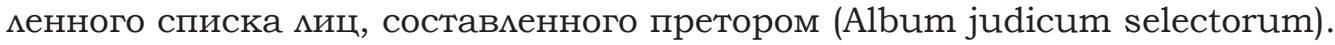




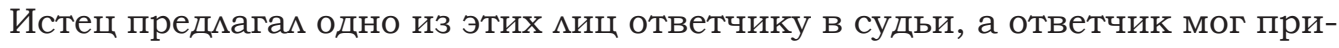
нять его ими отвергнуть. Такой отказ ответчика признать судьей то мицо, на которое указал истец, был устранением ими отводом cyдьи (recusatio) [Нефедьев, Е. А., 1885, с. 9-10]. Ответчик здесь не обязан был указывать

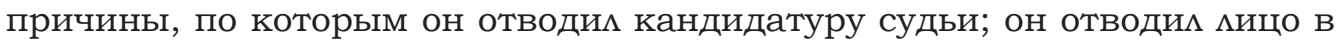
судьи мишь потому, что не ждал от него справедиивого решения. Пред-

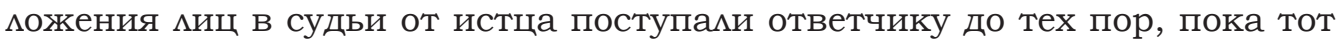
не одобрял соответствующую кандидатуру. Принятие ответчиком в судьи мица, предложенного истцом, означало, что обе стороны согласны судить-

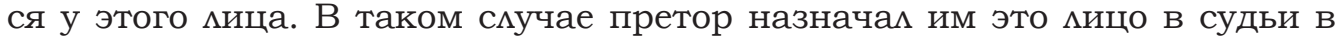
стадии in judicio для дальнейшего разрешения дема, т. е. заключалось litis contestatio относитемьно выбранного судьи [Хвостов, В. М., 1919, с. 227]. Поскоцьку судья был добровоцьно выбран обеими сторонами, после litis contestatio стороны не только не могми заявцять ему отводы, но и домжны были его решение принять добровольно.

Если ответчик змоупотреблял своим правом отводить судей, предлагаемых истцом, и претор убеждался в том, что ответчик делает это сознательно с целью уклониться от процесса, то претор признавал такого ответчика indefensus (незащищающимся), вследствие чего истец вводицся во вцадение имуществом ответчика [Нефедьев, Е. А., 1885, с. 10].

Таким образом, отвод здесь выполнял роль некой формы избрания судьи дия разбора дема. Как видно, эта форма была во многом диспозитивного свойства, соответствующей римскому частному праву (jus privatum) [Муромцев, С. А., 2004, с. 694].

$\mathrm{K}$ магистрату не мог быть применим отвод (recusatio), поскольку, вопервых, этот отвод выступал диспозитивной формой избрания судьи, а магистрат не избирался сторонами; во-вторых, в отводе магистрата не было для сторон и практической надобности, так как он не разбирал демо

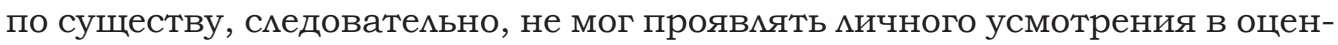
ке фактической стороны его, так что пристрастные отношения его к той или другой стороне не могли оказывать влияния на исход процесса. Что же касается взгляда магистрата на юридическую сторону процесса, который он формулировал в первой стадии in jure, то здесь стороны домжны были подчиниться ему, даже если он и был неправимьным [Нефедьев, Е. А., 1885, с. 16]. Однако магистрат домжен быц уклониться от исполнения своих обязанностей в деле, где он сам являлся стороной, а также в деме своей жены, детей, отпущенников и других $и ц$, состоящих под его отеческой вмастью.

В императорский период римского права в экстраординарном процесce (extra ordinem) раздемение процесса на две части (in jure и in judicium) бымо устранено, поэтому в стадии judicium стороны больше не избирами судью [Покровский, И. А., 1998, с. 219-220; Боголепов, Н. П., 2004, с. 495]. В этот период магистрат сам рассматривал дело целиком. Следовательно, отвод как форма избрания судьи был отменен. Однако отвод 
стал применяться в другой форме: им можно было отстранить подозритемьного магистрата.

В период Республики в римском праве стороны добровольно выбира$\Lambda$ судью и добровольно подчинялись ему. Этот процесс бым в большей степени частным (jus privatum). В императорский период стороны уже никого не выбирали, магистрат им был навязан, и сторонам приходимось мириться с его вцастью (компетенцией), признавать ее императивно (публично), поэтому этот процесс был в большей степени процессом публичного права (jus publicum) [Муромцев, С. А., 2004, с. 695; Покровский, И. А., 1998, с. 221]. Отвод, однако, не был отменен и в этом смысме оставался jus privatum первого периода, поскольку хотя и не позво$\Lambda я \Lambda$ выбрать магистрата, но все же позволяц высказать нежемание принять власть магистрата в процессе. В силу публичности процесса здесь не может уже идти речь и о немотивированном отводе, как это было в частном процессе периода Республики. Сторона, заявившая отвод, обязана была указать, по каким конкретно причинам она не желала вцасти магистрата в процессе, а именно - в чем подозревался магистрат относительно компетенции по дему. Эти причины были дмя сторон заранее определены. Весьма пубцичным было и то, что, если даже магистрат признавался подозрительным к делу, он не устранялся от рассмотрения дела вовсе. Дия рассеивания подозрений к нему добавляли еще одного судью (conjudex), и дело рассматривалось ими совместно [Нефедьев, Е. А., 1885, c. 20]. Учитывая то, что прежний частный порядок избрания судьи был нарушен, отвод дозволялось заявить уже не только ответчику, но и истцу. Кроме того, несмотря на то что стороны отводом больше не выбирали судью, они все равно после litis contestatio не могли заявцять отвод магистрату.

В этот период имело место и исключение: если магистрат в симу сильной занятости не мог рассмотреть дело сам, он мог передать его на рассмотрение другого чиновника (помощника). В таком случае к этому чиновнику могли быть применены некоторые элементы порядка предыдущего периода. Например, как и раньше, стороны могли отводить этого чиновника без объяснения причин. Если отвод удовлетворялся, то чиновник заменялся арбитрами, которых обязаны были избрать стороны [Нефедьев, Е. А., 1885, с. 20].

Из этого краткого обзора можно усмотреть отдемьные конструктивные элементы, которые составцяли устранение судьи в Древнем Риме:

1) форма отвода:

- отвод как форма избрания судьи заявлялся частному судье ответчиKOM;

- отвод как форма отстранения от рассмотрения дема заявцялся магистрату сторонами;

- самоотвод заявцялся и частным судьей, и магистратом;

2) мотивация отвода: 
- немотивированный отвод заявцялся частному судье;

- мотивированный отвод заявцялся магистрату;

3) ограничение отвода во времени:

- отвод возможно было заявить только до litis contestatio в обоих периодах, хотя относительно магистрата сторонам домжно было быть разрешено заявить отвод и после litis contestatio;

4) положитецьный результат отвода:

- замена частного судьи;

- присоединение к подозрительному магистрату еще одного магистрата, не вызывающего подозрений.

Дия наглядности рассмотрим эти эмементы в таблице:

таблииа 1 / Table 1

\begin{tabular}{|c|c|c|}
\hline $\begin{array}{c}\text { Конструктивные } \\
\text { элементы устранения } \\
\text { судьи / Structural } \\
\text { elements of the judge's } \\
\text { recusal }\end{array}$ & $\begin{array}{c}\text { Период Республики, с } \\
\text { преобладанием в процессе јus pri- } \\
\text { vatum / Period of the Republic, with } \\
\text { jus privatum dominating the process }\end{array}$ & $\begin{array}{c}\text { Императорский период, с } \\
\text { преобладанием в процессе јus publicum } \\
\text { / Imperial period, with the jus publicum } \\
\text { dominating the process }\end{array}$ \\
\hline \multirow[t]{2}{*}{$\begin{array}{l}\text { 1. Форма отвода / } \\
\text { Form of recusal }\end{array}$} & $\begin{array}{l}\text { отвод как форма избрания } \\
\text { судьи заявлялся частному судье } \\
\text { ответчиком / recusal as a form of } \\
\text { election of a judge was made to a } \\
\text { private judge by the defendant }\end{array}$ & $\begin{array}{l}\text { отвод как форма отстранения от } \\
\text { рассмотрения дела заявлялся } \\
\text { магистрату сторонами / recusal as a } \\
\text { form of disqualification was made to the } \\
\text { magistrate by the parties }\end{array}$ \\
\hline & \multicolumn{2}{|c|}{ Самоотвод / Self-recusal } \\
\hline $\begin{array}{l}\text { 2. Мотивация отвода / } \\
\text { Ground for recusal }\end{array}$ & $\begin{array}{l}\text { немотивированный отвод } \\
\text { заявлялся частному судье / an } \\
\text { unmotivated recusal was made to a } \\
\text { private judge }\end{array}$ & $\begin{array}{l}\text { мотивированный отвод заявлялся } \\
\text { магистрату / a reasoned recusal was } \\
\text { made to a magistrate }\end{array}$ \\
\hline $\begin{array}{l}\text { 3. Ограничение отво- } \\
\text { да во времени / Time } \\
\text { restriction of recusal }\end{array}$ & \multicolumn{2}{|c|}{$\begin{array}{l}\text { отвод возможно было заявить только до litis contestatio в обоих периодах, } \\
\text { хотя относительно магистрата в императорский период сторонам должно } \\
\text { было быть разрешено заявить отвод и после litis contestatio / recusal could } \\
\text { only be made before litis contestatio in both periods, although in relation to a } \\
\text { magistrate in the imperial period the parties had be allowed to make a recusal } \\
\text { even after litis contestatio }\end{array}$} \\
\hline $\begin{array}{l}\text { 4. Положительный } \\
\text { результат отвода / A } \\
\text { positive outcome of } \\
\text { recusal }\end{array}$ & $\begin{array}{l}\text { замена частного судьи / } \\
\text { replacement of a private judge }\end{array}$ & $\begin{array}{l}\text { присоединение к подозрительному } \\
\text { магистрату еще одного магистрата, } \\
\text { не вызывающего подозрений / joining } \\
\text { a suspicious magistrate with another } \\
\text { magistrate who is beyond suspicion }\end{array}$ \\
\hline
\end{tabular}

Как видно, конструктивные эмементы устранения судьи в римском праве изменились в связи с изменением самого римского права: в нем усилилось публичное начало (jus publicum) и, соответственно, ослабло частное начало (jus privatum). 


\section{Период с Соборного уложения 1649 г. на Руси до Сөода законов гражданских 1832 г. в России}

При царе Алексее Михайловиче судьями выступали воеводы, которые назначались на эту должность милостью государя и отстранялись им без объяснения причин [Дмитриев, Т., 1859, с. 303]. Таким образом, воевода был цицом административного ведомства, поэтому его вполне можно сравнить с римским магистратом периода Империи. Как и в Риме, отвод воевод быц явцением скорее публичного свойства (jus publicum), т. е. его конструктивные элементы были во многом сходны с элементами, характерными для отвода в римском праве времен императора, с которыми мы ознакомились в таблице.

Как и в Риме в императорский период, на Руси по форме отвод бым устранением государственного чиновника от рассмотрения дела; отстранить можно было конкретного судью мибо перенести дело в другой город [Дмитриев, Т., 1859, с. 395]. Отвод на Руси должен был быть мотивированным. Мотивы тяжущегося были следующие: мичная его вражда с судьей, дружба ими родство судьи с противником [Дмитриев, Т., 1859, c. 395]. Эти мотивы, по мнению Е. А. Нефедьева, были достаточно неопределенными, поэтому при рассмотрении отвода их можно было широко толковать. Кроме того, на высших судей, заседавших в приказах, отводы рассматривал сам царь, который, как полагал Е. А. Нефедьев, руководствовался указанными мотивами в меньшей степени. Царь предпочитал отводом решать вопрос о том, можно ми вообще челобитчику искать или отвечать перед тем судьей, против которого было заявмено подозрение. Челобитные приказы, куда подавались отводы на областных судей, перенимая практику царя, также действовали больше на свое усмотрение, чем руководствовались мотивами для отвода, изможенными в законе [Hефедьев, Е. А., 1885, с. 89].

Как и в Риме, во времена Уможения на Руси было установлено ограничение отвода во времени. Однако на Руси отвод во времени ограничивался не litis contestatio, а решением суда [Нефедьев, Е. А., 1885, с. 89]. Соответственно, если тяжущийся до вынесения решения не заявлял отвод, то он не мог требовать пересмотра этого решения только на основании того, что считал судью подозрительным, а именно: тяжущийся должен был заявить о подозрении в суде до постановцения решения, а значит, если он в суде промолчал, то признал судью неподозрительным. В свою очередь, отвод после решения в форме жалобы в высокой степени вызывал подозрение в добросовестности такого жалобщика, который тем самым мог волокитить это демо.

Сцедует отметить, что после решения все же возможен был еще один специфический отвод. Скорее это быц даже не отвод, а обвинение в угомовном порядке. Тяжущийся мог заявить на судью, если тот судиц пристрастно по посулам. В таком случае жалобщику давали с судьей очную ставку, потом проводими допрос свидетемей, которых каждый приводим 
в свою пользу. УАиченного в пристрастии судью подвергали взысканию в пользу тяжущегося тройной цены иска и уголовному наказанию. Если же жалоба оставалось неудовцетворенной, жалобщика подвергали взысканию бесчестия в пользу судьи в тройном размере иска, а также наказывали кнутом [Дмитриев, Т., 1859, с. 438].

Самоотвод единоличного судьи на Руси времен Уможения был недопустим. Однако самоотвод члена комлегиального суда - Боярской Думы бым возможен. Отводимые члены должны были выйти из присутствия, не дожидаясь заявления отвода, когда разбирались дела их самих или близких им мюдей [Кавемин, К., 1844, с. 81].

Положительным результатом отвода единоличного судьи становилась замена судьи. Демо передавалось другому судье из ближайшего города в пределах 150 верст [Нефедьев, Е. А., 1885, с. 86].

Отвод по Краткому изображению процессов 1716 г. Петра I также оставался отводом весьма публичного свойства. Это было обусловлено тем, что военное устройство государства при Петре I предусматривало суд из 13 офицеров высшего состава во главе с генералом войска. Соответственно, отвод домжен был быть мотивированным. Заявленный одному из офицеров отвод рассматривался в отсутствие тяжущегося и отводимого офицера. При положительном рассмотрении отвода офицер подмежал замене другим офицером, при отказе в удовцетворении отвода тяжущегося наказывали [Нефедьев, Е. А., 1885, с. 94-95]. В эпоху Воинского устава самоотводы не применялись. Однако позднее, с введением повсеместно коцмегиального состава дия гражданских дец, самоотвод бым восстановцен (по реформе о судопроизводстве 1723 г.) [Нефедьев, Е. А., 1885, с. 96-97]. Однако уже в 1724 г. было велено, чтобы судья сам не устранялся даже при наличии оснований дмя отвода, но ждал отвода истца или ответчика. В то же время, поскольку Указ от 1723 г. не бым отменен, принято было, что судья сам не устранялся, но, если знал о причинах отвода, должен был сообщить об этом в присутствие [Нефедьев, Е. А., 1885, с. 99]. Указанные правила позднее вошии в состав Свода законов гражданских 1832 г. [Нефедьев, Е. А., 1885, с. 100].

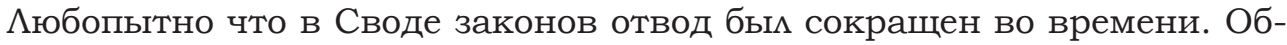
ращение с отводом стало возможным только до начала производства по дему [Нефедьев, Е. А., 1885, с. 100-101]. Это сокращение во времени было вполне могичным, поскоцьку заявцение отвода в момент, предшествующий моменту вынесения решения суда, как было раньше, аннулировало всю судебную деятельность суда, продеманную к этому моменту, т. е. аннулировалось все произведенное судебное разбирательство. Здесь мы не можем не отметить сходство ограничения отвода во времени по Своду законов с ограничением отвода во времени в Риме (до litis contestatio).

Самоотвод по Своду законов быц допустим при обращении отводимого к остальным членам суда со ссылкой на неспособность рассматривать дело, последние в свою очередь решали, удовлетворять такой отвод или нет. 


\section{Период действия Устава гражданского судопроизводства 1864 2.}

По Уставу гражданского судопроизводства (УГС) 1864 г. ограничение отвода во времени было сохранено. Устранение судьи тяжущимися в окружном суде допускалось не позднее первого заседания, "разве бы причина к устранению возникла впоследствии, в течение производства" (ст. 669 УГС $\left.{ }^{1}\right)$. Просьба об устранении мирового судьи истцом домжна быма быть заявлена вместе с иском, а ответчиком - не позднее первой явки на суд (ст. 196 УГС²).

Допускались самоотвод и мирового и окружного судьи, а также их от-

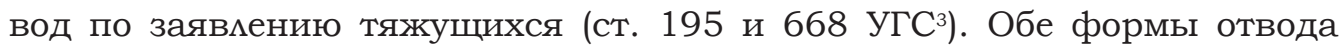
должны быми быть мотивированными. Мотивы дмя обоих форм отвода были определены в законе: наличие тяжбы между судьей и одним из тяжущихся, родственная связь или имущественная зависимость их друг от друга (ст. 195, 667 УГС $)$.

Как и другие институты процессуального права в России второй по-

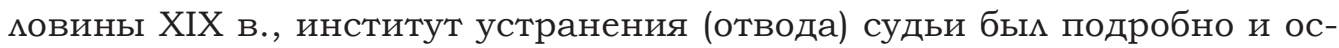
новательно урегулирован. Процедура отвода окружного судьи была следующей: отвод заявлялся тяжущимся отводимому судье, который не позднее следующего заседания обязан был тяжущемуся дать отзыв на этот отвод; замедление с отзывом было допустимо при условии согласия судьи с отводом, в противном случае отзыв судьи, возражавшего против отвода, рассматривался судом без участия отводимого судьи, по выслушивании заключения прокурора, в закрытом заседании; опредемение суда об устранении судьи обжалованию не подмежало, напротив, отказ в устранении судьи мог быть обжалован в трехдневный срок в суд, постановивший опредемение; эта жалоба должна была быть немедменно отсыцаема в высший суд; до рассмотрения высшим судом жалобы отводимый судья не мог принимать участия в рассмотрении дела; если отвод заявлялся нескольким судьям и оставшихся судей не хватамо для постановмения определения об отводе, то производство по дему останавливалось и заявцение об отводе вместе с отзывами отводимых судей передавались на рассмотрение высшего суда; положительный результат отвода судьи приводиц к тому, что высший суд дмя пополнения числа судей назначал судебных следователей ими почетных мировых

1 Судебные уставы 20 ноября 1864 года, с изможением рассуждений, на коих они основаны. Издание Государственной канцелярии. Часть первая. СПб. : Тип. Второго Отдемения Собственной Е. И. В. Канцемярии, 1866. С. 313.

2 Там же. С. 101.

3 Там же. С. 100-101, 313.

4 Там же. 
судей или же передавал демо в другой суд равной степени (ст. 671-678 УГС $\left.{ }^{5}\right)$.

Процедура отвода мирового судьи была следующей: отвод заявцялся истцом или ответчиком до первого судебного заседания; признав отвод основательным, мировой судья отстранялся от рассмотрения иска и передавал его со всеми материалами другому запасному мировому судье; если мировой судья не соглашался с отводом, то он не позднее двух дней с момента подачи требования об отводе передавал требование вместе со своими объяснениями на рассмотрение в мировой съезд (ст. 196-198 УГС ${ }^{6}$; отвод об устранении членов мирового съезда предъявлялся председателю съезда до открытия заседания по делу и разрешался мировым съездом без участия отводимого судьи после выслушивания прокурора (ст. 199 УГС $)$.

Дия сравнения приведем пример алгоритма устранения судьи по французскому праву XIX в. Отвод подавался секретарю, который передавал его председателю в течение 24 часов. Далее отвод слушался в судебном заседании при участии прокурора, который давал заключение. Предметом этого заседания был не сам отвод, но проверка допустимости или недопустимости отвода по закону; соответственно, обстоятельства, на которые указывал тяжущийся как на причину отвода, оставались пока незатронутыми. Заседание это проходимо в отсутствие тяжущихся и отводимого судьи, более того, пока не было получено положительного определения о допустимости отвода по закону, отводимый судья не доцжен быц знать об отводе. Однако после признания отвода допустимым отводимого судью информировали об отводе, и он должен был дать отзыв относительно отвода. В таком случае движение по делу приостанавмивалось. Если судья давал положительный отзыв на отвод, признавал его обоснованным, только на этом основании выносилось определение об отводе судьи. Если же судья отрицал факты, на которых основывал отвод тяжущийся, то последний должен был доказать их основательность в суде.

Если обоснованность отвода не была доказана, то отводимый судья продолжал рассматривать дело, а тяжущийся подвергался штрафу. Штрафу тяжущийся подвергался и в случае, если отвод был признан недопустимым, а также в случае пропуска срока, установценного дмя отвода. Более того, если основания отвода касались чести отводимого судьи, то он мог взыскать с тяжущегося убытки. Однако в последнем случае судья терял право продолжать ведение дема, по которому быц заявлен от-

5 Судебные уставы 20 ноября 1864 года, с изможением рассуждений, на коих они основаны. С. 313-314.

6 Там же. С. 101.

7 Там же. С. 101. 
вод, поскоцьку, заявцяя иск об убытках, судья становицся противником тяжущемуся ${ }^{8}$.

Следует отметить одну особенность, на которую указал Е. А. Нефедьев. Французское производство по устранению судьи разрешалось без состязания сторон, поскольку спор здесь был не между сторонами, а между тяжущимся, предъявившим отвод, и отводимым судьей ${ }^{9}$ Эта особенность являлась веской причиной, по которой второй тяжущийся, противник заявителя отвода, не получал состязательных бумаг по заседанию об устранении судьи и даже не извещался о самом заседании по отводу судьи.

В этой особенности обращает на себя внимание то, что спор об отводе - это спор между заявителем отвода и отводимым судьей. Следовательно, возникает резонный вопрос: в случае отказа в удовлетворении заяв-

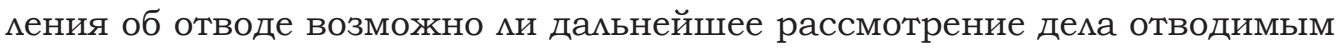
судьей? Если демо рассматривалось между тяжущимся, заявившим отвод, и отводимым судьей, то этот судья становился как бы противником тяжущегося, заявившего отвод, при рассмотрении заявцения об отводе.

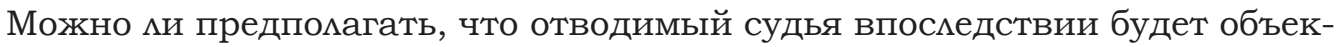
тивен к делу с участием этого тяжущегося - противника?

Конечно, эта ситуация разитемьно отличается от ситуации, когда отводимый судья предъявцяет иск о взыскании убытков, связанных с честью отводимого судьи. Здесь отводимый судья не перестает быть противником тяжущемуся в период возобновления рассмотрения дема по существу. Однако тот факт, что в период рассмотрения основного дела судья, рассматривающий его, становится одному из тяжущихся противником по делу об отводе, может поколебать беспристрастность при участии такого судьи в рассмотрении основного дема. Подозрение такого судьи в пристрастии (вражде) к тяжущемуся, заявившему ранее отвод, т. е. к бывшему противнику, не исключается. Следовательно, эта вражда может вылиться в отрицательное решение для тяжущегося, заявившего ранее отвод. Устранение такого судьи от дема вряд $\Lambda и$ бымо бы здесь целесообразным и справедливым, ведь в отводе судьи тяжущемуся было отказано. В то же время если признать, что объективность в таком случае все же может быть поколеблена, то, пожалуй, выходом могмо бы быть добавление еще одного судьи (conjudex), как в римском праве, и продолжение рассмотрения в дальнейшем дела ими совместно. Так или иначе, французское производство по рассмотрению вопроса об устранении судьи дает образец отвода судьи. Видно, что французское законодательство регулировало отвод судьи более подробно, чем российский Устав гражданского судопроизводства.

8 Судебные уставы 20 ноября 1864 года, с изложением рассуждений, на коих они основаны. С. 54-56.

9 Там же. С. 56. 


\section{Советский период}

В Положении о Народном Суде РСФСР 1920 г. вопросам отвода были посвящены ст. 50-52, 58 ${ }^{10}$. Эти нормы дают представцение об устранении судьи в ранний советский период. Отвод можно было заявить мюбому члену комлегии суда, т. е. и народному судье, и народному заседателю (ст. 50). Рассмотрение происходимо в отсутствие чцена суда, которому был заявлен отвод (абз. 2 ст. 51), на место которого привлекался запасной заседатель (абз. 1 ст. 51). Время подачи отвода было ограничено, отвод должен был быть заявлен при открытии судебного заседания (абз. 1 ст. 51). Здесь же председательствующий должен был специально разъяснить сторонам их право заявить отвод чиенам суда (ст. 58). Член суда подлежал самоотводу, если бым "прямо или косвенно заинтересован в исходе дела или находимся в родстве, или особых отношениях к сторонам" (ст. 52). По этим же основаниям отводимся судья сторонами.

В этом Положении ничего не говорится о положительном результате отвода. Можно предположить, что в таком случае дело подлежало рассмотрению с участием запасного заседателя или судьи. Также не обнаруживается указаний на ответственность заявителя отвода в случае признания отвода неосновательным.

В Гражданском процессуальном кодексе РСФСР (ГПК РСФСР) 1923 г. ${ }^{11}$ статей, посвященных отводу, было предусмотрено еще меньше, чем в Поможении о Народном Суде РСФСР. А^горитм отвода по первому советскому ГПК РСФСР 1923 г. быц следующим: как и по Положению, отвод можно бымо заявить и судье, и народному заседателю (ст. 104); время подачи отвода бымо ограничено, отвод домжен был быть заявлен "до начала разбора дела по существу" (ст. 102); мотивацией для отвода были: заинтересованность чиена суда в исходе дема и особые отношения с тяжущимся (ст. 104); по этим основаниям чмен суда мог быть отведен сторонами мибо должен был устраниться сам; в отличие от Положения о Народном Суде, в ГПК РСФСР 1923 г. нет указаний на необходимость устранения отводимого чиена суда при рассмотрении отвода; указание на то, что председательствующий должен разъяснить право об отводе при открытии заседания, в ГПК РСФСР 1923 г. также отсутствует. С другой стороны, в отличие от Положения о Народном Суде, в ГПК РСФСР 1923 г. указано на последствия положительного рассмотрения отвода; при удовцетворении отвода отводимый член суда заменялся другим; если по устранении народного

10 Декрет ВЦИК от 21 октября 1920 г. «Положение о Народном Суде Российской Социалистической Федеративной Советской Республики". Доступ из справочной правовой системы “КонсуцьтантПцюс".

11 Постановление ВЦИК от 10 июля 1923 г. "О введении в действие Гражданского Процессуального Кодекса Р.С.Ф.С.Р." (вместе с "Гражданским Процессуальным Кодексом Р.С.Ф.С.Р.»). Доступ из справочной правовой системы "КонсуцьтантПАюс". 
судьи замена его в этом суде была затруднительной, то демо подмежало передаче в другой суд (ст. 103); как и в Поможении, в ГПК РСФСР 1923 г. отсутствуют указания на ответственность заявителя отвода в случае признания отвода неосновательным.

Значительно более подробная регламентация устранения судьи в советском гражданском процессе была сформулирована в ГПК РСФСР 1964 г. $^{12}$

Как и ранее, отводу подмежали и судья, и народный заседатель. Отвод бым так же ограничен во времени: он доцжен быц заявляться до начала рассмотрения дема по существу. Председательствующий домжен был разъяснить мицам, участвующим в деме, их право заявлять отводы при открытии судебного заседания (ст. 154). Однако впервые ограничение на подачу отвода во времени подверглось оговорке - законодатель допустиц заявцение отвода позднее в случаях, когда основание дмя него сдемалось

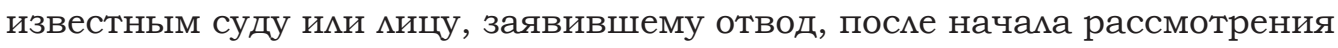
дела (абз. 2 ст. 22). Как и ранее, законодатель сформулировал общие основания дмя признания судьи пристрастным. Судья и народный заседатель подмежали отводу, если они мично прямо или косвенно были заинтересованы в исходе дела или имелись иные обстоятельства, вызывающие сомнение в их беспристрастности (ст. 17, п. 3 ст. 18). В то же время, в отАичие от ГПК РСФСР 1923 г., в новом ГПК РСФСР 1964 г. законодатель указал, что обыкновенного подозрения в беспристрастности судьи уже недостаточно, отвод домжен быть мотивированным (абз. 2 ст. 22). К уже указанным общим основаниям подозрения судьи (ст. 17) были добавмены еще три конкретных мотива дия отвода: во-первых, член суда подмежал отводу, если он при предыдущем рассмотрении дела участвовал в нем в качестве свидетеля, эксперта, переводчика, представителя, прокурора, секретаря судебного заседания (п. 1 ст. 18); во-вторых, он подлежал отво-

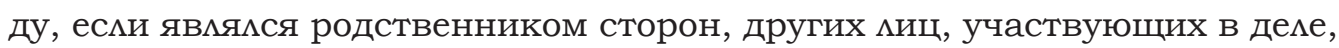
ими представителей, а также родственником другому члену суда (п. 2 абз. 1 и абз. 2 ст. 18); в-третьих, член суда подлежал отводу, если он уже принимал участие в рассмотрении этого дема в качестве судьи в иной инстанции (ст. 19). По этим основаниям чиен суда подмежац отводу со сто-

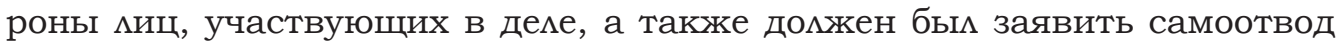
(абз. 1 ст. 22). Субъектный состав заявителей отвода в новом ГПК РСФСР 1964 г. был расширен: ранее отвод могли заявлять только стороны, теперь

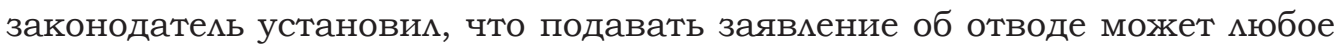
мицо, участвующее в деме.

Впервые бым подробно изложен порядок разрешения заявленного от-

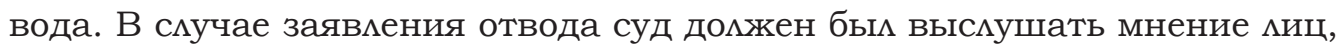
участвующих в деме, а также заслушать отводимого судью, если последний желал дать объяснения. Вопрос об отводе судьи разрешался осталь-

12 ГПК РСФСР (утв. Верховным Советом РСФСР 11 июня 1964 г.). Доступ из справочной правовой системы "КонсультантПлюс". 
ными судьями в отсутствие отводимого судьи. При равном количестве голосов, поданных за отвод и против отвода, судья считался отведенным. Вопрос об отводе разрешался в совещательной комнате. Отвод, заявценный нескольким судьям или всему составу суда, разрешался этим же судом в полном составе простым большинством голосов (ст. 23).

Впервые были подробно сформулированы последствия положительного рассмотрения отвода.

1. В случае отвода члена суда или всего состава суда при рассмотрении дела в районном (городском) народном суде дело рассматривалось в том же суде, но в ином составе судей. Демо подмежало передаче на рассмотрение в другой районный (городской) народный суд, если в районном (городском) народном суде, где рассматривалось демо, замена судьи оказалась невозможной.

2. В случае отвода члена суда или всего состава суда при рассмотрении дела в Верховном Суде РСФСР, Верховном суде автономной республики, краевом, областном, городском суде, суде автономной области и суде национального округа демо рассматривалось в том же суде, но в другом составе судей.

3. Дело домжно бымо быть передано в Верховный Суд РСФСР, если в Верховном суде автономной респубцики, краевом, областном, городском суде, суде автономной области и суде национального округа после удовметворения отводов было невозможно образовать новый состав судей дия рассмотрения данного дема (ст. 24).

Как видно, в ГПК РСФСР 1964 г. советский институт отвода судьи был сформулирован наиболее полно. Данное обстоятельство позволяет сравнить дореволюционный отвод с советским отводом и указать основные отмичитемьные черты последнего.

Во-первых, как и до революции, в советском ГПК РСФСР 1964 г. были сформулированы конкретные мотивы дмя отвода. Однако эти мотивы отмичались от тех, которые были изложены в УГС 1864 г. Основаниями дия отвода по УГС были: 1) наличие тяжбы между судьей и одним из тяжущихся, 2) их родственная связь, 3) их имущественная зависимость друг от друга. Основанием для отвода по ГПК РСФСР 1964 г. были: 1) участие судьи ранее в деле в том или ином качестве (прокурор, эксперт, свидетель мибо судья в другой инстанции по этому же дему и др.); 2) родственная связь с мицом, участвующим в деле, или с другим членом суда; 3) заинтересованность в исходе дема или иные обстоятельства, вызывающие сомнения в беспристрастности судьи.

Таким образом, в советское время в качестве мотива для отвода не

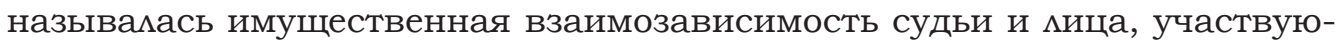
щего в деле, однако этот мотив косвенно вытекал из формулировки «заинтересованность в исходе дема" (ст. 17 ГПК РСФСР 1964 г.). В советский период для отвода также не называлось такое основание - наличие тяжбы между судьей и мицом, участвующим в деме. Однако и этот мотив 
можно было вывести из формулировки ГПК РСФСР 1964 г. - «иные обстоятельства, вызывающие сомнения в беспристрастности судьи" (ст. 17 ГПК РСФСР 1964 г.). Наличие родственных связей между судьей и тяжущимся, пожалуй, явцяется тем мотивом, в котором УГС 1864 г. и ГПК РСФСР 1964 г. принципиально не расходятся.

Несмотря на разцичные формулировки мотивов в ГПК РСФСР 1964 г. и в УГС, мы можем видеть, что все те основания дмя отвода, которые конкретно названы в УГС, в более расширительных формулировках излагаются в ГПК РСФСР 1964 г. Отсутствие широких формулировок в УГС комментаторы объясняли тем, что такие общие формулировки мотивов могли повлечь змоупотребления и волокиту дец со стороны тяжущихся ${ }^{13}$. В этой связи доревоцюционному законодателю пришиось достаточно конкретно формулировать мотивы дмя отвода в УГС. Как видно, советский законодатель пошем другим путем и предусмотрем в ГПК РСФСР 1964 г. широкое толкование мотивов к отводу, по-видимому, не опасаясь змоупотреблений

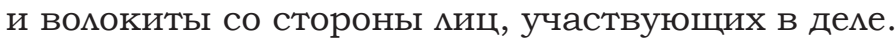

Во-вторых, отмичительной чертой правиц отвода, изложенных в ГПК РСФСР 1964 г., была возможность заявить отвод после открытия судебного заседания в случаях, когда основание для отвода сделалось известным суду ими мицу, участвующему в деме, после начала рассмотрения дела. Правила УГС в подобном случае разрешали отвод не позднее первого заседания, даже если бы причина отвода возникла впоследствии, в ходе производства по дему.

Относительно ограничения времени для отвода, изцоженного в УГС, Е. А. Нефедьев высказывался весьма критично. Укажем его замечания по этому поводу.

В зависимости от оснований отвода Е. А. Нефедъев подразделил судей на: 1) абсолютно неспособных, т. е. таких судъей, которые вообие не могли претендовать на должность судьи или членство в коллегиальном составе, например недееспособные судьи или судьи - родственники членов коллегии; 2) относительно неспособных, m. е. таких судъей, неспособность участия которых в деле определена в законе: наличие тяжбы между судьей и тяжушимся; родственная связь или имушественная зависимость ux друг от друга (ст. 667 УГС); 3) подозрительных судей, m. е. судей, подозрения на участие которых в деле прямо не предусмотрены в законе, однако эти подозрения вытекают из тех или иных соображений тяжуиихся. Абсолютная способность судьи проверялась при вступлении в должность, требования к ней были определены в судоустроительных нормах (Уиреждение судебных установлений), либо эта способность проверялась председателем коллегиального состава при его формировании, дабы исключить родственников в составе. Относительная способность судьи бъила строго опре-

13 Судебные уставы 20 ноября 1864 года, с изможением рассуждений, на коих они основаны. С. 313. 
делена в проиессуальном акте (cm. 667 УГС). Следовательно, рассмотрение дела абсолютно неспособньим или относительно неспособньм судъей приводило к ничтожности решения. Абсолютная и относительная способности судьи составляли одно из предположений проиесса. Устранение абсолютно неспособного и относительно неспособного судей совершалось в интересах государства, в публичном интересе. Иначе дело обстояло с подозрительньим судьей: основания для подозрения не указывались конкретно в законе, но содержались в обиих формулировках: "заинтересован в исходе дела", "иные обстоятельства, вызываюшие сомнение в беспристрастности судьи" u m. n. Соответственно, эти подозрения могли возникнуть у тяжушихся, и они были заинтересованы в том, итобы их заявить и отвести подозрительного судью. Тем самьим устранение подозрительного судьи совериалось по просъбе и в интересах тяжушихся [Нефедъев, Е. А., 1885, с. 7-8, 14, 30]. В отличие от франиузского проиессуального законодательства и законодательства древней Руси, УГС 1864 г. не предусматривал основания для отвода подозрительного судьи.

Указанные замечания Е. А. Нефедьева имеют существенное значение дия определения момента ограничения отвода. Относительно неспособный судья подиежал отводу независимо от времени рассмотрения дела: ведь его неспособность строго определена законом. Способность такого судьи явцямась публичным предположением процесса, следовательно, отсутствие таковой миквидировало процесс. Такой судья домжен был отвестись сам, но если он этого своевременно не демал, на это ему домжен был указать тяжущийся, без ограничения во времени. Напротив, подозрительность судьи к делу домжна была быть сформулирована стороной до рассмотрения дела по существу, в противном случае тяжущийся мишался права заявлять об этом в дальнейшем и решение, состоявшееся под подозрением, хотя и не выявменным своевременно тяжущимся, не подлежало кассации.

Руководствуясь этими соображениями, Е. А. Нефедьев критически относицся к ограничению времени для отвода, установленному в УГС дия относительно неспособного судьи, т. е. по мотивам, строго определенным в законе (ст. 667 УГС). Право отвода такого относитецьно неспособного судьи домжно было быть предоставцено во всяком положении дема, участие такого судьи в разрешении дема составцяло повод к кассации, считал Е. А. Нефедьев [Нефедьев, Е. А., 1885, с. 128, 130, 132]. Несмотря на ограничения УГС в этом вопросе, Сенат допускал в своей практике пра-

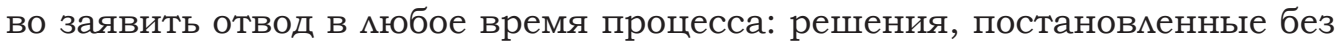
учета мотивов, изцоженных в законе (ст. 667 УГС), кассацией отменялись [Нефедьев, Е. А., 1885, с. 124-128].

Таким образом, дореволюционный законодатель не допускал позднейшее устранение относитемьно неспособного судьи, хотя домжен быц допускать это.

Исходя из указанных доводов, сформулированных по этому вопросу Е. А. Нефедьевым и поддержанных Сенатом, следует отметить, что со- 
ветский законодатель мог бы не допускать позднейшее устранение тех судей, которые "мично, прямо или косвенно были заинтересованы в исходе дела или имелись иные обстоятельства, вызывающие сомнение в их беспристрастности" (ст. 17), т. е. не допускать отвода подозрительных су-

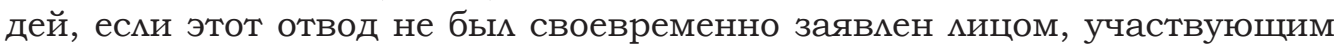
в деме. Напротив, абсолютно неспособные и относительно неспособные судьи домжны были подмежать отводу и в позднейшее время. Без ограничения во времени подлежали отводу судьи, которые: при предыдущем рассмотрении дела участвовали в нем в качестве свидетеля, эксперта, переводчика, представителя, прокурора, секретаря судебного заседания (п. 1 ст. 18); являлись родственниками сторон, других миц, участвующих в деме, или представителей, а также родственниками других членов суда (п. 2 и абз. 2 ст. 18); принимали участие в рассмотрении этого дема в качестве судьи в иной инстанции (ст. 19).

Таким образом, УГС не хватало оснований дмя признания судьи подозрительным. Дореволюционный законодатель здесь ограничился публичными основаниями дмя отвода относительно неспособного судьи во избежание волокиты. Напротив, советский законодатемь предусмотрец отвод и дмя подозритемьного, и дмя абсолютно неспособного, и дия относитемьно неспособного судьи, однако не отграничиц во времени отвод подозритецьных судей от отвода абсолютно и относительно неспособных судей. Подозрительный судья домжен был быть отведен мицом, участвующим в деме, до судебного заседания, не позже.

В-третьих, претерпец изменение порядок отвода одного судьи. До ревоцюции по заявценному отводу судья давал отзыв и далее отстранялся. Отвод рассматривался без участия отводимого судьи и тяжущихся, но с участием прокурора в закрытом заседании.

Во французском дореволюционном порядке отвода также было закреплено участие прокурора, но второй тяжущийся, не заявитель отвода, не привлекался в заседание, посвященное отводу. Причиной тому было признание того, что заседание об отводе - это спор тяжущегося, заявитемя отвода, и отводимого судьи. Боцее того, непризнание отводимым судьей заявценного отвода вцекло обязанность доказывания тяжущимся основатецьности заявленного им отвода в заседании об отводе.

По правилам советского ГПК РСФСР 1964 г. судебное заседание об от-

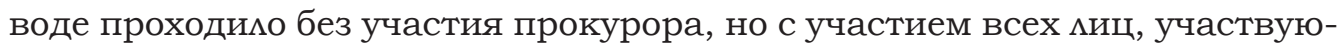
щих в деле, которых домжен был выслушать суд; заслушивался также отводимый чмен суда, если он желал дать по отводу свои объяснения.

Таким образом, в дореволюционном отводе одного судьи тяжущиеся и отводимый судья не участвовали, но участвовал прокурор. Во французском отводе одного судьи тяжущийся, не заявцявший отвода, не участвовал, но участвовали отводимый судья и тяжущийся, заявивший отвод, а также прокурор. Наконец, в советской модели отвода одного судьи

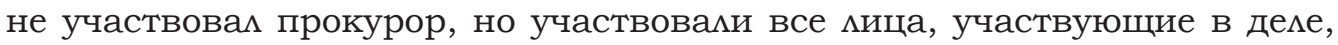


а также отводимый судья. Из изложенного следует, что в отличие от советского отвода в отводе российском и французском участвовал прокурор. Представцяется, что участие прокурора в рассмотрении отвода способствовало объективности этого процесса. Однако трудно вменить советскому отводу это в упрек, учитывая, что, в отмичие от российского и французского отвода, в советском процессе, в том числе и в вопросах отвода, всегда участвовали два народных заседатемя с правами профессиональных судей в полном объеме.

В-четвертых, претерпел изменение и порядок отвода нескольких судей. По правилам УГС 1864 г. если отвод заявлялся нескольким судьям и оставшихся судей не хватало дмя постановцения опредецения об отводе, то производство по дему останавцивалось и заявцение об отводе вместе с отзывами отводимых судей передавались на рассмотрение высшего суда (ст. 677 УГС). Напротив, по правимам ГПК РСФСР 1964 г. отвод, заявценный нескольким судьям или всему составу суда, разрешался этим же судом в полном составе простым большинством голосов (абз. 3 ст. 23 ГПК РСФСР 1964 г.).

Рассмотрение отвода тем же судом, которому заявцен отвод, соответствует правилам отвода времен Рима императорского периода. Магистрат сам рассматривац отводы на себя. Российское правицо здесь выглядит более частным, состязательным. Особенно в сравнении: во французской модеми отвод был состязанием тяжущегося, заявившего отвод, и отводимого судьи. Принимая во внимание французскую модець, правимо, позвоцяющее рассматривать отвод одним из тяжущихся, представцяется сомнительным.

В-пятых, французскими правилами отвода был предусмотрен штраф за отвод. Российскими правилами отвода штраф не был предусмотрен, но в проекте УГС статья о штрафе все же была. В УГС эту статью не включили потому, что отказ от всякого рода судебных штрафов был признан основным положением судебного преобразования ${ }^{14}$. В советской модеми устранения судьи для заявителя отвода, которому было отказано в отводе, штраф также не быц предусмотрен.

\section{Современный период}

В 1992 году законодатемем было принято решение о расширении полномочий судей по единоличному рассмотрению гражданских де ${ }^{15}$. Статья 15 ГПК РСФСР 1964 г., предписывавшая рассмотрение всех гражданских дел

14 Судебные уставы 20 ноября 1864 года, с изможением рассуждений, на коих они основаны. С. 314.

15 См.: Закон Российской Федерации от 29 мая 1992 г. № 2869-1 «О внесении изменений и дополнений в Закон РСФСР “О судоустройстве РСФСР”, Уголовно-процессуальный и Гражданский процессуальный кодексы РСФСР» (преамбула). Доступ из справочной правовой системы «КонсультантПцюс».

Правосудие/Justice. Т. 3, № 1. 2021. Оригинальные статьи 
с участием народных заседателей, была исключена ${ }^{16}$. Как следствие этого в правилах об отводе появицось новое положение об отводе единоличного судьи: отвод, заявленный судье, рассматривавшему дело единолично, разрешался тем же судьей (абз. 4 ст. 23 ГПК РСФСР 1964 г. в ред. Закона Российской Федерации от 29 мая 1992 г. № 2869-1). Это новое положение (абз. 4 ст. 23 ГПК РСФСР 1964 г.) практически повторяло старое положение абз. 3 ст. 23 ГПК РСФСР 1964 г., которое сходным образом решало вопрос об отводе всего состава колмегиального суда. Как и в случае с единоличным судьей, отвод, заявленный всему составу колмегиального суда, подмежал рассмотрению этим же судом. Поэтому следует здесь отметить определенную последовательность в могике законодателя, принявшего новое положение об отводе единоличного судьи. Необходимо опять упомянуть о сходном поможении УГС 1864 г. об отводе единоличного мирового судьи. По правилам УГС отвод, предъявленный единоличному мировому судье, подлежал рассмотрению высшим судом, т. е. мировым съездом (ст. 198 УГС).

С принятием Гражданского процессуального кодекса Российской Федерации 2002 г. (ГПК РФ) ${ }^{17}$ народные заседатели были отменены. Рассмотрение дел в судах первой инстанции судьями единолично стало общим правилом, что немногим изменило институт отвода судей в новом ГПК РФ. Повсеместно в нормах об отводе были скорректированы наименования судей, подмежащих отводу. Если в советский период это были судьи и народные заседатели, то теперь это стали единоличные мировой и федеральный судья. В остальном же в первый период действия ГПК РФ 2002 г., отвод оставался прежним, сформированным еще в ГПК РСФСР 1964 г. Поэтому мы не будем раскрывать алгоритм отвода судей по правилам ГПК РФ 2002 г., а сразу приступим к описанию тех немногих изменений, которые последовали в ГПК РФ 2002 г. после его принятия и действуют вплоть до настоящего времени.

Во-первых, пополнился перечень оснований дмя признания судьи относительно неспособным: с 2019 г. отводу подмежит мировой судья или судья, который являлся судебным примирителем по данному делу (п. 1.1 ч. 1 ст. 16 ГПК РФ 2002 г.). Кроме того, уточнено, что автоматическому признанию подозрительным не подлежит судья, который получиц внепроцессуальное обращение по гражданскому делу, находящемуся в его производстве (ч. 3 ст. 16 ГПК РФ 2002 г.).

Сцедует отметить, что оба эти изменения являются скорее отражением судебной реформы в целом, нежели изменениями, конкретно ориентиро-

16 См.: Закон Российской Федерации от 29 мая 1992 г. № 2869-1 «О внесении изменений и дополнений в Закон РСФСР “О судоустройстве РСФСР”, Уголовно-процессуальный и Гражданский процессуальный кодексы РСФСР» (п. 3). Доступ из справочной правовой системы «КонсультантПцюс».

17 Гражданский процессуальный кодекс Российской Федерации от 14 ноября 2002 г. № 138-ФЗ. Доступ из справочной правовой системы «КонсультантПАюс». 
ванными на институт отвода судьи. Первое изменение явцяется резуцьтатом развития института примирения в гражданском процессе, второе изменение связано с укреплением принципа независимости судьей.

Во-вторых, в отличие от УГС, в ГПК РФ 2002 г. сохранилось положение ГПК РСФСР 1964 г., согласно которому подозритемьный судья подмежит отводу наравне с абсолютно и относительно неспособным судьей (ст. 17 ГПК РСФСР 1964 г. и п. 1 ч. 3 ст. 16 ГПК РФ 2002 г.). Также сохраницось правицо о времени отвода. И подозрительный, и абсолютно и относительно неспособные судьи подиежали отводу в одно и то же время, т. е. вплоть до вынесения решения. Выше мы указывали, что подозрительный судья домжен бым быть отведен мицом, участвующим в деме, до начала судебного разбирательства, не позже. Однако вслед за ГПК РСФСР 1964 г. это правило сохранилось без корректив и в новом ГПК РФ 2002 г. Отсутствие права на отвод подозрительного судьи в дореволюционном процессе объяснялось тем, что наличие основания дия признания подозрительным судьи могмо привести к «...заявмению бесконечных и самых неосновательных притязаний, служащих к напрасному обременению судебных мест, а иногда и к самому замедмению дема" [Нефедьев, Е. А., 1885, с. 133]. Поэтому в ст. 667 УГС бым установлен конкретный список оснований дмя отвода, не подмежащий расширительному толкованию, т. е. список, указывающий на относительно неспособных судей, но не на подозрительных.

В советский период в условиях незначитемьной нагрузки судей по гражданским демам, а также при участии в отправлении правосудия народных заседателей законодатель не посчитал необходимым предусмо-

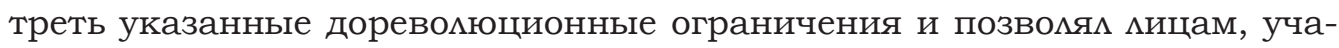
ствующим в деле, выходить за пределы списка оснований дмя отвода, служащих указанием на абсолютно и относительно неспособного судью. В этой связи возможность дмя признания судьи подозрительным, предусмотренную в ст. 17 ГПК РСФСР 1964 г., можно отнести к преимуществу ГПК перед УГС. Е. А. Нефедьев справедииво считал, что отсутствие в УГС этой возможности "...противоречило истории развития института устранения судей" [Нефедьев, Е. А., 1885, с. 133]. Однако на современном этапе развития этого института указанная возможность признания судьи подозрительным не могла долго сохраняться без каких- ибо ограничений. С развитием частной собственности нагрузка на гражданское судопроизводство кратно возросла. Возросло и количество злоупотреблений со сто-

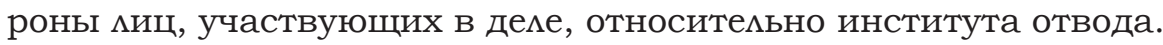

Поэтому в новое время институт отвода стал попоцняться дополнительными ограничениями, хотя право на отвод подозрительного судьи не бымо искцючено вовсе. Так, ст. 19 ГПК РФ 2002 г. пополнилась частью

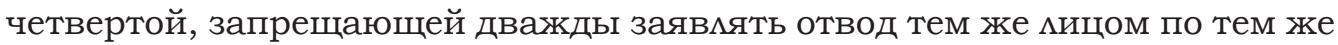
основаниям. Ограничению возможных змоупотреблений при заявлении

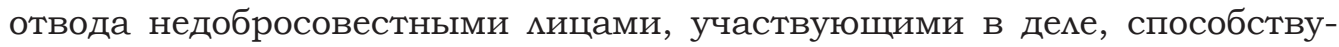
ет и правило об отводе, позволяющее рассмотрение отвода самим отво- 
димым судом (ч. 4 ст. 23 ГПК РСФСР 1964 г. и ч. 2 ст. 20 ГПК РФ 2002 г. (в ред. от 1 февраля 2003 г.). Подобных норм не было в дореволюционном институте устранения судей. Отвод не рассматривался отводимым судом. Это наследие советского ГПК РСФСР 1964 г. Современный ГПК РФ 2002 г. (в ред. от 28 ноября 2018 г. № 451-ФЗ пополнился правилом, способствующим еще более быстрой реакции единоличного судьи на недобросовест-

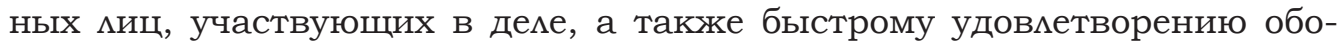
снованного заявцения об отводе единоличного судьи. По новому правилу судье больше не надо удаляться в совещательную комнату дмя вынесения опредемения по заявлению об отводе: теперь он может это сдемать не удамяясь в совещательную комнату, прямо на месте вынести протокоцьное опредемение об отводе (ч. 1 и 2 ст. 20 ГПК РФ). Это новое правицо указывает на то, что законодатель не признает состязательным алгоритмом рассмотрение отвода единоличным судьей. Рассмотрение отвода высшим судом, как это было до революции, выглядит более состязательным. В защиту рассмотрения отвода отводимым единоличным судом следует отметить, что, во-первых, заявитель отвода, которому было отказано в отводе, может впоследствии обжаловать этот отказ в проверочную инстанцию; во-вторых, это правицо имемо исторический опыт в Древнем Риме императорской эпохи и не выглядит здесь абсолютно новым.

\section{Обсуждение и закиючение}

Устранение судьи появицось в римском праве как проявцение частного начала (jus privatum): в период Республики устранением (recusatio) истец и ответчик выбирали себе частного судью дия разбора дема. С изменением политической обстановки в Риме изменилась и роль устранения судьи. В императорский период стали отстранять от разбора дела пристрастного государственного судью (магистрата). Тем самым выборная роль отвода была утрачена, устранение судьи стало выполнять роль пубцичного (jus publicum) механизма по отстранению государственного магистрата от разбора дема. Соответственно, изменению были подвергнуты конструктивные элементы, которые составляли механизм устранения судей в Древнем Риме (форма; мотивация; время; результат). Из формы избрания частного судьи устранение трансформировалось в форму отвода пристрастного государственного магистрата. Из немотивированного устранения частного судьи устранение превратилось в мотивированный отвод магистрата. В качестве результата отвода замена частного судьи сменимась присоединением к подозрительному магистрату еще одного неподозрительного магистрата. Один только конструктивный элемент римского устранения судьи остался без изменений, хотя он также домжен бы , по справедиивому замечанию Е. А. Нефедьева, претерпеть изменение: заявмение отвода только до litis contestatio в обоих римских периодах, однако в относительно поздний период сторонам было позволено заявить отвод и после litis contestatio. 
Развитие отвода на Руси и в России в период с Соборного уможения 1649 г. до Свода законов гражданских 1832 г. было весьма похоже на действие этого института в императорский период в Риме. Как и в Риме, на Руси отвод был явлением публичного свойства (jus publicum), о чем свидетельствуют его конструктивные элементы. Отвод был в форме отстранения пристрастного государственного чиновника, также бым мотивированным, ограниченным во времени, однако в отличие от римского отвода, срок подачи русского отвода был сдвинут - вплоть до вынесения решения. Самоотвод был допустим на Руси только для колмегиального состава - для Боярской Думы, единоличный самоотвод не допускался.

Отступлению от римских правиц отвода в России и их усложнению способствовало распространение в России комлегиального состава судопроизводства. Уже при Петре I были расширены правила об отводе ввиду рассмотрения гражданских дем в колмегиальном составе. Так, отводимый судья (офицер) отстранялся от рассмотрения отвода, и отвод рассматривался в его отсутствие остальными чценами суда (офицерами). Положительный результат отвода приводил к замене отводимого судьи другим судьей в составе коммегии. В то же время некоторые элементы российского отвода демонстрировали возврат к правилам римской эпохи. Так, в Своде законов гражданских 1832 г. время заявления отвода было сокращено до времени открытия судебного заседания, т. е. практически до римского litis contestatio.

Указанная тенденция в развитии российского института отвода сохранилась и после принятия Судебных уставов 1864 г. С одной стороны, имеет место усложнение отвода в УГС, с другой стороны, виден и возврат к римским правилам отвода времен Империи. В отличие от римского отвода магистрата единоличный мировой судья в России не рассматривал отвод на себя самого. Вопрос о его отводе передавался на рассмотрение мирового съезда. В случае положительного результата отвода единоличный мировой судья не был дополнен в процессе другим беспристрастным судьей, как это было в Риме. Напротив, пристрастного мирового судью просто заменяли другим. В то же время, как и в правилах римского отвода, УГС допустиц самоотвод единоличного мирового судьи.

Правила отстранения окружного судьи в УГС были сформулированы как в ситуации французского отвода. В случае несогласия с отводом отводимый судья давал отзыв на отвод и устранялся от рассмотрения дела. Далее отвод рассматривался остальными чиенами суда или высшим судом с участием прокурора. Однако французский отвод быц еще более детализирован, чем российский отвод. Весь алгоритм французского отвода был разделен на две части: 1) рассмотрение вопроса о допустимости отвода; 2) рассмотрение непосредственно отвода, при условии признания его допустимым в первой части. Российский УГС впитал только вторую часть процедуры французского отвода. 
Правила отстранения советского судьи начали формироваться уже в Поможении о Народном Суде РСФСР 1920 г., а затем в ГПК РСФСР 1923 г. Однако наиболее полные и подробные правила об отводе были сформулированы в ГПК РСФСР 1964 г. Сравнение этих правиц с правилами УГС позволимо сформулировать основные отличительные черты советского отвода.

Во-первых, в отличие от УГС в ГПК РСФСР 1964 г. были предусмотре-

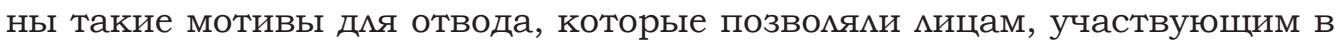
деле, признавать судью и абсолютно, и относительно неспособным и подозрительным. В могической связи с этим нововведением было положение, позволившее заинтересованным мицам заявить отвод и после начала рассмотрения дела по существу. Однако можно признать некорректным правило советского периода, согласно которому подозрительный судья наравне с абсолютно и относительно неспособным судьей подлежал отводу без ограничения во времени. История развития отвода в России и за рубежом показала, что отвод подозрительного судьи должен быть ограничен во времени, т. е. может быть заявлен мицом, участвующим в деле, только до начала судебного разбирательства.

Во-вторых, в процедуре дореволюционного отвода одного судьи не участвовали тяжущийся и отводимый судья, но участвовал прокурор. Во французском отводе одного судьи не принимал участия тяжущийся, не заявлявший отвода, но участвовали отводимый судья и тяжущийся, заявивший отвод, а также прокурор. Наконец, советская модель отвода одного судьи не предусматривала участия прокурора, но предполагала участие всех $и ц$, участвующих в деле, а также отводимого судьи. Как видно, в отличие от советского отвода в отводе российском и французском участвовал прокурор, причастность которого к рассмотрению отвода способствовала объективности этого процесса. Однако трудно вменить советскому отводу это в упрек, учитывая, что в отличие от российского и французского отвода в советском процессе, в том числе и в вопросах отвода, всегда участвовали два народных заседателя с правами профессиональных судьей в полном объеме.

В-третьих, в доревоцюционном отводе нескольких судей при нехватке оставшихся судей для постановцения определения об отводе заявление об отводе с отзывами отводимых судей передавалось на рассмотрение высшего суда. Напротив, отвод, заявленный нескольким судьям или всему составу советского суда, разрешался этим же судом в полном составе простым большинством голосов. Первый отвод в большей степени соответствовал частной французской состязательной модели, второй отвод публичной модели римского императорского отвода.

В-четвертых, в отличие от французской модели отвода российская и советская модели отвода не предусматривали штраф для заявителя отвода, которому в отводе бымо отказано.

Современный институт отвода судьи явцяется преемником советского, и ему присущи все указанные основные отличительные черты советского 
отвода. Состоявшиеся изменения отвода в новейшее время можно сгруппировать следующим образом. Во-первых, это изменения, связанные с судебной реформой: с введением в качестве основного единоличного состава рассмотрения дема; с усилением независимости судей и с расширением примирительных процедур. К новемлам относятся: 1) правило о рассмотрении единоличным судьей отвода на себя самого, а также механизм протокоцьной фиксации им результата этого отвода; 2) признание относительно неспособным судьи, который ранее участвовал в рассматриваемом деле в качестве судебного примирителя; 3) непризнание автоматически подозрительным судьи, который получим внепроцессуальное обращение по гражданскому делу, находящемуся в его производстве. Во-вторых, изменение отвода, которое является следствием допущения признания судьи подозрительным в $ю-~$ бое время судебного разбирательства, а также отсутствия ответственности для недобросовестных заявителей отвода. Это новое правило, запрещающее дважды заявлять отвод одним и тем же мицом по тем же основаниям.

Как видно, первая группа изменений в целом является результатом судебной реформы. Второе изменение представцяется попыткой современного законодателя скорректировать ошибку в правилах советского отвода, в которых был допущен отвод подозрительного судьи без ограничения во времени.

Дальнейшее существенное изменение правиц отвода на современном этапе возможно путем перехода к колмегиальному рассмотрению гражданских дел. В таком случае отвод может быть пересмотрен кардинально, в нем может быть усилено состязательное начало с учетом исторического опыта. Однако рассмотрение гражданских дем комлегиальным составом потребует увеличения продолжительности времени на судебное разбирательство. Высокая судебная нагрузка по гражданским демам пока не позволяет этого сделать, поэтому существенные изменения возможны в отдаленной перспективе или по ограниченным категориям наиболее важных дел, например по делам о Аишении родительских прав. Представмяется, что в ближайшей перспективе сохранится тенденция изменения отвода косвенным образом, т. е. под влиянием факторов судебной реформы. В качестве предупреждения заявления недобросовестных отводов уже в ближайшее время можно предложить следующие изменения: во-первых, ограничить во времени отводы подозрительных судей; вовторых, ввести штраф за неподтвержденный отвод.

\section{Список использованной иитературы}

Аргунов А. В. Особое производство в гражданском процессуальном праве России и Франции. М. : Проспект, 2013. 232 с.

Боголепов Н. П. Учебник истории римского права. М. : Зерцало, 2004. 568 c. 
Дмитриев Т. История судебных инстанций и гражданского апемяяционного судопроизводства от судебника до учреждения о губерниях. М. : Университетская тип., 1859. 580 с.

Кавелин К. Основные начала русского судоустройства и гражданского судопроизводства, в период времени от УАожения до Учреждения о губерниях. М. : Тип. Августа Семена, 1844. 186 с.

Муромцев С. А. Определение и основное разделение права // Избранные труды по римскому и гражданскому праву. М. : Центр ЮрИнфоР, 2004. 765 с. (Репринт издания 1879 г.)

Нефедьев Е. А. Устранение судей в гражданском процессе. Казань : Тип. Императорского Казан. ун-та, 1885. 170 с.

Покровский И. А. История римского права. СПб. : Изд.-торговый дом "Аетний сад", 1998. 560 с.

Хвостов В. М. История римского права. М. : Моск. науч. изд-во, 1919. 468 c.

\section{References}

Argunov, A. V., 2013. Osoboye proizvodstvo $v$ grazhdanskom protsessual'nom prave Rossii $i$ Frantsii = [Special proceedings in the civil procedure law of Russia and France]. Moscow: Prospect. (In Russ.)

Bogolepov, N. P., 2004. Uchebnik istorii rimskogo prava $=[$ Textbook of the history of Roman law]. Moscow: Zertsalo. (In Russ.)

Dmitriev, T., 1859. Istoriya sudebnykh instantsiy $i$ grazhdanskogo apellyatsionnogo sudoproizvodstva ot sudebnika do uchrezhdeniya o guberniyakh $=$ [The history of judicial instances and civil appellate proceedings from the sudebnik to the institution of the provinces]. Moscow: University's Publishing House. (In Russ.)

Kavelin, K., 1844. Osnovnyye nachala russkogo sudoustroystva $i$ grazhdanskogo sudoproizvodstva, $v$ period vremeni ot Ulozheniya do Uchrezhdeniya o guberniyakh $=[$ The main principles of the Russian judicial system and civil proceedings, in the period of time from the Code to the Institution of the provinces]. Moscow: Printing house of August Semyon. (In Russ.)

Muromtsev, S. A., 2004. [Definition and basic division of law]. Izbrannyye trudy po rimskomu i grazhdanskomu pravu = [Selected works on Roman and civil law]. Moscow: Center YurInfoR. (Reprint edition of 1879). (In Russ.)

Nefedyev, E. A., 1885. Ustraneniye sudey $v$ grazhdanskom protsesse $=$ [Elimination of judges in civil proceedings]. Kazan: Printing House of the Imperial Kazan University. (In Russ.)

Pokrovsky, I. A., 1998. Istoriya rimskogo prava = [History of Roman law]. St. Petersburg: Publishing and Trading House "Letniy sad". (In Russ.) 
Khvostov, V. M., 1919. Istoriya rimskogo prava = [History of Roman law]. Moscow: Moscow Scientific Publishing House. (In Russ.)

\section{Информация об авторе / Information about the author}

Поскребнев Максим Евгеньевич, кандидат юридических наук, доцент кафедры гражданского и административного судопроизводства ФГБОУВО “Российский государственный университет правосудия" (Российская Федерация, 117418, г. Москва, Новочеремушкинская ул., д. 69) Maxim E. Poskrebnev, Cand. Sci. (Law), Associate Professor of the Civil and Administrative Procedure Department, Russian State University of Justice (69 Novocheremushkinskaya St., Moscow, 117418, Russian Federation).

E-mail: forceline@mail.ru

Дата поступления рукописи в редакцию издания: 28.12.2020; дата одобрения после рецензирования: 25.01.2021; дата принятия статьи к опубликованию: 02.02.2021.

Submitted 28.12.2020; reviewed 25.01.2021; revised 02.02.2021. 


\title{
Признаки субъекта преступления, предусмотренного статьей 243.2 Уголовного кодекса Российской Федерации
}

\author{
И. А. Халиков \\ Казанский юридический институт (филиал) ФГКОУ ВО \\ «Университет прокуратуры Российской Федерации», г. Казань, \\ Российская Федерация \\ iskanderh@mail.ru
}

\begin{abstract}
Аннотация
Введение. Изучение отечественной истории, в особенности ее периода, характеризующегося отсутствием письменных источников информации, невозможно без обращения к результатам работы археологов. Вместе с тем научную ценность представляют только те археологические исследования, которые проведены на основании официального разрешения (открытого листа), обязывающего ученых предоставлять отчет о характере и объеме проведенных полевых работ, а также сведения о найденных артефрактах. Это отличает профессиональных археологов от любителей, которые «раскапывают» объекты археологического наследия, как правило, для удовлетворения собственного исследовательского интереса, пополнения частных коллекций древностей, а также извлечения прибыли от их реализации на теневом антикварном рынке. Своими действиями они совершают преступления в отношении культурного наследия, что порождает необходимость изучения признаков субъекта преступления, предусмотренного ст. 243.2 УК РФ, для наделения сотрудников правоохранительных органов эффрективным уголовно-правовым средством противодействия незаконной археологической деятельности.

Теоретические основы. Методы. Проведенное исследование основывается на общенаучных и специальных методах. В его теоретическую основу легли труды отечественных и зарубежных ученых в области уголовного права, криминологии, археологии, а также опыт работы государственных органов Российской Федерации и стран Европы по сохранению историко-культурного наследия.

Результаты исследования. Изучение правоприменительной практики и научной литературы показывает, что существуют проблемы отнесения к субъектам преступления, предусмотренного ст. 243.2 УК РФ, лиц, осуществляющих псевдоархеологические работы без официального разрешения. На основании результатов отечественных и зарубежных научных исследований делается вывод об обоснованности отнесения приборного поиска к отягчающим ответственность обстоятельствам.

Обсуждение и заключение. С учетом международного опыта противодействия незаконной археологической деятельности, анализа отечественной правоприменительной практики делается вывод о необходимости уточнения признаков субъекта преступления путем внесения изменений в диспозицию ч. 1 ст. 243.2 УК РФ.
\end{abstract}


Ключевые слова: субъект преступления, объект археологического наследия, археологический предмет, объекты культурного наследия, памятники истории и культуры

Для цитирования: Халиков И. А. Признаки субъекта преступления, предусмотренного статьей 243.2 Уголовного кодекса Российской Федерации // Правосудие/Justice. 2021. T. 3, № 1. C. 113-127. DOI: 10.37399/2686-9241.2021.1.113-127.

\title{
The Signs of the Subject of a Crime under Article 243.2 of the Criminal Code of the Russian Federation
}

\section{Iskander A. Khalikov}

\author{
Kazan Law Institute (Branch) of the University of Prosecutor's Office \\ of the Russian Federation, Kazan, Russian ederation \\ For correspondence: iskanderh@mail.ru
}

\begin{abstract}
Introduction. When studying history, the results of the work of archaeologists play a significant role. At the same time, for science, only those studies that are conducted by scientists on the basis of a state-issued permit (the so called open sheet) are of value. In accordance with the permit, scientists are required to provide reports on the excavations carried out and information about the objects found. This is what distinguishes professional archaeologists from nonprofessional history enthusiasts. Such enthusiasts dig atr archaeological sites because of their interest, to create private collections and to sell items of historical value in antique markets. By their actions, they commit crimes against cultural heritage. This makes it necessary to study the characteristics of the subject of the crime provided for in art. 243.2 of the Criminal code of the Russian Federation in order for criminal officers to properly deal with crimes in the field of archeology.

Theoretical Basis. Methods. The research is based on general scientific and special research methods. The theoretical base consists of the works of domestic and foreign scientists in the field of law, history, archaeology, as well as the experience of competent authorities in the field of cultural heritage preservation.

Results. The analysis of the work of the competent authorities and the study of legal literature led to the conclusion about the problems associated with the attribution to the subject of crime of persons searching for archaeological objects without obtaining a state permit.

Discussion and Conclusion. Taking into account the accumulated international experience of countering illegal archaeology, studying domestic law enforcement practice, it is concluded that it is necessary to clarify the characteristics of the subject of the crime by making changes to the disposition of part 1 of art. 243.2 of the Criminal code of the Russian Federation.
\end{abstract}

Keywords: subject of crime, object of archaeological heritage, archaeological object, objects of cultural heritage, historical and cultural monuments

For citation: Khalikov, I. A., 2021. The signs of the subject of a crime under article 243.2 of the Criminal code of the Russian Federation. Pravosudie/Justice, 3(2), pp. 113-127. DOI: 10.37399/2686-9241.2021.1.113-127.

\section{Введение}

Сохранение археологического наследия, его защита от грабительских раскопок признаны Правительством Российской Федерации одной из задач, требующих от органов исполнительной власти государства принятия должных мер правового характера. Это нашио отражение в Стратегии 
государственной культурной политики Российской Федерации на период до 2030 года ${ }^{1}$.

Одним из основных источников угрозы дия эмементов археологического наследия в последнее десятилетие стало проведение незаконных раскопок с целью пополнения частных комлекций, а также извлечения прибыли от сбыта археологических предметов. Объектами разграбления стали сарматские курганы юга России, средневековые поселения центрально-европейской ее части, античные города черноморского побережья. Апологеты незаконного поиска археологических предметов создами в сети «Интернет" большое количество "кладоискательских" сайтов, расширяющих их возможности при обмене информацией, кооперации при проведении нелегальных раскопок, а также сбыте артефактов, полученных противо-

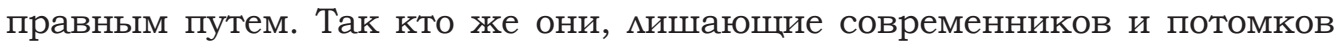
возможности расширить общедоступные знания о развитии истории чемовечества? Романтики, сравнивающие себя с Индианой Джонсом, или прагматики, создающие частные комлекции "древностей", получающие доход от продажи археологических предметов? В проводимом исследовании мы обратимся к наиболее характерным признакам субъекта преступцения, предусмотренного ст. 243.2 УК РФ «Незаконные поиск и (или) изъятие археологических предметов из мест залегания". Они имеют определяющее значение при отграничении преступления от административного правонарушения, отнесении содеянного к квалифицированному составу преступления, предусмотренному частью третьей этой же статьи уголовного закона.

Большинство исследований, посвященных проблеме раскрытия при-

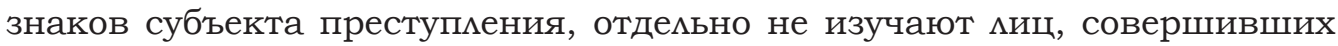
противоправные деяния в отношении археологического наследия. Общие аспекты научной проблемы освещены в работах $\Lambda$. Р. Клебанова [Клебанов, $\Lambda$. Р., 2012], А. А. Ковалева [Ковалев, А. А., 2015], Р. Б. Осокина [Осокин, Р. Б., 2014], А. Н. Панфимова [Панфимов, А. Н., 2017], Т. Р. Сабитова [Сабитов, Т. Р., 2016]. Существует целый ряд зарубежных уголовно-правовых и криминологических исследований, посвященных указанной проблематике [Brent, M., 1994; Brun, Y. and Triboulot, B., 2017; Karl, R., 2011; Thomas, S., 2013 и др.].

С учетом изцоженного целью проводимого исследования является рассмотрение существующих проблем, связанных с определением субъекта преступцения, предусмотренного ст. 243.2 УК РФ. Дия ее реализации предполагается решение следующих задач: провести анализ признаков субъекта преступления, а также сформулировать предможения по недопущению двойственности их толкования при квалификации совершенных преступлений.

1 Распоряжение Правительства Российской Федерации от 29 февраля 2016 г. № 326-р “Об утверждении Стратегии государственной культурной политики на период до 2030 года" // Собрание законодательства Российской Федерации. 2016. № 11. Ст. 1552. 


\section{Теоретические основы. Методы}

Исходя из характера и особенностей совершаемых в отношении археологического наследия правонарушений в работе использованы системный метод изучения субъекта преступления, а также общенаучные (статистические, прогностические и др.) и специальные методы исследования (формально-логический анализ, сравнительно-правовое исследование и др.). Теоретическую основу составили труды отечественных и зарубежных ученых в области уголовного права, криминологии, археологии, а также опыт работы государственных органов Российской Федерации и стран Европы по сохранению историко-культурного наследия.

\section{Резуцьтаты исследования}

В соответствии с общими правилами, предусмотренными ч. 1 ст. 20 УК РФ, уголовной ответственности за преступление, предусмотренное ст. 243.2 УК РФ, подмежит мицо, достигшее 16-летнего возраста. Приведенное поможение распространяется на субъекта преступцения, предусмотренного ч. 1, 2, а также п. "В" ч. 3 нормы уголовного закона.

Осуществляющие незаконный поиск считают, что субъект преступления в рассматриваемой норме уголовного закона - специальный: это археолог Аибо сотрудник государственного органа охраны объектов культурного наследия, проводящий археологические полевые работы (археологическую разведку, археологические раскопки, археологическое наблюдение) с нарушением установценных законом требований ${ }^{2}$. Приведенная позиция обусловлена желанием "черных археологов" уйти от уголовной ответственности за преступления в отношении археологического наследия. Она требует обсуждения с целью недопущения правоприменительных ошибок.

Статья уголовного закона сформулирована таким образом, чтобы исключить возможность конкуренции состава преступления с составом административного правонарушения, предусмотренного ст. 7.15 КоАП РФ «Проведение археологических полевых работ без разрешения». В соответствии со статьей КоАП РФ возможно привлечение к административной ответственности археологов, проводящих археологические полевые работы без полученного в установленном порядке разрешения мибо с нарушением условий, предусмотренных разрешением (открытым мистом). В проекте федерального закона о внесении изменений в отдельные законодательные акты Российской Федерации в части пресечения незаконной деятельности в обцасти археологии (быц принят ${ }^{3}$ ), внесенном на рассмотрение Государственной Думы Федерального Собрания Российской Федерации,

2 О "черной археологии", копателях и разрушении археологических памятников. Черные археологи. URL: https:/gameriskprofit.ru/prichyostki/o-ch-rnoi-arheologiikopatelyah-i-razrushenii-arheologicheskih/ (дата обращения: 02.11.2020).

3 Федеральный закон от 23 июля 2013 г. № 245-Ф3 “О внесении изменений в отдельные законодательные акты Российской Федерации в части пресечения неза- 
была предусмотрена уголовная ответственность за "ведение археологических полевых работ, вкцючая поднятие со дна водного объекта археологических предметов, без полученного в установценном порядке разрешения (открытого миста) мибо с нарушением условий, предусмотренных разрешением (открытым мистом), повцекшее повреждение ими уничтожение культурного слоя" ${ }^{4}$. Проект нормы уголовного закона и ст. 7.15 КоАП РФ были идентичны по своему содержанию. Это не способствовало достижению целей криминализации преступного поведения, поскольку вызывало затруднения разграничения норм, предусматривающих ответственность за правонарушения и преступления в отношении памятников археологии. Исходя из содержания проекта закона субъектом неквалифицированного вида преступления выступал профессиональный археолог: только он проводит полевые археологические работы (археологическую разведку, археологические раскопки, археологическое набцюдение). Работы по проведению незаконного поиска археологических предметов, т. е. преступление, предусмотренное ч. 1, 2 ст. 243.2 УК РФ, нельзя отнести к числу полевых археологических, поскольку они изначально явцяются незаконнъии.

Полевые археологические работы, проводимые на основании выданного специального разрешения (открытого миста), - это единственный $\Lambda е-$ гальный источник обнаружения и изъятия представцяющих археологическую ценность предметов. Извцечение из культурного слоя археологических предметов без соответствующего разрешения (открытого миста) средствами и способами, не указанными в ст. 45.1 Федерального закона от 25 июня 2002 г. № 73-Ф3 «Об объектах культурного наследия (памятниках истории и культуры) народов Российской Федерации" ${ }^{5}$ (далее - Федеральный закон № 73-Ф3), явцяется незаконным.

Действующая редакция ст. 243.2 УК РФ предусматривает уголовную ответственность за "поиск и (ими) изъятие археологических предметов из мест залегания на поверхности земли, в земле или под водой, проводимые без разрешения (открытого листа) (курсив наш. - И. Х.), повцекшие повреждение или уничтожение культурного слоя". Дия искАючения двойственности толкования содержания ч. 1 ст. 243.2 УК РФ следует иметь в виду, что действия, составцяющие объективную сторону состава преступцения, изначально отнесены законодателем к числу незаконных. Таким образом, является изАишним указание в диспозиции части первой

конной деятельности в области археологии" // Собрание законодательства Российской Федерации. 2013. № 30 (ч. І). Ст. 4078.

4 Законопроект № 217902-6 «О внесении изменений в отдельные законодательные акты Российской Федерации в части пресечения незаконной деятельности в области археологии". URL: http:/asozd2.duma.gov.ru/main.nsf/\%28Spravka New\%29?OpenAgent\&RN=217902-6\&02 (дата обращения: 01.12.2020).

5 Федеральный закон от 25 июня 2002 г. № 73-ФЗ «Об объектах культурного наследия (памятниках истории и культуры) народов Российской Федерации" / / Собрание законодательства Российской Федерации. 2002. № 26. Ст. 2519. 
ст. 243.2 УК РФ на отсутствие у мица, совершающего преступление, разрешения на ведение археологических полевых работ (открытого листа). Зависимость противоправных действий от наличия разрешения на проведение полевых археологических работ выступает одним из препятствий привлечения виновного к уголовной ответственности [Яковлев, А. В. и Бемякова, И. М., 2016]. Оно вносит путаницу в раскрытие признаков субъекта неквалифицированного состава преступления, предоставляя сторонникам "свободного поиска артефактов" возможность расширительного толкования их содержания 6 .

Признавая, что субъект преступления, предусмотренного ст. 243.2 УК РФ, за исключением п. «а", "б» ч. 3 указанной нормы, общий, необходимо обратиться к отдельным признакам, наиболее полно его характеризующим. Так, Э. М. Гильманов и Ю. А. Григорьев считают, что к совершению преступлений в отношении элементов археологического наследия причастны мица, имеющее специальные познания в области археологии [Гильманов, Э. М. и Григорьев, Ю. А., 2016]. Такой же позиции придерживается и Х. А. Аккаева [Аккаева, Х. А., 2018]. Н. В. Рязанова отмечает, что субъект преступиения, предусмотренного ст. 243.2 УК РФ, - это "мужчина в возрасте от 30 до 50 мет, ранее не судим, трудоустроен, положитемьно характеризуется по месту житемьства и по месту работы. Как правицо, это мюди, интересующиеся историей и культурой своей страны, родного края, однако не имеющие специального образования, воспринимающие поиск старинных предметов как хобби, увлечение. Среди рассматриваемой категории миц особой кастой выдемяются так называемые “торговцы древностями", которые участвуют в нелегальных раскопках именно с целью последующей реализации преступно добытого" [Рязанова, Н. В., 2018, с. 153].

Сходные признаки субъекта преступцения в отношении элементов археологического наследия приведены и в зарубежных публикациях. Так, согласно исследованию, проведенному во Франции, 90\% миц, занятых

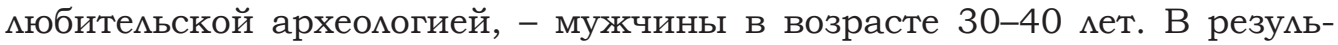
тате раздемения по социальным категориям было установлено, что 60\% из них - рабочие и ремесленники, ранее не совершавшие запрещенные законом противоправные деяния, увлекающиеся историей "отцы семейств", стремящиеся найти спрятанный клад. Правоприменительный опыт Французской Республики показывает, что после вынесения предупреждения бо́ ьшая часть представителей мюбительской археологии прекращают свою деятельность. При этом особую опасность продолжают представлять мица, ищущие археологические ценности ради извлечения прибыли от их реализации, а также пополнения собственных нелегальных комлекций древностей [Xavier, D., 2019].

6 Закон о копателях, копе, кладоискательстве и приборном поиске в России. URL: http:/hobby-detecting.ru/zakon-o-kopatelyah-kope-kladoiskatelstve-i-pribornompoiske-v-rossii-s-poyasneniyami-kommentariyami-i-sobstvennym-ponimaniem/ (дата обращения: 10.11.2020). 
Согмашаясь с суждениями отечественных и зарубежных авторов, следует отметить, что субъект преступления, предусмотренного ст. 243.2 УК РФ, домжен быть осведомлен о ценности извлекаемых из мест залегания предметов, а также должен обладать достаточным объемом знаний дмя оценки найденных артефактов. При этом не обязательно наличие специального образования: необходимые навыки он может получить в процессе само-

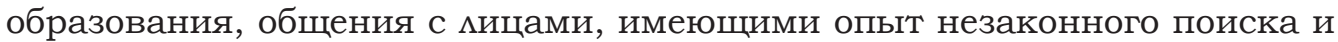
(или) изъятия археологических предметов. Определяющим явцяется то, что субъект совершаемого преступления не стремится через проводимые поисковые работы расширить научные знания об истории развития государства, народа, отдемьной социальной мибо этнической группы, а также сдемать их общедоступными [Халиков, И. А., 2020, с. 132].

Так, в соответствии с приговором Балаклавского районного суда г. Севастополя от 10 декабря 2019 г. № 1-194/2019 М. Н. и О. Ю. бъли признаны виновными в совершении преступления, предусмотренного п. "а", "в" ч. 3 cm. 243.2 УК РФ. В ходе проведенного расследования и судебного разбирательства осужденные не отрииали того, ито искали археологические предметы для пополнения собственных частных коллекиий. Они сообшили о своей осведомленности о иенностных характеристиках искомых предметов, безошибочно датировав обнаруженные на месте раскопа монеты различного периода истории Крыиского полуострова ${ }^{7}$.

На квалификацию содеянного по п. "а" ч. 3 ст. 243.2 УК РФ влияет намичие у мица, совершившего преступление, навыка, а также опыта работы со специальными техническими средствами поиска. По мнению В. С. Сердюковой и С. С. Медведева, «поиск археологических предметов протекает с помощью специального оборудования, но посредством навыков и знаний специалиста, способного как раз-таки определить их нахождение" [Сердюкова, В. С. и Медведев, С. С., 2016]. Благодаря этому формируется качественно новая характеристика субъекта преступления, применимая к большинству миц, осужденных по рассматриваемой норме уголовного закона.

Законодателем использование специальных технических средств поиска отнесено к отягчающим вину обстоятельствам. Обосновано это тем, что в результате подобных противоправных действий змоумышленники могут причинить несравнимо больший вред элементам археологического наследия. Вскрывая культурный слой на значительной по площади тер-

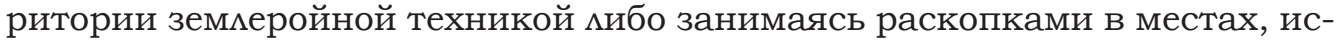
следованных с помощью метамлодетектора, мица, совершающие преступмение, могут за непродолжительное время мишить памятник археологии его кумьтурной и научной ценности.

Аицо, не осведомленное относительно возможностей поискового оборудования, не владеющее навыками его эксплуатации, не может быть

7 Приговор Балаклавского районного суда г. Севастополя от 10 декабря 2019 г. № 1-194/2019. Доступ из справочной правовой системы «КонсультантПАюс». 
субъектом преступления, предусмотренного п. «а» ч. 3 ст. 243.2 УК РФ. Намичие у правонарушителя навыков работы с указанными техническими средствами должно устанавливаться сотрудниками правоохранительных органов на стадиях проведения доследственной проверки сообщения о совершенном преступлении, расследования уголовного дема. По мнению зарубежных авторов, использование металмодетекторов как наиболее распространенного вида специальных технических средств поиска явця-

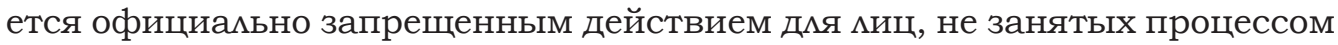
научного изучения археологического наследия. Только законное их применение может расширить возможности изучения полностью погребенных под слоем почвы исторических ценностей [Romeo, F., 2018].

Сцедует отметить, что в европейских странах различное отношение к возможности использования частными мицами специальных технических средств поиска при изучении материальной истории государства [Cleere, Н., 1993]. Так, в Великобритании существует "либеральная модель", регулирующая деятельность частных мюбителей металмопоиска. В ее основу положен приоритет права собственности над общественным интересом. В соответствии с ней создана добровольная система сотрудничества граждан и государственных учреждений по предоставмению всем желающим возможности изучения истории государства посредством оказания содействия профессиональным археологам, обследования памятника археологии с использованием специальных технических приборов поиска. Условием признания подобных действий соответствующими требованиям закона является обязательное включение обнаруживаемых предметов в общедоступные реестры (базы данных) [Bland, R., 2004]. При этом нарушители приведенных условий, как правило, не несут какой-либо ответственности [Gill, D. W. J., 2010]. В целях реализации предоставленного права поиска археологических предметов с соблюдением предъявцяемых

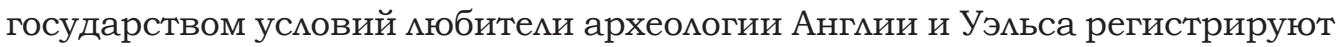
обнаруженные ими предметы на сайте Portable Antiquities Scheme (PAS)

Распространенная в континентальной части Европы (Испания, Франция, Италия) модель взаимодействия государства и археологов-любителей основана на безусловном приоритете общественного интереса в процессе сохранения объектов археологического наследия. В соответствии с ней использование метамлодетектора допустимо только при условии получения его вцадемьцем специального разрешения (Аицензии) и только на специально отведенной территории. К таким территориям отнесены пляжи, горы, т. е. места, содержащие археологические предметы в ограниченном количестве [Rodríguez, T., 2016]. Отношение большинства стран, входящих в Совет Европы, к процессу использования мюбителями археологии специальных технических приборов поиска (метамлодетекторов) нашмо отражение

8 Portable Antiquities Scheme URL: https://finds.org.uk/ (дата обращения: 18.04.2020). 
в Европейской конвенции об охране археологического наследия (пересмотренной) (ETS № 143) от 16 января 1992 г. ${ }^{9}$ Пункт «іiі» ст. 3 этого международного договора обязывает страны-участницы вести выдачу специального предваритецьного разрешения на использование металмодетекторов, иного поискового оборудования, методов их использования, но только исключительно для проведения археологических изысканий. "Как только чтото регистрируется метамлодетектором, возникает собцазн откопать это. И не важно, имеет находка большое археологическое значение или является отбросом двадцатого века" ${ }^{10}$. Ратификация Российской Федерацией Европейской конвенции определила правовую основу для уголовно-правовой охраны археологического наследия государства. Во многом благодаря ей совершение субъектом противоправных действий с использованием специальных технических средств поиска было отнесено к квалифицированному составу преступления, предусмотренному п. "а» ч. 3 ст. 243.2 УК РФ, поскольку было признано, что процесс обнаружения представляющих археологическую ценность предметов с использованием специальных приборов поиска не носит случайный характер. Используя технические средства, злоумышленники целенаправленно заняты незаконным поиском представмяющих ценность предметов, что придает признакам субъекта преступления особое смысловое наполнение.

С подобной позицией согласимась апемяяционная инстанция Костромского обцастного суда.

Материалами уголовного дела было установлено, что осужденные с использованием специальных технических средств поиска - металлоискателей и землеройных машин иеленаправленно осуществляли поиск археологических предметов на территории ранее не состоявшего под государственной охраной памятника археологии, расположенного в 500 метрах $\kappa$ западу от архитектурного комплекса Казанской и Троиикой иерквей села Бушнево Антроповского района Костромской области ${ }^{11}$.

В соответствии с п. «б» ч. 3 ст. 243.2 УК РФ преступление может быть совершено Аицом с использованием своего служебного положения. В данном случае таковым может быть представитель органа государственной охраны объектов культурного наследия Аибо профессиональный археолог. Он является специальным субъектом преступцения. При подобной ква-

9 Европейская конвенция об охране археологического наследия (пересмотренная) (принята 16 января 1992 г. в г. Валметта, Мальта) (ЕTS № 143) [рус., англ.] // Бюмлетень международных договоров. 2013. № 3. С. 41-54.

10 Explanatory Report to the European Convention on the Protection of the Archaeological Heritage (Revised). URL: https://rm.coe.int/CoERMPublicCommonSearchServices/Di splayDCTMContent?documentId=09000016800cb5e0 (дата обращения: 18.04.2020).

11 Апемляционное определение Костромского областного суда от 19 ноября 2015 г. по деку № 22-1181/2015. Доступ из справочной правовой системы «КонсультантПиюс". 
мификации содеянного вариативно возможно совершение преступником следующих противоправных действий.

Организаиия либо обшее покровительство незаконным поисковым работам на территории находящегося под государственной охраной памятника археологии. Так, к полномочиям федеральных органов государственной вцасти в соответствии с п. 5 ч. 1 ст. 9 Федерального закона № 73-ФЗ отнесены сохранение, использование и популяризация объектов культурного наследия, установцен порядок осуществцения государственного надзора в данной сфере. Сходными по объему полномочиями наделены органы государственной власти субъектов Российской Федерации и органы местного самоуправления, за искАючением функции осуществления соответствующего надзора. Законодатель в ст. 61 Федерального закона № 73-ФЗ установил возможность привлечения к уголовной ответственности должностных миц за несоблюдение требований закона, в том числе в части сохранения объектов археологического наследия. При этом действия виновного должны быть квалифицированы в соответствии с требованиями главы 7 "Соучастие в преступцении" УК РФ, а также п. "б", "В" ч. 3 ст. 243.2 УК РФ.

Незаконное проведение государственной историко-культурной экспертизы с иелью выведения земель, на которых расположены объекты археологического наследия, из-под государственной охраны для предстоящего либо уже проведенного незаконного поиска и (или) изъятия археологических предметов из мест залегания (ст. 28 Федерального закона № 73-Ф3). Наличие либо отсутствие культурного слоя памятника археологии может быть установлено исключительно в ходе проведения государственного экспертного исследования. Наравне с возможностью использования по своему усмотрению земель, на которых расположен памятник археологии, выгодоприобретатель подобных незаконных действий может

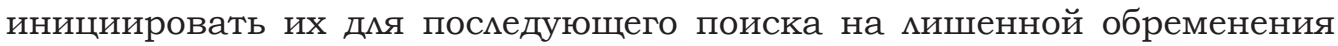
территории представляющих определенную ценность предметов.

Незаконный поиск и (или) изъятие археологических предметов лииом, обладающим специальньми профессиональньми познаниями в области археологии, иленом профессионального сообщества археологов. О необходимости привцечения к уголовной ответственности указанной категории миц, отнесенных к специальным субъектам преступления, высказались Э. М. Гильманов и Ю. А. Григорьев [Гильманов, Э. М. и Григорьев, Ю. А., 2016]. Подобные противоправные действия могут быть совершены специальным субъектом преступления - профессиональным археологом, когда он действует вопреки интересам научного сообщества. Обнаруженные при совершении подобных противоправных действий археологические предметы не вводятся в доступный к изучению научный оборот, а реализуются на теневом антикварном рынке, включаются в частные археологические коммекции. При этом специальный субъект преступцения - профессиональный археолог, представитель органа государственной охраны объектов культурного наследия - должен действовать с нарушением выданного официального разрешения (открытого миста) Аибо без его оформления. Это 
важный критерий, разграничивающий состав преступления и состав административного правонарушения, предусмотренный ст. 7.15 КоАП РФ.

Так, во Франиии была предпринята попытка привлечения $\kappa$ уголовной ответственности издателя журнала как лииа, имеюшего отношение к уничтожению памятника археологии. Вместе с тем преследование в отношении него было прекрашено, так как отсутствовала связь между журнальной публикаиией и обнаруженными археологами разрушениями [Saujot-Besnier, C., 1999], что является обоснованньм, поскольку отсутствует причинно-следственная связ между действиями журналистов и разрушением объекта археологического наследия.

\section{Обсуждение и закиючение}

Таким образом, субъектом преступления, предусмотренного ч. 1,2 п. "В" ч. 3 ст. 243.2 УК РФ, могут быть мица, отвечающие критериям, приведенным в ч. 1 ст. 20 УК РФ. Возможность совершения преступления специальным субъектом предусмотрена в п. "а", "б" ч. 3 ст. 243.2 УК РФ: это мица, обладающие навыками работы со специальными техническими средствами, позволяющими определить наличие представляющих цен-

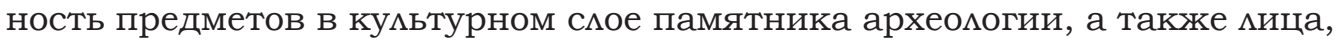
совершающие преступление с использованием своего служебного положения вопреки интересам научного сообщества и (или) интересам службы в государственном органе охраны объектов культурного наследия. В целях исключения возможности двойственности толкования признаков субъекта преступления необходимо внести изменения в диспозицию ч. 1 ст. 243.2 УК РФ, искАючив указание на необходимость привлечения к уголовной ответственности за проведение археологических полевых работ без официального разрешения (открытого миста). Как было отмечено в проведенном исследовании, действия, за которые наступает уголовная ответственность, изначально являются незаконными.

\section{Список испоцьзованной митературы}

Аккаева Х. А. Предупреждение и борьба с незаконным поиском и (или) изъятием археологических предметов из мест залегания (ст. 243.2 УК РФ) // Пробелы в российском законодатемьстве. 2018. № 3. C. 338-340.

Гимьманов Э. М., Григорьев Ю. А. О субъекте состава незаконного поиска и (ими) изъятия археологических предметов из мест залегания / / Правовые и нравственные аспекты обеспечения безопасности мичности и государства на современном этапе политических и экономических санкций : сб. материалов Всерос. науч.-практ. конф. : в 2 ч. / отв. ред. Н. В. Хураськина. Чебоксары, 2016. С. 372-374.

Клебанов $\Lambda$. Р. Уголовно-правовая охрана культурных ценностей : дис. ... д-ра юрид. наук. М., 2012. 512 с. 
Ковалев А. А. Применение понятий "археологический предмет" и "культурный слой" в правоохранительной деятельности // Сохранение археологического наследия: проблемы и перспективы : материалы науч.практ. конф. "Противодействие незаконной деятельности в области археологии", Москва, 9-10 дек. 2013 г. М.: ИА РАН, 2015. С. 8-32.

Осокин Р. Б. Теоретико-правовые основы уголовной ответственности за преступцения против общественной нравственности : дис. ... д-ра юрид. наук. М., 2014. 581 с.

Панфилов А. Н. Ключевые правовые понятия в области археологии в российском законодательстве и проблемы их правовой определенности // Вестник Тюменского государственного университета. Социально-экономические и правовые исследования. 2017. Т. 3, № 3. С. 113-136.

Рязанова Н. В. Ответственность за уничтожение или повреждение объектов культурного наследия и проблемы в ее реализации // Oxрана объектов культурного наследия: национальный и международный опыт : материалы науч.-практ. конф., В. Новгород, 25-26 окт. 2018 г. В. Новгород : Новгород. гос. ун-т им. Я. Мудрого, 2018. C. $147-155$.

Сабитов Т. Р. Охрана культурных ценностей: уголовно-правовые и криминологические аспекты : автореф. дис. ... канд. юрид. наук. M., 2016. 26 c.

Сердюкова В. С., Медведев С. С. Предмет и субъект преступления, связанного с незаконным проведением поисковых работ и археологических исследований // Science Time. 2016. № 5. С. 612-614.

Халиков И. А. Незаконная археология. Уголовно-правовые средства противодействия / под науч. ред. М. А. Ефремовой. Казань : ИПФ "Бриг", 2020. 206 с.

Яковлев А. В., Белякова И. М. Аюбительский метамлопоиск в Российской Федерации: законодательные запреты, проблемы правового регулирования и пути их устранения // Черные дыры в Российском законодательстве. 2016. № 3. С. 122-126.

Bland R. The Treasure Act and the Portable Antiquities scheme: a case study in developing public archaeology // Public archaeology / ed. N. Merriman. Routledge, 2004. P. 272-291.

Brent M. Le pillage des sites archéologiques // Revue Internationale de Police Criminelle. 1994. Vol. 448/449. P. 25-36.

Brun Y., Triboulot B. La lutte contre les atteintes au patrimoine archéologique et le trafic illicite des biens culturels // Les Nouvelles de l'archéologie. 2017. Vol. 149. P. 43-45.

Cleere H. Managing the archaeological heritage // Antiquity. 1993. № 67. P. 400-402. 
Gill D. W. J. The Portable Antiquities Scheme and the Treasure Act: Protecting the Archeology of England and Wales? // Papers from the Institute of Archaeology. 2010. Vol. 20. P. 1-11.

Karl R. On the Highway to Hell: Thoughts on Unintended Consequences for Portable Antiquities Austrian Denkmalschutzgesetz // The Historic Environment: Policy \& Practice. 2011. Vol. 2, issue 2. P. 111-133.

Rodríguez T. Rational Grounds for Dialogue Between Archaeologists and Metal Detectorists in Spain // Open Archaeology. 2016. Vol. 2, issue 1. P. $150-159$.

Romeo F. La regulacion del uso detectores de metales en la Comunidad Autonoma de Aragon // Uso de detectores de metals y arqueologia: sanciones administrativas y penales. Valencia: Tirant lo Blanch, 2018. P. 263-279.

Saujot-Besnier C. Chronique juridique. La protection pénale des vestiges terrestres // Rev. archéol. Ouest. 1999. Vol. 16. P. 227-234.

Thomas S. Editorial: Portable antiquities: archaeology, collecting, metal detecting // Internet Archaeology. 2013. Vol. 33. URL: https://doi. org/10.11141/ia.33.12

Xavier D. Le détectorisme en France: quelle situation et quelle politique publique? / / Canadian Journal of Bioethics. 2019. Vol. 2. P. 158-165.

\section{References}

Akkaeva, H. A., 2018. [Prevention and control of illegal search and (or) removal of archaeological items from their places of occurrence (art. 243.2 of the Criminal code)]. Probely $v$ rossijskom zakonodatel'stve $=$ [The Gaps in the Russian Legislation], 3, pp. 338-340. (In Russ.)

Bland, R., 2004. The Treasure Act and the Portable Antiquities scheme: a case study in developing public archaeology. In: N. Merriman, ed. Public archaeology. Pp. 272-291.

Brent, M., 1994. Le pillage des sites archéologiques. Revue Internationale de Police Criminelle, 448/449, pp. 25-36.

Brun, Y. and Triboulot, B., 2017. La lutte contre les atteintes au patrimoine archéologique et le trafic illicite des biens culturels. Les Nouvelles de l'archéologie, 149, pp. 43-45 (In Esp.).

Cleere, H., 1993. Managing the archaeological heritage. Antiquity, 67, pp. 400-402.

Gill, D. W. J., 2010. The Portable Antiquities Scheme and the Treasure Act: Protecting the Archeology of England and Wales? Papers from the Institute of Archaeology, 20, pp. 1-11.

Gil'manov, E. M. and Grigor'ev, Yu. A., 2016. [About the subject of the composition of the illegal movement, and (or) the seizure of archaeo- 
logical objects around the places of occurrence]. In: N. V Khuras'kina, ed. Pravovyye i nravstvennyye aspekty obespecheniya bezopasnosti lichnosti i gosudarstva na souremennom etape politicheskikh $i$ ekonomicheskikh sanktsiy $=[$ Legal and moral aspects of ensuring the security of the individual and the state at the present stage of political and economic sanctions]. Collection of materials of the All-Russian scientific and practical conference. In 2 vols. P. 372-374. (In Russ.)

Karl, R., 2011. On the Highway to Hell: Thoughts on Unintended Consequences for Portable Antiquities. Austrian Denkmalschutzgesetz. The Historic Environment: Policy \& Practice, 2(2), pp. 111-133.

Khalikov, I. A., 2020. Nezakonnaya arheologiya. Ugolovno-pravovye sredstva protivodejstviya $=$ [Illegal archaeology. Criminal legal means of counteraction]. Monograph. Ed. M. A. Efremova. Kazan: IPF "Brig". (In Russ.)

Klebanov, L. R., 2012. Ugolovno-pravovaya ohrana kul'turnyh cennostej $=[$ Criminal legal protection of cultural property $]$. Dr. Sci. (Law) Dissertation. Moscow. (In Russ.)

Kovalev, A. A., 2015. [Application of the concepts of "archaeological object" and "cultural layer" in law enforcement]. Sokhraneniye arkheologicheskogo naslediya: problemy $i$ perspektivy $=$ [Preservation of the archaeological heritage: problems and prospects]. Materials of scientific-practical conference "Countering illegal activities in the field of archeology”. Moscow, December 9-10, 2013. Moscow. Pp. 8-32. (In Russ.) Osokin, R. B., 2014. Teoretiko-pravovye osnovy ugolovnoj otvetstvennosti za prestupleniya protiv obshchestvennoj nravstvennosti $=$ [Theoretical and legal foundations of criminal liability for crimes against public morality]. Dr. Sci. (Law) Dissertation. Moscow. (In Russ.)

Panfilov, A. N., 2017. [Key legal concepts in the field of archeology in Russian legislation and problems of their legal certainty]. Vestnik Tyumenskogo gosudarstvennogo universiteta. Social'no-ekonomicheskie $i$ pravovye issledovaniya $=[$ Bulletin of the Tyumen State University. Socio-Economic and Legal Research], 3, pp. 113-136. (In Russ.)

Rodríguez, T., 2016. Rational Grounds for Dialogue Between Archaeologists and Metal Detectorists in Spain. Open Archaeology, 2(1), pp. 150159.

Romeo, F., 2018. La regulacion del uso detectores de metales en la Comunidad Autonoma de Aragon. In: Uso de detectores de metals y arqueologia: sanciones administrativas y penales. Valencia: Tirant lo Blanch. Pp. 263-279.

Ryazanova, N. V., 2018. [Responsibility for the destruction or damage of cultural heritage objects and problems in its implementation]. Okhrana ob'yektov kul'turnogo naslediya: natsional'nyy i mezhdunarodnyy opyt 
$=[$ Protection of cultural heritage sites: national and international experience]. Materials of scientific-practical conferens, V. Novgorod, October 25-26, 2018. V. Novgorod: Ya. Mudryy Novgorod State University. Pp. 147-155. (In Russ.)

Sabitov, T. R., 2016. Ohrana kul'turnyh cennostej: ugolovno-pravovye $i$ kriminologicheskie aspekty $=$ [Protection of cultural property: criminal law and criminological aspects]. Abstract of Cand. Sci. (Law) Dissertation. Moscow. (In Russ.)

Saujot-Besnier, C., 1999. Chronique juridique. La protection pénale des vestiges terrestres. Rev. archéol. Ouest, 16, pp. 227-234.

Serdyukova, V. S. and Medvedev, S. S., 2016. [Object and subject of a crime related to the illegal conduct of search operations and archaeological research ]. Science Time, 5(29), pp. 612-614. (In Russ.)

Thomas, S., 2013. Editorial: Portable antiquities: archaeology, collecting, metal detecting. Internet Archaeology, 33. Available at: <https:// doi.org/10.11141/ia.33.12>.

Xavier, D., 2019. Le détectorisme en France: quelle situation et quelle politique publique? Canadian Journal of Bioethics, 2, pp. 158-165.

Yakovlev, A. V. and Belyakova, I. M., 2016. [Amateur metal search in the Russian Federation: legal prohibitions, problems of legal regulation and ways to eliminate them]. Chernye dyry $v$ Rossijskom zakonodatel'stve = [Black Holes in Russian Legislation], 3, pp. 122-126. (In Russ.)

\section{Информация об авторе / Information about the author}

Хамиков Искандер Амьфредович, кандидат юридических наук, старший преподаватель кафедры прокурорского надзора за исполнением законов в оперативно-розыскной деятельности и участия прокурора в угомовном судопроизводстве Казанского юридического института (филиала) ФГКОУ ВО “Университет прокуратуры Российской Федерации" (Российская Федерация, 420111, г. Казань, ум. Московская, д. 41)

Iskander A. Khalikov, Cand. Sci. (Law), Senior Lecturer of the Prosecutorial Supervision over the Execution of Laws in Operational-Investigative Activities and Participation of the Prosecutor in Criminal Proceedings Department, Kazan Law Institute (Branch), University of Prosecutor's office of the Russian Federation (41 Moskovskaya St., Kazan, 420111, Russian Federation).

E-mail: iskanderh@mail.ru

Дата поступления рукописи в редакцию издания: 15.12.2020; дата одобрения после рецензирования: 22.01.2021; дата принятия статьи к опубликованию: 02.02.2021.

Submitted 15.12.2020; reviewed 22.01.2021; revised 02.02.2021. 
УДК 347.721

DOI: $10.37399 / 2686-9241.2021 .1 .128-147$

\title{
Обязанности участников корпорации
}

\author{
Н. Д. Грибов \\ ФГБОУВО «РОссийский государственный университет \\ правосудия», г. Москва, Российская Федерация \\ ng.law@yandex.ru
}

\begin{abstract}
Аннотация
Введение. В статье анализируются обязанности участников корпорации. В российской и зарубежной доктрине внимание уделяется главным образом обязанностям лиц, входящих в органы управления корпорацией. Поэтому вопрос об обязанностях участников корпорации имеет высокий научный интерес.

Теоретические основы. Методы. Проанализированы доктрины корпоративного права в российской и зарубежной науке. В процессе изучения обязанностей участников автор опирался на системный, сравнительный методы, проблемно-теоретический прием исследования.

Результаты исследования. Рассмотрены конкретные обязанности участников корпорации. Обозначены проблемы, возникающие в сфере правового содержания и имплементации ряда обязанностей участников корпорации. Отграничена обязанность действовать добросовестно от обязанности не допускать действий, направленных на злоупотребление правом. На основе анализа зарубежной литературы раскрывается фидуциарная обязанность участников корпорации. Выделяются меры корпоративной ответственности участников за неисполнение обязанностей.

Обсуждение и заключение. В результате исследования автор пришел к выводам, что обязанности участников следует подразделять на основные и дополнительные. К основным обязанностям участников корпорации следует относить следующие: не допускать злоупотребления корпоративными правами, действовать добросовестно, участвовать в образовании имущества корпорации, не разглашать конфиденциальную информацию о деятельности корпорации, заблаговременно уведомлять корпорацию и ее участников о намерении обратиться с косвенным иском, раскрывать определенную информацию. Обязанность действовать добросовестно и обязанность не допускать действий, направленных на злоупотребление правом, по своему содержанию различаются. Фидуциарная обязанность участников корпорации фактически приравнивается к обязанности действовать добросовестно. Невыполнение участником корпоративных обязанностей может повлечь следующие меры корпоративной ответственности: исключение участника из корпорации, приостановление права голоса, фринансовые санкции.
\end{abstract}

Ключевые слова: обязанности участников корпорации, добросовестность, злоупотребление правом, фидуциарная обязанность, корпоративная ответственность

Для цитирования: Грибов Н. Д. Обязанности участников корпорации // Правосудие/ Justice. 2021. T. 3, № 1. С. 128-147. DOI: 10.37399/2686-9241.2021.1.128-147. 


\title{
Obligations of Corporation Members
}

\author{
Nick D. Gribov \\ Russian State University of Justice, Moscow, Russian Federation \\ For correspondence: ng.law@yandex.ru
}

\begin{abstract}
Introduction. The article is devoted to the analysis of the obligations of corporation members in Russian and foreign law. In the Russian and foreign doctrines, attention is paid to the duties of directors or controlling persons. Therefore, the legal question of the obligation of the corporation members is of high scientific interest.

Theoretical Basis. Methods. The author analyzed the doctrines of corporate law in Russian and foreign science. In the process of studying the obligations of the corporation members, the author relied on systemic, comparative methods, and a problem-theoretical method of research.

Results. Specific obligations of the corporation members are considered. The issues arising in the field of legal content and implementation of several obligations of the corporation members are outlined. The obligation to act in good faith has been differentiated from the obligation to prevent actions aimed at an abuse of rights. Based on the analysis of foreign literature, the fiduciary duty of the corporation members is demonstrated. The responsibilities of the corporation members for non-performance of obligations are also highlighted.

Discussion and Conclusion. As a result of the research, the author concludes that the responsibilities of the corporation members should be divided into two categories, namely basic and additional. The basic obligations of the corporation members should include the following: to prevent abuse of corporate rights, to act in good faith, to participate in the formation of the corporation's property, not to disclose confidential information about the corporation's activities, to notify the corporation and its members in advance of their intention to file a directive claim, and to disclose information. The obligation to act in good faith and the obligation to prevent actions aimed at abusing the right differ in their content. The fiduciary duty of the members of the corporation is, in fact, the same as the obligation to act in good faith. Failure by a member to comply with corporate obligations may entail the following measures of corporate responsibility: exclusion of the participant from the corporation, suspension of voting rights, financial sanctions.
\end{abstract}

Keywords: duties of the corporation members, good faith, abuse of the law, fiduciary duty, corporate responsibility

For citation: Gribov, N. D., 2021. Obligations of corporation members. Pravosudie/Justice, 3(1), pp. 128-147. DOI: 10.37399/2686-9241.2021.1.128-147.

\section{Введение}

С момента возникновения корпоративных отношений их участники приобретают права и обязанности. Права участников корпорации - это совокупность прав, которыми обладают участники корпорации благодаря владению акциями [Idowu, S. O., et al., eds., 2013]. В юридической $и$ тературе отмечается, что участники корпорации, в отмичие от директора, пользуются правами в своем интересе [De Jongh, M., 2012, p. 185]. Однако современное состояние корпоративного права и тенденции его развития показывают, что участники при реализации их прав должны руководствоваться определенными пределами. С 1970-х годов в доктрине отмечается, что без подотчетности управляющие и мажоритарные акцио-

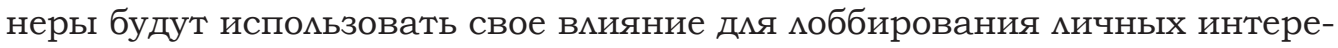
сов за счет миноритарных участников [Armour, J., 2020, p. 316]. Поэтому 
обязанностям членов корпорации уделяется все больше внимания в научной цитературе. Ведь именно обязанности являются пределами реализации прав участников корпоративных отношений. Так, Кодекс корпоративного управцения Нидерландов закрепляет важное положение: чем больше интерес акционера к компании, тем больше его ответственность перед компанией, миноритарными акционерами и другими заинтересованными сторонами ${ }^{1}$.

Обязанности участников корпорации различаются в зависимости от национальной юрисдикции. Обязанности участников корпорации могут устанавливаться законом, следовать из общих принципов, закрепленных в нормативных актах, быть установцены в мокальных актах юридического мица, корпоративном договоре и других документах, а также быть выработаны национальными судами [Søndergaard, B. and Möslein, F., 2017, p. 2]. В зависимости от источника, где они зафиксированы, обязанности участников корпорации можно подразделить на два вида: основные и дополнительные. Первые устанавливаются в законе, например обязанность участвовать в образовании имущества корпорации, закрепленная в российском законодательстве. Дополнительные обязанности могут быть предусмотрены учредительными документами корпорации, соглашением об управлении партнерством. Установление дополнительных обязанностей зависит от воцеизъявления других участников корпоративных правоотношений.

При этом в российской науке корпоративного права распространена позиция, согласно которой корпоративная ответственность возмагается преимущественно на участников, контролирующих деятельность корпорации, а миноритарии несут мишь универсальную обязанность не совершать умышленных действий по причинению вреда корпорации [Гутников, О. В., 2015]. Вместе с тем подобную позицию следует оценить критически. Основой такой оценки выступает то, что миноритарные акционеры могут вступать в сговор в целях моббирования определенных корпоративных решений. Данными действиями они не причиняют вред корпорации, поскольку поддерживают опредеменный взгляд на развитие юридического мица. Однако их действия можно расценивать как недобросовестные, так как вместо выработки "золотой середины" с другими участниками они отстаивают собственные эгоистичные интересы. Кроме того, миноритарии, как и мажоритарные акционеры, должны раскрывать опредеменную информацию перед корпорацией, уведомлять корпорацию и ее участников о намерении обратиться с косвенным иском. Та-

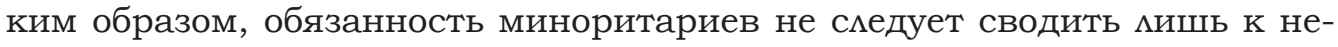
причинению вреда корпорации.

1 In review: shareholder rights and responsibilities in Netherlands // Lexology. URL: https: / / www.lexology.com/library/detail.aspx?g=30911ab5-f50d-4d3a-854726914f824d0a (дата обращения: 24.07.2020). 


\section{Теоретические основы. Методы}

Объектом исследования являются обязанности участников корпорации, установценные в зарубежном и российском корпоративном праве. В работе использован комплекс научных методов. В частности, на основе системного метода раскрываются место и роль обязанностей участников корпорации.

Сравнительный метод исследования позволил выявить круг обязанностей участников корпорации, сформировать перечень мер корпоративной ответственности за несоблюдение обязанностей. Проблемно-теоретический прием исследования позволиц обозначить проблемные вопросы, которые требуют изучения в правовой науке.

\section{Резуцьтаты иссиедования}

На основе анализа доктринальных источников и законодательства автор пришел к выводу, что следует выделять следующие обязанности участников корпорации.

Обязанность не допускать злоупотребления корпоративными правами. Данная обязанность действует в отношении всех участников корпоративных отношений и является универсальной. Осуществление прав одним участником корпоративных отношений не должно нарушать прав другого участника. Так, российский арбитражный суд указал, что обращение с иском о признании отсутствия у руководителя общества права действовать без доверенности от имени общества в обход корпоративных процедур выбора руководителя общества при недостижении согласия акционеров явцяется зцоупотребцением правом со стороны истца ${ }^{2}$.

Соответственно, змоупотребление корпоративным правом следует толковать как намеренные действия (бездействие) участника корпоративных отношений, направленные на причинение вреда иным участникам данных правоотношений. Относитецьно эцементов конструкции зцоупотребления правами в российской науке высказано много точек зрения. Представляется, что дмя установцения змоупотребления корпоративными правами необходимы три элемента: 1) наличие действий (бездействия), 2) отсутствие добросовестности, 3) намерение причинить вред третьим мицам. Только суд правомочен признавать соответствующие действия (бездействие) змоупотреблением правом.

Правом могут зцоупотребцять как миноритарные, так и мажоритарные акционеры. Установцение наличия зцоупотребления правом со стороны акционеров происходит путем оценки принятого решения на наличие ущерба интересам корпорации и другим акционерам.

2 Решение Арбитражного суда Тамбовской области от 19 июня 2020 г. по дему № A64-8165/2019. URL: https://tinyurl.com/y4ydco6k (дата обращения: 23.07.2020). 
Так, судь во Франиии могут установить злоупотребление мажоритарными акиионерами свочми правами, если, голосуя против выплаты дивидендов, они заставляют миноритарных акиионеров продать свои акиии со значительной скидкой [Сопас, P., 2017, р. 366]. Миноритарии могут злоупотреблять правами путем блокирования решения обшего собрания, требуюшего единогласного одобрения и направленного на соблюдение интересов корпораuиu.

В российском законодательстве, по мнению автора, закреплены две обязанности участников, фактически явцяющиеся частным случаем запрета зцоупотребления правом.

Первая обязанность, в США выступающая частью фидуциарной обязанности, заключается в запрете на совершения действий, заведомо направленных на причинение вреда корпорации. Данная обязанность может применяться в совокупности с обязанностью участвовать в принятии корпоративных решений, так как участник, не посетивший собрание, может считаться причинившим вред корпорации. В российской научной митературе утверждается, что закрепление обязанности не совершать действия, заведомо направленные на причинение вреда корпорации, в корпоративном законодательстве достаточно спорно, так как обязанность не причинять вред является общегражданской и ее нарушение вцечет возникновение обязательства из причинения вреда в симу конструкции генерального демикта [Гутников, О. В., 2015]. Вместе с тем с данной позицией вряд ми можно согласиться, поскольку, причиняя вред корпорации, участник одновременно совершает генеральный деликт и нарушает корпоративную обязанность. В результате этого общество может:

1) подать иск о привцечении участника к гражданской ответственно-

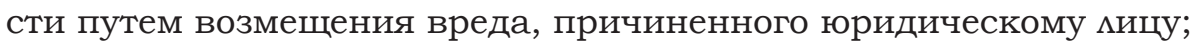

2) предъявить в арбитражный суд иск о привлечении к корпоративной ответственности путем исключения участника из корпорации, основываясь на нормах корпоративного законодательства;

3) заявить в иске одновременно два данных требования.

Вторая обязанность заключается в запрете совершения действий (бездействия), которые существенно затрудняют или делают невозможным достижение целей, ради которых создана корпорация. На первый взгляд данная обязанность идентична обязанности не совершать действия, заведомо направленные на причинение вреда корпорации, так как совершение действий, направценных на дестабилизацию целей корпорации, наносит ей вред. Однако в данном случае, как отмечается в юридической митературе, речь идет не о причинении вреда имуществу корпорации, а о воспрепятствовании участником корпорации достижению основных целей ее создания. Например, как отмечает правовед Е. А. Суханов [Бадулина, Е. В. и др., 2014], участник некоммерческой корпорации может попытаться направить ее деятельность в иную сферу, нежели та, которая 
была предусмотрена при ее создании (например, в общественно-политическую, а не в благотворительную). Подобные действия участника нано-

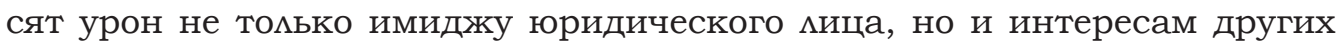
членов корпорации. Поскольку фактически идет речь о причинении вреда третьим мицам, которыми выступают иные участники, данную обязанность следует рассматривать в качестве частного случая змоупотребмения правом.

Обязанность участия в принятии корпоративных решений. Конструкция права на участие может при наличии ряда условий трансформироваться в обязанность участия. В соответствии с российским законодательством обязанность участия возникает при наличии двух условий.

Во-первых, если на общем собрании принимаются решения, без которых корпорация не может продомжать свою деятельность в соответствии с законом. К таким решениям, в частности, относятся решения о назначении единоличного исполнительного органа или членов совета директоров, а также о внесении изменений в устав, если они требуются в соответствии с законом и без их внесения корпорация не сможет продолжать свою деятельность ${ }^{3}$. Таким образом, право участия не трансформируется в обязанность, если принимаются иные решения, хоть и требующие единогмасного принятия.

Во-вторых, участник корпорации обладает значимостью дмя принятия решения. Второе условие, закрепленное в законодательстве, следует оспорить, так как в некоторых случаях значимость участника определить достаточно трудно. Так, для избрания единоличного исполнительного органа общества необходимо простое большинство ${ }^{4}$. Если игнорирует общее собрание мажоритарный участник, то опредемить трансформацию права в обязанность не составцяет проблемы. Однако когда в обществе более десяти участников с равными домями, то уже возникают вопросы, дмя кого из участников право преобразовалось в обязанность. Поэтому представцяется, что трансформация права в обязанность участия в принятии корпоративных решений зависит от принимаемого решения: если оно существенное, то обязанность участия возникает дия всех участников корпорации.

Обязанность действовать добросовестно (the duty of good faith or bona fide). В российском праве данная обязанность закреплена в ст. 1, 10

3 См. п. 34 Постановцения Пленума Верховного Суда Российской Федерации от 23 июня 2015 г. № 25 "О применении судами некоторых положений раздема I части первой Гражданского кодекса Российской Федерации". Доступ из справочной правовой системы «КонсультантПиюс» (дата обращения: 25.05.2020).

4 См. абз. 1 п. 1 ст. 40 Федерального закона от 8 февраля 1998 г. № 14-ФЗ (ред. от 31 июля 2020 г.) "Об обществах с ограниченной ответственностью". Доступ из справочной правовой системы “КонсультантПцюс» (дата обращения: 25.05.2020). 
Гражданского кодекса Российской Федерации дия всех участников гражданских и корпоративных правоотношений. В отечественной науке корпоративного права имеется точка зрения, согласно которой корпоративную добросовестность следует рассматривать только применительно к ответственности и обязанностям органов юридического мица [Новак, Д. В., 2017]. Подобную позицию следует оценить критически и согласиться с точкой зрения о более широком толковании добросовестности в корпоративных отношениях [Нам, К. В., 2019]. Добросовестность нельзя сводить только к отношениям органа управцения и корпорации, она проявцяется и в отношениях между обществом и участниками, и в отношениях между самими участниками. Добросовестность адресована непосредственно участникам гражданского оборота в области тех отношений, которые достойны внимания права, а ее наполнение смыслом поручено судам [Асосков А. В. и др., 2020, с. 182].

Так, Коммерческая палата Аюксембургского районного суда усмотрела, ито для определения факта недобросовестности со стороны миноритарных участников суд обязан проанализировать значение решения, отклоненного меньшинством, в частности необходимость этого решения для выживания компании, нивелирования ее несостоятельности или же направленности действий миноритариев на затруднение функиионирования компании либо достижение эгоистичных иелей.

Обязанность действовать добросовестно в рамках корпоративных правоотношений следует рассматривать в двух аспектах:

1) участник юридического мица должен совершать опредеменные действия (этот аспект можно толковать как активную добросовестность);

2) участник корпорации должен воздержаться от совершения опредеменных действий (этот аспект можно толковать как пассивную добросовестность) [Нам, К. В., 2019].

Рассмотрим пример активной добросовестности.

Обществом бъло принято решение о созыве общего собрания участников, в повестку включен вопрос о назначении единоличного исполнительного органа. Мажоритарный участник за несколько дней до проведения общего собрания попадает в медицинское учреждение и в силу физической невозможности посетить собрание не может. Обязанность участвовать в принятии корпоративных решений он не нарушает, так как есть уважительные причины неявки. Обязанность действовать разумно и добросовестно, в рамках данного случая проявляется в необходимости для этого участника известить общество о непредвиденных обстоятельствах.

В качестве примера пассивной добросовестности можно привести отказ в предъявлении заранее проигрышных косвенных исков, отказ от

5 Luxembourg District Court defines conditions of minority abuse at shareholders' meetings. Lexology. URL: http://tinyurl.com/y28d3bhr (дата обращения: 15.05.2020). 
осуществления конкурирующей предпринимательской деятельности и получения корпоративной информации о деятельности общества в целях экономической выгоды.

Так, в российской судебной практике требование участника обшества о предоставлении информаиии признается недобросовестньм, если он является конкурентом обиества, а распространение информаиии может причинить вред коммерческим интересам ${ }^{6}$. Также иллюстраиией пассивной добросовестности является отказ в реализаиии права на голосование, когда рассматриваемый вопрос касается соглашения, которое вызывает коллизию интересов ${ }^{7}$.

Интерес представцяет вопрос о соотношении обязанности не зцоупотреблять правом и обязанности действовать разумно и добросовестно. Как правило, российские суды, устанавцивая недобросовестность (mala fides), одновременно указывают и на наличие змоупотребления правом.

Так, в деле "ООО “Бритстар" о восстановлении корпоративного контроля суд указал, ито в действиях истиа имеются явные признаки злоупотребления правом на зашиту и недобросовестное поведение.

На наш взгляд, обязанность действовать добросовестно по своему содержанию шире, нежели обязанность не допускать злоупотребления корпоративными правами, поскольку обязанность осуществцять права bona fide охватывает и те случаи, которые не подпадают под зцоупотребление правом. Аицо, зцоупотребляющее правом, всегда имеет намерение при-

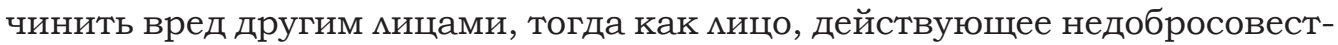

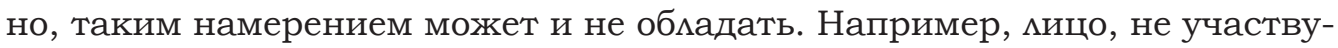
ющее в общих собраниях и игнорирующее их, не намерено причинить вред третьим мицам, однако непосещение им собраний может провоцировать корпоративный конфиикт в том случае, если его голос является решающим. Таким образом, данное мицо действует mala fides, но не змоупотребцяет своим правом.

Соответственно, обязанность действовать разумно и добросовестно по своему содержанию шире обязанности не допускать зцоупотребления корпоративными правами, поскольку она распространяется и на те слу-

6 Постановление ФАС Уральского округа от 14 ноября 2012 г. № Ф09-10061/12 по дему № А50-2205/2012. Доступ из справочной правовой системы “КонсультантПцюс" (дата обращения: 25.05.2020).

7 In brief: shareholder rights and powers in Spain // Lexology. URL: https://www. lexology.com/library/detail.aspx?g=af5ab10c-cfcd-4543-92f4-510b98eb250f (дата обращения: 25.05.2020).

8 Определение Девятого арбитражного апемяяционного суда от 2 июля 2020 г. по дему № А40-107898/19. Доступ из справочной правовой системы «КонсультантПиюс" (дата обращения: 25.05.2020). 
чаи, где участник не змоупотребляет правами, а действует недобросовестно.

Фидуииарные обязанности участников корпораиии. Конструкция фидуциарных обязанностей применяется в странах континентальной правовой семьи. Основой фидуциарной обязанности является интерес бенефициара. В корпоративном праве распространяют фидуциарные обязанности в основном на менеджеров корпорации. Фидуциарные обязанности складываются из двух составцяющих: обязанности проявцять мояльность (duty of loyalty) и обязанности проявлять заботу (duty of care) [Anabtawi, I. and Stout, L., 2008, p. 1262].

Дия участников корпорации фидуциарные обязанности можно свести

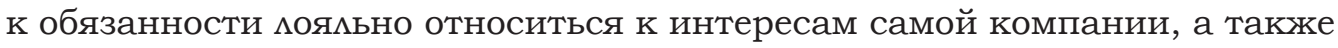
всех ее участников [Grantham, R., 1998, p. 577]. Также в рамках моямьности участник обязан воздерживаться от причинить вред участникам корпоративных отношений [Bratina, B. and Jovanovič, D., 2014]. Цемью фидуциарной обязанности выступает предотвращение возможности зцоупотребления правом, особенно правом на участие в корпорации [Cahn, А., 2017, p. 348]. При этом возможность распространения фидуциарной обязанности на акционеров зависит от усмотрения судей, которое обусловлено структурой компании, позиции в ней акционера [Bratina, B. and Jovanovič, D., 2014].

В США суды применяют фидуциарную обязанность к акционерам в следующих случаях. Во-первых, при отклонении сделки по слиянию суд вправе применять фидуциарную обязанность к контролирующим акционерам. Во-вторых, суды применяли фидуциарные обязанности к контромирующим акционерам непубличных корпораций, поскольку подобные организации сходны с партнерскими отношениями, где партнеры обязаны друг другу. В-третьих, некоторые американские суды применяют фидуциарные обязанности по отношению к миноритарным акционерам, например, когда они обладают возможностью наложить вето на опредеменные решения [Varottil, U., 2020].

Немецкие суды воспринимают фидуциарную обязанность через призму добросовестности участников юридического мица [Смирнова, Я. А., 2019, с. 123]. В частности, акционеры обязаны действовать в интересах других, вкАючая интересы миноритарных акционеров и компании [De Jongh, M., 2012, p. 191]. Аналогично и в английском праве, которое не распространяет фидуциарные обязанности на акционеров, однако английские суды усматривают, что участники должны голосовать bona fide в интересах компании как таковой [Varottil, U., 2020]. Кроме того, в Англии акционеры для своей защиты могут воспользоваться инструментом unfair prejudice.

В научной $и$ рературе отмечается, что концепция добросовестности охватывает и иные ситуации, которые не подпадают под фидуциарные обязанности [Ponta, A., 2016, p. 118]. Однако в данных работах фидуци- 
арные обязанности рассматриваются преимущественно по отношению к обязанностям менеджмента корпорации. Представцяется, что обязанность участника проявцять моямьность следует приравнивать к обязанности действовать добросовестно, так как по своему содержанию и цели она аналогична обязанности осуществцять действия в соответствии с доброй совестью.

Подобная позиция нашла отражение в российской судебной практике.

Взыскивая убытки с контролируюших корпораиию лии, включая мажоритарных акиионеров, судьи обязаны установить неразумное или недобросовестное поведение либо нарушение интересов юридического лииа 9 . При этом убытки, причиненные действиями контролируюших корпораиию лии, взыскиваются в пользу обиества, а не других акиионеров [Смирнова, Я. А., 2018, с. 41].

Обязанность участвовать в образовании имуиества корпораиии. Данная обязанность у участника возникает перед корпорацией, которая явцяется участником имущественного оборота, поэтому ей требуются активы дия достижения поставленных перед ней целей. Активы юридиче-

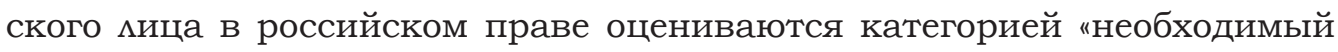
размер", которая явцяется оценочной и зависит от вида предприниматемьской деятемьности.

Так, в одном из судебных актов в ралках дела о банкротстве суды изменили очередность удовлетворения требования на том основании, что уже на начальном этапе учредителям обиества было заведомо известно, ито организаиия не имеет возможности вести нормальную предпринимательскую деятельность в сфере создания крупных объектов недвижимости ввиду очевидного несоответствия полученного ею имушества объему планируемых мероприятий (создание офисного иентра) ${ }^{10}$.

В российском праве содержание рассматриваемой обязанности зависит от формы корпорации. Так, дмя общества с ограниченной ответственностью оно вкцючает обязанность участника оплатить долю в уставном капитале и вносить вкцады в имущество общества. Дия акционерного общества данная обязанность заключается в законодательном требовании оплаты акций. Для саморегулируемой организации обязанность участво-

9 См. п. 7 Постановцения Пценума Верховного Суда Российской Федерации от 21 декабря 2017 г. № 53 "О некоторых вопросах, связанных с привлечением

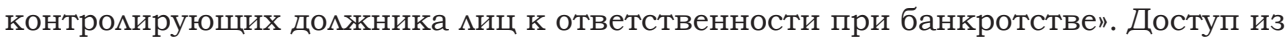
справочной правовой системы “КонсультантПцюс» (дата обращения: 25.05.2020).

10 См. п. 9 Обзора судебной практики разрешения споров, связанных с установцением в процедурах банкротства требований контролирующих должника и аффилированных с ним миц, утвержденного Президиумом Верховного Суда Российской Федерации 29 января 2020 г. Доступ из справочной правовой системы «КонсультантПцюс" (дата обращения: 25.05.2020). 
вать в образовании имущества корпорации проявцяется в оплате вступительных, членских и целевых взносов ${ }^{11}$.

В международной практике в целях защиты кредиторов юридического мица обязанность по внесению имущества может возникать и в случае, когда корпорация терпит убытки. Так, ст. 19 Второй директивы о компаниях Европейского союза закрепляет, что при серьезной потере активов корпорации юридическим мицом должно быть созвано общее собрание для решения вопроса о миквидации корпорации или принятия каких- ибо иных мер ${ }^{12}$.

Возможными правовыми последствиями неопцаты доли являются: 1) утрата статуса участника общества и переход не опмаченной участником доли в уставный капитал к обществу, мибо 2) исключение участника из общества, если неоплата доли являлась грубым нарушением обязанности участника корпорации, или 3) при выходе из общества оплата действительной стоимости части доми участнику, пропорциональной оплаченной части вклада.

Обязанность не разглашать конфиденииальную информаиию о деятельности корпораиии. Данная обязанность возникает у участника по отношению к корпорации. Право на получение информации переходит в обязанность по неразглашению с момента получения участником доступа к конфиденциальной информации. Под конфиденциальной информацией следует понимать мюбые сведения, которые не могут быть пе-

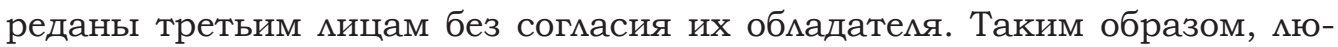
бая информация, не размещенная корпорацией публично, подпадает под категорию конфиденциальности, и ее разглашение влечет опредеменные правовые последствия, например исключение участника из корпорации. Особый режим в корпорациях установлен для коммерческой тайны. По

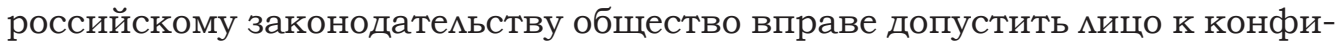
денциальной информации только после заключения соглашения о конфиденциальности. Перечень информации, подпадающей под коммерческую тайну, определяется мокальными актами, в частности положением о коммерческой тайне. Отсутствие расписки от участника о неразглаше-

11 См. ст. 12 Федерального закона от 1 декабря 2007 г. № 315-Ф3 (ред. от 3 августа 2018 г.) "О саморегулируемых организациях". Доступ из справочной правовой системы «КонсуцьтантПцюс» (дата обращения: 25.05.2020).

12 Directive 2012/30/EU of the European parliamoent and of the council of 25 October 2012 on coordination of safeguards which, for the protection of the interests of members and others, are required by Member States of companies within the meaning of the second paragraph of Article 54 of the Treaty on the Functioning of the European Union, in respect of the formation of public limited liability companies and the maintenance and alteration of their capital, with a view to making such safeguards equivalent. URL: https://eur-lex.europa.eu/legal-content/EN/ ALL/?uri=CELEX\%3A32012L0030 (дата обращения: 15.05.2020).

Правосудие/Justice. T. 3, № 1. 2021. Оригинальные статьи 
нии информации выступает законным отказом в предоставцении данных и не нарушает его права на контроць ${ }^{13}$.

Обязанность заблаговременного уведомления корпораиии и ее участников о намерении обратиться с косвенньм иском. В российском законодатемьстве данная обязанность установцена п. 2 ст. 65.2 Гражданского кодекса Российской Федерации, порядок уведомления регламентирован законами о корпорациях и учредительным документом корпорации. При этом порядок, установценный мокальными актами, не домжен приводить к существенным препятствиям обращения истца в суд. Как правило, требуется направление только уведомления о намерении подать иск, копии самого искового заявления не направляются. В публичном акционерном обществе сведения направцяются через само общество. Следует отметить, что правицо о заблаговременном уведомлении участников соответствующего гражданско-правового сообщества о намерении обратиться с иском в суд не является досудебным порядком урегулирования спора, в связи с чем в случае невыполнения истцом указанных требований суд не вправе оставить исковое заявцение без рассмотрения. Правовым последствием ненадмежащего уведомления о намерении обратиться в суд является возможность предъявцения тождественного иска другим участником корпорации.

Обязанность участника раскрывать информаиию. Участники общества обязаны раскрывать дия других участников или корпорации опредеменную информацию: сведения о мичности акционера, его аффилированности с другими корпорациями и участниками этой корпорации, поведении или намерении участника, заключении корпоративного договора между участниками [Sørensen, K. Е., 2017, р. 330]. Например, в российском праве участник общества с ограниченной ответственностью обязан своевременно информировать общество об изменении сведений о своем имени или наименовании, месте жительства или месте нахождения, а также сведений о принадлежащих ему долях в уставном капитале общества.

В Великобритании за неразглашение информаиии о бенефиииарах владельиа акиий может наступить уголовная ответственность [Birkmose, $H$. S. and Sergakis, K., 2019, p. 154]. В некоторых юрисдикииях установлен срок для реализаиии действий по раскрытию информаиии. Следует отметить, что в иелях раскрытия прозрачности владения Вторая директива Европейского союза по вопросам прав акиионеров закрепила обязанность государствчленов обеспечить, чтобы компании могли получать информаиию об идентичности акиионеров от любого посредника в иепоке посредников ${ }^{14}$. Такая

13 См., например: Постановцение Арбитражного суда Центрального округа от 5 марта 2020 г. № Ф10-441/2020 по делу № А14-672/2019. Доступ из справочной правовой системы “КонсультантПАюс» (дата обращения: 25.05.2020).

14 Shareholders Rights Directive II [2019] // Lexology. URL: https://www.lexology. com/library/detail.aspx?g=bd1f3ff5-d433-4216-9308-0915281df9fe (дата обращения: 10.10 .2020$)$. 
мера направлена на нивелирование злоупотребления правом, так как часто акиионер компании остается тот же, однако собственники в рамках юридического лииа меняются.

Дополнительные обязанности. По российскому законодательству данные обязанности могут быть предусмотрены учредительными документами корпорации, соглашением об управлении партнерством. Так, в ст. 4.10.10 Устава ООО "Союз машиностроителей России" установмена обязанность Аичным примером и своими действиями помогать достижению целей и решению задач организации ${ }^{15}$. В пункте 6.3 Устава Саморегумируемой организации "Союз менеджеров и арбитражных управляющих" зафиксировано, что чиен корпорации обязан представцять юридическому мицу для оперативного решения вопросов, связанных с деятельностью организации, необходимую информацию и документы в порядке и в сроки, опредеменные внутренними документами ${ }^{16}$.

Ответственность за невыполнение корпоративных обязанностей. Корпоративная ответственность представляет гражданско-правовую ответственность, обусловленную участием в отношениях, связанных с управлением корпорацией [Гутников, О. В., 2019].

Автор настоящего исследования выделяет три меры ответственности за невыполнение корпоративных обязанностей. Самой распространенной мерой ответственности в российском праве является исключение участника из корпоращии. Исключение участника коммерческой организации возможно Аишь на основе санкции суда. При этом судебным органом должно быть установцено грубое нарушение участником общества своих обязанностей ${ }^{17}$. Например, суд вправе искАючить участника за невыполнение обязанности участия в принятии корпоративных решений, если 1) участник систематически уклоняется от участия в общих собраниях, 2) у него не имеется уважительных причин неявки, 3) данные действия наносят существенный вред обществу и (или) делают его деятель-

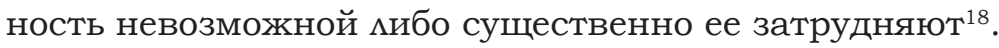

15 Устав Общероссийской общественной организации «Союз машиностроителей России». URL: https:/ / soyuzmash.ru/upload/iblock/1fa/1fa47776f05eb3d9ef2760 88145f1583.pdf (дата обращения: 30.05.2020).

16 Устав Саморегулируемой организации "Союз менеджеров и арбитражных управляющих". URL: http://www.srosoyuz.ru/engine/documents/document1568. pdf (дата обращения: 30.05.2020).

17 См., например: Постановление Первого арбитражного апемляционного суда от 26 января 2018 г. № 01АП-10076/2017 по дему № А43-22340. Доступ из справочной правовой системы «КонсультантПлюс» (дата обращения: 25.05.2020).

18 См.: Постановление Пленума Верховного Суда Российской Федерации от 23 июня 2015 г. № 25 "О применении судами некоторых положений раздема I части первой Гражданского кодекса Российской Федерации». Доступ из справочной правовой системы «КонсультантПлюс» (дата обращения: 25.05.2020). 
В некоммерческих организациях исключение возможно и на основании санкции специального органа корпорации. Так, участника саморегумируемой организации вправе исключить на основании решения органа по рассмотрению дец о применении в отношении членов саморегулируемой организации мер дисциплинарного воздействия.

Во многих зарубежных юрисдикциях другие участники корпораций с ограниченной ответственностью вправе исключить участника на основе резолюции общего собрания ${ }^{19}$. Так, в Германии мажоритарный акционер $\mathrm{GmbH}$ вправе искцючить миноритарного участника, если он действует не в интересах корпорации, и это позволит нивелировать корпоративный конфмикт ${ }^{20}$. При этом суд не удовцетворит иск об исключении, пока не имеется санкции общего собрания [Кузнецов, А. А., 2012].

Другой мерой ответственности за невыполнение обязатемьств явцяется приостановление права голоса на общем собрании (suspension of the exercise of voting rights). Данная мера ответственности не всегда связана с невыполнением корпоративных обязанностей. Например, голос участника может не учитываться при голосовании по одобрению сделки, где он имеет аффимированность с контрагентом. Тем самым во главу угла ставятся интересы корпорации, а не конкретного акционера. Аибо участник может мишаться права голоса по акциям, если они находятся в общей собственности и собственники не выбрали представителя дия реализации права голоса по ним ${ }^{21}$. В качестве санкции право голоса может приостанавциваться за неисполнение обязанности по оплате акции до момента фактической опматы ${ }^{22}$ или за невыполнение обязанности по обязательному направлению предложения о приобретении акций другим акционерам ${ }^{23}$. В Бразилии право голоса может приостанавциваться до тех пор, пока участник общества не выполнит определенную обязанность [Marques, P. D. S., 2020].

Третьей мерой ответственности выступают финансовые санжиии в отношении участника. Данная мера ответственности может включаться в

19 How to exclude the shareholder of a company in Spain // Mariscal \& Abogados, S.L.P. URL: https://www.mariscal-abogados.com/how-to-exclude-the-shareholderof-a-company-in-spain/ (дата обращения 01.07.2020).

20 Exclusion of a Shareholder from a Two-Member GmbH. Friedrich Graf von Westphalen \& Partner mbB. URL: https://www.fgvw.de/en/news/archive-2016/exclusion-of-ashareholder-from-a-two-member-gmbh (дата обращения 01.07.2020).

21 Shareholder Rights. Galapagos NV. URL: https://www.glpg.com/shareholder-rights (дата обращения: 01.07.2020).

22 Shareholder Rights. Galapagos NV. URL: https://www.glpg.com/shareholder-rights (дата обращения: 01.07.2020).

23 См. п. 6 ст. 84.2 Федерального закона от 26 декабря 1995 г. № 208-Ф3 (ред. от 31 июля 2020 г.) "Об акционерных обществах". Доступ из справочной правовой системы «КонсультантПцюс» (дата обращения: 25.05.2020). 
корпоративный договор, устав или содержаться в положениях национального законодательства. Финансовые санкции могут выражаться в

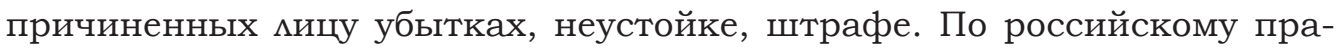
ву ответственность в основном несут участники, контролирующие деятельность корпорации. Именно к ним в случае причинения принятым решением корпорации убытков вправе обратиться с иском само юридическое мицо или его участники. Анализ судебной практики показывает, что с других участников корпорации преимущественно взыскиваются убытки.

Примером применения финансовых санкиий в отношении акиионера может служить корпоративный иск компании "Роснефрть" к ПАО "АФК Система" о взыскании убытков, причиненных в результате реорганизаиии "Башнефти", где суд пришел к выводу о взыскании убытков на основе норм как корпоративного права, так и деликтного ${ }^{24}$. Бенефиииаром при взыскании денежных средств выступает корпораиия, а не ее участники. Хотя в судебной практике встречаются и иные случаи, например, когда юридическое лиио бъло ликвидировано ${ }^{25}$.

Разновидностью финансовой санкции явцяется штраф, который применяется в некоммерческих корпорациях. Например, орган саморегулируемой организации по рассмотрению дем о применении в отношении членов саморегулируемой организации мер дисциплинарного воздействия вправе наложить на члена саморегулируемой организации штраф. При этом штраф является не только мерой корпоративной ответственности, но и мерой дисциплинарной ответственности. Порядок наложения штрафра, его размер и виды нарушений, за которые он подмежит взиманию, должны определяться корпоративными документами. Нарушение данных актов вцечет незаконность штрафа ${ }^{26}$.

\section{Обсуждение и закАючение}

В результате исследования можно сдемать следующие выводы.

1. Обязанности участников подраздемяются на основные и дополнительные.

24 См., например: Постановцение Восемнадцатого арбитражного апемцяционного суда от 25 декабря 2017 г. № 18АП-12317/2017 по дему № А07-14085/2017. Доступ из справочной правовой системы “КонсультантПцюс» (дата обращения: 25.05.2020).

25 Определение Верховного Суда Российской Федерации от 5 февраля 2018 г. № 307-ЭС 17-21779 по деку № А56-59760/2014. Доступ из справочной правовой системы «КонсультантПцюс» (дата обращения: 25.05.2020).

26 См., например: Постановцение Второго арбитражного апемляционного суда от 13 июля 2016 г. № 02АП-2876/2016 по дему № А82-15561/2015. Доступ из справочной правовой системы «КонсультантПлюс» (дата обращения: 23.07.2020).

Правосудие/Justice. T. 3, № 1. 2021. Оригинальные статьи 
2. Основными обязанностями участников корпорации выступают следующие: не допускать змоупотребления корпоративными правами, действовать добросовестно, участвовать в образовании имущества корпорации, не разглашать конфиденциальную информацию о деятельности корпорации, заблаговременно уведомлять корпорацию и ее участников о намерении обратиться с косвенным иском, раскрывать информацию.

3. Обязанность действовать добросовестно и обязанность не допускать действий, направленных на змоупотребление правом, по своему содержанию разцичаются.

4. Фидуциарная обязанность участников корпорации фактически приравнивается к обязанности действовать добросовестно.

5. Применяются следующие меры корпоративной ответственности за неисполнение обязанностей: исключение участника из корпорации, приостановцение права голоса, финансовые санкции.

\section{Список используемой митературы}

Асосков А. В., Байбак В. В., Бевзенко Р. С. и др. Основные положения гражданского права: постатейный комментарий к статьям 1-16.1 Гражданского кодекса Российской Федерации [Эмектрон-

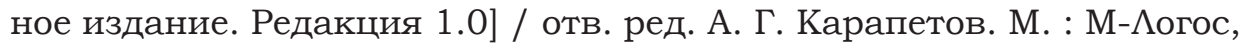
2020. 1469 c.

Бадулина Е. В., Беляев К. П., Васильев А. С. и др. Гражданский кодекс Российской Федерации. Юридические мица: постатейный комментарий к главе 4 / под ред. П. В. Крашенинникова. М. : Статут, 2014. 524 c.

Гутников О. В. Исключение участника юридического мица: мера ответственности и способ защиты корпоративных прав // Вестник экономического правосудия Российской Федерации. 2015. № 2. C. $102-127$.

Гутников О. В. Корпоративная ответственность в гражданском праве : моногр. М. : ИЗиСП, 2019. 488 с.

Кузнецов А. А. Исключение участника из общества с ограниченной ответственностью: теоретическая конструкция и вопросы практики применения // Вестник гражданского права. 2012. № 5. С. 94-137. Нам К. В. Принцип добросовестности: развитие, система, проблемы теории и практики. М. : Статут, 2019. 278 с.

Новак Д. В. Добросовестность в корпоративном праве // Вестник гражданского права. 2017. № 2. С. 13-23.

Смирнова Я. А. Зцоупотребления корпоративными правами участниками хозяйственных обществ : дис. ... канд. юрид. наук. М., 2019. 246 c. 
Смирнова Я. А. Фидуциарные обязанности участников корпорации // Законодательство. 2018. № 4. С. 34-41.

Anabtawi I., Stout L. Fiduciary Duties for Activist Shareholders / / Stanford Law Review. 2008. Vol. 60, no. 5. P. 1255-1308.

Armour J. Shareholder rights // Oxford Review of Economic Policy. 2020. Vol. 36, issue 2. P. 314-340. DOI: 10.1093/oxrep/graa005.

Bratina B., Jovanovič D. Shareholders' Duty of Loyalty and Positive Voting Duty / / China-USA Business Review. 2014. Vol. 13, no. 5. Pp. 347355. DOI: 10.17265/1537-1514/2014.05.006.

Cahn A. The Shareholders' Fiduciary Duty in German Company Law / / Shareholders' Duties / ed. H. S. Birkmose. Kluwer Law International, 2017. URL: https://ssrn.com/abstract=3126695 (дата обращения: 07.07.2020).

Conac P. The Shareholders' Duty Not to Abuse Rights // Shareholders' Duties / ed. H. S. Birkmose. Kluwer Law International, 2017. URL: https://ssrn.com/abstract=3123001 (дата обращения: 07.07.2020).

De Jongh M. Shareholders' Duties to the Company and Fellow Shareholders // European Company Law. 2012. Vol. 9. P. 185-191. URL: https://ssrn.com/abstract=1929745 (дата обращения: 01.07.2020).

Enforcing Shareholders' Duties. Series: Elgar financial law / eds. H. S. Birkmose, K. Sergakis. Glasgow: Edward Elgar, 2019. 320 p.

Grantham R. The Doctrinal Basis of the Rights of Company Shareholders // The Cambridge Law Journal. 1998. Vol. 57, no. 3. P. 554-588.

Encyclopedia of Corporate Social Responsibility / eds. S. O. Idowu, N. Capaldi, L. Zu, A. Das Gupta. Springer, 2013. 2772 p.

Marques P. D. S. Book Review: Enforcing Shareholders' Duties // Social \& Legal Studies. 2020. URL: https://doi.org/10.1177/0964663920 914964. DOI: 10.1177/0964663920914964.

Ponta A. Good faith in corporate law - an independent fiduciary duty or an element of the duty of loyalty? / / Juridical Tribune (Tribuna Juridica). Bucharest Academy of Economic Studies. Law Department. 2016. Vol. 6. P. 117-133.

Søndergaard B., Möslein F. Introduction: Mapping Shareholders' Duties // Shareholders' Duties / ed. H. S. Birkmose. Kluwer Law International, 2017. URL: https://ssrn.com/abstract=3122380 (дата обращения: 30.06.2020).

Sørensen K. E., Shareholders' Duty to Disclose / / Shareholders' Duties / ed. H. S. Birkmose. Kluwer Law International, 2017. URL: https:// ssrn.com/abstract=3122386 (дата обращения 20.05.2020).

Varottil U. Minority Shareholders' Rights, Powers and Duties: The Market for Corporate Influence // Research Handbook on Comparative 
Corporate Governance / eds. A. Afsharipour, M. Gelter. Edward Elgar Publishing, 2020. URL: https://ssrn.com/abstract=3543246 (дата обращения 15.06.2020).

\section{References}

Anabtawi, I. and Stout, L., 2008. Fiduciary Duties for Activist Shareholders. Stanford Law Review, 60(5), pp. 1255-1308.

Armour, J., 2020. Shareholder rights. Oxford Review of Economic Policy, 36(2), pp. 314-340. DOI:10.1093/oxrep/graa005.

Asoskov, A. V., Baybak, V. V., Bevzenko, R. S., et al., 2020. Osnounye polozheniya grazhdanskogo prava: postateynyy kommentariy $k$ stat' yam 1-16.1 Grazhdanskogo kodeksa Rossijskoy Federatsii = [The main Provisions of Civil Law: Article-by-article Commentary to Articles 1-6.1 of the Civil Code of the Russian Federation]. Ed. A. G. Karapetov. Moscow: M-Logos. (In Russ.)

Badulina, E. V., Belyaev, K. P., Vasil'ev A. S., et al., 2014. Grazhdanskiy kodeks Rossiyskoy Federatsii. Yuridicheskie litsa: postateynyy kommentariy $k$ glave $4=$ [Civil Code of the Russian Federation. Legal Entities: Article-by-article Commentary to Chapter 4]. Ed. P. V. Krasheninnikov. Moscow: Statut. (In Russ.)

Birkmose, H. S. and Sergakis, K., eds., 2019. Enforcing Shareholders' Duties. Series: Elgar financial law. Glasgow: Edward Elgar.

Bratina, B. and Jovanovič, D., 2014. Shareholders' Duty of Loyalty and Positive Voting Duty. China-USA Business Review, 13(5), pp. 347-355. DOI: 10.17265/1537-1514/2014.05.006.

Cahn, A., 2017. The Shareholders' Fiduciary Duty in German Company Law. In: H. S. Birkmose, ed. Shareholders' Duties. Kluwer Law International. Available at: <https://ssrn.com/abstract=3126695> [Accessed 07 June 2020].

Conac, P., 2017. The Shareholders' Duty Not to Abuse Rights. In: H. S. Birkmose, ed. Shareholders' Duties. Kluwer Law International. Available at: <http://dx.doi.org/10.2139/ssrn.3123001> [Accessed 7 June 2020].

De Jongh, M., 2012. Shareholders' Duties to the Company and Fellow Shareholders. European Company Law, 9, pp. 185-191. Available at: <http://dx.doi.org/10.2139/ssrn.1929745> [Accessed 1 July 2020].

Grantham, R., 1998. The Doctrinal Basis of the Rights of Company Shareholders. The Cambridge Law Journal, 57(3), pp. 554-588.

Gutnikov, O. V., 2015. [Exclusion of a Participant in a Legal Entity: a Measure of Responsibility and a Method of Protecting Corporate Rights]. Vestnik ekonomicheskogo pravosudiya Rossijskoj Federacii $=[$ Bulletin of Economic Justice of the Russian Federation], 2, pp. 102-127. (In Russ.) 
Gutnikov, O. V., 2019. Korporativnaya otvetstvennost'v grazhdanskom prave $=$ [Corporate Responsibility in Civil Law]. Monograph. Moscow: IZiSP. (In Russ.)

Idowu, S. O., Capaldi, N., Zu, L. and Das Gupta, A., eds., 2013. Encyclopedia of Corporate Social Responsibility. Springer.

Kuznetsov, A. A.. 2012. [Exclusion of a Shareholder From a Limited Liability Company: Theoretical Construction and Practical Application Issues]. Vestnik grazhdanskogo prava = [Bulletin of Civil Law], 5, pp. 94137. (In Russ.)

Marques, P. D. S., 2020. Book Review: Enforcing Shareholders' Duties. Social \& Legal Studies. Available at: <https://doi. org/10.1177/0964663920914964> [Accessed 1 July 2020]. DOI: $10.1177 / 0964663920914964$.

Nam, K. V., 2019. Printsip dobrosovestnosti: razvitie, sistema, problemy teorii $i$ praktiki $=$ [The Principle of Conscientiousness: Development, System, Problems of Theory and Practice]. Moscow: Statut. (In Russ.)

Novak, D. V. 2017. [Conscientiousness in corporate law]. Vestnik grazhdanskogo prava = [Bulletin of Civil Law], 2, pp. 13-23 (In Russ.)

Ponta, A., 2016. Good faith in corporate law - an independent fiduciary duty or an element of the duty of loyalty? Juridical Tribune (Tribuna Juridica). Bucharest Academy of Economic Studies, Law Department, 6, pp. 117-133.

Smirnova, Ya. A., 2018. [Fiduciary duties of corporation members]. Zakonodatel'stvo $=$ [Legislation], 4, pp. 34-41. (In Russ.)

Smirnova, Ya. A., 2019. Zloupotrebleniya korporativnymi pravami uchastnikami khozyaystvennykh obshchestv $=$ [Abuse of Corporate Rights by Members in Business Entities]. Cand. Sci. (Law) Dissertation. Moscow. (In Russ.)

Søndergaard, B. and Möslein, F. 2017. Introduction: Mapping Shareholders' Duties. In: H. S. Birkmose, ed. Shareholders' Duties. Kluwer Law International. Available at: <https://ssrn.com/abstract=3122380> [Accessed 30 June 2020].

Sørensen, K. E., 2017. Shareholders' Duty to Disclose. In: H. S. Birkmose, ed. Shareholders' Duties. Kluwer Law International. Available at: <https://ssrn.com/abstract=3122386> [Accessed 20 May 2020].

Varottil, U., 2020. Minority Shareholders' Rights, Powers and Duties: The Market for Corporate Influence. In: A. Afsharipour and M. Gelter, eds. Research Handbook on Comparative Corporate Governance. Edward Elgar Publishing. Available at: <https://ssrn.com/abstract $=3543246>$ [Accessed 15 June 2020]. DOI: 10.2139/ssrn.3543246. 


\section{Информация об авторе / Information about the author}

Грибов Николай Дмитриевич, кандидат юридических наук, доцент кафедры гражданского и административного судопроизводства ФГБОУВО "Российский государственный университет правосудия" (Российская Федерация, 117418, г. Москва, ум. Новочеремушкинская, д. 69)

Nick D. Gribov, Cand. Sci. (Law), Associate Professor of the Civil and Administrative Proceedings Department (69 Novocheremushkinskaya St., Moscow, 117418, Russian Federation).

E-mail: ng.law@yandex.ru

Дата поступления рукописи в редакцию издания: 28.09.2020; дата одобрения после рецензирования: 05.10.2020; дата принятия статьи к опубмикованию: 02.02.2021.

Submitted 28.09.2020; reviewed 05.10.2020; revised 02.02.2021. 
УДК 34.01

DOI: $10.37399 / 2686-9241.2021 .1 .148-183$

\title{
Криминалистические базы данных геномной информации: международный опыт и возможность его применения в Российской Федерации
}

\author{
А. Г. Семиходский \\ ООО «Медикал Геномикс», г. Тверь, Российская Федерация \\ andrei@medicalgenomics.ru
}

\begin{abstract}
Аннотация
Введение. В статье освещаются актуальные вопросы создания и использования федеральной базы геномной информации Российской Федерации. Несмотря на то что экспертное применение криминалистического анализа ДНК началось еще в конце 80-х - начале 90-х гг. XX столетия, законодательная основа использования ДНК для расследования преступлений не соответствует требованиям, предъявляемым сегодня.

Теоретические основы. Методы. Проведенное исследование базируется на сравнительном анализе нормативно-правовых основ криминалистических баз генетических данных зарубежных стран, в особенности Соединенного Королевства и США, и Российской Федерации.

Результаты исследования. Основываясь на опыте стран, где созданы и эффективно применяются криминалистические базы данных ДНК, обсуждается правовое регулирование подобного рода баз и целей, для которых они используются. Обсуждаются виды преступлений, субъекты которых подлежат генетической регистрации, и процессуальная категория лиц, у которой берутся образцы ДНК. Рассматриваются сроки хранения и критерии удаления генетической информации. Отдельно разбираются вопросы контроля качества и этического использования генетической информации для целей раскрытия преступлений.

Обсуждение и заключение. Отмечена необходимость законодательных инициатив, которые позволят правоохранительным органам иметь базу геномной информации в качестве эфффективного инструмента для борьбы с преступностью.
\end{abstract}

Ключевые слова: база данных геномной информации, база данных ДНК, криминалистическая база данных ДНК, генетическая база данных, ДНК-криминалистика, криминалистический анализ ДНК, криминалистическая генетика

Для цитирования: Семиходский А. Г. Криминалистические базы данных геномной информации: международный опыт и возможность его применения в Российской Федерации // Правосудие/Justice. 2021. T. 3, № 1. C. 148-183. DOI: 10.37399/26869241.2021.1.148-183. 


\title{
Forensic DNA Databases: International Experience and the Possibility of its Application in the Russian Federation
}

\author{
Andrei G. Semikhodskii \\ Medical Genomics LLC, Tver', Russian Federation \\ For correspondence: andrei@medicalgenomics.ru
}

\begin{abstract}
Introduction. The article highlights a number of topical issues involving the federal database of genomic information of the Russian Federation. Despite the fact that the expert application of forensic DNA analysis began in the late 80 s/early 90 s of the twentieth century, the legal basis for the use of DNA for crime investigation does not meet the requirements of today.

Theoretical Basis. Methods. The study is based on a comparative analysis of the legal framework of forensic genetic databases of foreign countries, especially the United Kingdom and the United States, and the Russian Federation.

Results. Based on the experience of countries where forensic DNA databases have been created and are effectively used, the general legislative principles of organizing such databases are discussed. Crimes warranting genetic registration and the procedural category of persons from whom DNA samples should be taken for the database purposes are considered as well as the length of the retention period and criteria for deleting genetic information. The issues of quality control and ethical use of genetic information for solving crimes are discussed separately. In conclusion, the need for a legislative initiative that will allow law enforcement agencies to have a genomic information database as an effective tool for combating crime is proposed.

Discussion and Conclusion. The paper emphasises a need for legislative initiatives that would allow law enforcement agencies to have a genomic database as an effective tool for combating crime.
\end{abstract}

Keywords: genomic information database, DNA database, DNA forensic database, genetic database, DNA forensics, DNA forensic analysis, forensic genetics

For citation: Semikhodskii, A. G., 2021. Forensic DNA databases: International experience and the possibility of its application in the Russian Federation. Pravosudie/Justice, 3(1), pp. 148-183. DOI: 10.37399/2686-9241.2021.1.148-183.

\section{Введение}

\section{Криминалистические базы данных ДНк в мире и в России}

Дезоксирибонуклеиновая кислота (ДНК) была открыта в 1869 г. швейцарским ученым Иоганном Фридрихом Мишером (Johannes Friedrich Miescher). На протяжении многих мет биологическая функция ДНК была не ясна. Еще в начале XX столетия, когда генетика уже сформировалась как отдельная наука, многие ученые были уверены, что ДНК не имеет никакого отношения к передаче наследственной информации.

Прошло не одно десятиметие, прежде чем в 40-х гг. XX в. было доказано, что именно ДНК явцяется носителем генетической информации. В 1953 году англичанин Френсис Крик (Francis Crick) вместе с американцем Джеймсом Уотсоном (James Watson) установили, что структура ДНК представляет собою двойную антипараллельную спираль, тем самым не 
только положив начало современной молекулярной биологии, но и осуществив прорыв в развитии медицины, семьского хозяйства и криминалистики.

Возможность использования ДНК с целью идентификации человека

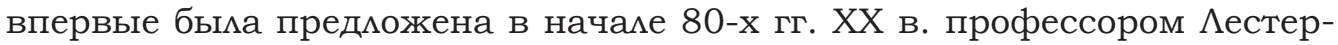
ского университета в Соединенном Королевстве Алеком Джеффрисом (Alec Jeffreys), который обнаружиц, что, несмотря на то что ДНК всех дей более чем на 99 \% идентична, в ней имеются участки, отличающиеся у разных мюдей. Анализ этих участков позволяет практически однозначно идентифицировать человека по его биологическому материалу. Сейчас ДНК-анализ используется не только в криминалистике, где этот метод стац основным методом идентификации чемовека, но и дмя установцения отцовства и других видов родства и даже этнического происхождения.

Важность учета генетической информации была признана сразу, как только генетический анализ начал использоваться правоохранитецьными органами. За идеей создания криминалистических баз данных ДНК стоит намерение, с одной стороны, сдемать полицию более оперативной, эффективной и организованной, а с другой стороны - уменьшить комичество ошибок при отправлении правосудия. Национальная криминалистическая база генетической информации позволяет не только раскрыть преступления, которые не могли бы быть раскрыты без ее использования, но также значимо сократить затраты и время раскрытия преступлений. Опыт использования британской национальной криминалистической базы данных ДНК показывает среднее увеличение раскрываемости на 60\% ${ }^{1}$ и повышение раскрываемости нетяжких преступлений в 3-4 раза ${ }^{2}$. Немаловажным является использование баз данных для обмена генети-

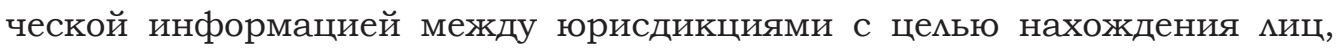
скрывающихся от правосудия.

Первая в мире база генетической информации ${ }^{3}$ для целей предупреждения и раскрытия преступлений была создана в Соединенном Коромевстве в 1995 г. и получила название NDNAD (от англ. National DNA Database - национальная база данных ДНК).

Вскоре аналогичные базы данных были созданы в других европейских государствах и в США. На сегодняшний день в 69 странах мира

Подробно о создании и использовании NDNAD см.: [Semikhodskii, A., 2007].

2 National DNA Database Strategy Board Annual Report 2017/18 (2019). URL: https: / www.gov.uk/government/ publications / national-dna-database-annualreport-2017-to-2018 (дата обращения: 30.06.2020).

3 В мировой митературе криминалистические базы генетической информации наиболее часто называют "криминалистическая база данных ДНК" или "криминалистическая база генетических данных". Подобная терминология будет использована в настоящей статье.

Правосудие/Justice. Т. 3, № 1. 2021. Оригинальные статьи 
уже используются криминалистические базы ДНК, а в 34 странах базы находятся на разных стадиях разработки [Machado, H. and Granja, R., 2020]. Д. Чалмерз [Chalmers, D., 2005] и Ф. Сантос с комлегами [Santos, F., Machado, H. and Silva, S., 2013] дают всесторонний анализ ситуации в Европе и некоторых других странах. Национальная база данных ДНК США CODIS (от англ. Combined DNA Index System - единая система ДНКиндексации) и базы данных ДНК отдемьных штатов описаны Д. Херкенхэмом [Herkenham, D., 2002].

Собственную автоматизированную базу генетических данных - DNA Gateway (от англ. ДНК-портац), содержащую профими ДНК, представменные странами-членами, имеет Интерпол. DNA Gateway была создана в 2002 г. и содержит более 242000 профилей ДНК из 85 стран-членов ${ }^{4}$. В отмичие от других баз DNA Gateway используется только дия сравнения и обмена информацией и не позволяет идентифицировать конкретного

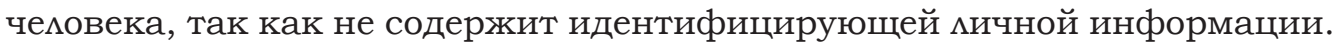
Она функционирует как автономная база данных и не связана с другими базами данных Интерпома.

\section{Теоретические основы. Методы}

Дия проведения исследования был сдеман сравнитемьный анализ состояния криминалистических баз генетических данных в разных странах и регламентирующего их работу законодательства. Было проанализировано текущее состояние российского законодательства в области использования ДНК-криминалистики и сделано сравнение со странами, наиболее активно использующими генетическую информацию дмя раскрытия преступлений, в частности Соединенным Королевством и США.

\section{Резумьтаты иссиедования}

Многолетнее использование генетических баз данных правоохранительными органами опредемимо функции, которые они выполняют на сегодняшний день:

- базы данных являются репозиторием генетической информации;

- базы данных позволяют связать между собой разные эпизоды преступцения внутри одного уголовного дела, преступления, совершенные с разницей во времени;

- базы данных позволяют идентифицировать предполагаемого преступника, жертву преступления ими неопознанный труп внутри собственной юрисдикции;

- базы данных позволяют идентифицировать предполагаемого преступника, жертву преступления или неопознанный труп в других юрисдикциях;

4 Интерпол. URL: https://www.interpol.int/en/How-we-work/Forensics/DNA (дата обращения: 07.11.2020). 
- базы данных позволяют раскрывать преступления, совершенные многие годы назад;

- базы данных являются средством сдерживания дмя потенциального правонарушителя.

В странах, где полицейские службы начали использовать ДНК-методы идентификации и созданы криминалистические базы генетической информации, появицось новое законодательство и были внесены соответствующие изменения в уже существующее. Таким образом, была создана система правового регулирования не только баз данных подобного рода, но и использования генетической идентификации правоохранительными органами в целом. Законодательно стали регулироваться категория преступлений, подлежащих регистрации, возможность применения физического принуждения при изъятии образцов, а так же тип биологического материала (образцы), изымаемого у субъекта. Учитывая особенности генетической информации, ее высокую доказательную ценность и возможность использования данных для целей, не связанных с раскрытием преступлений, были установлены сроки хранения и критерии удаления генетической информации, опредемены санкции за ее нецелевое использование и несанкционированный доступ к ней и регламентированы другие аспекты использования ДНК полицейскими службами. В настоящее время специальное законодатемьство, регулирующее деятельность баз генетических данных и использования ДНК-анализа, действует во всех странах Европейского Союза (ЕС), Соединенном Королевстве, США, Канаде, Австралии, Республике Корея, Малайзии и многих других странах.

В России экспертное применение криминалистического анализа ДНК началось еще в советский период, в конце 80-х - начале 90-х гг. прошлого столетия, однако первый акт - Федеральный закон № 242-Ф3 «О государственной геномной регистрации в Российской Федерации" 5 , регули-

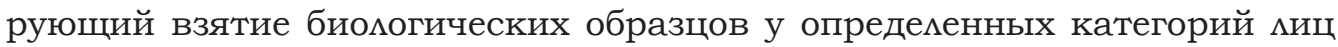
и неопознанных трупов и порядок хранения генетической информаций,

5 Федеральный закон от 3 декабря 2008 г. № 242-Ф3 “О государственной геномной регистрации в Российской Федерации" (с изм. от 17.12.2009). URL: http://docs. cntd.ru/document/902131995 (дата обращения: 02.11.2020).

6 Геном - это полный набор ДНК человека (около 3,5 млрд пар нуклеотидных оснований). Геномная информация - это информация об очень большом количестве ДНК-маркеров, как правимо, исчисляемых сотнями тысяч или мимлионами, полученная, в результате широкомасштабного секвенирования или при помощи ДНК-микрочипов высокой плотности. Геномные данные вкцючают в себя большие массивы данных, которые можно использовать в разных целях, например для диагностики или установления предрасположенности к заболеваниям, для целей персонализированной медицины, для нахождения дальних родственников или же установления этнического происхождения и т. д. В отличие от геномных, генетические данные - это, как правило, информация о гораздо меньшем количестве ДНК-маркеров. Количество всех генетических маркеров, использу- 
появился только в 2008 г. В митературе [Перепечина, И. О., 2010; Попова, Т. В. и Сергеев, А. Б., 2017] обращалось внимание на несовершенство этого Закона: в нем не предусмотрены ни геномная регистрация подозреваемых и миц, против которых выдвинуто обвинение в совершении преступления, ни генетическая регистрация в ходе производства след-

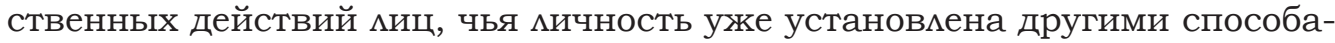
ми; не предполагается регистрация генетической информации, полученной из биологических пятен с объектов, изъятых на месте преступления. Законом нечетко определены критерии хранения и удаления генетической информации, не оговорена судьба генетической информации субъекта, когда, по результатам генетической экспертизы, он не имеет отношения к совершению расследуемого преступления, не оговорены типы биологических образцов, отбираемых у субъектов, возможность отказа

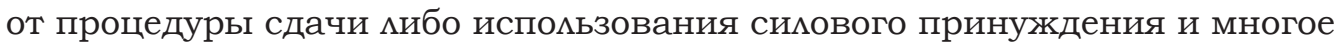
другое. Все это свидетельствует о необходимости разработки специального правового регулирования работы базы данных геномной информации, использования ДНК-экспертизы дмя расследования преступлений.

В 2006 году МВД России в рамках экспертно-криминалистического учета данных ДНК биологических объектов создало первую в Российской Федерации базу генетических данных ${ }^{7}$. Спустя два года Федеральный закон № 242-Ф3 “О государственной геномной регистрации в Российской Федерации" заложил основы геномной регистрации в стране, и в 2009 г. была создана Федеральная база данных геномной информации (ФБДГИ). По данным МВД России, на 2017 г. ФБДГИ содержала геномную информацию всего 0,14\% насемения страны [Гостев, А. А., 2017].

Еще одна криминалистическая база генетической информации - «Единый ДНК-учет Следственного комитета" была создана в Криминалистическом центре Следственного комитета Российской Федерации в 2019 г. На конец 2019 г. на учете в реестре стояно 31988 генетических профимей проверяемых $\Lambda и ц^{8}$.

Несовершенство законодательного регулирования не позволяет эффективно использовать ФБДГИ дмя правоохранительных целей, а использование ДНК-базы СКР вызывает вопросы не только о ее правовой основе,

емых в криминалистике, меньше 50, и термин "генетическая", а не "геномная" более правильно отражает тип данной информации. Четких стандартов применения терминов "геномная информация" и "генетическая информация" не существует, и эти термины часто взаимозаменяемы.

7 Приказ МВД России от 10 февраля 2006 г. № 70 «Об организации использования экспертно-криминалистических учетов органов внутренних дем Российской Федерации". URL: http://docs.cntd.ru/document/901969840 (дата обращения: 21.08.2020).

8 Александр Бастрыкин: «В криминалистическом центре СКР создан банк ДНКданных" / / Российская газета. 2019. 15 окт. 
но и о законности полученных с ее помощью доказательств. Дискуссионными явцяются круг миц, подлежащих регистрации, их процессуальный статус, преступления, по которым домжно производиться изъятие генетических образцов и их регистрация [Белов, О. А. и Белова, О. Н., 2016], а также сроки хранения генетической информации. В связи с этим МВД России и Общественной палатой Российской Федерации в 2016 г. был подготовлен проект закона "О внесении изменений в отдемьные законодательные акты Российской Федерации по вопросам государственной геномной регистрации" ${ }^{9}$ В проекте закона предиагалось расширить круг миц, подлежащих геномной регистрации, вкАючив туда подозреваемых и обвиняемых в совершении преступления, однако до сих пор изменения не приняты законодателем. Такое неудовцетворитецьное состояние дел обусловлено отсутствием законодательных и организационных рамок для создания единой централизованной базы геномной информации в Российской Федерации, которую могми бы использовать все заинтересованные правоохранительные органы. Вместо этого налицо ведомственность (создание баз дия конкретного подраздемения), дополнитемьные затраты бюджетных средств на генотипирование, IT инфраструктуру и поддержание базы данных, что затрудняет испомьзование достижений криминалистической генетики для правоохранитемьных целей.

\section{Цели базы данных геномной информаиии}

Действующее российское законодатемьство определяет цемью государственной геномной регистрации не расследование преступлений, а иден-

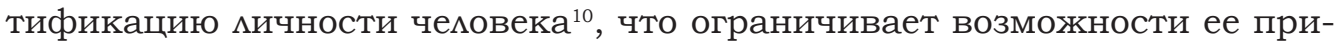
менения.

В ведущих западных странах законодательством четко закреплены цели, для которых можно использовать криминалистические базы генетической информации. В Соединенном Королевстве, например, таковыми явАяются ${ }^{11}$ :

- цели национальной безопасности;

- цели расследования терроризма;

- цели предупреждения и раскрытия преступлений;

- цели расследования правонарушений или уголовного преследования;

- цели идентификации умершего человека.

9 Проект закона "О внесении изменений в отдельные законодательные акты Российской Федерации по вопросам государственной геномной регистрации". URL: https://www.oprf.ru/ru/1449/2133/1537/2192/newsitem/34119 (дата обращения: 21.07.2020).

10 Статья 2 Закона № 242-Ф3.

11 S. 63T Police and Criminal Evidence Act 1984. URL: https://www.legislation.gov. uk/ukpga/1984/60/contents (дата обращения: 21.07.2020) 
Использование базы в других целях запрещено.

При разработке нормативных правовых документов, которые четко установят цели криминалистического учета геномной информации и будут регламентировать деятельность криминалистической базы данных ДНК, российскому законодателю следует учитывать, что включение в базу генетической информации человека в той или иной степени может нарушать ряд прав и свобод, гарантированных ему Всеобщей декларацией прав человека и Конституцией Российской Федерации: право на неприкосновенность частной жизни, честь и достоинство человека, право на Аичную и моральную неприкосновенность, право не свидетельствовать против себя, право на презумпцию невиновности, право на охрану здоровья и право на свободу [Guillén, M., et al., 2000].

\section{Обице принципы организачии криминалистической базы генетической информаиии}

Криминалистическая база данных ДНК, будучи прежде всего компьютеризированным хранилищем информации, должна соответствовать современным стандартам управления данными. Это позволит не только обеспечить ее эффективное использование, но и поддерживать долгосрочно качество сохраняемых данных [DAMA International, 2017]. Применительно к генетической базе такими принципами являются:

- понимание и поддержка информационных потребностей всех заинтересованных в использовании базы служб и субъектов, включая физиче-

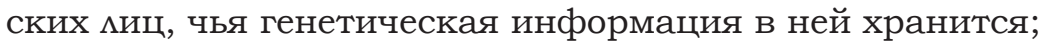

- обеспечение адекватного хранения, защиты и целостности данных;

- создание системы контроля качества загружаемых и хранящихся данных;

- обеспечение конфиденциальности;

- предотвращение несанкционированного или ненадмежащего доступа, манипулирования или использования данных и информации;

- создание системы эффективного использования данных.

Все упомянутые стандарты и принципы нуждаются в нормативном регулировании. Если одни из них, например создание системы контроля качества, могут регламентироваться внутренним стандартом правообладателя базы, то обеспечение конфиденциальности, соблюдение интересов физических миц, чьи данные хранятся в базе, доступ к базе разных структур охраны общественного порядка и обеспечения национальной безопасности необходимо регулировать на уровне закона. Рассмотрим эти важные вопросы.

Данные - это информация, хранящаяся в цифровом виде, имеющая свои характеристики и особенности, жизненный цикл и другие параметры, которые не только необходимо учитывать при создании генетического репозитория, но и некоторые из них регламентировать законода- 
темьно. Генетическая информаиия - это особый тип данных, обладающий уникальными свойствами: наиболее очевидными явцяются неизменность генетической информации на протяжении всей жизни человека, ее наследуемость и многоплановость использования. Она позволяет не только практически однозначно идентифицировать человека, но и установить родственные связи между мюдьми.

Нормативное регулирование системы управления базы генетических данных домжно учитывать их жизненный цикА, который может быть очень сложным. Развитие молекулярно-генетических технологий со временем приводит как к увеличению числа параметров уже используемого типа данных, характеризующих образец, так и к появмению новых типов генетических данных ${ }^{12}$. Изменения в общественном мнении и решения судебных инстанций могут сдемать необходимым включение в базу информации об опредеменной категории субъектов, удаление какой-то части данных ими изменение сроков их хранения ${ }^{13}$.

Законодательно домжны быть установлены типы генетической информации, которую как можно получать от субъекта и хранить в базе данных, так и получение которой незаконно. Важным критерием выбора типа хранящихся данных явцяется обеспечение соответствия данных цемям базы данных и задачам, предъявцяемым заинтересованными правоохранительными организациями. Анализ ДНК может дать разнообразную информацию о доноре образца - от информации о наличии или предрасположенности к заболеваниям до информации о цвете кожи, волос, форме носа, возрасте и т. д. [Schneider, P. M., Prainsack, B. and Kayser, M., 2019]. Для расследования преступлений генетические данные домжны обладать высокой дискриминационной способностью и наиболее точно идентифицировать человека. Слишком большое количество информации может быть контрпродуктивно, а включение некоторых видов информации (например, о предрасположенности к заболеваниям) - даже нарушать права человека. Кроме этого, регулирование системы управления данными должно быть нацелено на минимизацию рисков (утрата или повреждение данных и т. п.) и соблюдение этических норм использования хранящейся в базе информации.

12 Это видно на примере NDNAD. На момент создания базы данных в 1995 г. образец ДНК характеризировался по 7 маркерам, с 2014 г. - по 17.

13 Решение Европейского Суда по правам человека в деле S and Marper v United Kingdom [2008] ECHR 1581 обязало Соединенное Королевство удалить из NDNAD

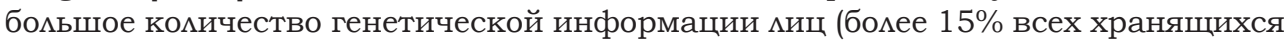
ДНК-профилей субъектов), против которых не было вынесено обвинение или которые не были признаны виновными в совершении преступления. Были также изменены сроки хранения информации в зависимости от процессуального статуса субъекта, его возраста и категории преступления. Результатом этого решения Европейского Суда по правам человека стало принятие Соединенным Коромевством в 2012 г. Закона о защите свобод (Protection of Freedoms Act 2012). 


\section{Типы базы данных}

Генетические базы данных могут быть двух типов - универсальные (всеобщие) и выборочные. Всеобщая база данных включает биоматериал всех ^юдей в стране, или конкретной юрисдикции. Выборочные базы данных содержат информацию об определенной выборке из общего населения по заранее заданным критериям. Дия медико-генетических баз таковыми могут быть наличие какого-либо заболевания, генетические варианты или же определенные физиологические и биохимические показатели, а для криминалистических (полицейских) баз - категория преступления, при совершении которого берется биологический материал, процессуальный статус субъекта и т. д.

Концепция создания универсальной криминалистической базы данных ДНК детально рассмотрена Р. Вицьямсоном и П. Джонсоном [Williams, R. and Johnson, P., 2005]. По мнению этих авторов, взятие биоматериала у каждого чмена общества, включая новорожденных детей, обеспечит беспристрастность базы данных. Каждый гражданин страны, еще не сдавший свой биоматериал, должен будет предоставить свой образец, равно как и каждый иммигрант и, возможно, даже турист. Это поднимает существенные нравственные, а также цогистические проблемы, не говоря уже об очень значительных финансовых затратах.

Существует ряд преимуществ взятия биоматериала у каждого чемовека при рождении по сравнению с анализом ДНК только субъектов, связанных с расследованием преступлений. Основным из них явцяется обеспечение равенства и равноправия всех граждан страны при расследовании. Не секрет, что этническое и гендерное распределение популяции миц, находящихся в местах мишения свободы, не отражает этнического и гендерного распределения населения всей страны. В местах заключения находится значительно больше мужчин, чем женщин, а пропорция этнических меньшинств в тюрьмах значительно выше, чем в общей популя-

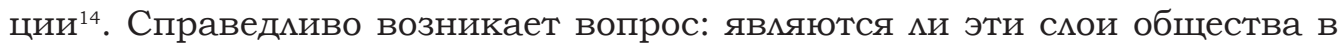
действительности более предрасположенными к активной криминоген-

14 Taк, в британской NDNAD доля ДНK-профилей женщин составляет 19,2\%, а доля ДНК-профимей мужчин - 80,3\% (дмя 0,5\% доноров ДНК пол не установмен). Доля ДНК-профилей от представителей афро-карибской расы составцяет 7,6\% (National DNA Database Strategy Board Annual Report 2017/ 18 (2019). URL: https: / /www.gov.uk/government/ publications / national-dna-database-annualreport-2017-to-2018 (дата обращения: 30.06.2020), тогда как согласно последней переписи населения доля представителей афро-карибской расы среди общего населения Соединенного Королевства составляет только 3,0\% (Office for National Statistics. 2011 Census: Ethnic group, local authorities in the United Kingdom. 11 October 2013. URL: https://web.archive.org/web/20131021150149/http:// www.ons.gov.uk/ons/rel/census/2011-census/key-statistics-and-quick-statisticsfor-local-authorities-in-the-united-kingdom---part-1/rft-ks201uk.xls (дата обращения: 09.11.2020). 
ной деятельности, или же данная ситуация обусловлена наличием других факторов, одним из которых может являться предвзятость правоохранительных органов в отношении определенной социальной, этнической или половой категории граждан? Одним из кАючевых аргументов в поддержку всеобщей генетической идентификации явцяется и то, что взятие образцов у каждого члена общества будет более справедливым, чем сбор образцов только миц, вступивших в тот или иной контакт с системой правоохранительных органов.

Еще одним важным преимуществом универсальной базы являются особенности проведения следственными органами массовых сборов образцов ДНК с цемью исключения миц из числа подозреваемых. Аица, которые по какой-цибо причине отказываются от участия в таком массовом сборе, рискуют оказаться подозреваемыми. По мнению ряда правоведов, массовый сбор образцов может нарушать принцип презумпции невинов-

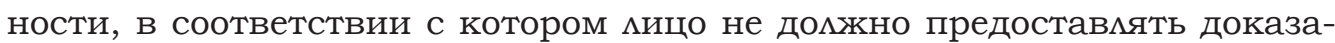
тельства своей невиновности (в данном случае свой образец ДНК) для исключения из числа возможных подозреваемых. Взятие образцов при рождении позволит решить эту проблему.

Взятие биоматериала дмя базы данных ДНК при рождении также может стать значимым фактором сдерживания от совершения правонарушений дмя всех членов общества и одновременно во много раз облегчить процесс идентификации и поимки правонарушителей. Однако дмя этого на законодательном уровне необходимо принять нормы, надежно охраня-

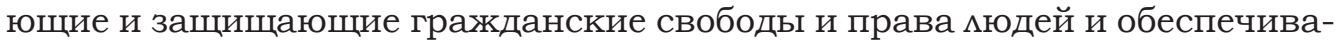
ющие надмежащий контромь за работой такой базы данных.

Попытки создать универсальную криминалистическую базу ДНК предпринимались неоднократно.

В 2005 году правительство Португалии объявило о своем желании внести все свое население в криминалистическую базу данных ДНК. Однако от этого плана отказались из-за опасений по поводу высоких затрат на ее создание и возможных нарушений прав человека. В Соединенном Коромевстве в 2006 г. правительством было предможено создать универсальную базу данных, вкцючающую в себя каждого жителя и посетителя Соединенного Королевства ${ }^{15}$, однако через два года эта идея была отклонена руководителями полицейских службб ${ }^{16}$. Также отказалось от создания универсальной криминалистической базы данных правительство Узбекистана [Wallace, H. M., Jackson, A. R., Gruber, J. and Thibedeau, A. D., 2014].

15 DNA database 'should include all' // The Telegraph. 24 October 2006. URL: http:// www.telegraph.co.uk/news/uknews / 1532210/DNA-database-should-include-all. html (дата обращения: 15.09.2020).

16 Police chiefs against universal DNA database. 27 June 2008. URL: http://rinf.com/ alt-news / surveillance-big-brother/police-chiefs-against-universal-dna-database / (дата обращения: 15.05.2020). 
Многие члены адвокатского корпуса и правозащитные организации разделяют опасение, что база данных, в которую включена генетическая информация всех граждан, может стать основным инструментом вторжения в частную жизнь. На сегодняшний день проблема создания универсальной криминалистической базы генетических данных не решена ни в одном государстве. САишком много этических и технических вопросов нуждаются в проработке, и права и свободы человека домжны быть не только гарантированы de jure, но и обеспечены de facto.

\section{Архитектура базы даннъх}

Архитектура базы данных обусловливает особенности системы доступа к данным, их интеграции и хранения. Из всех известных типов архитектур дия целей создания хранилищ генетической информации важны два типа - централизованная и федеративная (распредеменная) [DAMA International, 2017].

При централизованной архитектуре все данные находятся в одном месте (рис. 1А). В небольших по территории и количеству входящих в них субъектов государствах криминалистические базы данных организованы, как правимо, именно по этому принципу.

A

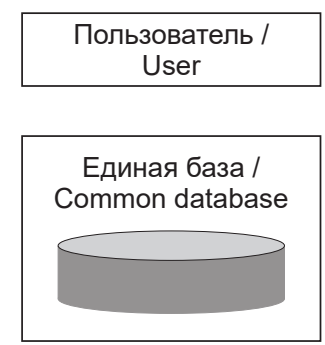

Б
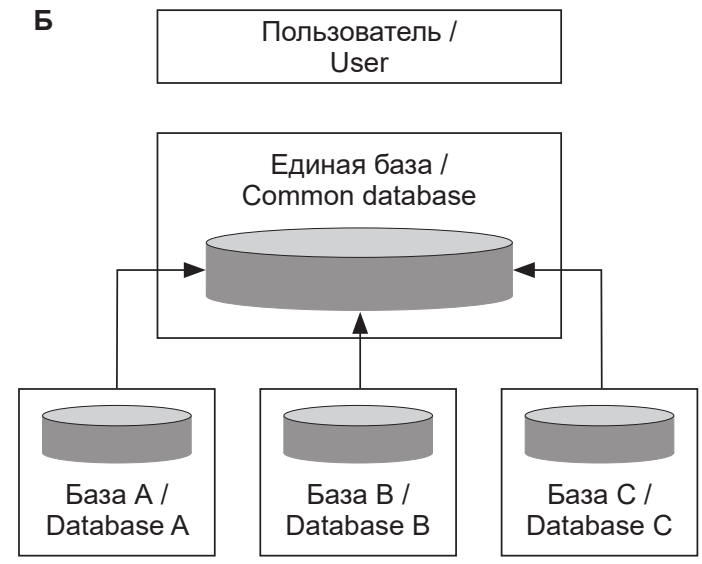

Puc. 1. Типы архитектур баз данных / Pic. 1. Types of database architecture

А. Централизованная база данных / A. Centralised database

Б. Федеративная база данных / В. Federated database

Федеративные базы отмичаются тем, что они состоят из нескоцьких автономных мокальных баз, которые выгружают данные в единую федеративную базу, к которой и имеет доступ помьзователь (рис. 1Б). При федеративной архитектуре составцяющие базы данных часто географически разделены и связаны через компьютерную сеть. Они остаются автоном- 
ными, но экспортируют свои данные (полностью или частично, в зависимости от целей) в единую базу данных. При такой архитектуре фактическая интеграция данных в составцяющих базах данных отсутствует, а осуществцяется непосредственно в единой базе.

Законодателю необходимо решить, будет $\Lambda и$ база данных геномной информации единой (т. е. централизованной), или же региональные экспертные подраздемения будут вначале накапливать генетические данные в своих мокальных базах, а потом с определенной периодичностью выгружать новую информацию в центральную базу (т. е. база будет иметь федеративную архитектуру). Дия государств, состоящих из нескольких юрисдикций, и дмя стран с очень большой территорией федеративная архитектура имеет предпочтение перед централизованной. В Соединенном Королевстве - государстве, вкцючающем три юрисдикции, NDNAD имеет федеративную архитектуру [Semikhodskii, A., 2007]: Северная Ирмандия и Шотмандия имеют собственные криминалистические базы ДНК, которые ежедневно экспортируют все новые данные в NDNAD, тогда как генетическая информация, полученная в Англии и Уэльсе, загружается туда напрямую (рис. 2). В Соединенных Штатах Америки существует подобная, причем многоуровневая, архитектура национальной криминалистической базы данных CODIS (рис. 3).

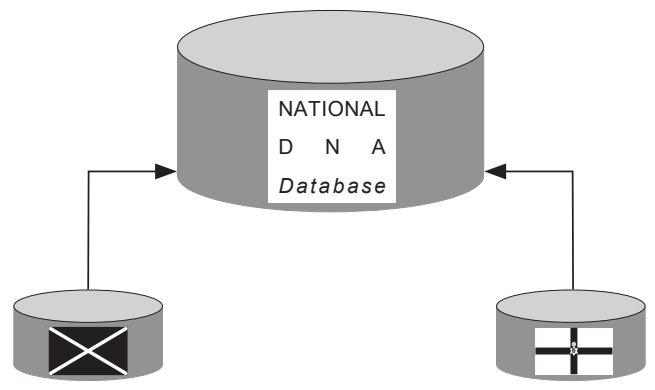

Puc. 2. Архитектура национальной криминалистической базы данных Соединенного Королевства NDNAD /

Pic. 2. Architecture of the National DNA Database of the United Kingdom NDNAD

Каждая из архитектур имеет свои преимущества и недостатки. При централизованной структуре один оператор занимается управлением базой данных, ее обслуживанием, контролирует качество входящих и хранящихся данных и несет ответственность за их безопасность. При федеративной архитектуре домжны быть созданы единая федеральная база и мокальные базы данных, число которых домжно быть определено ее правообладателем, назначены операторы для федеральной и каждой из региональных баз и внедрены единые стандарты контроля качества. $\Lambda$ кальные базы с опредеменной периодичностью домжны будут экспорти- 
ровать всю новую генетическую информацию, поставленную на криминалистический учет, в федеральную базу, которая будет интегрировать данные и выдавать результаты по запросам следствия. Учитывая географические факторы и наличие 85 субъектов Федерации, именно федеративная архитектура, по мнению автора, предпочтительна для Российской Федерации.

\section{CODIS}

Национальный уровень / National level

Уровень штата/

State level

Местный уровень /

Local level

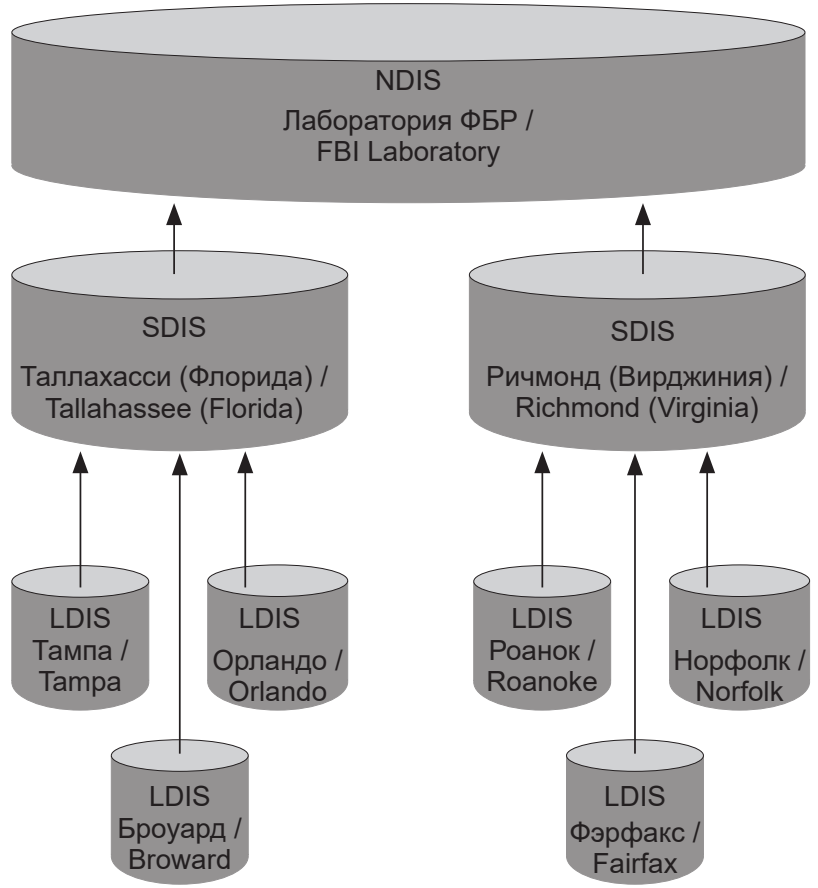

Puc. 3. Архитектура национальной криминалистической базы данных CШA CODIS /

Pic. 3. Architecture of the Combined DNA Index System (USA)

Национальная криминалистическая база данных CША CODIS имеет многоуровневую структуру. LDIS (local DNA index system) - местная база данных ДНK, SDIS

(state DNA index system) - база данных ДНК штата, NDIS (national DNA index system) - национальная база данных США. Каждая маборатория на местном уровне и на уровне штата поддерживает свою часть CODIS. Ааборатория ФБР поддерживает национальную базу целиком /

Combined DNA Index System of the USA (CODIS) has a multilevel structure: LDIS (Local DNA Index System), SDIS (State DNA Index System), NDIS (National DNA Index System). Each laboratory at the local and state level maintains its part of CODIS. The FBI laboratory maintains the whole national database. 


\section{Учетная запись в базе геномной информаиии - сведения,} характеризуюшие ДНК-профиль, и типы генетических данных Сведения, которые должны храниться в базе данных. Вопреки распространенному мнению, криминалистическая база геномной информации не является хранилищем истории преступной активности физического Аица, чьи данные в ней находятся. В ней хранятся только все необходимые параметры, позволяющие эффективно провести сравнение

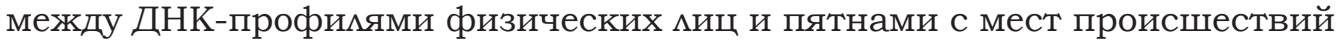
и ДНК-профилями, полученными следственным органами при расследовании новых преступлений.

Среди основных проблем баз данных ДНК - обеспечение конфиденциальности и безопасности хранимой генетической информации. Последствия утечки или неправильного обращения с этой информацией могут оказаться катастрофичными дия человека или его семьи. Решению этой проблемы служат регистрация и хранение только той информации, которая необходима дия осуществления целей базы данных, причем идентифицирующая информация о доноре образца отсутствует.

Taк, в американской CODIS хранится только четыре параметра: (1) идентификатор маборатории, загрузившей данные, (2) идентификатор образца, (3) ДНК-профиль и (4) идентификатор специалиста, ответственного за получение профиля [Butler, J. M., 2011]. B NDNAD кроме номера образца и самого ДНК-профиля заносят информацию об этническом (расовом) происхождении донора (семь различных этнических категорий), заявленный пол донора, его возраст и идентификатор маборатории, загрузившей данные ${ }^{17}$.

Идентификация Аичности субъекта не входит в функции базы данных. Обычно она проводится следственными органами на основе уже имеющейся у них предварительной информации и только в исключительных случаях - при помощи генетических методов. Основными функциями базы данных является сравнение ДНК-профиля субъекта (подозреваемого, свидетеля и т. д.) с ДНК-профилями биологических пятен с мест происшествия, которые в ней хранятся, а также сравнение ДНК-профиля биологического пятна, полученного в ходе расследования нового преступмения, с ДНК-профияем субъекта, уже стоящего в базе на учете. В США, Соединенном Королевстве и многих других странах цичная информация о субъекте, чей ДНК-профиль находится в базе данных генетической информации, хранится отдельно в специальной полицейской базе данных вместе с информацией о судимостях, адресах проживания и т. д. Там же хранится регистрационный номер профиля ДНК из генетической базы данных, по которому мичность субъекта может быть установцена.

17 National DNA Database Strategy Board Annual Report 2017/18 (2019). URL: https: / www.gov.uk/government/publications / national-dna-database-annualreport-2017-to-2018 (дата обращения: 30.06.2020). 
В британской NDNAD ДHK-профили идентифицируются исключительно по штрихкоду. Информация о том, какому физическому мицу принадмежит конкретный штрихкод, находится в Национальной полицейской базе (Police National Computer, PNC). При совпадении между генетическим профилем с места преступления и профилем, хранящимся в NDNAD, оператор генетической базы получает только номер совпадающего образца, который он передает следователю. Используя этот номер в качестве запроса в PNC, следователь получает полную информацию о доноре образца, включая настоящие и бывшие имена и фамилии, места проживания, все недавние и прошлые аресты, судимости и т. д. Такое разделение информации позволяет предотвратить коррупцию и змоупотребления, а также преднамеренную подмену генетической информации у конкретного мица.

Законодатель и правообладатель должны решить, будет $и$ генетическая информация в федеральной базе данных храниться в анонимизированной форме (в таком случае это должно быть нормативно закреплено), и определить параметры учетной записи, которые необходимы для осуществления ее целей. Так, учетная запись может содержать:

- штрихкод идентификатора образца;

- генетические данные;

- пол донора образца;

- дату рождения донора образца;

- этническое происхождение донора образца;

- экспертное подразделение, получившее генетические данные.

Генетическая информация, хранящаяся в базе данных, и биомогические образцы. Биологический образец, полученный от физического мица, содержит полную геномную информацию субъекта. В маборатории из образца выделяют суммарную ДНК, но анализируют в ней только небольшие участки генома, называемые "генетические маркеры", комбинация которых является индивидуализирующей для каждого чемовека.

Известно много разных типов ДНК-маркеров, но на сегодняшний день для целей идентификации человека используются только STR маркеры (от англ. Simple Tandem Repeats - простые тандемные повторы). Этот тип маркеров представцяет собой короткие последовательности ДНК, которые повторяются определенное количество раз. Полученный в результате анамиза генетический профимь (ДНК-профимь) представцяет собой буквенноцифровую таблицу, в которой по каждому проанализированному маркеру цифрами указываются присутствующие генетические варианты.

В настоящее время в мире нет единообразия в отношении количества используемых генетических маркеров для ДНК-идентификации, но в каждой юрисдикции для целей криминалистической базы геномных данных их количество и перечень строго регламентированы. Так, при создании британской NDNAD в 1994 г. использовалось 7 ДНК-маркеров. 
В 1999 году панель маркеров была расширена до 11, в середине 2014 г. до 17 маркеров. В США база CODIS с 1998 по 2016 г. содержала генетическую информацию по 13 маркерам, а начиная с 2017 г. число ДНКмаркеров было увеличено до 20.

В российской криминалистике такое единообразие отсутствует. Экспертные организации зачастую используют панели с разным количеством и перечнем маркеров даже дмя анализа образцов внутри одного уголовного дела, что не только затрудняет сравнение образцов, но и станет серьезной проблемой дмя федеральной базы генетической информации. Количество и перечень используемых ДНК-маркеров домжны быть установ ены правообладателем, и все экспертные подраздемения домжны их использовать дмя предоставмения генетической информации в базу данных.

Кроме этого, законодательно домжен быть урегулирован вопрос хранения биологических образцов и выделенной из них ДНК. Необходимость хранения образцов и выдеменной ДНК продиктована тем, что их наличие позволит при необходимости провести повторный анализ и предоставит возможность получать информацию по новым маркерным системам и с использованием новых технологий дмя уже находящихся в базе субъектов и профилей нераскрытых преступлений.

\section{Структура базы данных}

Несмотря на то что криминалистическая база данных ДНК является в первую очередь репозиторием генетической информации, полученной от

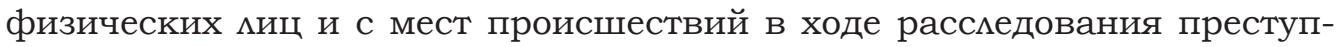
мений, дмя ее эффективного использования структура базы должна быть гораздо более обширна и вкцючать в себя информацию о мицах, не только не совершивших, но и не подозреваемых в совершении правонарушений. Из-за разного процессуального статуса $и ц$ чь ДиК-образцы помещены в базу данных, специфика запроса данных, критерии хранения информации и другие параметры будут размичны дмя каждой из категорий миц, поэтому целесообразно, чтобы база данных состояла из нескольких не связанных между собой реестров, содержащих информацию о конкретном типе субъектов. Подобная структура существует во многих странах с теми или иными модификациями.

В Соединенном Королевстве NDAND содержит несколько реестров, каждый из которых предназначен дмя хранения генетической информации опредеменной категории субъектов ими образцов:

1. Криминалистический реестр (содержит информацию, полученную с объектов, изъятых с мест происшествий в ходе следственных мероприятий);

2. Реестр подозреваемых и осужденных (содержит информацию об осужденных и других мицах, у которых согласно законодательству берутся образцы ДНК при расследовании правонарушений); 
3. Реестр лии исключения (содержит информацию о мицах, сдавших свою ДНК добровольно или из-за специфики своей работы/службы, для целей исключения их из числа подозреваемых, если только нет информации о противоположном). Такими реестрами явцяются:

i. Реестр добровольцев, сдавших образцы ДНК в ходе расследования правонарушения (например, при массовых сборах образцов для сужения круга подозреваемых);

ii. Реестр сотрудников экспертных подразделений, в которых получают генетическую информацию для базы данных;

iii. Реестр сотрудников полиции;

4. Реестр непознанных лии (содержит информацию о неопознанных трупах, жертвах природных и техногенных катастроф, жертвах военных конфмиктов);

5. Реестр уязвимъх лии (содержит информацию о социально слабозащищенных мицах, которые потенциально могут стать жертвами преступмений: например, несовершеннолетние с возможным риском сексуальной эксплуатации или торговли мюдьми, работники секс-индустрии, потенциальные жертвы домашнего насилия, мица, которые из-за возраста, инвамидности или психиатрического заболевания не могут позаботиться о себе или защитить себя, и т. д.). В данный реестр информация помещается исключительно на добровольной основе.

Дия каждого реестра должны быть разработаны критерии постановки на криминалистический учет, хранения и уничтожения генетической информации, а также критерии, по которым информация из одного реестра может быть перенесена в другой. Вопросы, связанные с реестром сотрудников правоохранительных служб и экспертных организаций, могут быть регламентированы правообладателем базы, однако вопросы, прямо затрагивающие права и свободы человека, нуждаются в законодательном решении.

\section{Критерии для постановки на криминалистический учет и сроки хранения информачии}

Критерии постановки на учет и удаления генетической информации из базы данных, а также срок ее хранения - основные параметры, требующие правового регулирования. Здесь законодателю необходимо соблюсти разумный баланс между защитой основных прав человека, эффективностью борьбы с правонарушениями и обеспечением общественной безопасности в цемом.

Преступмения, подмежащие генетической регистрации. Считается, что основные критерии правонарушений, за совершение которых генетическая информация должна ставиться на учет, - это их характер и тяжесть. Убийства, терроризм и преступления против Аичности, в том числе против половой неприкосновенности и половой свободы, очевидно должны вкАючаться в список преступлений, подлежащих генетической регистрации. Однако мировой опыт показывает, что, если база будет со- 
держать информацию, взятую при расследовании только этих преступмений, ее эффективность будет заведомо низкой ${ }^{18}$. Разумеется, данные преступления должны регистрироваться, как минимум, исходя из тяжести их последствий, но с точки зрения раскрытия дмя многих преступлений из этого списка ДНК-экспертиза не явцяется наиболее эффективным методом идентификации преступника. При расследовании преступлений против половой неприкосновенности и убийств в большинстве случаев мичность подозреваемого не вызывает сомнений: дмя ее установления наиболее эффективны прямые доказательства - показания жертвы, свидетелей, записи с камер наблюдения. Только в небольшом проценте пре-

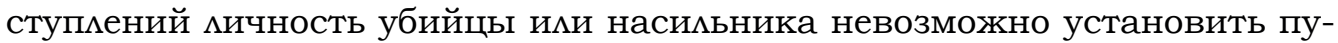
тем стандартных следственно-розыскных мероприятий.

Это подтверждается статистикой раскрываемости таких категорий преступлений за 2019 г., опубликованной МВД России ${ }^{19}$. Даже при текушем состоянии ФБДГИ раскрываемость убийства или покушения на убийство, умышленное причинение тяжкого вреда здоровъю и изнасилование или покушения на изнасилование составляет соответственно 91,9\%, 94,9\% и 98,4\%.

Статистика использования национальной базы данных ДНК Соединенного Королевства также подтверждает ее малую эффективность дмя раскрытия убийств, причинения тяжкого вреда здоровью и изнасилований ${ }^{20}$.

Не только удельная доля ДНК-профилей с биологических пятен, изъятьх при расследовании всех видов убийств, изнасилований и других преступлений на половой почве, загруженных в NDNAD, составляет соответственно $2 \%, 2 \%$ и 1\% от обиего количества генетических профилей по всем преступлениям, но и по этим же преступлениям удельная доля совпадений между загруженными профилями физических лии и профилями биологических пятен еше не раскрытых преступлений (около 645 тыс. ДНК-профрилей), храняиилися в базе, составляет соответственно 2,3\%, 2,3\% и 0,6\% ${ }^{21}$.

Необходимо также учитывать то, что в Российской Федерации удемьный вес тяжких и особо тяжких преступлений из общего числа зареги-

18 National DNA Database Strategy Board Annual Report 2017/18 (2019). URL: https: / /www.gov.uk/government/publications / national-dna-database-annualreport-2017-to-2018 (дата обращения: 30.06.2020).

19 МВД России. Состояние преступности в России за январь - декабрь 2019 г. М., 2020. URL: https://media.mvd.ru/files/application/1748898 (дата обращения: 29.06.2020).

20 National DNA Database Strategy Board Annual Report 2017/18 (2019). URL: https: / / www.gov.uk/government/ publications / national-dna-database-annualreport-2017-to-2018 (дата обращения: 30.06.2020).

21 National DNA Database Strategy Board Annual Report 2017/18 (2019). URL: https://www.gov.uk/government/publications/national-dna-database-annualreport-2017-to-2018 (дата обращения: 30.06.2020). 
стрированных преступлений за 2019 г. составляет 24,4\% ${ }^{22}$, т. е. согласно Закону "О государственной геномной регистрации" на сегодняшний день три четверти преступлений, совершенных в Российской Федерации, не подпадают под геномную регистрацию (ст. 7).

Вопрос о категории преступлений, при расследовании которых домжны изыматься биологические образцы дия генетической регистрации, явмяется предметом дискуссий с участием адвокатского корпуса и право-

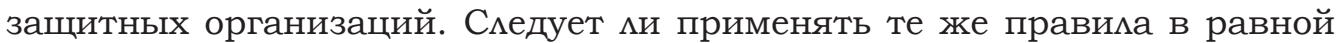
степени к подозреваемому в изнасицовании и к подозреваемому в краже продуктов из супермаркета? С криминологической точки зрения основная причина, по которой отбираются образцы дмя ДНК-анализа, вполне

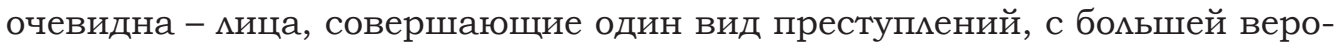
ятностью совершают и другие виды преступлений [Gottfredson, M. R. and Hirschi, T., 1990]. Начиная с мелких противоправных деяний правонарушители впоследствии часто "прогрессируют" в сторону совершения более серьезных, насицьственных преступцений.

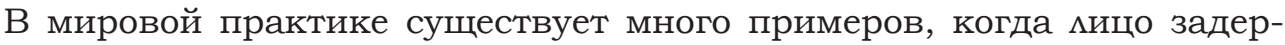
живалось за совершение малозначительного преступления, а его профиль ДНК совпадал с профилем ДНК подозреваемого в убийстве ими изнасимовании, совершенном некоторое время назад, уже находящемся в криминалистической базе генетической информации.

Согласно данным правоохранительных органов США ДНК-профили 82\% преступников, проходяиих по делам, связанньм с такими преступлениями, как убийства и изнасилования, ранее уже были поставлены на учет в базе данных ДНК в результате предварительного осуждения за совершение менее серьезного преступления, такого как кража со взломом или продажа наркотиков. В исследовании, проведенном в итате Флорида (США), в 52\% случаев обрашений к базе данных по делам об убийствах и сексуальных посягательствах были выявлены совпадения с лииами, которые ранее были осуждены за кражу со взломом [Zedlewski, E. and Murphy, M. B., 2006]. Результаты использования базы данных ДНК штата Нью-Йорк (США) показали, ито обвиняемые в совершении насильственных преступлений почти всегда имели судимость за совершение ненасильственных преступлений в прошлом. ДНК-профили в базе данных осужденных за совершение преступлений небольшой тяжести (таких, как кража) совпадали с ДНК-профилями биологических пятен, изъятых при расследовании 685 преступлений, включая 175 сексуальных посягательств, 82 грабежа и 36 убийсmв ${ }^{23}$.

22 МВД России. Состояние преступности в России за январь - декабрь 2019 г. М., 2020. URL: https://media.mvd.ru/files/application/1748898 (дата обращения: 29.06.2020).

23 Управление уголовного правосудия штата Нью-Йорк. Пресс-релиз от 19 августа 2010 г. URL: https://www.criminaljustice.ny.gov/pio/press_releases/2010-8-19_ pressrelease.html (дата обращения: 11.11.2020). 
С точки зрения обеспечения правопорядка взятие образцов ДНК при расследовании краж, других преступлений против собственности и остальных нетяжких преступлений обосновывается тем, что такие правонарушения приводят к экономическим потерям и психологическим травмам у миц, против чьего имущества они были совершены, а их большое количество создает серьезные проблемы в обществе и вызывает недоверие к системе охраны правопорядка. На раскрытие таких преступлений тратится значительное количество усилий, они имеют один из самых низких уровней раскрываемости, а их регистрация в базе данных ДНК значительно увеличит раскрываемость таких преступлений.

Правозащитные организации считают такую позицию спорной, ссылаясь на большое число тех, кто после малозначительного впоследствии не совершал другого противоправного деяния, а большое количество осужденных за совершение убийства или изнасилования никогда раньше не подозревамись в совершении уголовно наказуемых правонарушений. Пытаясь как-то сбалансировать эти две точки зрения, в ряде юрисдикций используют вид и минимальный срок предусмотренного за совершение преступления наказания в качестве основного критерия для включения ДНК-профиля в базу генетических данных [Schneider, P. M. and Martin, P. D., 2001].

Опыт стран, в которых созданы национальные криминалистические базы данных ДНК, показывает размичия между используемыми критериями регистрации генетической информации.

Так, в Соединенном Королевстве образиы для базы данных ДНК берутся за все регистрируемые преступления ${ }^{24}$; в Австрии - за преступления против жизни и здоровья, изнасилование, кражу и грабеж, связанные с наркотическими веществами, шантаж и ряд других; в Швеции - за преступления, предусматриваюшие как минимум два года тюремного заключения; в Дании - за преступления, предусматривающие как минимум полтора года тюремного заключения; в Германии - за преступления, предусматриваюшие как минимум один год тюремного заключения [Schneider, P. M. and Martin, P. D., 2001].

Еще одним важным критерием выбора может выступать эффективность расследования размичных типов правонарушений при помощи генетической экспертизы. Анализ результативности британской NDNAD для раскрытия разных типов преступлений показывает, что база данных

24 Согласно текущему законодательству (The National Police Records (Recordable Offences) Regulations 2000. URL: https: / / www.legislation.gov.uk/uksi/2000/1139/ made (дата обращения: 15.11.2020) регистрируемыми преступлениями (Recordable offence) явцяются цюбые правонарушения, по которым полиция должна вести учет вынесенных судом приговоров и правонарушителей в Национальной полицейской базе данных (Police National Computer). Kaк правило, это преступцения, за которые предусмотрено тюремное заключение, но они также вкАючает в себя категории преступлений, не предусматривающие мишение свободы (например, попрошайничество). 
ДНК наиболее эффективна при расследовании тех преступлений, когда на момент получения правоохранительным органом информации о преступлении мицо, его совершившее, неочевидно ${ }^{25}$.

Так, согласно данным британской NDNAD на неочевидные преступления приходится более половины ежегодно загружаемых ДНК-профилей, полученных из биологических пятен с мест преступлений, и в более чем 60\% случаев наблюдается совпадение с ДНК-профилем физического лииа, уже хранящиися там ${ }^{26}$.

Таким образом, при выборе типов преступлений, при совершении которых генетическая информация должна заноситься в базу данных ДНК, законодателю необходимо учитывать не только тип и тяжесть преступления, но и криминологические аспекты преступного поведения и относительное количество тех правонарушений, при которых будут изыматься биологические образцы, от числа всех зарегистрированных правонарушений. Следует также учитывать то, что эффективность базы данных при раскрытии преступлений наиболее высока, когда остальные средства идентификации мибо не могут быть использованы, мибо их доказательная сила в суде ниже, чем ДНК-доказательства.

У какой процессуапьной категории миц берутся образцы дНК. Во время расследования преступления образцы для ДНК-профилирования могут быть изъяты как с места происшествия, так и у физических $и и ц-$ жертв преступления, Аиц, подозреваемых в их совершении, добровольцев, чья генетическая информация необходима для целей исключения. Дия эффективного использования следственные органы должны иметь возможность проверки подозреваемого с целью установцения того, мог $\Lambda$ он быть донором ДНК в биологическом пятне с места происшествия. Полученные результаты генетической экспертизы позволят исключить конкретного подозреваемого из числа подозреваемых, или же, наоборот, совпадение его ДНК-профиля с профимем пятна с места происшествия может стать основанием для предъявмения обвинения в совершении расследуемого преступцения.

В странах, где уже созданы криминалистические базы, нет единообразия по поводу того, у каких категорий миц берутся образцы ДНК.

Так, в США и большинстве стран Европейского союза образиы ДНК берутся у подозреваемых и осужденных за квалифииируемые преступления, тогда как в Германии образиы ДНК берутся только у лии, которым вынесено офиииальное обвинение в совершении преступления, в Португалии только у осужденных [Machado, H. and Granja, R., 2020], а в Соединенном

25 National DNA Database Strategy Board Annual Report 2017/18 (2019). URL: https://www.gov.uk/government/publications/national-dna-database-annualreport-2017-to-2018 (дата обращения: 30.06.2020).

26 Ibid. 
Королевстве - у всех задержанных по подозрению в совершении "регистрируемого" преступления [Semikhodskii, A., 2007].

С точки зрения эффективности расследования преступлений могично брать образцы ДНК у всех миц, которые, по мнению следствия, могут быть причастны к их совершению, - подозреваемых и обвиняемых, а также у свидетелей с целью искмючения. Законодатель должен предусмотреть дия

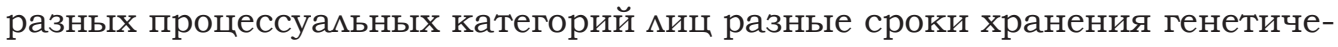
ской информации мибо, в определенных случаях, возможность отказа от сдачи образцов без последующих санкций.

Сроки хранения ннформацин. Эффективный режим хранения генетической информации домжен соответствовать законодательству о правах человека, не нарушать гражданские свободы мюдей, особенно право на неприкосновенность частной жизни. Хранение генетической информации осужденных как минимум в течение всего периода их жизни может быть оправданно с точки зрения общественной безопасности, но дия миц, против которых не было выдвинуто обвинение или которые не были признаны судом виновными, сроки домжны строго регламентироваться законодатемьно.

Ярким примером надмежащего регулирования этих вопросов явцяется Соединенное Коромевство, где только после 15 мет судебных разбирательств внутри страны и решения Европейского Суда по правам человека $^{27}$ были законодательно ${ }^{28}$ установцены правила касательно срока хра-

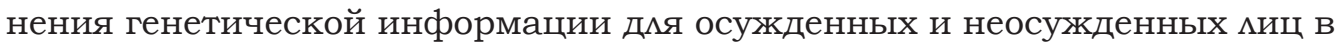
британской NDNAD (табл. 1).

В тех случаях, когда ДНК-профиль законодательно не может больше храниться, перед удалением разрешается его использование дмя проведения одного пробного поиска в NDNAD. Если поиск не дал результатов, то профимь изымается из базы данных, однако в случае обнаружения совпадения он будет продомжать храниться на время расследования, а по результатам расследования его статус опредемяется согласно правилам удерживания (например, если расследование привело к осуждению за тяжкое преступление, то профимь будет храниться бессрочно). Такие пра-

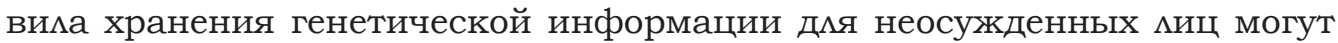

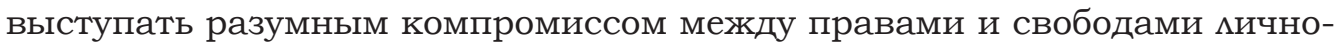

27 Постановление Европейского Суда по правам человека по делу «S and Marper v The United Kingdom" [2008]. URL: http:/ /www.bailii.org/eu/cases/ECHR/2008/1581. html (дата обращения: 11.11.2020). Это решение, согласно которому хранение генетической информации и образцов ДНК мица, не осужденного за совершение уголовно наказуемого преступления, противоречит ст. 8 и 14 Конвенции о защите прав и основных свобод человека, следует учитывать и при разработке соответствующего законодательства в Российской Федерации.

28 Protection of Freedoms Act 2012. URL: https://www.legislation.gov.uk/ ukpga/2012/9/pdfs/ukpga_20120009_en.pdf (дата обращения: 21.10.2020). 
сти и правом общества находиться в безопасности. Российскому законодателю необходимо будет разработать аналогичные положения о сроках хранения информации о мицах, процессуальные действия в отношении которых не достигли суда или которые были оправданы судом, принимая во внимание не только пожелания органов защиты правопорядка, но и мнение правозащитных организаций. Опыт Соединенного Королевства в этой области может быть поцезным дмя выработки соответствующих правиц и норм.

таблииа 1 / Table 1

\section{Сроки хранения генетической информации в Национамьной криминахистической базе данных дНК Соединенного Королевства (NDNAD) / Genetic information retention period at the National DNA Database of the UK (NDNAD)}

\begin{tabular}{|c|c|c|}
\hline \multicolumn{2}{|c|}{ Категория / Category } & $\begin{array}{l}\text { Срок хранения генетической информации / } \\
\text { Genetic information retention period }\end{array}$ \\
\hline \multicolumn{3}{|c|}{ Осужденные / Covicted individuals } \\
\hline $\begin{array}{l}\text { Лица старше } \\
18 \text { лет }^{1} / \\
\text { Over } 18 \text { persons }\end{array}$ & $\begin{array}{l}\text { Все «регистрируемые»² пре- } \\
\text { ступления / All "registered" } \\
\text { offences }^{2}\end{array}$ & Бессрочно / Indefinitely \\
\hline \multirow{2}{*}{$\begin{array}{l}\text { Лица, не до- } \\
\text { стигшие } 18 \text { лет / } \\
\text { Under } 18 \text { persons }\end{array}$} & $\begin{array}{l}\text { Тяжкие преступления / } \\
\text { Qualifying offences }\end{array}$ & Бессрочно / Indefinitely \\
\hline & $\begin{array}{l}\text { Мелкие преступления / Minor } \\
\text { offences }\end{array}$ & $\begin{array}{l}\text { Первая судимость: } 5 \text { лет плюс срок заключения. } \\
\text { Вторая судимость или предыдущее тюремное } \\
\text { заключение на срок более } 5 \text { лет: бессрочно / } \\
\text { First conviction: } 5 \text { years plus length of sentence. } \\
\text { Second conviction or previous convictions longer } \\
\text { than } 5 \text { years: Indefinitely }\end{array}$ \\
\hline \multicolumn{3}{|c|}{ Не осужденные / Non-convicts } \\
\hline \multicolumn{2}{|c|}{ Мелкие преступления / Minor offences } & $\begin{array}{l}\text { Удаляются после завершения следствия и/или } \\
\text { судебного разбирательства / Removed after the } \\
\text { conclusion of investigation or any proceedings }\end{array}$ \\
\hline \multicolumn{2}{|c|}{$\begin{array}{l}\text { Предъявлено обвинение в совершении тяжкого } \\
\text { преступления / Charged with a qualifying offences }\end{array}$} & $\begin{array}{l}3 \text { года (может быть продлено на } 2 \text { года по реше- } \\
\text { нию суда) / } 3 \text { years (may be extended for } 2 \text { years } \\
\text { by a court order) }\end{array}$ \\
\hline \multicolumn{2}{|c|}{$\begin{array}{l}\text { Aрестован за тяжкое преступление / Arrested for } \\
\text { a qualifying offences }\end{array}$} & $\begin{array}{l}3 \text { года с разрешения Комиссара по удержанию и } \\
\text { использованию биометрического материала (мо- } \\
\text { жет быть продлено на } 2 \text { года по решению суда) / } \\
3 \text { years if granted by the Biometrics Commissioner } \\
\text { (may be extended for } 2 \text { years by a court order) }\end{array}$ \\
\hline \multicolumn{2}{|c|}{$\begin{array}{l}\text { Оштрафован за публичные беспорядки / Issued } \\
\text { with a Penalty Notice for Disorder }\end{array}$} & 2 года / 2 years \\
\hline
\end{tabular}

${ }^{1}$ Срок уголовной ответственности в Соединенном Королевстве наступает в возрасте 10 мет / The age of criminal responsibility in the United Kingdom is 10 years old. 
2 Согласно английскому законодательству все уголовно наказуемые преступления подраздемяются на регистрируемые (registered offences), тяжкие (qualifying offences) и мелкие (minor offences). Регистрируемое преступление - это мюбое преступцение,

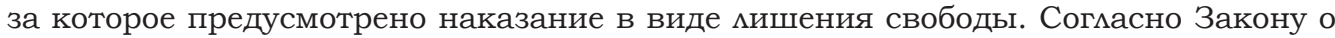
полиции и уголовных доказатецьствах 1984 г. ${ }^{29}$ тяжкое преступление - это преступмение против половой неприкосновенности мичности, убийство, терроризм, грабеж, кража; мелкие преступления - это регистрируемые, но не тяжкие преступления / Under English law, all punishable offences are divided into registered offences, qualifying offences, and minor offences. A registered offences is any offence punishable by imprisonment. According to the Police and Criminal Evidence Act $1984^{29}$ a qualifying offences is an offences such as murder, manslaughter, rape, wounding, grievous bodily harm, assault occasioning actual bodily harm, robbery and burglary; also included are numerous sex, indecency and firearms offences; minor offences are registered but not qualifying offences.

Федеральным законом "О государственной геномной регистрации в Российской Федерации" дмя миц, осужденных и отбывающих наказание в виде $\Lambda$ шения свободы за совершение тяжких ими особо тяжких преступмений, а также всех категорий преступлений против половой неприкосно-

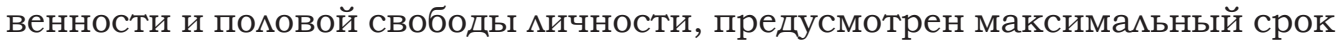
хранения геномной информации - до установмения факта смерти субъекта, а при отсутствии сведений о его смерти - до даты, когда ему испо нилось бы 100 мет ${ }^{30}$. Дия неустановленных $и$ б, биологический материал которых изъят в ходе производства следственных действий, установцен срок хранения 70 мет с момента его получения ${ }^{31}$. Геномная информация, полученная при проведении государственной геномной регистрации не-

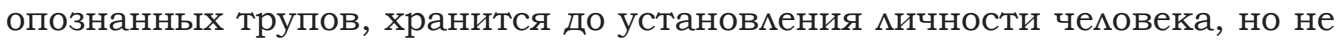
более 70 мет ${ }^{32}$. Этим Законом сроки хранения генетической информации миц, проходивших по дему, но против которых обвинение так и не было

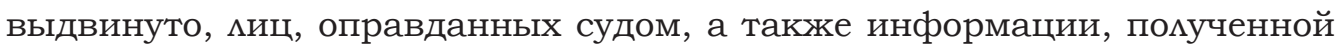
из биологических пятен с мест происшествий, не установцены.

Современные достижения в области математических методов анализа генетических данных и генетической генеалогии позволяют идентифицировать преступника по генетической информации его давно умершего родственника, если она имеется в базе данных. Поэтому, с точки зрения автора, верхний мимит срока хранения информации должен быть отменен и информация должна храниться бессрочно, даже после смерти субъекта.

29 S. 65A Police and Criminal Evidence Act 1984. URL: https://www.legislation.gov. uk/ukpga/1984/60/pdfs/ukpga_19840060_en.pdf (дата обращения: 22.10.2020).

30 Пункт 1 ст. 12 Закона № 242-ФЗ.

31 Пункт 2 ст. 12 Закона № 242-Ф3.

32 Пункт 3 ст. 12 Закона № 242-ФЗ.

Правосудие/Justice. Т. 3, № 1. 2021. Оригинальные статьи 
Отдемьно стоит рассмотреть вопрос хранения генетической информации биологических пятен с мест преступлений, по которым уже вынесен обвинительный приговор. Здесь также примечателен британский опыт.

До 2006 года в Соединенном Королевстве было невозможно сравнивать новые профили субъектов, заносяшиеся в базу данных, с профилями пятен с мест происшествия по преступлениям, по которым уже был вынесен обвинительный приговор. После вынесения обвинительного приговора генетическая информаиия пятна с места преступления удалялась: считалось, ито ДНКпрофиля осужденного будет достаточно в качестве прокси ДНК-профиля пятна для последуюших сравнений. Однако многие ДНК-профили образиов с места преступления являются неполными или смешанными. Замена неполного и/ или смешанного профиля полным профилем одного человека делает практически невозможной идентификаиию альтернативных и дополнительных подозреваемых при пересмотре дела в будушем. Новый загруженный ДНК-профиль субъекта может совпасть с частичным или смешанньм профилем образиа с места совершения преступления, но вероятность его совпадения с полньм профилем осужденного человека крайне низкая. Отсутствие в базе данных генетической информаиии образиов с места преступления для таких преступлений делало невозможными генетический анализ при апелляиии и пересмотре дела по вновь открывиимся обстоятельствам, а также проверку других субъектов, которые сознались в совериении преступления, за которое уже вынесен обвинительный приговор другому человеку. В результате меры по удалению генетических профилей образиов с места преступления после вынесения обвинительного заключения были отменены.

Российскому законодателю при разработке норм и правиц относительно сроков хранения генетической информации в базе данных предстоит решить, домжна $и$ генетическая информация, полученная от совершен-

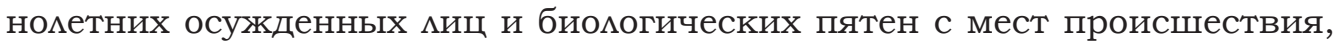
храниться бессрочно, или срок хранения должен быть ограничен. Необходимо будет опредемить сроки хранения информации дмя других кате-

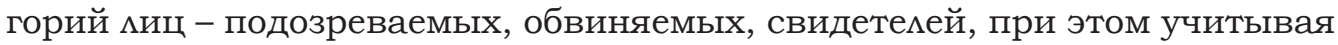
возраст субъекта и тяжесть правонарушения. Также необходимо будет разработать специальные правила, регламентирующие хранение генетический информации миц, у которых обвинитемьный приговор бым отменен судом вышестоящей инстанции или судимость снята.

\section{Процедуры получения биологических образиов}

При расследовании преступлений образцы у субъекта берутся в двух случаях: в целях установ ения, мог $и$ субъект оставить свой генетический материал на месте происшествия, и с целью обнаружения на теле субъекта биологических следов, связывающих его с местом преступления.

Источник и процедура получения биологического образца от субъекта дмя генетической экспертизы домжны быть законодатемьно регламентированы, поскольку они прямо связаны с защитой основных прав человека на 
мичную неприкосновенность: недопустимы действия и обращение, унижающие честь и человеческое достоинство субъекта, оскорбляющие его религиозные убеждения, создающие опасность дмя его жизни и здоровья. Это ставит вопросы о праве на отказ от сдачи образца или какого-то конкретно типа образца, возможности применения симового принуждения, его степени и случаях, в которых оно может быть применено.

Учитывая множество процедурных тонкостей и этических особенностей взятия биологического материала, во многих странах законодательно подразделяют образцы в зависимости от того, можно $и$ субъекту отказаться от их сдачи, а в случае отказа - возможно $и$ принуждение с применением симы.

Так, в Соединенном Королевстве выделят два типа биологических образиов, которые могут быть взяты у субъекта для проведения криминалистической генетической экспертизы: интимные и неинтимные [Semikhodskii, A., 2007]. Интимными образиами являются образиы крови, спермы или любой другой тканевой жидкости, мочи или лобковых волос, а также мазок, взятый из любого отверстия в теле человека, кроме ротового отверстия. Неинтимные образиы - это образеи волос (кроме лобковых), образеи, взятый с поверхности ногтя или из-под ногтя, мазок, взятый из любой части тела человека, а также ротового отверстия (но не из любого другого отверстия тела). Для взятия интимных образиов согласие субъекта обязательно. Если лиио не дает согласия, образеи не может быть взят принудительно. Субъект должен дать согласие на взятие и неинтимного образиа, но в некоторых случаях образиы могут быть взяты и без его согласия, причем закон разрешает в случае необходимости применение "разумной силь". Неинтимнье образиы могут быть взяты без согласия субъекта, если:

а) лиио содержится под стражей в полииии в связи с его арестом за регистрируемое правонарушение или содержится под стражей полииией на основании разрешения суда и

б) у него в ходе расследования преступления не было взято образиа неинтимного характера того же типа и/ или из той же части тела или образеи, взятый до того, оказался недостаточным для проведения экспертизы.

Кроме этого, вне зависимости от того, находится ли человек под стражей в полииии или нет, неинтимный образеи может быть взят без соответствуюшего согласия, если этому человеку было предъявлено обвинение в совершении "регистрируемого" преступления или если ему было сообшено, ито о нем будет заявлено как о человеке, совершившем "регистрируемое" преступление, или он был признан судом виновным в совершении "регистрируемого" преступления ${ }^{33}$.

Наиболее распространенным видом неинтимного образца, который берется в Вемикобритании у субъекта дия проведения ДНК-идентификации,

33 S. 63 Police and Criminal Evidence Act 1984. URL: https://www.legislation.gov.uk/ ukpga/1984/60/pdfs/ukpga_19840060_en.pdf (дата обращения: 22.10.2020). 
является ротовой мазок. Подавляющее большинство генетической информации в NDNAD получено именно из данного типа образца.

Хотя ДНК-анализ используется российскими правоохранительными службами уже более 30 мет, в Российской Федерации, в отличие от законодательства многих стран, отсутствует нормативно-правовое регулирование типов образцов, которые следствие может взять у субъекта для

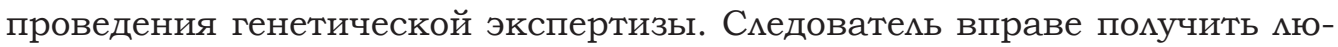
бые образцы для сравнительного исследования у подозреваемого, обвиняемого, свидетеля, потерпевшего, а также у иных физических миц и представителей юридических миц в случаях, когда возникла необходимость проверить, ими $\Lambda$ оставлены следы в определенном месте или на вещественных доказательствах ${ }^{34}$.

Наиболее распространенным типом биологического образца для генетической идентификации в Российской Федерации является кровь. Взятие крови - это медицинская процедура, для которой требуются специально подготовценный медицинский персонал, мицензированное помещение и медицинское оборудование. Процедура взятия крови болезненна, при ее проведении существуют ятрогенные риски, такие как инфекционное заражение или возникновение кровотечений (особенно у мюдей с нарушениями свертываемости крови). Для некоторых категорий миц взятие крови может быть затруднено или же неприемлемо по религиозным причинам. В этой связи целесообразно законодательно закрепить возможность взятия альтернативного типа образца, такого как ротовой мазок. У субъекта, вне зависимости от его процессуального статуса, всегда будет выбор, какой тип образца сдавать дия проведения генетической экспертизы, а у следствия всегда будет альтернатива, какой образец брать у субъекта для идентификации в случае его отказа от сдачи образца крови.

В российском законодательстве не решены вопросы о согласии субъекта на сдачу образца дмя проведения генетической экспертизы и применении силы для физического принуждения в случае его несогласия. Текущее законодательство не предусматривает отказ субъекта от сдачи образца, а использование физического принуждения при отсутствии согласия субъекта на взятие образца не регулируется, только упоминается, что при проведении процедуры получения образцов недопустимо применение методов, опасных для жизни и здоровья человека или унижающих его честь и достоинство ${ }^{35}$.

С точки зрения презумпции невиновности изъятие образцов дмя ДНКанализа у миц, которые не осуждены за совершение конкретного преступ-

34 Статья 202 Уголовно-процессуального кодекса Российской Федерации (с изм. на 27.10.2020). URL: http://docs.cntd.ru/document/901802257/ (дата обращения: 11.11.2020).

35 Статья 9 Уголовно-процессуального кодекса Российской Федерации (с изм. на 27.10.2020). URL: http://docs.cntd.ru/document/901802257/ (дата обращения: 11.11.2020). 
мения и которым не было предъявцено обвинение в его совершении, может рассматриваться как предоставление доказательств их невиновности. Сдача образцов домжна быть их свободой выбора, и принуждение

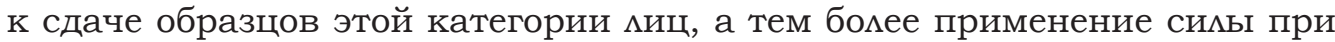
взятии образцов, какой бы она ни была, может рассматриваться как прямое нарушение конституционных прав чемовека. Это серьезный мотив дия того, чтобы данная процессуальная категория имела выбор, предоставцять $\Lambda$ образцы дия проведения экспертизы или отказаться от этой процедуры.

Доказательная ценность генетической информации является одной

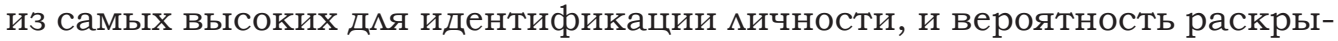
тия преступления зачастую напрямую зависит от наличия образца фигуранта у органов следствия. Статья 22 Конституции Российской Феде-

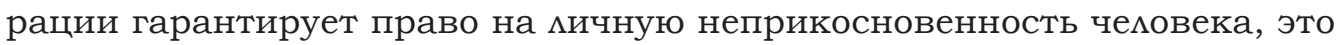
касается и наличия согмасия на взятие у него биологического образца. Ущемление данных конституционных прав у категории мюдей, которые обвиняются в совершении расследуемого преступления ими же признаны судом виновными в его совершении, может быть оправдано необходимостью поддержания общественной безопасности, но ущемление этих прав у мюдей, которые не явцяются обвиняемыми или осужденными, вызывает много споров. В такой ситуации подход законодатемей Соединенного Королевства и ряда других стран, установивших разделение биологических образцов человека на типы, запрет на взятие одного типа у опредеменной категории субъектов без получения согласия и, наоборот, возможность получения другого типа образцов без предварительного согласия, выглядит рациональным компромиссом. Такого рода опыт может быть испоцьзован в России при разработке соответствующих норм и правиц.

\section{Управление контролем качества данных}

Качество базы геномной информации прямо зависит от качества содержащихся в ней генетических данных. Некачественные генетические данные не только дорого обойдутся государству, но будут вииять на увемичение сроков раскрытия преступлений и даже могут стать причиной судебных ошибок. Поэтому качество генетических данных домжно контролироваться на протяжении всего жизненного цикла, начиная от их регистрации и до удаления из базы в случаях, предусмотренных законодательством.

В схему управцения контролем качества генетической базы данных домжны входить контроць за процессом постановки на учет и удаления генетической информации, поддержание целостности хранящихся данных, регулирование доступа к базе, внедрение стандартных операционных процедур и системы менеджмента качества (ISO сертификации). Одновременно домжна быть создана эффективная система компьютерной 
безопасности. Немаловажными будут сертификация и мицензирование экспертных подраздемений - поставщиков генетической информации правообладателем базы данных, вне зависимости от наличия у них ISO

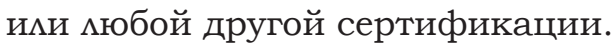

Оставцяя систему организации компьютерной безопасности, внутреннюю стандартизацию и ISO сертификацию базы и экспертных подраздемений за рамками данного обзора, рассмотрим два основных параметра качества, требующих нормативного регулирования:

1) количество и перечень ДНК-маркеров, по которой проводится генетическая идентификация;

2) минимальное количество генетических маркеров ДНК-профиля субъекта и ДНК-профиля биологического пятна с места происшествия, позволяющее постановку профиля на криминалистический учет в базу данных.

Такие требования разработаны руководством большинства крупнейших мировых криминалистических баз данных. Так, ФБР США (правообладатель национальной криминалистической базы CODIS) предъявляет следующие требования дмя поступающей в базу данных информации:

1) данные ДНК домжны быть помучены в соответствии со Стандартами обеспечения качества, которые установценные приказом директора ФБР;

2) данные ДНК домжны быть получены мабораторией, аккредитованной утвержденным агентством аккредитации;

3) данные ДНК домжны быть получены мабораторией, которая каждые два года проходит внешний аудит, чтобы продемонстрировать соответствие Стандартам обеспечения качества, установиенным приказом директора ФБР;

4) данные ДНК домжны быть одним из определенных федеральным законодательством понятий, таких как осужденный, арестованный, задержанный, эксперт-криминалист, неопознанные человеческие останки и т. д.;

5) данные ДНК домжны соответствовать минимальным требованиям CODIS дмя категории образца;

6) данные домжны быть получены с использованием одобренных наборов реактивов;

7) участвующие маборатории домжны строго соблюдать процедуры удаления генетической информации в соответствии с федеральным законом $^{36}$.

Чтобы учесть новый профимь в базе данных, он должен содержать генетическую информацию по установленному минимуму ДНК-маркеров. Это демается дия того, чтобы избежать накопления низкоинформативных генетических данных, которые будут увеличивать количество случайных

36 FBI DNA Data Requirements. URL: https://www.fbi.gov/services/laboratory/ biometric-analysis/codis/codis-and-ndis-fact-sheet\#PCR-STR\%20Kits (дата обращения: 01.11.2020). 
совпадений, затрудняя работу следствия, и могут стать причиной судебной ошибки. Для NDNAD такими условиями являются:

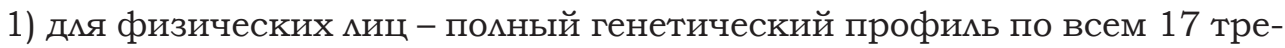
буемым генетическим маркерам;

2) дмя биологических пятен с мест происшествия - полная генетическая информация как минимум по четырем маркерам (8 амлемей) и маркеру пома ${ }^{37}$.

Если ДНК-профиць пятна с места преступления не соответствует предъявляемым требованиям, его нельзя поместить в базу данных, но можно использовать дия проведения запроса ${ }^{38}$.

CODIS предъявляет похожие требования к загружаемым данным:

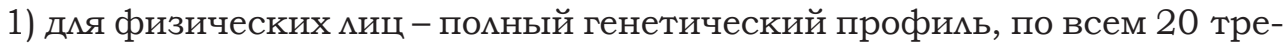
буемым генетическим маркерам;

2) дмя родственников миц, пропавших без вести, - полный генетический профиль по всем требуемым генетическим маркерам и маркер пола;

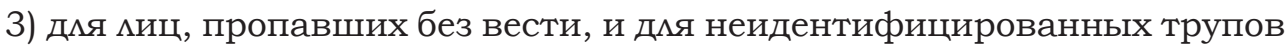
домжно осуществляться генотипирование по всем 20 требуемым генетическим маркерам;

4) дия биологических пятен с мест происшествия - минимум информации по 8 маркерам в сочетании с вероятностью случайного совпадения менее чем один на десять мимиионов ${ }^{39}$.

На сегодняшний день в российской криминалистике отсутствует единый стандарт в отношении используемого количества и перечня STR маркеров дмя генотипирования. Исходя из этого домжны быть разработаны нормативные документы, которые унифицируют количество и перечень генетических маркеров, информация по которым будет помещаться в базу данных, установят стандарты контроля качества к загружаемым генетическим данным, закрепят требования к методологии анализа и $\mathrm{k}$ экспертным подраздемениям, которые занимаются судебно-генетической экспертизой в ходе расследования преступцений.

\section{Использование генетической информации и криминалистических баз данных днк: вопросы этики}

Этические вопросы, которые возникают в связи с созданием и использованием генетической базы в криминалистических целях, можно свести к

37 National DNA Database Strategy Board Annual Report 2017/18 (2019). URL: https:/ / www.gov.uk/government/ publications / national-dna-database-annualreport-2017-to-2018 (дата обращения: 30.06.2020).

38 Ibid.

39 FBI DNA Data Requirements. URL: https://www.fbi.gov/services/laboratory/ biometric-analysis/codis/codis-and-ndis-fact-sheet\#PCR-STR\%20Kits (дата обращения: 01.11.2020). 
трем основным группам: 1) вопросы, связанные со взятием и хранением образцов ДНК и полученной из них информации; 2) вопросы, связанные с использованием полученной в результате такого анализа генетической информации; 3) вопросы, связанные с доступом к хранящейся информации.

Как уже упоминалось выше, генетические данные - это особый вид персональной информации о человеке, существенно отличающийся от других типов персональных данных. Федеральный закон от 27 июля 2006 г. № 152-Ф3 "О персональных данных"40 в ст. 3 опредемяет персо-

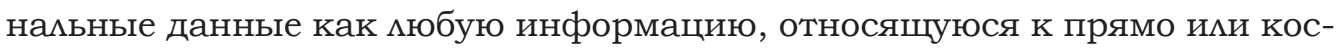

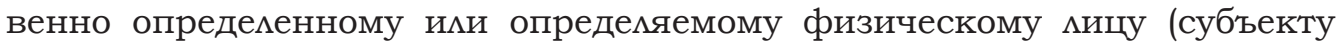
персональных данных). Генетические данные, полученные дмя целей криминалистической базы данных согласно этому Закону, квалифицируются как персональные данные специальной категории, используемые дмя установцения расовой и национальной принадмежности субъекта, полу-

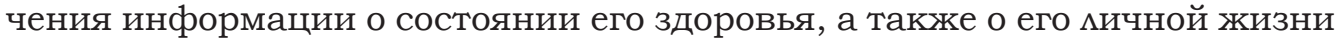
(п. 1 ст. 10). Персональные данные специальной категории разрешается использовать в целях, связанных с осуществлением правосудия (п. 6 ст. 10 Закона), но вызывает опасение то, что органы правопорядка могут использовать сведения из образцов ДНК с другими целями.

Нецелевое использование генетической информации является настолько серьезной проблемой, что в законы о защите данных всех стран Европейского союза были внесены изменения, требующие, чтобы использование данных, собранных полицией, было ограничено целью, дмя которой были собраны доказательства [Wallace, H. M., et al., 2014]. Законодательство многих стран (например, стран Европейского союза, Республики Корея, Малайзии, США и др.) предусматривает санкции за несанкционированный доступ к информации, хранящейся в базах данных ДНК, нарушение ее цемостности, уничтожение и разглашение данных, нецелевое использование ${ }^{41}$.

Вк^ючение подобных гарантий в российское законодательство повысит уверенность общества в том, что геномная информация будет использоваться законно и таким образом, чтобы не ущемлять права человека.

Отдельно нормативно-правового регулирования требуют вопросы, связанные с определением списка организаций, вкАючая организации охраны правопорядка и национальной безопасности, которые будут иметь доступ к базе данных геномной информации. Кроме этого, база может стать незаменимым инструментом дмя изучения генетических особенностей антисоциамьного поведения и виктимности. В этой связи возможность

40 Федеральный закон от 27 июля 2006 г. № 152-Ф3 “О персональных данных" (с изм. на 24.04.2020). URL: http://docs.cntd.ru/document/901990046 (дата обращения: 12.11.2020).

41 Forensic Genetics Policy Initiative. 2017. Establishing Best Practice for Forensic DNA Databases. URL: http://dnapolicyinitiative.org/report/ (дата обращения: 12.11.2020). 
использования хранящейся в ней информации дмя проведения научноисследовательской работы также должна быть законодательно оговорена.

\section{Обсуждение и заключение}

Доказательная ценность генетической информации, используемой дмя идентификации мичности, явцяется одной из самых высоких по сравнению с другими видами доказательств. Даже в случаях, когда правонарушитель не оставиц видимых следов своего пребывания на месте преступмения, он практически всегда оставляет свой генетический материал, по которому его можно идентифицировать. Быстрое раскрытие преступления зачастую прямо зависит от наличия ДНК-профиля возможного правонарушителя в криминалистической базе генетических данных. Намичие такой всероссийской базы ДНК позволит не только эффективно раскрывать преступления, но и значимо сократить затраты, в том числе временнь́іе, на раскрытие преступлений.

Вопросы взятия биологических образцов, регистрации и хранения помученной из них генетической информации прямо связаны с вопроса-

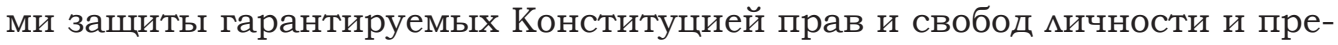
зумпцией невиновности. В этой связи в государстве домжна быть создана надмежащая правовая основа дия ДНК-криминалистики и базы данных ДНК, которая обеспечит как законность использования генетической информации дмя проведения следственных мероприятий, так и законность полученных таким образом доказательств.

Во многих странах, уже использующих базы данных ДНК дмя правоохранительных целей, разработано законодательство, которое регулирует разнообразные вопросы использования ДНК в криминалистике - от типа изымаемого биологического материала и категорий субъектов, генетическая информация которых подмежит регистрации, до дмитемьности сроков хранения и усмовий удамения такой информации.

$\mathrm{K}$ сожалению, ситуация с законодательным регулированием проблем, связанных со сбором и ведением генетического репозитория в России, не идеальна. Принятый более десяти мет назад Федерамьный закон «О государственной геномной регистрации в Российской Федерации" далек от совершенства. Нуждаются в законодатемьном регулировании такие вопросы, как: типы образцов, которые следует брать у субъекта дмя проведения генетической экспертизы; право отказа от их сдачи и ситуации, когда возможно симовое принуждение; круг миц и категории преступлений, подмежащие регистрации; сроки хранения и критерии удаления информации дмя каждой категории миц; правима доступа к генетическим данным и надмежащая их защита. Создание надежной законодатемьной основы дмя поддержания деятельности криминалистической базы генетических данных обеспечит повышение эффективности борьбы правоохранительных органов с преступностью. 


\section{Список исподьзованной Аитературы}

Белов О. А., Белова О. Н. Учет ДНК подозреваемых, обвиняемых и осужденных к $и$ шению свободы: вопросы правовой регламентации // Пенитенциарная наука. 2016. Т. 36, № 4. С. 44-47.

Гостев А. А. По биологическим следам // Полиция России. 2017. № 1. C. 24-27.

Перепечина И. О. Федеральный закон "О государственной геномной регистрации в Российской Федерации": правовые и криминалистические аспекты // Вестник криминалистики. 2010. Вып. 1. С. 16-22. Попова Т. В., Сергеев А. Б. Федеральная база данных геномной информации в системе обеспечения баланса частных и публичных интересов в уголовном судопроизводстве // Юридическая наука и правоохранительная практика. 2017. № 1. С. 132-139.

Butler J. M. Advanced Topics in Forensic DNA Typing: Methodology. Academic Press, 2011. 704 p.

DAMA-DMBOK: Data Management Body of Knowledge. 2nd ed. / DAMA International. New Jersey : Technics Publications : Basking Ridge, 2017. 590 p.

Genetic Testing and the Criminal Law / ed. D. Chalmers. London : UCL Press, 2005. 264 p.

Gottfredson M. R., Hirschi T. A General Theory of Crime. Stanford University Press, 1990. 316 p.

Guillén M., Lareu M. V., Pestoni C., Salas A., Carracedo A. Ethicallegal problems of DNA databases in criminal investigation / Journal of Medical Ethics. 2000. Vol. 26. P. 266-271.

Herkenham D. DNA database legislation and legal issues // Profiles in DNA. 2002. Vol. 5, issue 1. P. 6-7.

Lowe A. L., Urquhart A., Foreman L., Evett I. Inferring ethnic origin by means of an STR profile // Foren. Sci. Int. 2001. Vol. 119, issue 1. P. 17-22.

Machado H., Granja R. DNA Databases and Big Data / Forensic Genetics in the Governance of Crime. Singapore : Palgrave Pivot, 2020. 120 p.

Santos F., Machado H., Silva S. Forensic DNA databases in European countries: is size linked to performance? // Life Sci Soc Policy. 2013. Vol. 9, issue 12. URL: https://doi.org/10.1186/2195-7819-9-12

Schneider P. M., Martin P. D. Criminal DNA databases: the European situation // Forensic Sci Int. 2001. Vol. 119, issue 2. P. 232-238.

Schneider P. M., Prainsack B., Kayser M. The Use of Forensic DNA Phenotyping in Predicting Appearance and Biogeographic Ancestry // Dtsch Arztebl Int. 2019. Vol. 116, issue 51-52. P. 873-880. 
Semikhodskii A. Dealing with DNA Evidence: A Legal Guide. London : Routledge Cavendish, 2007. 200 p.

Wallace H. M., Jackson A. R., Gruber J., Thibedeau A. D. Forensic DNA databases - Ethical and legal standards: A global review // Egypt J Forensic Sci. 2014. Vol. 4, no. 3. P. 57-63.

Williams R., Johnson P. Forensic DNA Databasing: A European Prospective. Interim report, June 2005. 2005. URL: http:/ / community. dur.ac.uk/robin.williams/EU_Interim_Report_2005.pdf (дата обращения: 09.11.2020).

Zedlewski E., Murphy M. B. DNA Analysis for "Minor" Crimes: A Major Benefit for Law Enforcement // NIJ Journal. 2006. 1 January. URL: https:/ / nij.ojp.gov/topics / articles / dna-analysis-minor-crimes-majorbenefit-law-enforcement (дата обращения: 30.06.2020).

\section{References}

Belov, O. A. and Belova, O. N., 2016. DNA registration of suspects, accused and sentenced to imprisonment: issues of legal regulation. Penitentsiarnaya nauka $=$ [Penitentiary Science], 36(4), pp. 44-47. (In Russ.)

Butler, J. M., 2011. Advanced Topics in Forensic DNA Typing: Methodology. Academic Press.

Chalmers, D., ed., 2005. Genetic Testing and the Criminal Law. London: UCL Press.

DAMA International, 2017. DAMA-DMBOK: Data Management Body of Knowledge. 2nd ed. New Jersey: Technics Publications; Basking Ridge.

Gostev, A. A., 2017. [According to biological traces]. Politsiya Rossii= [Russian Police], 1, pp. 24-27. (In Russ.)

Gottfredson, M. R. and Hirschi, T., 1990. A General Theory of Crime. Stanford University Press.

Guillén, M., Lareu, M. V., Pestoni, C., Salas, A. and Carracedo, A., 2000. Ethical-legal problems of DNA databases in criminal investigation. Journal of Medical Ethics, 26, pp. 266-271.

Herkenham, D., 2002. DNA database legislation and legal issues. Profiles in DNA, 5(1).

Lowe, A. L., Urquhart, A., Foreman, L. and Evett, I., 2001. Inferring ethnic origin by means of an STR profile. Foren. Sci. Int., 119(1), pp. 17-22.

Machado, H. and Granja, R., 2020. DNA Databases and Big Data. In: Forensic Genetics in the Governance of Crime. Singapore: Palgrave Pivot.

Perepechina, I. O., 2010. [Federal Law “On State Genomic Registration in the Russian Federation": Legal and Forensic Aspects]. Vestnik kriminalistiki $=$ [Bulletin of Criminalistics], 1, pp. 16-22. (In Russ.) 
Popova, T. V. and Sergeev, A. B., 2017. [Federal database of genomic information in the system of balancing private and public interests in criminal proceedings]. Yuridicheskaya nauka i pravookhranitel'naya praktika $=$ [Legal Science and Law Enforcement Practice], 1, pp. 132139. (In Russ.)

Santos, F., Machado, H. and Silva, S., 2013. Forensic DNA databases in European countries: is size linked to performance? Life Sci Soc Policy, 9(12). Available at: <https://doi.org/10.1186/2195-7819-9-12>.

Schneider, P. M. and Martin, P. D., 2001. Criminal DNA databases: the European situation. Forensic Sci Int., 119(2), pp. 232-238.

Schneider, P. M., Prainsack, B. and Kayser, M., 2019. The Use of Forensic DNA Phenotyping in Predicting Appearance and Biogeographic Ancestry. Dtsch Arztebl Int., 116(51-52), pp. 873-880.

Semikhodskii, A., 2007. Dealing with DNA Evidence: A Legal Guide. London: Routledge Cavendish.

Wallace, H. M., Jackson, A. R., Gruber, J. and Thibedeau, A. D., 2014. Forensic DNA databases - Ethical and legal standards: A global review. Egypt J Forensic Sci., 4(3), pp. 57-63.

Williams, R. and Johnson, P., 2005. Forensic DNA Databasing: A European Prospective. Interim report, June 2005. Available at: <http:// community.dur.ac.uk/robin.williams /EU_Interim_Report_2005.pdf> (Accessed 9 November 2020).

Zedlewski, E. and Murphy, M. B., 2006. DNA Analysis for "Minor" Crimes: A Major Benefit for Law Enforcement. NIJ Journal, 1 January. Available at: <https://nij.ojp.gov/topics/articles/dna-analysis-minorcrimes-major-benefit-law-enforcement> (Accessed 30 June 2020).

\section{Информация об авторе / Information about the author}

Семиходский Андрей Генрихович, $\mathrm{PhD}$, OOO "Медикал Геномикс" (Российская Федерация, 170100, г. Тверь, ум. Жемябова, д. 48)

Andrei G. Semikhodskii, PhD, Medical Genomics LLC (48 Zhelyabova St., Tver', 170100, Russian Federation).

E-mail: andrei@medicalgenomics.ru

Дата поступления рукописи в редакцию издания: 13.01.2021; дата одобрения после рецензирования: 01.02.2021; дата принятия статьи к опубмикованию: 02.02.2021.

Submitted 13.01.2021; reviewed 01.02.2021; revised 02.02.2021. 


\title{
Отрасли и институты права / Branches and Institutions of the Law
}

УДК 347.27

DOI: $10.37399 / 2686-9241.2021 .1 .184-224$

\section{В поисках эффективного правового регулирования европейской ипотеки ${ }^{1}$}

\author{
А. Вударски \\ Европейский университет Виадрина, Германия; Зеленогурский \\ университет, г. Зелена-Гура, Польша \\ wudarski@europa-uni.de
}

\begin{abstract}
Аннотация
Введение. Существование различных систем ипотечного права в каждой из стран - членов ЕС затрудняет трансграничное кредитование и препятствует свободному развитию единого рынка капитала в Европейском союзе. Одним из вариантов решения проблемы могла бы стать единая европейская ипотека (Euromortgage).

Теоретические основы. Методы. В статье представлены результаты современных научных исследований и проанализированы модели европейской ипотеки, предложенные несколькими исследовательскими группами. Автор также освещает развитие и экономическое значение европейского ипотечного рынка и дает описание истории европейской ипотеки. В процессе исследования применялись методы анализа, синтеза, сравнительного правоведения.

Результаты исследования. Обсуждаются документы органов ЕС и позиции стран-членов относительно проекта европейской ипотеки. Основное внимание в исследовании уделяется юридической структуре европейской ипотеки. С учетом различных точек зрения в статье делается попытка сформировать оптимальную модель ипотеки.

Обсуждение и заключение. Проанализированы проблемы дополнительной и независимой ипотеки. Хотя автор высказывает некоторые замечания, в целом он поддерживает идею европейской ипотеки.
\end{abstract}

Ключевые слова: европейская ипотека, европейское право, ипотека, европейский ипотечный рынок, Европейский союз

Благодарности. Публикация статьи осуществляется с любезного согласия автора. Редакция журнала выражает благодарность Яне Владимировне Бергер за профессиональный перевод статьи.

Для цитирования: Вударски А. В поисках эфрфективного правового регулирования европейской ипотеки // Правосудие/Justice. 2021. Т. 3, № 1. C. 184-224. DOI: 10.37399/26869241.2021.1.184-224.

1 Статья написана в рамках программы ВОЗВРАЩЕНИЕ/HOMING Фонда польской науки и стипендии Фонда польско-немецкого сотрудничества. Исследование впервые опубликовано в: Wudarski A. W poszukiwaniu konstrukcji eurohipoteki // Kwartalnik Prawa Prywatnego. 2009. Nr. 1. S. 207-240. 


\title{
In Search of Effective Legal Regulation of European Mortgages
}

\author{
A. Wudarski \\ European University Viadrina, Germany; University of Zielona Góra, \\ Zielona Góra, Poland \\ For correspondence:wudarski@europa-uni.de
}

\begin{abstract}
Introduction. The existence of different mortgage law systems in each of the EU Member States makes cross-border lending difficult and impedes the free development of common capital market in the European Union. One of the solutions to the problem could be a common mortgage for Europe (Euromortgage).

Theoretical Basis. Methods. The article presents the results of academic research up to date and analyses models for a Euromortgage proposed by several research groups. At the same time, the author presents the development and economic importance of a European mortgage market and outlines the history of Euromortgage. In this context, the documents of the EU Institutions and positions of the Member States regarding the project are discussed.

Results. The main focus of the research is the legal structure of the Euromortgage.

Discussion and Conclusion. Taking into consideration different opinions, the article seeks to establish the best model while examining closely the problems of accessory and independent mortgage. Although the author expresses some reservations, he generally promotes the idea of the Euromortgage.
\end{abstract}

Keywords: Euromortgage, European law, mortgage, European Union, Euromortgage market

Acknowledgements. The article is published with the kind consent of the author. The editors of journal thank Yana V. Berger for the professional translation of this article.

For citation: Wudarski, A., 2021. In search of effective legal regulation of European mortgages. Pravosudie/Justice, 3(1), pp.184-224. DOI: 10.37399/2686-9241.2021.1.184-224.

\section{I. Ипотечные кредиты в Европейском союзе}

\section{1. Развитие рынка}

Қ потечные кредиты являются очень важным и динамично развивающимся сегментом европейского рынка капиталов. Стоимость жилищных кредитов в Европейском союзе в 2006 г. составила почти 6 млн евро 2 , а в европейской экономике наблюдается постоянный рост ипотечного долга $^{3}$. Динамика развития этого сегмента рынка, однако, характеризуется существенной разнородностью. Наиболее значительный рост спроса на ипотечный кредит наблюдается в государствах, недавно ставших членами Европейского союза. Принимая во внимание уровень экономического

2 Точные данные: 5713,615 млн евро; источник всех статистических данных: Eurostat, National Central Banks, European Mortgage Federation. URL: http:// www.hypo.org/content/default.asp?PageID $=202$

3 В 2006 году он составим 11,1\%; в 2005 г. - 10,7\%.

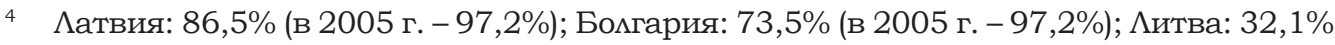
(в 2005 г. - 80,2\%); Румыния: 57,2\% (в 2005 г. - 76,1\%); Эстония: 63,4\% (в 2005 г. 74,5\%); Чехия: 33,9\% (в 2005 г. - 63,4\%); Словения: 43\% (в 2005 г. - 62,7\%). 
развития этих государств, проводимые реформы и объем реализованных и запланированных инвестиций, а также постепенный рост благосостояния населения, в грядущих годах также следует ожидать рост спроса на ипотечные кредиты, хотя его динамику может ослабить кризис на рынке недвижимости в Соединенных Штатах.

На фоне Европы ипотечные кредиты в Польше все еще имеют не очень большое значение. Это проявцяется, в частности, в соотношении ипотечных кредитов и ВВП. В то время как в Европейском союзе в 2006 г. ВВП состав ял в среднем 49\% ${ }^{5}$, в Помьше он едва достигал 8,3\%6. Домя помьского рынка жилищных ипотечных кредитов на европейском рынке также явцяется символической ${ }^{7}$, хоть и характеризуется динамичным развитием $^{8}$. При такой разнице не вызывает удивления то, что банки в государствах, где рост ипотечного долга является небольшим ${ }^{9}$, ищут новые рынки для своих продуктов в иных европейских государствах. Новые источники финансирования, основанные на современных, гибких условиях и решениях, домжны привести к выравниванию и дальнейшему снижению стоимости ипотечного кредита.

\section{Cтоимость кредита}

Стоимость ипотечного кредита в странах Европейского союза была предметом исследований, проведенных Mercer Oliver Wyman ${ }^{10}$ по заказу Европейской ипотечной федерации ${ }^{11}$. В ходе исследования осенью 2006 г. в 13 странах EC ${ }^{12}$ подробно проанализированы факторы, влияющие на действительную стоимость кредита, которую заемщик выплачивает за кредитный период. Во внимание приняты не только размеры процентной ставки, оплаты и провизии, но также расходы, связанные с кредитным

5 В 2005 году этот показатемь составлял 47,5\%. Европейскими мидерами все еще являются: Дания: 100,8\% (в 2005 г. - 94\%); Гоммандия: 98,4\% (в 2005 г. - 97,1\%); Великобритания: 83,1\% (в 2005 г. - 80\%).

6 В 2005 году показатель бым еще ниже и составцяц 6,0\%.

7 Стоимость кредитов в Польше в 2006 г. составила 22,514 млн евро (в 2005 г. 14,646 млн), т. е. 0,00394\% (в 2005 г. - 0,00285\%) европейского рынка.

8 В III квартале 2007 г. стоимость кредитов составила 31,987 млн евро, рост составим 58\% (в 2006 г. - 53,7\%; в 2005 г. - 51,9\%).

9 Например, в Германии, где рост ипотечного домга в 2006 г. составиц около 1,8\% (в 2005 г. - 0,5\%).

10 Mercer Oliver Wyman является мидером в области разработки финансовых стратегий и управления рисками. В компании работают около 1000 сотрудников в 29 офисах, расположенных в 14 государствах в Америке, Европе и Азии (URL: http://www.mow.com).

11 European Mortgage Federation. URL: http://www.hypo.org

12 Чехия, Италия, Португалия, Испания, Греция, Великобритания, Ирландия, Голмандия, Дания, Швеция, Бемьгия, Франция, Германия. 
риском, досрочной выплатой кредита и изменением процентной ставки. На основе этих данных рассчитана предположительная средняя стоимость ипотечного кредита (так называемая adjusted price) в отдемьных странах, после чего проведено сравнение. Согласно представленному в феврале 2007 г. отчету ${ }^{13}$ стоимость кредита составляет от 0,35 до 1,25\%, при этом самая низкая стоимость зафиксирована в Германии (0,35\%), а самая высокая - в Чехии (1,25\%).

Исследования показали, что на немецком рынке долгосрочные ипотечные кредиты с неизменной процентной ставкой предоставцяются на наиболее выгодных условиях. Одной из причин такой ситуации, несомненно, является большая конкуренция, которая дополнительно стимулирует развитие интернет-банков и деятельность заграничных кредиторов ${ }^{14}$. Проводя сравнение с предшествующими исследованиями, которые проводились в 2003 г., можно заметить две тенденции ${ }^{15}$ : сохранение аналогичной разницы между наивысшей и самой низкой adjusted price ${ }^{16}$, а также снижение стоимости кредитов во всех исследуемых государствах ${ }^{17}$. Например, в Германии стоимость кредита в 2003 г. по отношению к 2006 г. снизилась вдвое - с 0,70\% до 0,35\% ${ }^{18}$. Однако, несмотря на повсеместное снижение стоимости ипотечных кредитов, существенные размичия между отдемьными государствами - участниками ЕС все еще сохраняются. Можно предположить, что гармонизация европейского рынка ипотечных кредитов может способствовать устранению этих разцичий. Важным шагом может стать создание единого европейского способа обеспечения ипотечного кредита.

\section{3. О необходимости создания института евроипотеки}

Право залога недвижимого имущества играет важную роль во всех государствах - участниках ЕС. В законодательстве Европейского союза отсутствуют положения, регулирующие данные отношения. Вещные спо-

13 European mortgage markets - 2006 adjusted price analysis. URL: http:/ /www.hypo. org; http: / www.pfandbrief.de

14 Deutsche Immobilieninvestoren profitieren von starkem Wettbewerb / "Adjusted Prices" in Deutschland europaweit am niedrigsten // PresseEcho.de. 2007. 5 February. URL: http://www.presseecho.de/wirtschaft/NA3730936979.htm

15 European Mortgage Federation. P. 4 ff.; PresseEcho.de. 2007. 5 February.

16 Как в 2003, так и в 2006 г. разница составляла 0,64\%.

17 В 2003 году исследование проводимось в 8 государствах: Италии, Португалии, Испании, Вемикобритании, Гомландии, Дании, Франции и Германии.

18 В иных государствах adjusted price в этом периоде снижается; Великобритания: с 1,15\% до 0,68\%; Италия: с 1,34\% до 0,99\%; Гомландия: с 0,97\% до 0,64\%; Испания: с 1,03\% до 0,87\%; Португалия: с 0,95\% до 0,88\%; Дания: с 0,70\% до 0,63\%; Франция: с 0,89\% до 0,36\%, при этом в отчете отмечается, что расчет, произведенный для Франции в 2003 г., содержит ошибку и в результате указанная adjusted price могма быть выше действитемьной.

Pravosudie/Justice. Vol. 3, no. 1. 2021. Translations 
собы обеспечения исполнения обязательств, впрочем, как и иные вопросы вещного права, все еще находятся в ведении внутригосударственного права. Подтверждением этому служит существующий в международном частном праве принцип, согласно которому право собственности и иные вещные права регулируются правом государства, в котором находится вещь (lex rei sitae) ${ }^{19}$. Следовательно, стороны правоотношений не имеют возможности выбрать применимое право при установцении залога недвижимости в качестве вещного способа обеспечения исполнения обязательств [Stöcker, O., 1992, p. 209].

В то же время различия в регулировании залоговых прав в отдемьных государствах - участниках Европейского союза, несмотря на использование схожих понятийных аппаратов, явцяются существенными [Kaindl, R., 1993, p. 277; Wehrens, H., 1992, р. 558]. Ипотека в Помьше ${ }^{20}$, Германии ${ }^{21}$, Австрии 22 или Франции ${ }^{23}$ не может ни при каких условиях рассматриваться как тождественный институт ${ }^{24}$. Разцичия есть не только в самой правовой конструкции, имеющихся формах, способах возникновения, перенесения и прекращения, но также в эффективности обеспечения, а следовательно, в оценке стоимости, принудительном исполнении, порядке удовлетворения требований и т. д. Помностью иной правовой характер [Kostecki, S., 2006, p. 115] имеет также немецкий поземемьный домг ${ }^{25}$.

19 Статья $24 \S 1$ польского Закона о международном частном праве (Prawo prywatne międzynarodowe // Dz.U. 1965. Nr. 46. Poz. 290 (с изм.); § 43 абз. 1 EGBGB (Закон о введении в действие немецкого Гражданского кодекса: Einführungsgesetz zum Bürgerlichen Gesetzbuch vom 18. August 1896 // RGBl. 1896. No. 604 (с изм.); § 32 в связи с $§ 31$ Закона о международном частном праве Австрии (Bundesgesetz vom 15. Juni 1978 über das internationale Privatrecht [iPr-gesetz] // BGB1. No. 304 (с изм.).

20 Статьи 65-112 польского Закона от 6 июця 1982 г. о кадастровых книгах и ипотеке (O ksiegach wieczystych i hipote (обобщенный текст) // Dz.U. 2001. Nr. 124. Poz. 1361 (с изм.) (далее: 3.к.к.и.); об ипотеке в польском праве: [Rudnicki, S., 2002, p. 190 ff.].

21 § 1113-1190 немецкого Гражданского кодекса (Bürgerliches Gesetzbuch, Gesetz vom 18. August 1896 // RGBl. 1896. No. 195 (с изм.) (далее: BGB); об ипотеке в немецком праве: [Wieling, Н., 2001, p. 411 ff.].

$22 \S$ 447-471 австрийского Гражданского кодекса (Allgemeines Bürgerliches Gesetzbuch vom 1. Juni 1811 // JGS. No. 946/1811 (с изм.) (далее: ABGB); об ипотеке в австрийском праве: [Koziol, H. and Welser, R., 2000, p. 336 ff., 350 ff.; Petrasch, F., 1983, p. 407 ff.].

23 Статьи 2393-2425 (ранее ст. 2114-2134) французского Гражданского кодекса (Code civil des Français - Édition originale et seule officielle. Paris: de l'Imprimerie de la République, An Février 1804. 436 р.; далее: CC); об ипотеке во французском праве: [Beysen, E., 2001, p. 256 ff.; Ferid, M., 1971, p. 1071 ff.].

24 Сравнительный анализ польского и немецкого права: [Jaschinska, M., 2004]; немецкого, французского и английского права: [Kircher, S., 2004]; немецкого, французского и швейцарского: [Stöcker, O., 1992].

25 § 1191-1198 BGB; [Kostecki, S., 2006, p. 115 ff.]. 
Эти разиичия существенно усложняют трансграничное перемещение услуг и капитала в Европейском союзе, в том числе в части ипотечных кредитных сдемок, следствием чего явцяется ограничение свободы конкуренции в европейском банковско-финансовом секторе. Кредитор, иными словами, может использовать только те вещные способы обеспечения исполнения обязательств, которые предусмотрены правом, действующим на территории, на которой находится недвижимость.

Банковская оферта, следоватемьно, домжна быть подготовцена индивидуально дмя каждого государства, и ей домжно предшествовать подробное, актуальное, а следовательно, дорогостоящее юридическо-экономическое исследование. Дия заграничных кредиторов по сравнению с мокальными кредиторами возникает ряд дополнитемьных препятствий, которые с учетом финансовой оценки существенно ограничивают их способность конкурировать с мокальными кредиторами, гораздо мучше осведомленными не только о реальной экономической ситуации в стране, но и о действующих правовых нормах. В связи с необходимостью покрытия дополнительных информационно-правовых расходов использование залога заграничного недвижимого имущества в качестве средства обеспечения выплаты ипотечного кредита становится менее привлекательным и менее значимым. В такой ситуации трансграничный рынок ипотечных кредитов в Европейском союзе остается недостаточно развитым, а конкуренция является ограниченной. Несомненно, это отражается на стоимости кредита, обязанность выплаты которого можится на заемщиков.

Возможность исправления сложившейся ситуации усматривается в создании единого европейского права залога недвижимого имущества. Это могмо бы обеспечить банкам возможность использовать выгодный способ обеспечения кредитов, который мог бы аналогично применяться во всех государствах - участниках ЕС. Это также способствовало бы укреплению правопорядка и увеличению конкуренции, которая не существовала бы только в границах государства, а кредитор мог бы финансировать свои инвестиции на более выгодных условиях на территории всего Европейского союза. Это могмо бы послужить импульсом дия динамичного развития экономики, улучшить ее производительность, привести к снижению стоимости инвестиций, а также поспособствовать распространению новых финансовых инструментов.

Попытка создания европейского права залога недвижимости, возможно, также стала бы импульсом дия реформирования внутригосударственного правового регулирования в государствах - участниках ЕС. В частности, это могмо бы способствовать увеличению темпов создания современной системы обеспечения исполнения кредитных обязательств в государствах Центральной и Восточной Европы, а также расширению имевших место до настоящего времени работ над Общей системой под- 
ходов (Common Frame of reference ${ }^{26}$ ) на область вещного права. Принимая во внимание указанные цели, стоит проанализировать предложение по созданию единого европейского права залога недвижимости, часто называемого в $и$ тературе евроипотекой ${ }^{27}$.

\section{II. Историческая справка}

\section{Oтчет Segré}

Идея евроипотеки не явцяется новой - ей уже более 40 ует $^{28}$. Уже с момента возникновения Европейских Сообществ эта идея вызывала живой интерес у представителей науки ${ }^{29}$, практики и у европейских политиков. На выгоды, связанные с введением в государствах - участниках ЕС единого трансграничного права залога недвижимости, указывалось уже в 1966 г. Тогда комиссия ЕЭС создала группу экспертов с целью исследования возможности расширения структуры европейского рынка капиталов. В ноябре группа представима отчет, названный по имени председателя отчетом Segré ${ }^{30}$. В качестве приоритетного задания ученые выбрали сближение и, по возможности, гармонизацию права залога недвижимости в Европейском союзе. Создание однообразного регулирования в этой сфере признано существенным эмементом интеграции европейского рынка капитамов. Отчет ссылается на немецкий опыт и в качестве образца гармонизации указывает немецкий поземельный домг ${ }^{31}$; при этом подчеркиваются плюсы, связанные с гибкостью правового регулирования, обусловленного неакцессорным характером этого способа обеспечения исполнения обя-

26 См.: Draft Common Frame of reference, Interim Outline Edition / ed. Ch. v. Bar, E. Clive, H. Schulte-Nölke. München, 2008, доступный также на сайте: http:// www.law-net.eu/

27 Это наименование уже использовалось в работах Комиссии по вопросам Европейского Экономического Сообщества (КЕЭС), функционировавшей в рамках Международного союза матинского нотариата [Kaindl, R., 1993, p. 278; Wehrens, H., 1992, p. 559 ff.].

28 Короткая историческая справка представлена в: [Stöcker, O., 2006, p. 2 ff.].

29 Евроипотека, в частности в Германии, явцяется предметом многочисленных научных работ, в том числе докторских диссертаций: [Kircher, S., 2004; Kiesgen, Ch., 2004; Stöcker, O., 1992].

30 Официальное наименование отчета: Der Aufbau eines Europäischen Kapitalmarkts, Bericht einer von der EWG-Kommission eingesetzten Sachverständigengruppe (The Development of a European Capital Market). Кроме председателя в работе принимали участие 11 экспертов, являющихся представителями всех государств участников ЕС. Среди них наиболее многочисленными были представители банков, но в работе также принимали участие профессора как представители юридических наук. Профессор Claudio Segré был директором исследований в Генеральном директорате по экономическим и финансовым вопросам Комиссии ЕЭC [Kircher, S., 2004, p. 418, footnote 62].

$31 \S 1191-1198$ BGB.

Правосудие/Justice. T. 3, № 1. 2021. Переводы 
зательств. Авторы отчета обратили особое внимание на преимущества поземельного долга в форме письма [Kircher, S., 2004, p. 419; Stöcker, O., 1992, p. 217]. Отчет Segré не включал проект нормативного акта, поэтому сложно однозначно охарактеризовать объем планируемых в свое время изменений ${ }^{2}$. Отчет оставцяет без ответов много других существенных вопросов. В частности, основываясь на содержащихся в нем данных, невозможно определить, домжна $и$ евроипотека использоваться исключительно дия обеспечения исполнения обязательств, возникающих из международных кредитных сделок, или может также применяться во внутригосударственных правовых отношениях [Kircher, S., 2004, p. 443 ff.], а также домжна $и$ она явцяться дополнительным способом обеспечения исполнения обязательств и, следовательно, функционировать наравне с существовавшими ранее в государствах - участниках ЕС вещными способами обеспечения исполнения обязательств или же стать для них заменой [Kircher, S., 2004, p. 445 ff.].

\section{2. Заключение Института имени Макса Планка в Гамбурге}

Институт сравнительного и международного частного права имени Макса Планка в Гамбурге ${ }^{33}$ согласицся по заказу Комиссии в 1971 г. дать закАючение, касающееся гармонизации права залога недвижимости в ЕЭС. ГАавной целью исследования было определение препятствий на пути $\mathrm{k}$ созданию единого рынка капиталов, а затем - поиск возможных путей их преодоления. Предметом сравнительного анализа стали правовые институты, служащие обеспечению выплаты кредитов с использованием недвижимости [Stöcker, O., 1992, р. 218 ff.]. Созданная в Институте в декабре 1971 г. исследоватемьская группа под руководством проф. Уиьриха Дробнига представила первую часть заключения. Объем исследований включал правовые системы шести государств - участников ЕС ${ }^{34}$. В 1976 году первая часть заключения была дополнена проф. Полом Джексоном в части правового регулирования, принятого в Дании, Ирландии и Великобритании ${ }^{35}$. Вторая часть заключения, которая должна была содержать подробный анализ существующих различий и предможения относительно возможности введения союзного права залога недвижимости в Европе, $\mathrm{k}$ сожалению, не быма составлена.

32 Анализ отчета: [Kircher, S., 2004, p. 442 ff.].

33 Max-Planck-Institut für ausländisches und internationales Privatrecht in Hamburg (http://www.mpipriv.de).

34 Бемьгия, Германия, Франция, Италия, Аюксембург и Гомландия.

35 Оригинальное название: Die Grundpfandrechte in den Rechtsordnungen Dänemarks, Irlands sowie des Vereinigten Königreichs von Großbritannien und Nordirland. Доступ к Заключению можно получить в Институте Макса Планка в Гамбурге, номер документа Rvgl. 17060/100.

Pravosudie/Justice. Vol. 3, no. 1. 2021. Translations 


\section{3. Предложения Международного Союза латинского нотариата}

Евроипотека быма предметом исследований также Commission des Affaires de la Communauté Euorpéenne (КЕЭС) ${ }^{36}$, созданной в рамках Международного союза матинского нотариата $(\mathrm{MC} \Lambda \mathrm{H})^{37}$. В 1983 году комиссия создала рабочую группу, которая под руководством Ганса Джорджа Веренса (Германия) и Эдмонда Грессера (Франция) исследовала правовые возможности создания общего европейского права залога недвижимости. МС $\Lambda \mathrm{H}$ поручиц комиссии провести сравнительный ана-

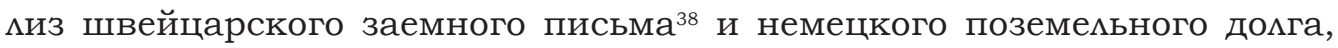
сравнить результаты исследований с правовым регулированием в государствах Европейского союза и на основе полученных данных предпринять попытку разработки основ правового регулирования [Köndgen, J. and Stöcker, O., 2005, p. 112]. В результате проведенных работ 22 мая 1987 г. комиссия представица Совету Министров ЕС проект евроипотеки ${ }^{39}$. Комиссия рекомендовала ввести институт евроипотеки наряду с уже существующими внутригосударственными вещными формами обеспечения исполнения обязательств; евроипотека должна была использоваться прежде всего дия обеспечения исполнения трансграничных кредитных сделок, хоть и не искАючалось ее использование при внутригосударственном кредитовании. В качестве образца была принята модель швейцарского заемного письма ${ }^{40}$.

Евроипотека была определена как неакцессорное право залога недвижимости, которому сопутствует абстрактное обязательство по выплате определенной денежной суммы. В результате мы имеем дело с абстракт-

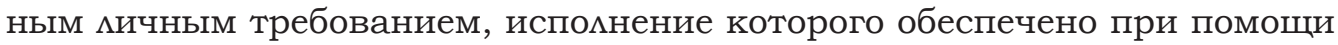
вещи и закреплено на ценной бумаге. Данная конструкция дает двойную гарантию, поскольку собственник обремененной недвижимости

36 КЕЭС была создана в 1967 г. В ее состав входят нотариусы и адвокаты государств - участников ЕС. Ее основной задачей является решение вопросов права Европейского союза.

37 Международный союз матинского нотариата явцяется неправитецьственной организацией, созданной в 1948 г. в Буэнос-Айресе. Его основной задачей является поддержка развития и сотрудничества нотариата в мировых масштабах. В настоящее время Союз объединяет 72 нотариальных сообщества стран. Штабквартира - г. Рим. http:/ /www.uinl.org

38 Статьи 842-846 и ст. 854-874 швейцарского Гражданского кодекса (Schweizerisches Zivilgesetzbuch vom 10. Dezember 1907, SR: 210 (с изм.).

39 Результаты работы комиссии представили R. Kaindl [1993, p. 278 ff.], H. Wehrens [1992, p. 559 ff.], O. Stöcker [1991, p. 538 ff.].

40 [Kaindl, R., 1993, pp. 278, 280; Wehrens, H., 1992, p. 559 ff.; Stöcker, O., 1991, p. 538 ff.]; аргументы в пользу швейцарской модели: [Kiesgen, Ch., 2004, p. 48 ff.]; евроипотека, основанная на швейцарском заемном письме, представцена в работе [Stöcker, O., 1992, p. 279 ff.]. 
несет как имущественную, так и мичную ответственность ${ }^{41}$. Создатели данной концепции полагали, что законодательные органы государств в полной мере (с момента возникновения до момента прекращения) осуществят интеграцию евроипотеки в свою правовую систему [Kaindl, R., 1993, p. 278; Wehrens, H., 1992, р. 560]. В связи с различиями в системах ведения кадастровых книг рекомендовано, например, - с целью обеспечения безопасности правового оборота - ввести официальное, выдаваемое государственным органом подтверждение внесения евроипотеки в реестр и ее позиции по отношению к иным вещным правам, внесенным в реестр. Подтверждение домжно было иметь однообразную форму и отражать правоотношения, существующие во всех государствах-участниках [Kaindl, R., 1993, p. 279; Wehrens, H., 1992, р. 562]. Комиссия также указала, что введение евроипотеки как формы обеспечения исполнения кредитных обязательств домжно быть осуществлено в форме распоряжения [Kaindl, R., 1993, p. 280; Wehrens, H., 1992, p. 562; Stöcker, O., 1991, p. 540].

\section{4. Предложения Союза немецких ипотечных банков в Берлине}

Спустя нескоцько мет, в 1998 г., группа экспертов, действующая под руководством Союза немецких ипотечных банков (СНИБ) ${ }^{42}$, подготовима рекомендации, касающиеся неакцессорного права залога недвижимости, с целью его введения на территории Центральной и Восточной Европы [Wolfsteiner, H. and Stöcker, O., 1998, p. 264 ff.] ${ }^{43}$. На основе данных рекомендаций бым разработан проект закона, который, однако, не относился к конкретному государству [Wolfsteiner, H. and Stöcker, O., 1998, p. 267 ff. ${ }^{44}$. Исходным пунктом дия начала работ над проектом стали прежде всего швейцарское заемное письмо и немецкий поземемьный долг. Согласно проекту недвижимость можно бымо обременить таким образом, что мицу, в поцьзу которого установцено обременение, необходимо будет выплатить за счет недвижимости определенную денежную сумму. Обременение могмо касаться также прав, которые подмежат внесению в реестр наравне с недвижимостью. Залоговое право домжно было возникать на основании записи в кадастровых книгах, дмя чего бымо бы необходимо получение согласия собственника в нотариальной форме; оно также могмо бы быть установ ено в пользу собственника и не прекращалось бы в результате объединения его с правом собственности на недвижимость. В правовом обороте это право выступало бы в форме записи в реестре или в форме

41 О швейцарском заемном письме: [Stöcker, O., 1992, p. 230 ff.].

42 Verband deutscher Hypothekenbanken, в настоящее время: Verband deutscher Pfandbriefbanken (vdp); http:/ / www.pfandbrief.de

43 То же см. в: Deutsche Notar-Zeitschrift (далее: DnotZ). 1999. S. 451 ff.; а также на английском языке: Wolfsteiner H., Stöcker O. A nonaccessory Security Right over Real Property for Central Europe // Notarius International. 2003. P. 116 ff.

44 То же см. в: DnotZ. 1999. S. 460 ff. 
ценной бумаги (документа), и в зависимости от формы его передача могма бы осуществляться в различных формах. Право залога недвижимого имущества, конечно, было бы зависимым от требования, что домжно было бы значительно упростить его применение в банковской практике. В случае обеспечения требования оно не прекращалось бы автоматически в момент удовлетворения требования. Собственник недвижимого имущества, в свою очередь, мог бы требовать возврата права залога или удаления записи о нем из кадастровой книги. Эмементом, связывающим право залога с правом требования, домжен бым быть договор обеспечения исполнения обязательств. Подчеркивая преимущества данной концепции, эксперты признали целесообразной разработку законодатемьного регулирования минимамьных требований к договору обеспечения исполнения обязательств, а в дополнении к проекту рассматривалась возможность ограничить круг заемщиков до миц, подиежащих государственному контролю. Работу над данными рекомендациями впоследствии продомжила испанская исследовательская группа The Eurohypothec ${ }^{45}$, которая в свою очередь, представила результаты исследований группе Collateral, действующей в рамках Forum Group [Köndgen, J. and Stöcker, O., 2005, p. 113].

\section{5. Предложения дискуссионной группы по вопросам ипотечного кредита}

В очередной раз вопросы евроипотеки были проанализированы в 2003 г. созданной Европейской Комиссией дискуссионной группой по вопросам ипотечного кредита (Forum Group on Mortgage Creditt6). Идея введения единого европейского права залога недвижимого имущества получила положительную оценку и была учтена в перечне предмагаемых рекомендаций ${ }^{47}$. Согласно представленному отчету евроипотека не домжна иметь акцессорный характер, она домжна давать возможность обременять недвижимость, обеспечивать выплату трансграничных ипотечных кредитов, характеризоваться простотой перенесения и явцяться надежным средством обеспечения исполнения обязательств в случае банкротства заемщика ${ }^{48}$. Дия защиты интересов заемщика предлагалось заключение между кредитором и собственником обремененной недвижимости гражданскоправового договора, содержащего указание на цемь выбранного способа

45 The Eurohypothec a common mortgage for Europe. URL: http://www.eurohypothec. com/

46 Reference: IP/03/442 (27 March 2003). URL: http://europa.eu/rapid/press ReleasesAction.do?reference=IP/03/442\&format $=$ HTML\&aged=1\&language=EN\&gu iLanguage $=$ en

47 European Communities, the Integration of the EU Mortgage Credit Markets - Report by the Forum group on Mortgage Credit, 2004, Recommendation no. 38, Annex VI (euromortgage). URL: http://www.europa.eu.int

48 Report by the Forum Group on Mortgage Credit, 2004, Annex VI. 
обеспечения ${ }^{49}$. С финансовой точки зрения существенное преимущество данного вида евроипотеки должно было заключаться в возможности беспрепятственной передачи обеспеченного ипотечного требования другому заемщику без необходимости установления новой ипотеки. Дополнительным преимуществом также было то, что несколько кредитов могли бы быть обеспечены одним и тем же имуществом. Бмагодаря такому решению кредиторы могми бы выдавать ипотечные кредиты за границами своего государства на основании единых норм и при повышенной эффективности финансирования. Введение евроипотеки предмагалось поручить комиссии, которая, руководствуясь принципом минимальной гармонизации, должна была издать соответствующую директиву ${ }^{50}$.

\section{6. Нные инициативы и исследовательские группы}

Работы в области интеграции европейского ипотечного рынка, в том чисме касающиеся евроипотеки, ведутся также рядом иных исследовательских групп. Среди них особого внимания заслуживают группа Trento ${ }^{51}$ и Институт при Европейском университете во Фцоренции ${ }^{52}$. Важную роль играет также Европейская ипотечная федерация в Брюсселе, представмяющая интересы банковского сектора ипотечного кредитования в Европе. По ее поручению проводятся регулярные рыночные исследования, цецью которых является установление существующих препятствий на пути к более эффективному функционированию ипотечного кредитования в Европейском союзе, а также определение способов их преодоления ${ }^{53}$. В рамках этой деятельности Федерация выступает с размичными инициативами: организует конференции, встречи, публикует отчеты, прогнозы, в том числе квартальные сравнительные анализы актуальных изменений, происходящих на европейском ипотечном рынке ${ }^{54}$.

\section{7. Основные рекомендации, касающиеся евроипотеки}

Основные рекомендации, касающиеся евроипотеки, были разработаны на встречах, которые по инициативе Союза немецких ипотечных банков

49 Report by the Forum Group on Mortgage Credit, 2004, Recommendation no. 36.

50 Report by the Forum Group on Mortgage Credit, 2004, nb. 192.

51 Trento-Group. URL: http://www.jus.unitn.it/dsg/common\%2Dcore

52 European University Institute (EUI). URL: http://www.iue.it

53 European Mortgage Federation была создана в 1967 г.; представляет интересы как индивидуальных кредиторов, так и их объединений, расположенных в государствах - участниках Европейского Союза. Члены Федерации в общей сложности предоставцяют 75\% жилищных и коммерческих кредитов в Европе.

54 Quarterly Review of European Mortgage Markets. URL: http://www.hypo.org/ Content/ Default.asp?PageID=215 
состоялись в ноябре 2004 г. и в апреле 2005 г. в Берлине. В мероприятиях принимали участие представители нескольких исследовательских групп, занимающихся проблематикой евроипотеки ${ }^{55}$. Результаты их работы были опубликованы в мае 2005 г. Фондом ипотечного кредитования в Варшаве $^{56}$. Содержащиеся в публикации рекомендации определяют евроипотеку как неакцессорное обременение недвижимости, дающее право требовать выплату определенной денежной суммы за счет права собственности на недвижимость ${ }^{57}$. Такое обременение обычно сопровождается договором обеспечения исполнения обязательств (security agreement) ${ }^{58}$ обязатемьственного характера ${ }^{59}$, который определяет цемь предоставления обеспечения и границы реализации права, принадмежащего уполномоченному мицу на основании евроипотеки. Договор не явцяется тождественным договору кредита, хотя оба договора могут быть заключены в форме единого документа ${ }^{60}$. Как в отношении вещного обеспечения, так и в отношении договора обеспечения домжен был применяться lex rei sitae ${ }^{61}$, а евроипотека вносилась бы в реестры недвижимости, существующие в месте ее расположения ${ }^{62}$ и обеспечивающие высокий стандарт безопасности ${ }^{63}$. Рекомендации, содержащиеся в проекте, отметила Европейская Комиссия, которая сослалась на них в Зеленой Книге ипотечного кредитования.

\section{III. Евроипотека в разработках Европейского союза}

\section{1. Зеленая Книга ипотечного кредитования в Европейском союзе}

Европейская Комиссия 19 июля 2005 г. опубликовала Земеную Книгу ипотечного кредитования в Европейском союзе ${ }^{64}$. Среди множества существенных вопросов, касающихся ипотечного кредитования, Комиссия

55 The Eurohypothec: a common mortgage for Europe; Forum group on Mortgage Credit (Collateral); European Land Information Service (EULIS); European University Institute.

56 Basic Guidelines for a Eurohypothec. Outcome of the Eurohypothec workshop, November 2004 / April 2005 / ed. A. Drewicz-Tułodziecka / / Mortgage Bulletin. 2005. No. 21; также: www.ehipoteka.pl/corporate_site/content/download/646/2521/ file/zeszyt_21.pdf

57 Basic Guidelines... B II, 2.1, sentence 1. P. 13.

58 Basic Guidelines... B II, 2.1, sentence 2. P. 13.

59 Подробный анализ договора: Basic Guidelines... B II, 4. P. 15 ff.

60 Basic Guidelines... B II, 2.1, sentence 2, 3. P. 13.

61 Basic Guidelines... B II, 2.3. P. 13.

62 Basic Guidelines... B II, 3.2. P. 13 ff.

63 Basic Guidelines... B II, 7. P. 19 ff.

64 Зеленая Книга. Ипотечное кредитование в ЕС (Текст актуальный дмя Европейской экономической зоны), СОМ(2005) 327.

Правосудие/Justice. T. 3, № 1. 2021. Переводы 
обратила внимание на его обеспечение; сослалась на предпринятые ранее попытки и предложенные проекты разиичных исследоватемьских групп с участием представителей науки и участников рыночных отношений ${ }^{65}$. В качестве одного из аргументов, который приводят сторонники евроипотеки, Комиссия назвала ослабление связи между ипотечным обеспечением и кредитом, что домжно было упростить возникновение и передачу ипотеки, что, в свою очередь, могло бы оказать положительное влияние на рынок ипотечного кредитования, в особенности на финансирование кредитов $^{66}$. В качестве примера Комиссия привела модемь евроипотеки, представменную в Basic Guidelines for a Eurohypothec. Кроме того, неотъемлемой частью Зеленой Книги стали рекомендации Forum Group, которые были представлены в ней в форме приложения. Признание евроипотеки одним из важных инструментов, служащих росту эффективности и конкурентоспособности европейского рынка ипотечных кредитов, стоит считать важным шагом на пути к реализации этой идеи ${ }^{67}$.

\section{2. Консультативные точки зрения, касающиеся евроипотеки}

Публикация Земеной Книги дала начало обширному консультационному процессу, в рамках которого свои позиции заявили не только государства участники ЕС, но также и органы Европейского союза, государственные учреждения, представители банковского и научного сообществ ${ }^{68}$. Подведение итогов первого этапа консультаций завершилось публикацией Комиссией документа Feedback on the Consultation on the Green Paper on Mortgage Credit 2006 6 . Согмасно его содержанию концепцию евроипотеки поддержами всего 19\% финансовых учреждений, 31\% государств - участников ЕС ${ }^{70}$ и

65 Земеная Книга, п. (48).

66 Земеная Книга, п. (47).

67 Эта оценка не изменилась в связи с замечаниями Комиссии относительно необходимости проведения дополнительных консультаций и анализа, в том числе по вопросу окончательного выбора подходящих инструментов; Земеная Книга, п. (3), (48).

68 Заключения доступны на сайте: http://ec.europa.eu/internal_market/finservicesretail/home-loans/comments_de.htm

69 Feedback on the Consultation on the Green Paper on Mortgage Credit 2006, MARKT/ H3/JR D(2006), Brussels, 23 May 2006. URL: http:/ / ec.europa.eu/internal_market/ fin-services-retail/docs/home-loans/feedback_gp-en.pdf

70 Концепцию евроипотеки поддержало в том числе Правительство Польши. Однако в его заключении указывалось, что введение евроипотеки должно быть закАючительным этапом объединения европейского рынка ипотечного кредитования. При этом отмечалось, что "в настоящее время евроипотека как правовой институт с многолетней традицией, прочно закрепившийся в правовых системах всех государств - участников ЕС, может так же хорошо функционировать на основе мокального права каждого государства - участника ЕС, при условии 
43\% прочих субъектов рынка ${ }^{71}$. Аргументируя свою позицию, сторонники евроипотеки указывали на давно известные аргументы. В первую очередь подчеркивалось, что гибкая ипотека неакцессорного характера послужит развитию конкуренции, снизит процентные ставки по ипотечным кредитам, тем самым создавая более благоприятные кредитные усмовия дмя клиентов (потребителей) и способствуя интеграции европейского рынка.

Однако большинство исследователей подходими к данному вопросу с осторожностью. Они указывали на необходимость детального анализа концепции евроипотеки и в итоге не высказали ни положительного, ни отрицательного мнения. Такую позицию заняли 69\% финансовых учреждений, 100\% потребителей, 38\% государств - участников ЕС и 43\% прочих субъектов рынка ${ }^{72}$.

Полученные заключения обратили внимание Комиссии на ряд существенных вопросов. Так, предлагалось исследовать влияние и связь евроипотеки с внутригосударственным правом, в частности там, где присутствовала бы необходимость введения изменений. Важными признаны предможение проанализировать влияние евроипотеки на потребителей, а также поиск ответа на основной вопрос: будет $\Lambda$ евроипотека реальным решением существующих проблем? Кроме того, некоторые закцючения, в частности поступившие от государств - участников ЕС, указывали на необходимость подробного анализа компетенции Европейского союза в части регулирования данного вопроса, в том числе в контексте принципа субсидиарности.

Консультации выявили разногласия также в вопросе направлений дальнейшей деятельности. Сторонники евроипотеки считают, что Европейский союз домжен разработать юридические и экономические рекомендации по данному вопросу. Среди сторонников более глубокого анализа вопроса некоторые субъекты рынка утверждают, что Комиссия домжна разработать бомее проработанный проект и провести юридическо-экономический анализ; в то же время другая группа считает, что субъекты, являющиеся сторонниками евроипотеки, должны более подробно представить свои предложения и комплексно рассмотреть ее влияние на европейский рынок.

Одним из кАючевых вопросов евроипотеки, ставшим предметом множества комментариев, быц вопрос ослабления связи между обеспечением и кредитом. Этот вопрос также бым предметом критических оценок и опасений скептиков, среди которых $12 \%$ составцяли финансовые учреждения, 31\% - государства - участники ЕС и 14\% - иные субъекты рынка.

создания исправно работающей системы обмена информацией о правовом статусе недвижимости, единой дмя всего ЕС"; данное мнение приложено к письму в Министерство финансов от 23 ноября 2005 г. № FI/PTS/IE-3503/2005, с. 11 и след. URL: http://ec.europa.eu/internal_market/finservices-retail/docs/homeloans/comments/ms-pl_minfin-pl.pdf

71 Feedback... 8.2. S. 45.

72 Feedback... 8.2. S. 45 
Данный вопрос также поднимался в отзывах, в которых не было однозначно опредемено отношение к вопросу евроипотеки. В частности, ставился вопрос, явцяется $\Lambda и$ неакцессорная модемь подходящим решением дия Европы. В данном контексте рекомендовалось проведение сравнительного анализа акцессорной и неакцессорной форм обеспечения с цемью опредемения наиболее подходящего варианта.

\section{3. Работа правительственной группы экспертов по вопросам ипотечного кредитования}

В связи с многогранностью проблематики принято решение продолжить консультации на правительственном уровне. 31 мая 2006 г. группа правительственных экспертов по вопросам ипотечного кредитования получила рабочую документацию, содержащую вопросы, касающиеся проблематики Зеленой Книги ${ }^{73}$. Среди вопросов, представ енных в данной документации, отсутствует пробцематика евроипотеки. Однако поиск ответов на содержащиеся в ней вопросы ${ }^{74}$, а также тесное сотрудничество в рамках созданной группы домжны, по мнению Комиссии, позволить собрать необходимую информацию относительно функционирования кредитного рынка в государствах - участниках ЕC и способствовать углубцению и всестороннему анализу всех вопросов, связанных с созданием единого рынка ипотечного кредитования в Европейском союзе.

\section{4. Резолюиия по вопросу ипотечного кредитования в Европейском союзе}

Вопросом евроипотеки заинтересовался также Европейский Парламент. Экономический и валютный комитет опубликовал 19 октября 2006 г. отчет по вопросу ипотечного кредитования в Европейском союзе ${ }^{75}$. Отчет содержит проект Резолюции, в которой Европейский Парламент призывает Комиссию провести анализ препятствий, усложняющих трансграничное предостав ение кредитов, и продомжить исследование потенциала евроипотеки как инструмента, обеспечивающего исполнение обязательств с учетом сопутствующих ей гарантий ${ }^{76}$. Принимая 14 ноября

73 Working Document, Government Expert Group on Mortgage Credit (GEGMC). URL: http: / / ec.europa.eu/internal_market/finservices-retail/docs/home-loans/gegmc/ gp_followup-en.pdf

74 Позиции государств - участников EC: http://ec.europa.eu/internal_market/ finservices-retail/home-loans/gegmc_comments_de.htm

75 Отчет № 2006/2102 (INI), итоговая версия: A6-0370/2006. URL: http://www. europarl.europa.eu/sides /getDoc.do?pubRef=- / EP/ /TEXT+REPORT+A6-20060370+0+-DOC+XML+VO//PL

76 Отчет № 2006/2102 (INI), итоговая версия: А6-0370/2006. Пункт 22 проекта Резолюции Европейского Парламента по вопросу ипотечного кредитования в Европейском союзе $(2006 / 2102$ (INI), с. 8.

Pravosudie/Justice. Vol. 3, no. 1. 2021. Translations 
2006 г. Резолюцию77, Европейский Парламент уточнил, что речь идет о гарантиях, которые необходимы для установления и использования евроипотеки, в частности в отношении обеспечения публичного доступа к документам и последствий для третьих миц. В Резолюции содержится рекомендация исследовать соотношение евроипотеки и иных вещных способов обеспечения исполнения обязательств и обратить внимание на ее связь с правом требования; также указывается на необходимость исследования правовых последствий частичного или полного прекращения обеспеченного права требования, изменения основания его оценки или переноса этого права как для кредиторов, так и для третьих $\Lambda и ц^{78}$. Евроипотека при этом названа факультативным общеевропейским инструментом дмя упрощения трансграничной кредитной деятельности, над чем еще необходимо работать ${ }^{79}$.

Обращено внимание Европейской Комиссии на необходимость опредеиить инструменты, которые могли бы упростить перенос ипотечных кредитов, в том числе исследовать существующие в праве препятствия, замедляющие развитие европейского рынка ипотечного кредитования ${ }^{80}$. Одновременно Европейский Парламент призывает развивать на государственном уровне механизмы, позволяющие использовать так называемую возобновмяемую ипотеку ${ }^{81}$. Наконец, была отмечена потребность обеспечить равный, не дискриминирующий доступ к информации о клиентах и о рынке недвижимости, в том числе к информации об ипотечном обеспечении и о праве собственности. Широкий доступ к этим данным при условии сохранения конфиденциальности был признан ключевым фактором, который скужит обеспечению равных шансов кредиторам, входящим на рынок ${ }^{82}$.

Результаты всех предпринятых действий в рамках Европейского союза, содержащие в том числе как итоговые выводы, сформулированные в

77 Резолюция Европейского Парламента по вопросу ипотечного кредитования в Европейском союзе (2006/2102(INI), итоговая версия A6-0370/2006. URL: http: / / www.europarl.europa.eu / si-des / getDoc.do?type=TA\&reference=P6-TA2006-0487\&language $=$ PL\&ring $=$ A6-2006-0370

78 Пункт 23 Резолюции Европейского Парламента по вопросу ипотечного кредитования.

79 Обоснование проекта Резолюции Европейского Парламента по вопросу ипотечного кредитования, с. 15.

80 Пункты 23 и 31 проекта Резолюции Европейского Парламента по вопросу ипотечного кредитования, с. 9; п. 30 Резолюции Европейского Парламента по вопросу ипотечного кредитования, с. 7.

81 Пункт 25 Резолюции Европейского Парламента по вопросу ипотечного кредитования, с. 6.

82 Пункт 35, 36 и 40 Резолюции Европейского Парламента по вопросу ипотечного кредитования, с. 7 и след., а также обоснование проекта Резолюции Европейского Пармамента по вопросу ипотечного кредитования, с. 16. 
результате консультаций, так и предможения, домжны были быть объединены в Белой Книге, которая была опубцикована по окончании процесса консумьтаций 18 декабря 2007 г. ${ }^{83}$ Однако документ не содержит анонсированных действий в части евроипотеки ${ }^{84}$.

\section{IV. Правовая конструкция евроипотеки}

Правовая сущность евроипотеки была и явцяется причиной многочисленных дискуссий как догматического, так и политико-правового характера. С учетом многогранности данной проблематики дальнейшее исследование необходимо ограничить анализом одного из вопросов. В научной дискуссии на первое место ставится вопрос, касающийся правовой формы евроипотеки. Здесь сталкиваются два противоположных мнения: первое отстаивает неакцессорный характер евроипотеки, в то время как второе высказывается в пользу акцессорной конструкции ${ }^{85}$.

\section{1. Евроипотека как неакчессорное право}

А) Основные положения

Отдельные положения концепций евроипотеки, содержащихся в указанных выше инициативах и проектах, отмичаются друг от друга. Их общей чертой является, однако, теория, согласно которой в будущем европейское право залога недвижимости домжно иметь неакцессорный характер, а следовательно, должно быть обособлено от требования, которое оно обеспечивает. Как обеспеченное право (требование), так и обеспечивающее право (евроипотека) в таком случае были бы самостоятельными правовыми явцениями, в результате чего могли бы независимо передаваться другим мицам, а прекращение права требования не влекло бы за собой прекращение евроипотеки.

83 Белая Книга, касающаяся интеграции рынков ипотечного кредитования в ЕС, KOM(2007) 807 итоговая версия. URL: http://eur-lex.europa.eu/LexUriServ/ LexUr iServ.do?uri=CELEX: 52007DC0807:PL:NOT

84 «<..> Относительно права, применимого к обеспечению ипотечного кредита, Комиссия не находит причины дмя отступления от утвердившегося принципа применения права государства, в котором находится недвижимость <...». (Белая Книга, касающаяся интеграции рынков ипотечного кредитования в ЕС, п. 4.1 in fine, c. 10).

Научную дискуссию, касающуюся (не)акцессорного характера евроипотеки, стоит рассматривать исключительно как один из элементов необычайно сложного целого. Представцяется, что не менее значимыми явцяются более глубокие рассуждения, касающиеся множества иных вопросов, впрочем, частично обсуждаемых в митературе по данной теме. Речь идет, например, о компетенции Европейского союза заниматься вопросами вещного права, обеспечения одинаковой интерпретации норм, регулирующих евроипотеку, а также о возможности их интеграции в правовые системы государств - участников ЕС.

Pravosudie/Justice. Vol. 3, no. 1. 2021. Translations 
Отделение права залога от обеспеченного им требования имемо бы исключительно техническое значение. На место акцессорности должен был прийти договор, который определял бы цель предоставления обеспечения, его правовое основание (cause) $)^{86}$ и был бы связующим эмементом между обеспеченным требованием и обеспечивающей его евроипотекой. Таким образом, комплексно правовые отношения домжны были бы состоять из трех элементов: кредитного договора, евроипотеки и договора обеспечения.

Последствия применения такой конструкции следует рассматривать в двух аспектах. Во внешних отношениях она предоставица бы уполномоченному на основании евроипотеки неограниченные возможности по ее использованию. В частности, уполномоченный не был бы обязан доказывать существование права требования, его размер, наступцение срока исполнения. Во внутренних отношениях уполномоченный на основании евроипотеки был бы связан положениями, содержащимися в договоре обеспечения. Это ограничивало бы его возможности по использованию евроипотеки и защищало бы собственника обремененной недвижимости от змоупотребцений, в частности от двойной опматы. Обеспечивающий договор, на основании которого уполномоченный в связи с установлением евроипотеки обязуется перед предоставцяющим обеспечение реализовать предоставленное ему право в границах, указанных в договоре, имел бы доверительный характер ${ }^{87}$. В немецком праве, являющемся основой данной конструкции, такой договор не вписывается в кадастровые книги [Jaschinska, M., 2004, p. 139; Eickmann, D., 1997, § 1191, p. 1929, nb. 41] и не требует соблюдения особой формы, хотя на практике обычно заключается в письменной форме [Jaschinska, M., 2004, p. 140; Eickmann, D., 1997 , § 1191, p. 1929, nb. 31]. В таком случае возникают сомнения, по-

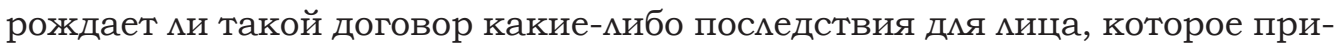
обретает евроипотеку (цессионария), действуя при этом добросовестно ${ }^{88}$.

Отдавая себе отчет в том, какой риск вцечет за собой такое решение на европейском уровне, в частности в государствах, для которых данная конструкция явцяется чуждой, некоторые сторонники неакцессорности евроипотеки склоняются к разработке законодательного регулиро-

86 В связи с этим договор обеспечения называют pactum de hypothecando; [Kaindl, R., 1993, p. 279; Wehrens, H., 1992, p. 561].

87 Данной конструкции сопутствует предложение по созданию европейского поверенного права, основанного на немецкой конструкции; ср.: [Stöcker, O., 2006, p. 3].

88 В немецком праве можно предъявить возражения на основании договора обеспечения также в споре против мица, которое приобрело поземельный долг. Однако если данные возражения не были вписаны в кадастровую книгу, а покупатель действовал добросовестно, ипотечный должник утрачивает возможность ссылаться на них (§ 1157 преди. 2 BGB) [Wieling, H., 2001, p. 476]. 
вания договора обеспечения [Stürner, R., 1992, p. 387 ff.]. При этом подчеркивается, что при создании евроипотеки необходимо принимать во внимание интересы потребителя и нельзя ограничивать их исключительно до стоимости кредита. Следовательно, вместе с евроипотекой домжны быть созданы правовые рамки дия договора обеспечения ${ }^{89}$, что необходимо, поскольку обострение конкуренции на рынке ипотечного кредитования может спровоцировать, особенно на начальном этапе, тенденцию к предостав ению рисковых кредитов ${ }^{90}$. С этим тесно связан риск формирования обеспечивающего договора в свободной форме, что может противоречить интересам потребителя [Stürner, R., 1992, p. 387 ff.]. Регумирование обеспечивающего договора не домжно быть передано в руки законодательных органов государств. Немецкое право не исчерпало своих возможностей развития, а опыт небольшого государства, каким явмяется Швейцария, не может быть распространен на такое большое экономическое пространство, каким явцяется Европейский союз. Поэтому остается единственный выход - создание евроипотеки с законодательно урегулированным договором обеспечения, который бым бы субстратом гибкой акцессорности и гарантирова^ бы собственнику достаточную правовую защиту, в том числе перед цессионарием [Stürner, R., 1992, p. 388]. В свою очередь, отдельного анализа требует соотношение договора обеспечения и евроипотеки в контексте принципа каузальности и абстрактности сдемок [Köndgen, J. and Stöcker, O., 2005, p. 114 ff.; cp.: Pisuliński, J., 2001, p. 12 ff.].

В интересах потребителей рассматривается также возможность ограничения использования неакцессорной евроипотеки дмя обеспечения кредитов, предоставляемых исключительно кредитными учреждениями (банки, страховые компании, государственная казна) [Wolfsteiner, H. and Stöcker, O., 1999, p. 454; Wolfsteiner, H. and Stöcker, O., 1998, p. 265; Wehrens, H., 1992, p. 561]. Некоторые исследователи даже отмечают необходимость представцения составценного сторонами договора обеспечения нотариусу с целью проверки его содержания и информирования о правовых последствиях [Kaindl, R., 1993, p. 279; Wehrens, H., 1992, p. $561 \mathrm{ff}$.$] .$

В отношении вопросов, касающихся возникновения, переноса, формы и видов евроипотеки, концепции в основном опираются на конструкцию немецкого поземельного долга ${ }^{91}$, который наряду со швейцарским заемным письмом в течение многих мет неизменно является исходной модемью будущей евроипотеки.

89 Проект правового регулирования договора, опредемяющего цель предоставцения обеспечения, представиц Ch. Kiesgen [2004, p. 223 ff.].

90 Подтверждением этому служит кризис на американском рынке кредитов с низкой надежностью (subprime).

91 О немецком поземельном долге см., например: [Wieling, H., 2001, p. 461 ff.]. 


\section{В) Экономические преимушества}

Аргументом в пользу принятия такой правовой конструкции явцяется ее востребованность в экономических отношениях, проверенная на немецком рынке, где она полностью вытеснила традиционную ипотеку $^{92}$. Неакцессорная евроипотека была бы для кредиторов (банков) очень удобным и надежным средством обеспечения права требования; надежны процесс ее возникновения (возникает независимо от требования), ее существование (изменение права требования не вцияет на ее существование), перенос (явцяется независимой, не связанной с требованием), и благодаря этому она мегко рефинансируется [Kaindl, R., 1993, p. 279; Wehrens, H., 1992, p. 561]. Это дает возможность ее повторного и многократного использования с целью обеспечения требований, возникающих на основании различных правоотношений, без необходимости установления нового обеспечения ${ }^{93}$.

Евроипотека могла бы быть также установлена в пользу собственника недвижимости (евроипотека собственника), который мог бы таким образом осуществцять "резервацию" обеспечения и впоследствии использовать

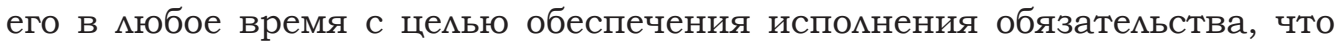
могмо бы существенно упростить получение нового кредита [Kaindl, R., 1993, p. 279; Wehrens, H., 1992, p. 560 ff.; Stöcker, O., 1991, p. 538].

Особенной простотой в переносе характеризовалась бы евроипотека, установ енная в форме письма. Дия ее переноса не требовалось бы внесение записи в кадастровую книгу, достаточно было бы передать письмо покупателю. При этом подчеркивается, что с точки зрения защиты потребителя собственник обремененной евроипотекой недвижимости не был бы в менее выгодной ситуации в сравнении с обременением недвижимости "внутригосударственной" ипотекой в настоящее время ${ }^{94}$.

Преимущество неакцессорного обеспечения перед акцессорным, следовательно, усматривается прежде всего в возможности более гибкого формирования кредитных отношений. Его сторонники указывают на то, что ипотечные кредиты в настоящее время неустанно изменяются; могут предоставцяться и обеспечиваться несколькими субъектами, используются дия обеспечения эмиссии ценных бумаг, делятся, переносятся, продаются. Связанная с этим диверсификация рисков, рефинансирование, а также оптимизация структуры собственного капитала требуют постоянных изменений в портфеле ипотечных кредитов. В свою очередь, ситуации, когда один банк предоставцяет клиенту кредит и обеспечивает его выплату ипотекой, установленной на одном объекте недвижимого иму-

$92 \mathrm{~K}$ вопросу, почему поземельный домг вытеснил ипотеку из хозяйственного оборота Германии: [Stürner, R., 1992, р. 380].

93 Графическое выражение возможности использования неакцессорной евроипотеки: [Luckow, А., 2005, C-1, p. 24 ff.].

94 Cp.: [Stöcker, O., 2006, p. 3]. 
щества, а впоследствии в период кредитования данное положение не изменяется, встречаются все реже [Stöcker, O., 2006, p. 3].

Принимая во внимание происходящие изменения, традиционное средство обеспечения кредитов, каким является акцессорная ипотека, не явмяется настоцько эластичным, чтобы соответствовать потребностям современного финансового рынка; в частности, она не может использоваться в его новых структурах. В то же время неакцессорная ипотека была бы особенно востребована при предоставцении синдицированных кредитов, кредитов с плавающей процентной ставкой, в иностранной валюте, при секьюритизации и реструктуризации долга, а также при обеспечении инвестиций, финансируемых поэтапно и через посредников ${ }^{95}$.

Такая форма обеспечения будет выгодна также дмя заемщика (потребителя). Ее преимущества видны, в частности, при обеспечении нового кредита. Неакцессорная конструкция позволяет избежать существенных расходов, связанных с миквидацией старой и установлением новой ипотеки, а также с установлением дополнительных, часто небезопасных форм обеспечения [Wehrens, H., 1992, p. 561].

\section{2. Еөроипотека как акиессорное право}

\section{А) Понятие акиессорности}

Попытки введения в Европейском союзе неакцессорного обеспечения за счет недвижимого имущества до настоящего времени не принесли жемаемых результатов. В этой связи все чаще слышны высказывания, что евроипотека домжна принять форму акцессорного права [Wachter, T., 1999, p. 49 ff.; Habersack, M., 1997, p. 857 ff.]. Акцессорность в "чистом" виде означает такое отношение зависимости одного права от другого, при котором зависимое право (ипотека) не может возникнуть и существовать без основного права (право требования), а его прекращение влечет за собой прекращение зависимого права. Требование, обеспеченное ипотекой, не может переноситься без ипотеки, а ипотека не может переноситься без требования, исполнение которого она обеспечивает. Следствием акцессорности также явцяется принцип, согласно которому соб-

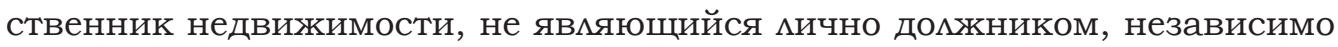
от того, какие возражения он может предъявить ипотечному кредитору, правомочен предъявцять такие же возражения, какие может предъявить непосредственный домжник, в том числе и те, от которых домжник отказался после установления ипотеки. Эта зависимость также касается объема и содержания требования, а также возможности его удовлетворения в рамках исполнительного производства ${ }^{96}$. Зависимое право, таким обра-

95 Cp.: [Luckow, A., 2005, C-1, p. 29 ff.].

96 О размичных сторонах акцессорности: J. Pisuliński [2005b, p. 554 ff.], S. Kircher [2004, p. 41 ff.], M. Habersack [1997, p. 862], D. Medicus [1971, p. 498 ff.]. 
зом, не может существовать самостоятельно и остается тесно связанным с основным правом, которое оно обеспечивает.

В) Акиессорность в европейской правовой культуре

a) Римское право

Сторонники такой конструкции евроипотеки в первую очередь приводят историко-правовые аргументы ${ }^{97}$. Свои истоки принцип акцессорности берет в римском праве [Wołodkiewicz, W. and Zabłocka, M., 2005, nb. 119 ff.; Habersack, M., 1997, p. 860; Becker-Eberhard, E., 1993, p. 128 ff., 165 ff.; Wegan, J., 1958, p. 156 ff.]. Существует единство мнений относительно того, что уже в классическом римском праве, по крайней мере в отношении fideiussio98, существовали принципы, обосновывающие понятие акцессорной зависимости [Wołodkiewicz, W. and Zabłocka, M., 2005, nb. 334]. Относительно происхождения самого понятия акцессорности следует отметить, что, хотя fideiussio и pignus неоднократно назывались "accessiones" principalis obligatio, а следовательно, дополнением к главному праву, они не имели таких последствий, какие влекут за собой современные поручительство и залог [Becker-Eberhard, E., 1993, p. 127 ff.]. Одновременно как дмя fideiussio, так и дмя pignus существовали принципы, которые accessiones в разцичной мере придавали акцессорный характер по отношению к обеспеченному обязательству. Поручительство могмо быть предостав ено на меньшую, но не на бо́цьшую сумму, чем основной долг. Поручитель мог предъявяять такие же возражения, как и основной должник, а прекращение основного обязательства вцекло за собой прекращение поручительства. Аналогично функционировало право залога.

Конечно, римские юристы признавали акцессорный характер поручительства и права залога только в определенных ситуациях. То есть их понимание акцессорности было очень гибким. Поручительство и залог хоть и были акцессорными правами, но не в силу их природы, а в той мере, в какой это соответствовало их функции [Habersack, M., 1997, p. 860]. В период расцвета пандектного права акцессорность стала правовым принципом и оказала вцияние на развитие современных правовых систем ${ }^{99}$.

\section{b) Франиузское право}

На принципе акцессорности были основаны крупнейшие кодификации гражданского права, имевшие место на рубеже XVIII и XIX вв. Среди них в хронологическом порядке на первом месте необходимо указать Code civil (CC). Французский Гражданский кодекс с 1804 г. с самого на-

97 О развитии ипотеки как акцессорного права: [Wegan, J., 1958, p. 152 ff.].

98 Fideiussio было единственной формой поручительства, признанной и зафиксированной в Corpus iuris Юстиниана [Habersack, М., 1997, p. 860].

99 О развитии ипотеки в немецком и австрийском праве под вмиянием римского права: [Wegan, J., 1958, p. 158 ff.]. 
чала сформировал ипотеку как право искцючительно акцессорного характера $^{100}$. В такой форме ипотека первоначально домжна была использоваться прежде всего в качестве средства обеспечения исполнения крат-

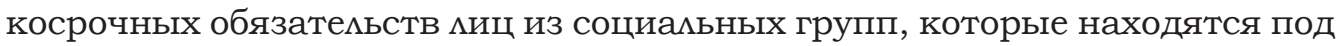
особой защитой, и не предназначалась дмя обеспечения долгосрочных кредитов [Kircher, S., 2004, p. 63].

Во французском праве до сегодняшнего дня не существуют неакцессорные формы вещного обеспечения; французскому праву неизвестна также ипотека собственника и ипотека в форме письма. Французское право, однако, допускает определенные исключения из правила акцессорности ${ }^{101}$. Здесь необходимо указать, в частности, на введенную распоряжением от 24 марта 2006 г. ${ }^{102}$ новую форму ипотеки hypothèque rechargeable ${ }^{103}$, которая дает возможность обеспечения новых обязательств, о которых не было известно и которые даже не существовали в момент ее установления ${ }^{104}$. При этом права требования не обязательно домжны принадмежать одному и тому же кредитору ${ }^{105}$.

\section{c) Австрийское право}

Австрийский Всеобщий гражданский кодекс 1811 г. (ABGB) ${ }^{106}$ до сегодняшнего дня остается верным принципу акцессорности ${ }^{107}$. Хотя австрийской кодификации также чужды неакцессорные вещные способы обеспечения исполнения обязательств за счет недвижимого имущества, необходимо признать, что кодификация не рассматривает акцессорность как абсолютную догму права. В австрийском праве можно найти ряд искиючений, введенных в более позднем периоде ${ }^{108}$. Существующая

100 Статьи 2114-2134 (в настоящее время см. ст. 2393-2425) СС.

101 Cp.: Mouly Ch., Jacob F. B: Juris-Classeur Civil Code art. 2114 á 2117 á art. 2284 á 2488. Paris, 2002. Art. 2114 á 2117, Hypothèques, В. - Limites, тезис 163 и далее.

102 Ordonnance no 2006/346; на французском, английском, испанском языках - доступны на сайте: http:/ /www.legifrance.gouv.fr/

103 Статьи 2422-2424 CC.

104 См.: [Leutner, G. and Lehberg, T., 2006, p. 817 ff.; Klein, Ch. and Tietz, S., 2007, p. $105 \mathrm{ff}$.$] .$

105 Cм.: Kampf A. Frankreich reformiert das recht der persönlichen und dinglichen Sicherheiten. URL: http://www.bfai.de/DE/Content/_SharedDocs/Links-Einzel dokumente-Datenbanken/fachdokument.html?fIdent=MKT20060818105802

106 Краткая история создания ABGB: [Koziol, H. and Welser, R., 2000, p. 9 ff.].

107 Об акцессорности австрийского права залога недвижимости: [Wegan, J., 1958, p. 159 ff., 163 ff.].

108 Ср. § 469, 470 предм. 2, 1446 ABGB; § 14 п. 2 австрийского Закона о кадастровых книгах от 2 февраля 1955 г. (Bundesgesetz vom 2. Feber 1955 über die Grundbücher [Allgemeines Grundbuchsgesetz 1955] // BGBl. 39; BGB1 I 2002/76) (далее- GBG). 
в настоящее время австрийская конструкция ипотеки, проверенная временем и закрепившаяся в судебной практике, идет навстречу потребностям хозяйственного оборота и позволяет настолько эластично формировать правовые отношения, что в Австрии нет необходимости введения неакцессорного права залога недвижимости по образцу немецкого поземельного долга ${ }^{109}$. Этот факт является знаменатемьным также в связи с тем, что эти государства близки с точки зрения истории, кумьтуры и языка ${ }^{110}$.

\section{d) Немеикое право}

И в Германии акцессорность существенно повцияла на работы по кодификации Гражданского кодекса (BGB) [Becker-Eberhard, E., 1993, p. 104 ff.]. Немецкие кодификаторы не отказались от принципа акцессорности; более того, появимись такие положения, содержащие данный принцип, как поручительство (§ 765-778 BGB), залог движимого имущества (§ 1204-1259 БГБ), ипотека (§ 1113-1190 BGB $)^{111}$. Присутствие принципа акцессорности, бесспорно, было обоснованным, хотя немецкий законодатель с целью обеспечения сознательно установиц искиючения из данного правила ${ }^{112}$. Они были обусловлены развитием экономических отношений в период, когда проводимась немецкая кодификация ${ }^{113}$.

\section{е) Голландское право}

Акцессорный характер вещных способов обеспечения исполнения обязательств не бым чертой, характерной исключительно для кодификаций XIX в. Он стал также одним из главных принципов гомландского Гражданского кодекса (Burgerlijk wetboek, BW) [Wachter, T., 1999, р. 63 ff.; Habersack, M., 1997, p. 861 ${ }^{114}$. Данная наиболее обширная и наиболее современная западноевропейская кодификация частного права XX в. ${ }^{115}$ со-

109 J. Wegan [1958, p. 165] утверждает, что австрийская ипотека не зависит от определенного обязательства и является самостоятельной правовой конструкцией.

110 Определенное сходство можно найти в ситуации, когда австрийский Верховный Суд не признал ограничения, наложенные на обеспеченное ипотекой обязательство, размер которого не быц определен на момент установцения ипотеки. См.: [Pisuliński, J., 2002, p. 28 ff.].

111 Об акцессорности в немецком праве: [Medicus, D., 1971, p. 497 ff.].

112 Например, § 768 абз. 1 преди. 2; § 1137 абз. 1 предл. 2; § 1211 абз. 1 предл. 2 BGB; cp.: [Habersack, M., 1997, p. 860].

113 Описание истории развития немецких вещных способов обеспечения исполнения обязательств: [Jaschinska, M., 2004, p. 49 ff.].

114 Более подробно о гоммандской кодификации: [Nieper, F. and Ploeger, Н., 1999, p. 157 ff.; Remien, O., 1994, p. 187 ff.; Hartkamp, A., 1993, p. 664 ff.; Drobnig, U., 1993, p. $171 \mathrm{ff}$.$] .$

115 Кодификация дмимась более 40 мет; Кодекс вступим в силу 1 января 1992 г. 
держит исключительно акцессорное право залога ${ }^{116}$. Стоит подчеркнуть, что гомландский законодатель не решился ввести неакцессорные формы замогового права, хотя данная конструкция, несомненно, была ему известна.

\section{f) Право государств Центральной и Восточной Европь}

Большая часть государств Центральной и Восточной Европы при проведении основательной реформы своих правовых систем в поисках наиболее оптимальной формы защиты инвестиций основывались исключительно на вещных способах обеспечения акцессорного характера ${ }^{117}$. $\mathrm{K}$ таким государствам относится, например, Польша, где акцессорность является одним из основных свойств ипотеки ${ }^{118}$. Попытки введения неакцессорного права залога недвижимости, основанного на немецком поземельном долге, породими в Польше множественные споры и обоснованную критику в доктрине, поэтому до настоящего времени так и не были урегулированы в нормативном акте ${ }^{119}$.

\section{g) Распространение приниипа акиессорности}

Неакцессорное право залога недвижимости существует всего мишь в нескоцьких государствах Европейского союза [Pisuliński, J., 2005a, p. 842 ff.; Bieranowski, A., 2004, p. 87; Kircher, S., 2004, p. 394 ff.]. K ним относятся ${ }^{120}$

116 Ср. ст. 3:227-3:275 (общие положения 3:227-3:235; залог 3:236-3:259; ипотека 3:260-3:275) BW.

117 Болгария: ст. 149-155 (общие положения), ст. 156-161 (залог движимого имущества), ст. 162-165 (залог права требования), ст. 166-179 (ипотека) Закона об обязательствах и договорах от 1 января 1950 г. (Закон за задъмженията и договорите. Попр. ДВ. бр. 2 от 3 Януари 1950 г., обн. ДВ. бр. 275 от 22 Ноември 1950 г.); G. Ries в: Handbuch Wirtschaft und Recht in Osteuropa. München, 2007. T. 1, D. III, nb. 24; Чехия: § 152-174 Гражданского кодекса от 26 февраля 1964 г. (Občansky zakonik. 1964. Č. 40. Sb.); A. Schwarz, J. Adam B: Handbuch... T. 1, D. III, nb. 115; Словакия: § 151a-151mе Гражданского кодекса от 26 февраля 1964 г. (Občansky zakonik č. 40/1964 Zb.); I. Wemer, A. Wemer в: Handbuch... T. 4, D. III., nb. 36.

118 Статьи 73, 79, 94 3.к.к.и.; об акцессорности ипотеки в польском праве см.: [Pisuliński, J., 2005b, p. 554 ff.]; историческая справка о польской ипотеке: [Jaschinska, M., 2004, p. 53 ff.; Bardach, J., Leśniodorski, B. and Pietrzak, M., 1976, p. 149; Heropolitańska, I. and Michalski, M., 2001, p. 26 ff.; Rudnicki, S., 2006, p. 13 ff.].

119 По вопросу введения поземельного долга в Польше высказывались: J. Pisuliński [2005a, p. 837 ff.; 2001, p. 9 ff.], M. Jaschinska [2004, p. 57 ff., 166 ff.], A. Bieranowski [2004, p. 74 ff.], A. Dubicka [2004, p. 99 ff.], R. Sztyk [2003, p. 221 ff.; Pisuliński, J., 2001].

120 S. Kircher [2004, p. 395 ff.] также включает Швецию и Данию; иначе [Ріsuliński, J., 2005a, p. 844]; иначе, чем в шведском праве, также: [Westerman, D. and Hermann, R., 1999, p. 534 ff.]; об ипотеке в Дании: [Hitchcock, Т. С. and Paulsen, M. S., 1999, p. 55]. 
Германия ${ }^{121}$, Венгрия ${ }^{122}$, Эстония ${ }^{123}$ и С овения $^{124}$. В свою очередь, акцессорное вещное обеспечение известно всем европейским правовым системам $^{125}$. В такой ситуации не приходится говорить о всеобщей тенденции к замещению акцессорной ипотеки новыми, неакцессорными формами вещного обеспечения в государствах Европейского союза [Pisuliński, J., 2005a, p. 842 ff.; Bieranowski, A., 2004, p. 87; Pisuliński, J., 2001, p. 12; Wachter, T., 1999, p. 64]. Таким образом, евроипотека акцессорного характера могла бы основываться на известном и закрепившемся в Европе правовом принципе. Европейский законодатель при этом не был бы связан принятыми в конкретных кодификациях решениями, но мог бы в необходимой степени доработать данный принцип и привести его в соответствие с потребностями единого рынка [Wachter, T., 1999, p. 60].

\section{С) Принцип гибкой акцессорности}

Сторонники акцессорной евроипотеки подчеркивают, что речь идет не об установлении акцессорности в качестве безусловно обязательной догмы права, а о гибком ее формировании с учетом целей, которым она будет служить. В частности, речь идет об ослаблении связи между вещным обеспечением и обеспеченным обязательством путем введения исключений из правила акцессорности. Впрочем, такие исключения, хоть и в различной мере, известны внутригосударственным кодификациям. Смягчению акцессорности способствует, к примеру, ипотека, обеспечивающая обязательство, размер которого не был определен на момент установцения ипотеки, которая может быть использована для обеспечения обязательств, размер которых еще неизвестен, будущих и условных обязательств ${ }^{126}$. В законодательстве европейских стран встречаются также и иные институты, которые служат смягчению акцессорности, например распоряжение освободившимся ипотечным местом ${ }^{127}$, ипотека соб-

\section{$121 \S 1191-1198$ BGB.}

$122 \S 269$ венгерского Гражданского кодекса (1959. évi IV. törvény a Polgári Törvénykönyvrol - Закон № IV 1959 г. о Гражданском кодексе); положение, введенное Законом № XXVI 1996 г. об изменении некоторых поможений гражданского кодекса Венгерской Республики (1996. évi XXVI. törvény a Magyar Köztársaság Polgári Törvénykönyve egyes rendelkezéseinek módositásáról), вступило в силу 1 мая 1996 г.

123 § 325 эстонского Закона о вещном праве от 9 июня 1993 г. (Ringi Teataja. 1993. Nr. 39. Poz. 590 (с изм.), вступившего в силу 1 декабря 1993 г.

124 § 192-200 словенского Кодекса вещного права от 27 декабря 2002 г. (Stvarnopravni zakonik. 2002. Št. 87. S. 9559), вступившего в силу 1 января 2003 г.

125 Об акцессорности в немецком, французском, итальянском, гоммандском, английском праве см.: [Habersack, М., 1997, p. 861].

126 Ср. ст. 102-108 З.к.к.и.; § 1113 п. 2, § 1190 BGB, § 14 п. 2 GBG.

${ }^{127}$ Cp. § 58 GBG; о проекте введения данного правового института в польское право см.: [Swaczyna, B., 2003, p. $211 \mathrm{ff}$.]. 
ственника ${ }^{128}$, ипотека в форме письма ${ }^{129}$, администратор ипотеки ${ }^{130}$, а также ипотека на ранее установленной ипотеке (subintabulat) ${ }^{131}$. Используя представленные конструкции, можно бымо бы на европейском уровне осуществить их модификацию и привести к единообразию.

"Европеизация" акцессорности предоставима бы возможность дия дамьнейшего ее развития в направлении большей защиты правового оборота и адаптации данного принципа к экономическим потребностям, не создавая при этом угрозы дия интересов ипотечного домжника [Wachter, T., 1999, p. 60]. Развивая, например, конструкцию ипотеки, обеспечивающей обязательство, размер которого не быц определен на момент установцения ипотеки, предлагается сформировать евроипотеку таким образом, чтобы она обеспечивала все (существующие и будущие) требования кредитора в

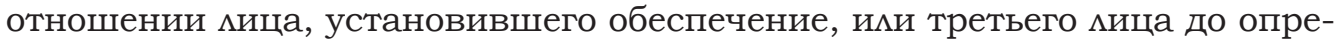
деменной максимальной суммы без необходимости указания на основание возникновения долга. Евроипотека, обеспечивающая обязательство, размер которого не бым определен на момент установления ипотеки, могла бы использоваться дмя обеспечения нескомьких требований, которые принадлежат одному и тому же кредитору. Поскольку такая ипотека служила бы обеспечению требования, размер которого не определен, принудительное исполнение согласно нотариальному документу домжно быть допустимо искАючительно в отношении существующей и определенной части неудовцетворенного права требования. Несмотря на то что такая ипотека служила бы обеспечению будущих обязательств, принимая во внимание очередность внесения записи в кадастровую книгу, она была бы действительной с момента ее установцения. С гибкостью евроипотеки, обеспечивающей обязательство, размер которого не был определен на момент установления ипотеки, во внутренних отношениях, были бы связаны опредеменные ограничения во внешних отношениях. Поскольку запись о такой ипотеке не содержит сведений о размере требования, доказывание его размера возмагалось бы на ипотечного кредитора. Это позволило бы избежать случаев зиоупотребления правом [Wachter, T., 1999, p. 61].

128 Cp. § 1163 п. 1, § 1168, § 1177 BGB; [Eickmann, D., 1997, § 1163, p. 1794 ff., $\S 1177$, p. 1852 ff.]; похожие, хоть и не идентичные конструкции известны австрийскому праву, ср. § 469 абз. 470 предл. 2, § 1446 ABGB; § 53 GBG; [Koziol, Н. and Welser, R., 2000, p. 353 ff.; Koch, B., 2007, § 469, p. 455 ff.]; J. Wegan [1958, p. 161] не считает немецкую ипотеку собственника искцючением из правила акцессорности, поскоцьку, по его мнению, ипотека собственника не явцяется за-

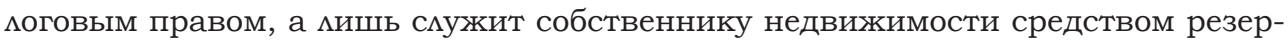
вации места дия будушего залогового права.

129 § 1116-1117, 1160 BGB; [Eickmann, D., 1997, § 1116, p. 1608 ff.].

130 Можно было бы использовать регулирование, схожее с регулированием администратора зарегистрированного залога; см. ст. 4 п. 1 Закона от 6 декабря 1996 г. о регистрируемом залоге и залоговом реестре (Dz.U. Nr. 149. Poz. 703 (с изм.).

131 Ср. ст. 65 абз. 4, п. 4, ст. 1081-1085 З.к.к.и. 


\section{D) Защита ипотечного должника}

Если принять во внимание тот факт, что среди заемщиков существенную часть составляют потребители, а следовательно, мица, находящиеся согласно законодательству Европейского союза под особой защитой, то защитная функция акцессорности приобретает особое значение. Нельзя также забывать о том, что принцип акцессорности не функционирует в правовой системе самостоятельно, но в связи с иными принципами и вместе с ними создает единое целое; она служит прежде всего защите собственника обремененной недвижимости от змоупотребцений со стороны кредитора. Акцессорный характер евроипотеки, таким образом, быц бы следствием ее обеспечительного характера. Отказ от нее, в свою очередь, влечет возникновение пробцемы защиты интересов ипотечного должника, а в более широком контексте может привести к нарушению функционирования правовой системы.

Недостаточная защита, в частности риск двойной опматы, явцяется одной из причин нечастого применения неакцессорного права залога недвижимости в Венгрии. В случае отчуждения самого права залога мицо, которое предоставило обеспечение, теряет возможность ссылаться на договор обеспечения, на основании которого данное право возникло. Венгерское право не предусматривает возможности внесения возражений, основанных на договоре обеспечения, в кадастровую книгу ${ }^{132}$. Из этого следует, что мицо, устанавливающее обеспечение, не может выдвинуть возражение о том, что оно уже удовцетворило требование, и будет вынуждено запцатить повторно. Еще не сформировалась венгерская судебная практика, указывающая, какие требования и против кого в данном случае могут быть предъявцены. Из этого следует, что мицо, устанавливающее обеспечение, не может выдвинуть возражение о том, что оно уже удовцетворицо требование, и будет вынуждено запцатить повторно. Еще не сформировалась венгерская судебная практика, указывающая, какие требования и против кого в данном случае могут быть предъявлены. В знано достаточным дмя защиты интересов собственника обремененной недвижимости. В этой связи в Венгрии более охотно используется традиционная ипотека, а неакцессорное право залога используется только ипотечными банками, т. е. в относительно узком секторе рынка кредитов ${ }^{133}$.

132 См. § 16-17 венгерского Закона о кадастровых книгах от 17 декабря 1997 г. (1997. évi CXLI. törvény az ingatlan-nyilvántartásról).

133 Банк, предоставцяя клиенту кредит, обеспечивает свое требование при помощи неакцессорного права залога недвижимости, которое впоследствии (без обеспеченного обязательства) переносит на ипотечный банк. На этой основе ипотечный банк эмитирует ипотечные облигации. Банк, который предоставиц кредит, а впоследствии произвец отчуждение его обеспечения, обязан выкупить его по частям. В случае неисполнения данной обязанности ипотечный банк приобретает обеспеченное неакцессорным правом залога требование и как цессионарий 
Если принять это во внимание, не вызывает удивцения тот факт, что подготовценный недавно под руководством профессора $\Lambda$ асло Векаса проект новой кодификации венгерского гражданского права ${ }^{134}$ не содержит положений о неакцессорном праве залога недвижимости. В обосновании проекта в качестве причины такого решения указывается недостаточная защита ипотечного домжника ${ }^{135}$.

Е) Европейская модель нового обеспечения

В каждом государстве - участнике ЕС существуют специфические проблемы правового и экономического характера, которые, однако, имеют искцючительно мокальное значение и явцяются следствием скорее не препятствий системного характера, но принятой банковской практики предоставления кредитов, в частности схем финансирования инвестиций ${ }^{136}$. При формировании структуры евроипотеки необходимо руководствоваться прежде всего общеевропейскими категориями. Реализация попытки учесть все, зачастую очень разцичные, потребности мокальных рынков представцяется мало возможной. Впрочем, это не должно становиться целью евроипотеки; напротив, она должна стать импульсом дмя положительных изменений на этих рынках, создать новые возможности финансирования инвестиций, способствовать интеграции европейского рынка ипотечных кредитов и его динамичному развитию, повысить его эффективность, увеличить ассортимент продуктов и тем самым конкуренцию, а в результате снизить стоимость кредитов.

Принимая во внимание сложность рассматриваемого вопроса и его тесную связь с иными отраслями права, а также распространение принципа акцессорности и его утверждение в европейской правовой традиции, необходимо признать, что процесс интеграции акцессорной ипотеки

информирует об этом домжника. В таком случае должнику не грозит двойная оплата, поскольку его кредитор - независимо от того, явцяется ми им банк, который предоставил кредит, или ипотечный банк, - обладает как правом требования, так и обеспечивающим его правом залога. При этом необходимо подчеркнуть, что такое решение явцяется следствием не конструкции неакцессорного права залога, а регулирования, содержащегося в венгерском Законе об ипотечных банках и ипотечных облигациях; см. § 8 п. 6 Закона об ипотечных банках и ипотечных облигациях от 8 мая 1997 г. (1997. évi XXX. törvény a jelzáloghitelintézetről és a jelzáloglevélről).

134 Проект кодификации, содержащий в том числе положения, касающиеся вещного права, вместе с обоснованием доступен на сайте венгерского Министерства юстиции по адресу: http: / /irm.gov.hu/?mi=1\&katid=193\&id=217\&cikkid=3316

135 Проект новой венгерской кодификации, вещное право, с. 139 и далее; http:// irm.gov.hu/download/negyedikdologijog.pdf/negyedikdologijog.pdf

136 Например, в Германии при ипотечном обеспечении инвестиций имеются проблемы с поэтапным финансированием (Abschnittsfinanzierung), финансированием через посредников (Zwischenfinanzierung). См.: [Wachter, Т., 1999, p. 62 ff.; Stöcker, O., 1992, p. 44 ff., 58 ff.]. 
бым бы, несомненно, более простым, чем введение нового института неакцессорного характера, неизвестного подавцяющему большинству европейских государств [Wachter, T., 1999, p. 63].

\section{3. На распутъе между акиессорностью и неакиессорностью}

В поисках новых возможностей найти компромисс между представценными выше конструкциями евроипотеки в немецкой $и$ тературе выдвинута концепция, называемая differenzierte Nicht-Akzessorietät [Köndgen, J. and Stöcker, O., 2005, p. 117 ff.]. Данная концепция отходит от неакцессорности в ее крайней форме и гласит, что неакцессорная конструкция евроипотеки не явцяется бесспорной юридической догмой и самоцемью;

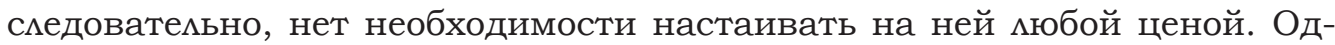
нако важным явцяется предоставцение возможности гибкого применения евроипотеки при одновременном обеспечении необходимой защиты собственника недвижимости. Неакцессорность следует рассматривать не как противоположность акцессорности, а как техническое упрощение дия новых финансовых схем, которое позволит осуществить замену права требования и отделить право залога от обеспеченного им обязательства. В качестве одной из возможных модификаций неакцессорности предмагается, например, ввести допустимость выдвижения возражений, ко-

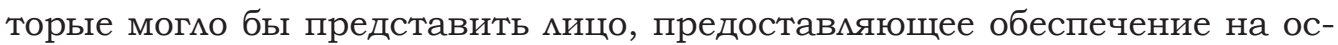
новании договора обеспечения, также против очередного мица, которое приобрело евроипотеку. Дия достижения такого результата предлагается несколько решений [Köndgen, J. and Stöcker, O., 2005, p. 119]:

а) характер евроипотеки как права, служащего обеспечению исполнения обязатемьств, мог бы рассматриваться как производный от типа обеспечения;

b) характер ипотеки как средства обеспечения мог бы указываться в кадастровой книге ${ }^{137}$;

c) договор обеспечения мог бы иметь вещно-правовые последствия ${ }^{138}$;

d) содержащееся в договоре обеспечения требование о перенесении

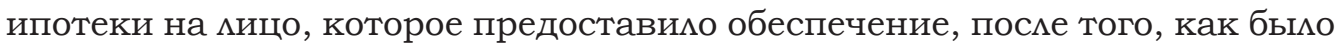
исполнено предназначение обеспечения, могмо бы быть гарантировано законодательно предусмотренной записью в кадастровой книге ${ }^{139}$. Таким образом, требование, которое может быть реализовано при участии только миц, явцяющихся сторонами договора, обрело бы вещный характер;

137 Это противоречимо бы существующей в немецком праве доктрине [Köndgen, J. and Stöcker, O., 2005, p. 119].

138 Авторы, однако, признают, что в результате это привело бы к трансформации евроипотеки в полностью акцессорную ипотеку [Köndgen, J. and Stöcker, O., 2005, p. 119].

139 Предлагается сделать допустимой запись по образцу § 1179а п. 1 предл. 3 BGB [Köndgen, J. and Stöcker, O., 2005, p. 119].

Правосудие/Justice. Т. 3, № 1. 2021. Переводы 
это дало бы возможность ссылаться на него также в случае отчуждения евроипотеки третьему мицу.

С высоким уровнем доверия к содержанию кадастровой книги, основанным в том числе на принципе достоверности кадастровых книг, свя-

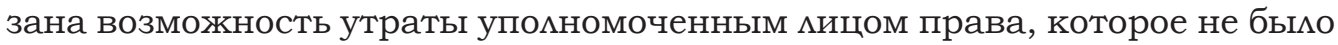
записано в кадастровой книге. Это связано с необходимостью обеспечения безопасности правового оборота. Таким образом, законодатемь санкционирует преимущество защиты интересов покупателя, действующего добросовестно, перед защитой фактически уполномоченных $\Lambda и ц{ }^{140}$.

В этой связи рассматривается предложение ограничить использование евроипотеки и предоставить возможность ее использования исключительно учреждениям, находящимся под государственным контролем. В данном случае речь идет не о введении специальных норм, регулирующих принцип достоверности кадастровых книг, поскольку в Европе данный принцип урегулирован по-разному, но об общем правиле, согласно которому евроипотека может быть установцена только в пользу кредитора, находящегося под государственным контролем. В данном контексте кАючевым моментом считается поиск ответов на следующие вопросы [Köndgen, J. and Stöcker, O., 2005, p. 120]:

а) наскоцько эффективно удастся избежать двойного (повторного) исполнения обязательства, т. е. исполнения обязательства за счет обремененной ипотекой недвижимости, в случае, если обеспеченное ипотекой требование перестало существовать ими бымо удовлетворено?

b) насколько высоким домжен быть уровень защиты домжника от двойного исполнения обязательства?

с) какие правовые механизмы необходимо ввести, чтобы исключить двойное исполнение обязательства?

d) в какой мере принцип гарантии достоверности кадастровых книг домжен применяться в отношении содержания и объема евроипотеки?

е) домжны $\Lambda$ данные вопросы быть урегулированы однообразно во всем Европейском союзе, или их регулирование следует предоставить законодателю государства?

Кроме необходимости защитить интересы собственника недвижимости возникает существенный с экономической точки зрения вопрос о необходимом уровне свободы оборота евроипотеки. Чем выше данный уро-

140 J. Köndgen и O. Stöcker [2005, p. 120] в данном контексте подчеркивают, что риск двойной опматы, которому подвержено мицо, предоставцяющее обеспечение, не является следствием неакцессорного характера залогового права, а связан с принципом достоверности кадастровых книг, который при добросовестном приобретении права, записанного в кадастровой книге, влечет за собой утрату права выдвигать против покупателя (цессионария) возражения, основанные на договоре, устанавцивающем цель обеспечения. Однако это не явцяется уникальной чертой немецкого поземельного доцга и касается также акцессорной ипотеки (§ 1138 BGB); также [Kircher, S., 2004, p. 391].

Pravosudie/Justice. Vol. 3, no. 1. 2021. Translations 
вень, тем большей должна быть гибкость связанных с залоговым правом финансовых инструментов и инструментов рефинансирования. В свою очередь, чем больше обязанностей по информированию ${ }^{141}$ будет возможено на кредитора, тем выше будут административные расходы, которые в итоге покрывает домжник.

Важной цемью дальнейших работ над евроипотекой считается поиск разцичных элементов акцессорности и опредемение дмя каждого из них уровня акцессорности, который с юридико-политической точки зрения следует признать необходимым, а следовательно, - если смотреть с другой стороны - насколько приемлемой была бы неакцессорность евроипотеки с учетом ее гибкости и свободы оборота и при условии защиты собственника обремененной недвижимости. Золотая середина в данном случае видится в формировании евроипотеки как вида неакцессорного залогового права, которое допускает ее точечную связь с правом требования.

\section{V. Выводы}

Проблематику евроипотеки нельзя рассматривать исключительно с теоретической точки зрения. Евроипотека домжна быть не самоцелью, но инструментом, который помогает достичь цели, которой является дальнейшая интеграция европейского кредитного рынка с учетом интересов всех граждан Европейского союза. Такая цель присуща всем представленным ранее концепциям, а различия между гибкой акцессорностью и умеренной неакцессорностью с практической точки зрения не явцяются существенными.

С одной стороны, на начальном этапе гармонизации не следует настойчиво внедрять абсолютно чуждые большинству правовых систем стран ЕС решения. Достаточно сложной задачей является создание современного европейского способа обеспечения исполнения обязатецьств на основе исторически общих элементов. Поэтому при поисках общего знаменателя не следует a priori считать принцип акцессорности причиной всех пробцем и относиться к нему как к историческому факту, который явцяется $\Lambda$ иним в современной правовой системе. Следует принимать во внимание, что подробный анализ институтов, способствующих увемичению гибкости евроипотеки, может привести к выводу, что они еще не полностью использовали свой потенциал и могут быть модифицированы и интегрированы на европейском уровне. Подтвердить это может уверенность в том, что евроипотека, основанная на принципе гибкой акцессорности, смогла бы удовцетворить требования правового оборота. В пользу такого решения свидетемьствует также простота интеграции данной конструкции в области права, что в настоящее время относится к компетенции законодателя государства. Дополнитемьно также можно указать на очень осторожный подход к евроипотеке, что подтверждается результата-

141 Предназначением которых могмо бы быть исключение возможности добросовестного приобретения права. 
ми анализа Зеленой Книги, проведенного недавно Европейской Комиссией. На государственном уровне достаточно проанализировать опыт Венгрии и критические замечания к проекту по введению в польское право неакцессорного поземемьного долга по немецкому образцу [Pisuliński, J., $2005 a$, p. 846 ff.]. Сходная ситуация будет иметь место в остальных государствах, находящихся под вциянием французской правовой традиции, в которой в качестве формы права залога на недвижимости выступает только акцессорная ипотека ${ }^{142}$.

С другой стороны, право должно идти навстречу экономическим потребностям и создавать инструменты, которые упростят регулирование общественных отношений в условиях изменяющейся действитецьности. Не существует непреодолимых препятствий дмя введения конструкции неакцессорной ипотеки в польскую правовую систему. Неакцессорный характер евроипотеки, однако, может - в частности, на начальном этапе применения - порождать многочисленные сомнения и будет требовать разъяснений. Это подтверждается опытом Германии, где поземемьный долг в течение многих мет завоевывал свое место на рынке, а его успех основан на многолетней практике, богатых теоретических исследованиях и сформировавшейся судебной практике. В данном контексте знаменательным явцяется тот факт, что несомненное большинство мнений относительно Зеленой Книги, в том числе 100\% потребителей, не создало однозначную позицию по отношению к евроипотеке. Эта осторожная нерешительность, даже, можно сказать, отрицательная позиция может быть во многих случаях следствием отсутствия достаточных знаний по данной проблематике и непонимания сущности нового права. На это указывает в том числе позиция немецкого Бундесрата ${ }^{143}$. Если, наконец, законо-

142 [Hofmeister, H., 1991, p. 28], хотя автор утверждает, что неакцессорная конструкция евроипотеки заслуживает особого внимания, он все же признает, что австрийское право не знает конструкции "абстрактных вещных прав", и поэтому такая форма залогового права воспринимается скептически. В связи с этим также приедмагается - вместо "абстрактного" права залога недвижимости - рассмотреть вариант евроипотеки с существенно ограниченной акцессорностью и усиленной защитой цессионария в отношении размера права требования и соединить такую форму (в отмичие от австрийской закладной ипотеки) с принципом немедменного приведения в исполнение.

143 "...Введение дополнительного, неакцессорного права залога недвижимости в настоящее время не является необходимым. В немецком правовом обороте более 100 мет существует акцессорная ипотека и неакцессорный поземемьный долг. На практике при предоставлении кредитов предпринимателями предпринимателям или потребителям поземельный долг применяется более чем в 99\% случаев. Существенные недостатки данного правового положения для потребителей в действительности явцяются незаметными. Возможность выбора между акцессорным и неакцессорным способом обеспечения представляется обоснованной и практичной. Возможности немецкого права являются достаточными также дмя удовлетворения требований международного правового оборота. Следова- 
дательно ограничить применение неакцессорной ипотеки искцючительно до кредитов, предоставцяемых организациями, находящимися под контролем государства, то на практике это искцючит возможность зцоупотреблений. В такой ситуации проблема двойного исполнения обязательства или проблема нарушения прав потребителя будет минимизирована и наверняка не будет более серьезной, чем при использовании традиционных средств обеспечения. При таком институциональном ограничении не возникает препятствий дмя введения неакцессорной ипотеки наряду с существующими внутригосударственными средствами обеспечения. Следует признать целесообразным законодательное урегулирование обеспечитемьного договора как суррогата акцессорности, в частности определения его essentialia negotii и установления дия него нотариальной формы.

Гибкая акцессорность и умеренная неакцессорность - это два варианта, которые при соответствующем урегулировании могут привести к аналогичному результату. На современном этапе интеграции, однако, эти пути отмичаются по своей сложности. В конце концов необходимо согласиться с точкой зрения, согласно которой успех евроипотеки будет зависеть в меньшей степени от преодоления технических и правовых проблем, а в большей - от экономической выгоды [Wehrens, H., 1992, p. 560].

Подведем итог вышизцоженному: идея евроипотеки заслуживает поддержки. Однако создание евроипотеки, которая с момента возникновения и до момента прекращения была бы аналогично урегулирована во всех государствах ЕС, на данном этапе гармонизации гражданского права следует признать невозможным ${ }^{144}$. При этом евроипотека могла бы, несомненно,

тельно, введение очередного, неакцессорного права залога недвижимости законодателем ЕС в настоящее время не является целесообразным..." (Bundesrat, Drucksache 744/05 (Beschluss vom 25. November 2005), s. 10).

144 Это ни в коей мере не изменяет основного значения проблематики интеграции евроипотеки во внутригосударственное право. Чтобы обеспечить кредитору, требование которого обеспечено евроипотекой, реальную аналогичную возможность удовцетворить свое требование, следовало бы, в частности, провести работы по сближению положений, регулирующих взыскание с недвижимости, и разработать, как минимум, одинаковые минимальные стандарты во всех европейских государствах. В первую очередь следовало бы рассмотреть возможность ограничения и приведения к единообразию правим исполнительного производства и обеспечить таким образом одинаковую очередность удовлетворения требований ипотечного кредитора во всех государствах ЕС. В противном случае кредитор, использующий новый способ обеспечения, был бы связан иными методами проведения взыскания в государстве, на территории которого расположена обремененная ипотекой недвижимость. В результате польская, немецкая, французская или английская евроипотека были бы размичными по эффективности обеспечения. При этом речь не идет о создании особых наднациональных правиц удовлетворения требований, основанных на евроипотеке, и, следовательно, обеспечении ее преимущественной позиции по отношению к иным формам обеспечения; напротив, евроипотека должна иметь возможность конку- 
дать импульс для дамьнейшей гармонизации гражданского права. Немьзя игнорировать факт, что гармонизация права явцяется искусством поиска компромисса, требует способности объединять часто существенно отмичающиеся интересы и решения, возникшие в рамках различных правовых традиций и основанные на противоположных принципах. Поэтому при проведении дальнейших работ существенным будет объединение сил всех исследовательских групп, которые занимаются проблематикой евроипотеки, и разъяснение основных принципов и целей нового института объединениям, которые призваны высказаться по данному вопросу.

\section{Список испомьзованной мнтературы}

Bardach J., Leśniodorski B., Pietrzak M. Historia państwa i prawa polskiego. Warszawa, 1976.

Becker-Eberhard E. Die Forderungsgebundenheit der Sicherungsrechte. Bielefeld, 1993.

Beysen E. Sachenrecht in Europa / ed. Ch. v. Bar. Osnabrüc, 2001. Bd. 4.

Bieranowski A. Dług gruntowy (uwagi na tle projektowanej regulacji) / / Rejent. 2004. Nr. 10.

Drobnig U. Das neue niederländische bürgerliche Gesetzbuch aus vergleichender und deutscher Sicht / / European Review of Private Law. 1993.

Dubicka A. Dług gruntowy - nowe ograniczone prawo rzeczowe // Rejent. 2004. Nr. 10.

Eickmann D. // Münchener Kommentar zum BGB. T. 6. München, 1997.

Ferid M. Das französische Zivilrecht. Frankfurt a. M.: Berlin, 1971. T. 2. Habersack M. Die Akzessorietät - Strukturprinzip der europäischen Zivilrechte und eines künftigen europäischen Grundpfandrechts // Juristen Zeitung. 1997. No. 18.

Hartkamp A. Das neue niederländische Bürgerliche Gesetzbuch aus europäischer Sicht // Rabels Zeitschrift. 1993. No. 57.

Heropolitańska I., Michalski M. Hipoteka, listy zastawne, obligacje hipoteczne. Warszawa, 2001.

Hofmeister H. Das liegenschaftsrecht im Zeichen der Annährung Österreichs an die EG // ÖNZ. 1991.

рировать с уже существующими внутригосударственными средствами обеспечения на равных на основе принципов, которые должны, по мере возможности, быть одинаковыми во всем Европейском союзе. 
Jaschinska M. Polnische und deutsche Grundpfandrechte im Vergleich. Berlin, 2004.

Kaindl R. Die eurohypothek // Österreichische Notariatszeitung. 1993. No. 12 .

Kiesgen Ch. Ein Binnenmarkt für den Hypothekarkredit. Köln, 2004.

Kircher S. Grundpfandrechte in Europa. Überlegungen zur Harmonisierung der Grundpfandrechte unter besonderer Beachtung der deutschen, französischen und englischen Rechtsordnung. Berlin, 2004.

Klein Ch., Tietz S. Frankreich reformiert sein Kreditsicherungsrecht / / Recht der Internationalen Wirtschaft. 2007.

Koch B. // ABGB Kommentar / ed. H. Koziol, P. Bydliński, R. Bollenberger. Wiedeń, 2007.

Köndgen J., Stöcker O. Die Eurohypothek - akzessorietät als Gretchenfrage? / / Zeitschrift für Bankrecht und Bankwirtschaft. 2005. No. 2.

Kostecki S. Kilka uwag na temat długu gruntowego w prawie niemieckim // Rejent. 2006. Nr. 9.

Koziol H., Welser R. Bürgerliches recht. Bd. 1. Wiedeń, 2000.

Leutner G., Lehberg T. Die Entdeckung der Grundschuld: Die "wiederauffüllbare Hypothek" (hypothèque rechargeable) als neues Kreditsicherungsmittel im französischen Recht // Zeitschrift für Immobilienrecht. 2006. No. 22.

Luckow A. // Basic Guidelines for a Eurohypothec. Outcome of the Eurohypothec workshop, November 2004 / April 2005 / ed. A. DrewiczTułodziecka // Mortage Bulletin. 2005. No. 21. C-1.

Medicus D. Durchblick: Die Akzessorietät im Zivilrecht // Juristische Schulung. 1971.

Nieper F., Ploeger H. Sachenrecht in Europa / ed. Ch. v. Bar. Bd. 3. Osnabrück, 1999.

Petrasch F. Kommentar zum ABGB / ed. P. Rummel. Wien, 1983.

Pisuliński J. Hipoteka kaucyjna. Kraków, 2002.

Pisuliński J. O długu na nieruchomości // Transformacje Prawa Prywatnego. 2001. Nr. 1.

Pisuliński J. O planowanej nowelizacji ustawy o ksiegach wieczystych i hipotece i wprowadzeniu długu gruntowego // KPP. 2005a. R. XIV, Nr. 3.

Pisuliński J. System prawa prywatnego. T. 4: Prawo rzeczowe. Warszawa, 2005b. 
Remien O. Das neue Burgerlijk Wetboek der Niederlande und seine Erschließung durch die Rechtsliteratur // Zeitschrift für europäisches Privatrecht. 1994.

Rudnicki S. Hipoteka jako zabezpieczenie wierzytelności. Warszawa, 2006.

Rudnicki S. Komentarz do ustawy o ksiegach wieczystych i hipotece. Warszawa, 2002.

Stöcker O. Die "Eurohypothek" - Wegbereiter zu einem Binnenmarkt für den Hypothekarkredit / / Zeitschrift für Finanzierung, Kapitalanlage und Immobilienwesen - Der Langfristige Kredit. 1991. No. 16/17.

Stöcker O. Die "Eurohypothek", zur Bedeutung eines einheitlichen nicht-akzessorischen Grundpfandrechts für den Aufbau eines "Europäischen Binnenmarktes für den Hypothekarkredit" mit einer Darstellung der Verwendung der Grundschuld durch die deutsche Hypothekarkreditpraxis sowie des französischen, spanischen und schweizerischen Hypothekenrechts. Berlin, 1992.

Stöcker O. Die Eurohypothek - ein Sicherungsinstrument der Zukunft // Immobilien Manager. 2006. No. 6.

Stürner R. Das Grundpfandrecht zwischen Akzessorietät und Abstraktheit und die europäische Zukunft / / Festschrift für Rolf Serick zum 70. Geburtstag / ed. U. Huber, E. Jayme. Heidelberg, 1992.

Swaczyna B. Rozporządzanie opróżnionym miejscem hipotecznym i hipoteka właściciela (Uwagi na tle projektu Komisji Kodyfikacyjnej Prawa Cywilnego) // KPP 2003. R. XII, Nr. 1.

Sztyk R. Dług gruntowy w praktyce notarialnej // Rejent. 2003. Nr. 12. Wachter T. Die Eurohypothek - grenzüberschreitende Kreditsicherung an Grundstücken im Europäischen Binnenmarkt // WM. 1999. No. 2.

Wegan J. Die Hypothek als akzessorisches Recht / / Festschrift artur Steinwenter zum 70. geburtstag. Graz ; Köln, 1958.

Wehrens H. Überlegungen zu einer eurohypothek // Wertpapier Mitteilungen - Zeitschrift für Wirtschafts- und Bankrecht. 1992. No. 14.

Westerman D., Hermann R. Sachenrecht in Europa / ed. Ch. v. Bar. Bd. 1. Osnabrück, 1999.

Wieling H. Sachenrecht. Trier, 2001.

Wolfsteiner H., Stöcker O. Nicht-akzessorisches Grundpfand für Mitteleuropa // ZBB. 1998. No. 4.

Wołodkiewicz W., Zabłocka M. Prawo rzymskie, instytucje. Warszawa, 2005. 


\section{References}

Bardach, J., Leśniodorski, B. and Pietrzak, M., 1976. Historia państwa i prawa polskiego. Warszawa.

Becker-Eberhard, E., 1993. Die Forderungsgebundenheit der Sicherungsrechte. Bielefeld.

Beysen E., 2001. Sachenrecht in Europa. Ed. Ch. v. Bar. Osnabrück. Bd. 4.

Bieranowski, A., 2004. Dług gruntowy (uwagi na tle projektowanej regulacji). Rejent, 10.

Drobnig, U., 1993. Das neue niederländische bürgerliche Gesetzbuch aus vergleichender und deutscher Sicht. European Review of Private Law.

Dubicka, A., 2004. Dług gruntowy - nowe ograniczone prawo rzeczowe. Rejent, 10.

Eickmann, D., 1997. In: Münchener Kommentar zum BGB, Bd. 6. München.

Ferid, M., 1971. Das französische Zivilrecht. Bd. 2. Frankfurt am Main; Berlin.

Habersack, M., 1997. Die Akzessorietät - Strukturprinzip der europäischen Zivilrechte und eines künftigen europäischen Grundpfandrechts. Juristen Zeitung, 18.

Hartkamp, A., 1993. Das neue niederländische Bürgerliche Gesetzbuch aus europäischer Sicht. Rabels Zeitschrift, 57.

Heropolitańska, I. and Michalski, M., 2001. Hipoteka, listy zastawne, obligacje hipoteczne. Warszawa.

Hofmeister, H., 1991. Das liegenschaftsrecht im Zeichen der Annährung Österreichs an die EG. ÖNZ.

Jaschinska, M., 2004. Polnische und deutsche Grundpfandrechte im Vergleich. Berlin.

Kaind1, R., 1993. Die eurohypothek. Österreichische Notariatszeitung, 12.

Kiesgen, Ch., 2004. Ein Binnenmarkt für den Hypothekarkredit. Köln.

Kircher, S., 2004. Grundpfandrechte in Europa. Überlegungen zur Harmonisierung der Grundpfandrechte unter besonderer Beachtung der deutschen, französischen und englischen Rechtsordnung. Berlin.

Klein, Ch. and Tietz, S., 2007. Frankreich reformiert sein Kreditsicherungsrecht. Recht der Internationalen Wirtschaft.

Koch, B., 2007. In: ABGB Kommentar. Ed. H. Koziol, P. Bydliński, R. Bollenberger. Wiedeń. 
Köndgen, J. and Stöcker, O., 2005. Die Eurohypothek - akzessorietät als Gretchenfrage? Zeitschrift für Bankrecht und Bankwirtschaft, 2.

Kostecki, S., 2006. Kilka uwag na temat długu gruntowego w prawie niemieckim. Rejent, 9.

Koziol, H. and Welser, R., 2000. Bürgerliches recht. Bd. 1. Wiedeń.

Leutner, G. and Lehberg, T., 2006. Die Entdeckung der Grundschuld: Die "wiederauffüllbare Hypothek" (hypothèque rechargeable) als neues Kreditsicherungsmittel im französischen Recht. Zeitschrift für Immobilienrecht, 22.

Luckow, A., 2005. In: Drewicz-Tułodziecka, A., ed. Basic Guidelines for a Eurohypothec. Outcome of the Eurohypothec workshop, November 2004 / April 2005. Mortgage Bulletin, 21. C-1.

Medicus, D., 1971. Durchblick: Die Akzessorietät im Zivilrecht. Juristische Schulung.

Nieper, F. and Ploeger, H., 1999. Sachenrecht in Europa. Ed. Ch. v. Bar. Bd. 3. Osnabrück.

Petrasch, F., 1983. Kommentar zum ABGB. Ed. P. Rummel. Wien.

Pisuliński, J., 2001. O długu na nieruchomości. Transformacje Prawa Prywatnego, 1.

Pisuliński, J., 2002. Hipoteka kaucyjna. Kraków.

Pisuliński, J., 2005. O planowanej nowelizacji ustawy o księgach wieczystych i hipotece i wprowadzeniu długu gruntowego. $K P P, \mathrm{XIV}(3)$.

Pisuliński, J., 2005. System prawa prywatnego. T. 4: Prawo rzeczowe. Warszawa.

Remien, O., 1994. Das neue Burgerlijk Wetboek der Niederlande und seine Erschließung durch die Rechtsliteratur. Zeitschrift für europäisches Privatrecht.

Rudnicki, S., 2002. Komentarz do ustawy o ksiegach wieczystych $i$ hipotece. Warszawa.

Rudnicki, S., 2006. Hipoteka jako zabezpieczenie wierzytelności. Warszawa.

Stöcker, O., 1991. Die "Eurohypothek" - Wegbereiter zu einem Binnenmarkt für den Hypothekarkredit. Zeitschrift für Finanzierung, Kapitalanlage und Immobilienwesen - Der Langfristige Kredit, 16/17.

Stöcker, O., 1992. Die "Eurohypothek", zur Bedeutung eines einheitlichen nicht-akzessorischen Grundpfandrechts für den Aufbau eines "Europäischen Binnenmarktes für den Hypothekarkredit" mit einer Darstellung der Verwendung der Grundschuld durch die deutsche Hypothekarkreditpraxis sowie des französischen, spanischen und schweizerischen Hypothekenrechts. Berlin. 
Stöcker, O., 2006. Die Eurohypothek - ein Sicherungsinstrument der Zukunft. Immobilien Manager, 6.

Stürner, R., 1992. Das Grundpfandrecht zwischen Akzessorietät und Abstraktheit und die europäische Zukunft. In: U. Huber and E. Jayme, eds. Festschrift für Rolf Serick zum 70. Geburtstag. Heidelberg.

Swaczyna, B., 2003. Rozporządzanie opróżnionym miejscem hipotecznym i hipoteka właściciela (Uwagi na tle projektu Komisji Kodyfikacyjnej Prawa Cywilnego). KPP, XII(1).

Sztyk, R., 2003. Dług gruntowy w praktyce notarialnej. Rejent, 12.

Wachter, T., 1999. Die Eurohypothek - grenzüberschreitende Kreditsicherung an Grundstücken im Europäischen Binnenmarkt. WM, 2 .

Wegan, J., 1958. Die Hypothek als akzessorisches Recht. In: Festschrift artur Steinwenter zum 70. geburtstag. Graz; Köln.

Wehrens, H., 1992. Überlegungen zu einer eurohypothek. Wertpapier Mitteilungen - Zeitschrift für Wirtschafts- und Bankrecht, 14.

Westerman, D. and Hermann, R., 1999. Sachenrecht in Europa. Ed. Ch. v. Bar, Bd. 1. Osnabrück.

Wieling, H., 2001. Sachenrecht. Trier.

Wolfsteiner, H. and Stöcker, O., 1998. Nicht-akzessorisches Grundpfand für Mitteleuropa. $Z B B, 4$.

Wołodkiewicz, W. and Zabłocka, M., 2005. Prawo rzymskie, instytucje. Warszawa.

\section{Информация об авторе / Information about the author}

Вударски Аркадиуш, профессор польского и европейского частного права и сравнительного права Европейского университета Виадрина (Германия, г. Франкфурт-на-Одере); заведующий кафедрой гражданского права, гражданского процесса и сравнительного частного права Зеленогурского университета (Помьша, г. Зелена-Гура)

Arkadiusz Wudarski, Professor of Polish and European Private Law and Comparative Law, European University Viadrina (Frankfurt am Oder, Germany); Head of the Civil Law, Civil Procedure and Comparative Private Law Department, University of Zielona Góra (Zielona Góra, Poland).

E-mail: wudarski@europa-uni.de; сайт в Интернете: www.wudarski.eu

Дата поступления рукописи в редакцию издания: 25.11.2020; дата принятия статьи к опубликованию: 02.02.2021.

Submitted 25.11.2020; revised 02.02.2021. 